\title{
INTERNATIONAL CONFERENCE SAFE AND SECURE SOCIETY 2021
}

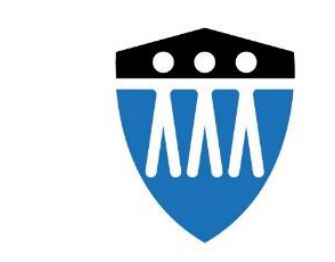

BEZPEČNÁ SPOLEČNOST

2021

Ceske Budejovice, October 12. - 13., 2021

Czech Republic

CONFERENCE PROCEEDINGS

Ceske Budejovice 2021

College of European and Regional Studies

Department of Law and Security Studies

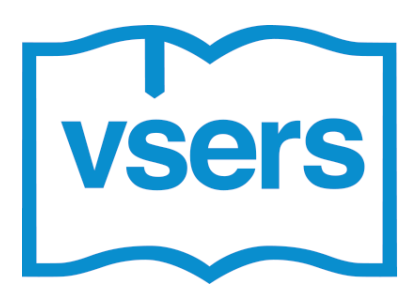




\section{Publisher:}

College of European and Regional Studies

Czech Republic

\section{Edited by:}

PhDr. Štěpán Kavan, Ph.D.

\section{Reviewed by:}

doc. Ing. Jiří Pokorný, Ph.D., MPA

Faculty of Safety Engineering VSB - Technical University of Ostrava, Czech Republic

doc. Ing. Alena Oulehlová, Ph.D.

Faculty of Military Leadership University of Defence, Czech Republic

Individual papers were reviewed by external reviewers.

\section{Citation example:}

AUTHOR, A. Title of paper. In Kavan, Š. (eds.) International Conference Safe and Secure Society 2021. Conference proceeding. Ceske Budějovice: College of European and Regional Studies, Czech Republic, 2021. pp. 15 - 23. DOI: 10.36682/SSS_2021. ISBN je 978-80-7556-097-1, ISSN 2533-6223.

Publication is not a subject of language check. Authors are fully responsible for the content and originality of the articles.

C 2021 Vysoká škola evropských a regionálních studií

DOI 10.36682/SSS_2021

ISBN 978-80-7556-097-1

ISSN 2533-6223 (online: www.icsss.eu) 


\section{PROGRAMME AND SCIENTIFIC COMMITTEE}

Denis K. Alexeev

Russian State Hydrometeorological University, Saint Petersburg

Russian Federation

\section{Benoît Flamant}

Fire Rescue Service of Savoy Department

France

\section{Tom Børsen}

Center for Applied Ethics and Philisophy of Science, Aalborg

Denmark

\section{George Boustras}

European University Cyprus, Nicosia

Cyprus

\section{Lenka Brumarová}

Faculty of Safety Engineering, VŠB - Technical University of Ostrava

Czech Republic

\section{Lubomír Bureš}

Fire Rescue Service of South Bohemia

Czech Republic

\section{Leonor Calvo}

Department of Biodiversity and Environment Management

University of Leon

Spain

\section{Andrea Čajková}

Faculty of Social Sciences, University of Saints Cyril and Methodius

Slovak Republic

\section{Jiř́i Dušek}

College of European and Regional Studies

Czech Republic

\section{Igor Goncharenko}

University of Civil Protection, Ministry for Emergency Situations of the Republic of Belarus Republic of Belarus

\section{Zdeněk Hon}

Faculty of Biomedical Engineering, Czech Technical University

Czech Republic

\section{Barbara Juen}

Faculty of Psychology and Sports Science, University of Innsbruck

Austrian Red Cross

Austria

\section{Katharina Anna Kaltenbrunner}

Faculty of Law, Paris Lodron University of Salzburg

Austria

\section{Štěpán Kavan (předseda / chairman)}

Fire Rescue Service of South Bohemia

Faculty of Health and Social Sciences University of South Bohemia

Czech Republic

\section{Rastislav Kazanský}

Faculty of Political Science and International Relations

Slovak Republic

\section{Želimir Kešetović}

Faculty of Security Studies, Belgrade University, Beograd

Republic of Serbia 


\title{
Nikolaos Lalazisis
}

Center for Security Studies

Greece

\section{Gaston Meskens}

Science and Technology Studies Unit

Nuclear Researcing Centre

Belgium

Lenka Michalcová

Faculty of Transportation Sciences, Czech Technical University in Prague

Czech Republic

Jana Müllerová

Academy of the Police Force in Bratislava

Slovak Republic

\section{Marijana Musladin}

University of Dubrovnik, Dubrovnik

Republic of Croatia

\author{
Alena Oulehlová \\ Faculty of Military Leadership University of Defence \\ Czech Republic
}

\section{Juliusz Piwowarski}

University of Public and Individual Security „Apeiron“ in Cracow

Poland

\section{Jiří Pokorný}

Faculty of Safety Engineering VSB - Technical University of Ostrava

Czech Republic

\section{Peter Smeriga}

University of Mostar, Mostar

Republic of Bosnia and Hercegovina

\section{Marek Smetana}

Faculty of Safety Engineering VŠB - Technical University of Ostrava

Czech Republic

\section{Roman Svatoš}

College of European and Regional Studies

Czech Republic

\section{Jana Šimonová}

Academy of the Police Force in Bratislava

Slovak Republic

\section{Jarmil Valášek}

Population Protection Institute in Lázně Bohdaneč

Czech Republic

\section{Romeu Vicente}

University of Aveiro

Portugal

\section{Ivan Vuković}

Faculty of Political Sciences University of Montenegro, Podgorica

Republic of Montenegro

\section{Vasyl Zaplatynskyi}

National University of Physical Education and Sport of Ukraine

Academy of Safety and Bases of Health,

Ukraine 


\section{CONTENT}

Influence of the concentration of diamond grains on the cutting ability of diamond abrasive tools during emergency response

Babich Vitaly 9

The presence of a neorealistic paradigm in current international security relations

Cséfalvay Juraj, Kazanský Rastislav

Fires in Closed Spaces

Felcan Miroslav

Identification and Evaluation of the Important Objects within a Territory in the Context of a Blackout

Fröhlich Tomáš, Slabý Jiř́í, Hon Zdeněk

Road Safety from the Perspective of European Union

Hudecová Vladimíra. 45

Inpatient Medical Facilities and their Vulnerability

Kabarová Ivana, Danihelka Pavel. 52

Fire Prevention of Municipal Waste Landfills

Kavan Stepan 61

Conceptualization of political extremism and radicalism: An outline of selected theoretical aspects of research

Kazanský Rastislav, Hrubon Anton 68

Practical and Epistemiological Basis for Research into the Security Threats of Terrorism and Radicalization in the Online Space

Kazanský Rastislav, Rysova Lucia, Mijoč Nina 78

Protection of Soft Targets in the Health Sector

Kosáčková Jitka, Havránkova Renata. 
Fire Protection as Part of an E-learning Course on Security Issues at the Faculty of Education of the Charles University

Kovaříková Miroslava, Hřebík František .............................................. 96

Selected Current CBRN Security Issues in the Czech Republic

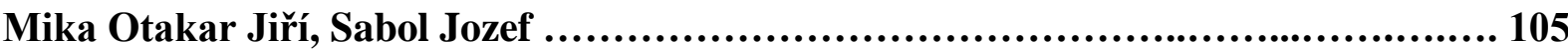

Use of VIN Decoder in Critical Applications of the eCALL Type

Rak Roman, Kopencová Dagmar, Felcan Miroslav, Vlach Frantisek

The impact of non-repayable financial contributions on the progressive

development of the infrastructure of the Fire and Rescue Service

Simonova Jana, Suja Marian

New Trends in Cyber Security

Sulc Vladimir 126 


\section{ÚVOD}

Vážení př́iznivci bezpečnostních věd, opět máme prŕiležitost představit vám sborník prŕspěvků $\quad \mathrm{z}$ mezinárodní konference o bezpečnostních tématech. Navazujeme na tradici předchozích sborníků s př́spěvky, které jsou tematicky zaměřené na problematiku bezpečnosti. I proto jsme museli některé autory odmítnout. Zároveň jsme zpř́ísnili podmínky recenzního ř́zení, což dle našeho přesvědčení vedlo $\mathrm{k}$ dalšímu zvýšení kvality publikovaných článků. Věříme, že $\mathrm{v}$ předložených příspěvcích naleznete odborné pohledy a informace $\mathrm{k}$ tématu bezpečné společnosti v celé její komplexnosti.

Zároveň vám sborník předkládáme jako platformu pro navázání nových pracovních kontaktů, které jsou nezbytné pro další rozvoj bezpečnostní problematiky. Jsme rádi, že publikace z předchozích ročníků konference se těší širokému zájmu. Stejně důležitá je pro nás i míra osobní účasti, která je každoročně vysoká.

Budeme rádi, pokud sborník př́spěvků bude pro vás vzpomínkou na letošní ročník a zároveň pozvánkou na další akce a semináře z oblasti bezpečnosti.

www.icsss.eu

\section{INTRODUCTION}

Dear supporters of security sciences,

We are pleased to introduce you the proceedings from the conference on security and safety issues. We follow up the previous proceedings focused on the topic of security and safety. Therefore we had to refuse some authors. We also made the conditions of review process stricter, which led to increasing quality of published articles, in our opinion. We believe that you will find different views of the topic on safe society in all its complexity, and useful information on it as well.

We also submit the proceedings as a platform for establishing new work contacts which are inevitable for future development of the security issue. We are pleased that the publications from previous conference attract general interest. The number of participants, which is high every year, is important to us as well.

We will be glad if the proceedings is for you a memory of this year's colloquium and also an invitation to other events and seminars on the security issue.

www.icsss.eu/en/
Štěpán Kavan editor 


\title{
Influence of the concentration of diamond grains on the cutting ability of
}

diamond abrasive tools during emergency response

DOI: $10.36682 / S S S \_2021 \_1$

\section{Candidate of Engineering Sciences, Babich Vitaly}

\author{
Deputy Head of the branch "Institute for Retraining Deputy Head of the branch "Institute for \\ and Advanced Studies" Retraining and Professional Development" of \\ University of Civil Protection of the Ministry of the Civil Defense University of Belarus \\ Emergency Situations of Belarus \\ Republic of Belarus, 220118, Minsk Mashinostroiteley 25 \\ E-mail: Babich83@mail.ru
}

\begin{abstract}
Annotation
The influence of diamond grains concentration on the wear mechanism and cutting ability of diamond cutting discs during emergency response was studied. It is shown that reduction of the cutting ability of a wheel is caused by predominant wear of diamond grains and reduction of their number on the surface of the segments rather than by graphitization of diamond grains and transfer of wear products when cutting steel to the surface of composite material
\end{abstract}

\section{Key words}

Diamond wheel, diamond grains wear, wear surfaces, diamond abrasive composites, friction interaction

\section{Introduction}

Diamond abrasive tools have undeniable advantages over abrasive ones, especially when machining hard alloys in combination with steel, concrete, glass. However, when processing cast irons and steels, it is inferior to abrasive in quality, productivity and economic efficiency. It is believed that the low efficiency of diamond abrasive tools is due to the adhesive interaction of the diamond abrasive composite material (diamond grains and binder) with iron and its alloys, which results in the transfer of wear products to the surface of the composite material, as well as graphitization of diamond grains and the termination of the cutting process (Denkena B., 2011, Zakharenko I.P., 1980). In mechanical engineering, the problem of processing steel and cast iron is solved by using a tool with cubic boron nitride on ceramic (polymer) bonds (Zou, L, 2013, Lane B.M., 2010).

Cubic boron nitride and ceramic binder interact to a lesser extent with iron than diamond, which reduces the transfer of wear products to the surface of the composite material (grains of cubic boron nitride and binder). There are a number of areas (cutting large steel structures, highly reinforced concrete structures, etc.) where diamond abrasive tools can be an alternative to abrasive ones due to their low dimensional resistance and low strength. Such a specialized tool is developed taking into account the reduction of the effects of contact interaction of the composite material with steel, by replacing part of the diamond grains with cubic boron nitride and the introduction of components $\left(\mathrm{ZnO}_{2}, \mathrm{Al}_{2} \mathrm{O}_{3}\right.$, WC, etc.) into the binder that prevent its adhesive interaction with steel (Loginov P.A.,2013).

The concentration of cutting elements (grains of diamond cubic boron nitride) in such composite materials is 50, 75 rel. \% (12.5; 19 vol.\%), And in abrasives - 200, 250 rel. \% (50, 60 vol.\%) $\mathrm{Al}_{2} \mathrm{O}_{3}, \mathrm{SiC}$ (Loladze TN, 2002, Loladze TN, 1972). An increase in the concentration of cutting elements in the bond changes the structure of the composite material. The structure of a diamond-abrasive material with 75 rel. \% of diamond grains is a matrix of a binder in which diamond grains are located, and abrasive grains of abrasive (corundum, silicon carbide, etc.), united by interlayers of the binder. It is obvious that 
an increase in the concentration of diamond grains in a composite material, as well as the resulting changes in its structure, can change the conditions of contact interaction of the composite material with steel.

The paper studies the effect of the concentration of diamond grains on the cutting ability of diamond abrasive tools. The objects of study were diamond cutting wheels (IARI $300 \times 3 \times 40$ ) with a concentration of diamond grains (AC200, 500-400 microns) in a composite material (segment of a circle) 50, 100, 125 rel\%.

A plate of steel grade St45 was cut in circles into blanks with dimensions of 100x10x10. Wheel rotation speed $3000 \mathrm{rpm}$. The pressing force of the wheel to the workpiece was $40 \mathrm{~N}$. An abrasive wheel (230x4x32 13A F46 T2B4) was used as a reference sample.

\section{Experimental Results and their Discussion}

Cutting capacity of a wheel with a diamond grain concentration of 50 rel. \% changes with an increase in the number of cuts from 2 to 4,6 and from 6.4 to 5.1 and $3.9 \mathrm{~g} / \mathrm{min}$, respectively. Changes in the cutting ability of wheels from $100 \mathrm{rel} . \%$ and $125 \mathrm{rel} . \%$ by the concentration of diamond grains in the composite material from the number of cuts is expressed to a lesser extent: the cutting ability of the wheels was $11.2 ; 9.4 ; 7.7 \mathrm{~g} / \mathrm{min}$ and $16.8 ; 15.5 ; 14.7 \mathrm{~g} / \mathrm{min}$ for $2,4,6$ cuts, respectively. The cutting ability of the abrasive wheel after $2,4,6$ cuts was $22.3 ; 21.2 ; 19.7 \mathrm{~g} / \mathrm{min}$, respectively.

The morphology of the wear surface of steel after processing with diamond-abrasive and abrasive wheels is a set of smooth areas between which grooves are located, ridges with flat rounded tops oriented in the direction of processing against which particles of wear products of steel and composite materials are located (Fig. 1). Reliefs on the wear surfaces of steel formed by diamond abrasive wheels with 50 and 100 rel. \% concentration of diamond grains in the composite material differ from the reliefs formed by an abrasive and diamond-abrasive wheel with 125 rel. \% concentration of diamond grains in the composite material.

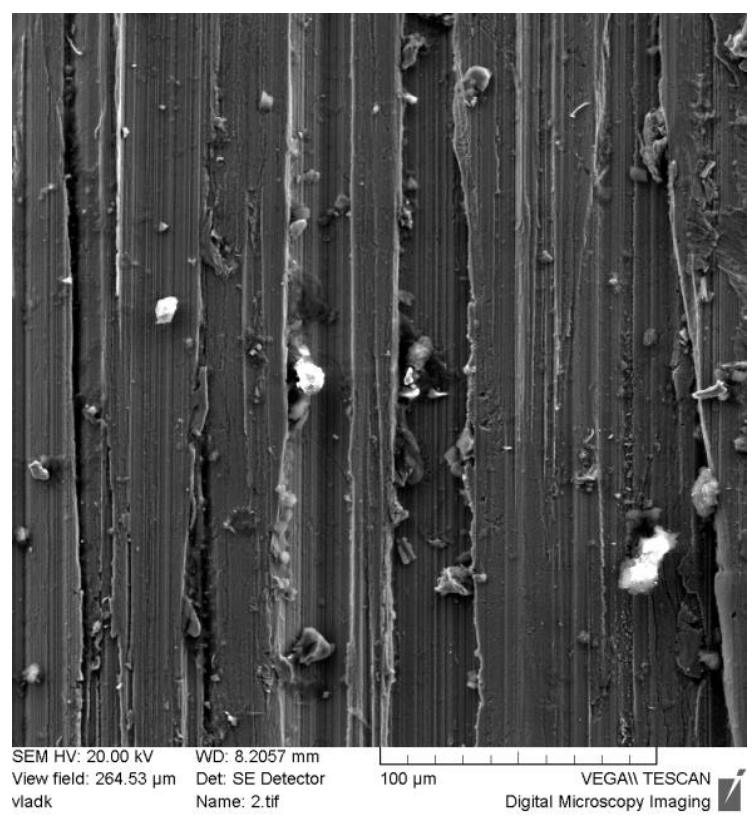

$\mathrm{a}$

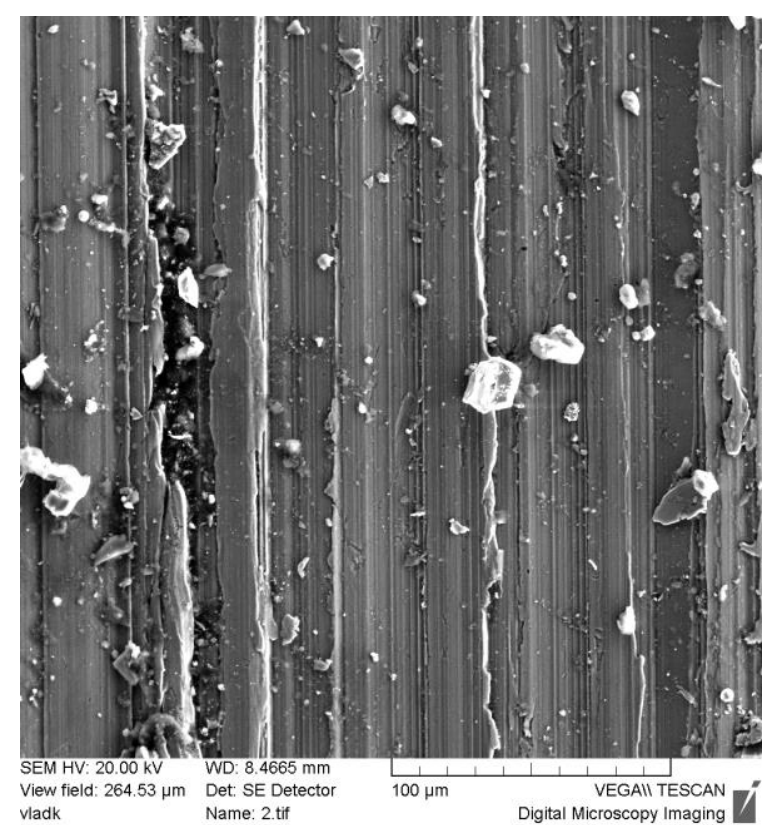

b 

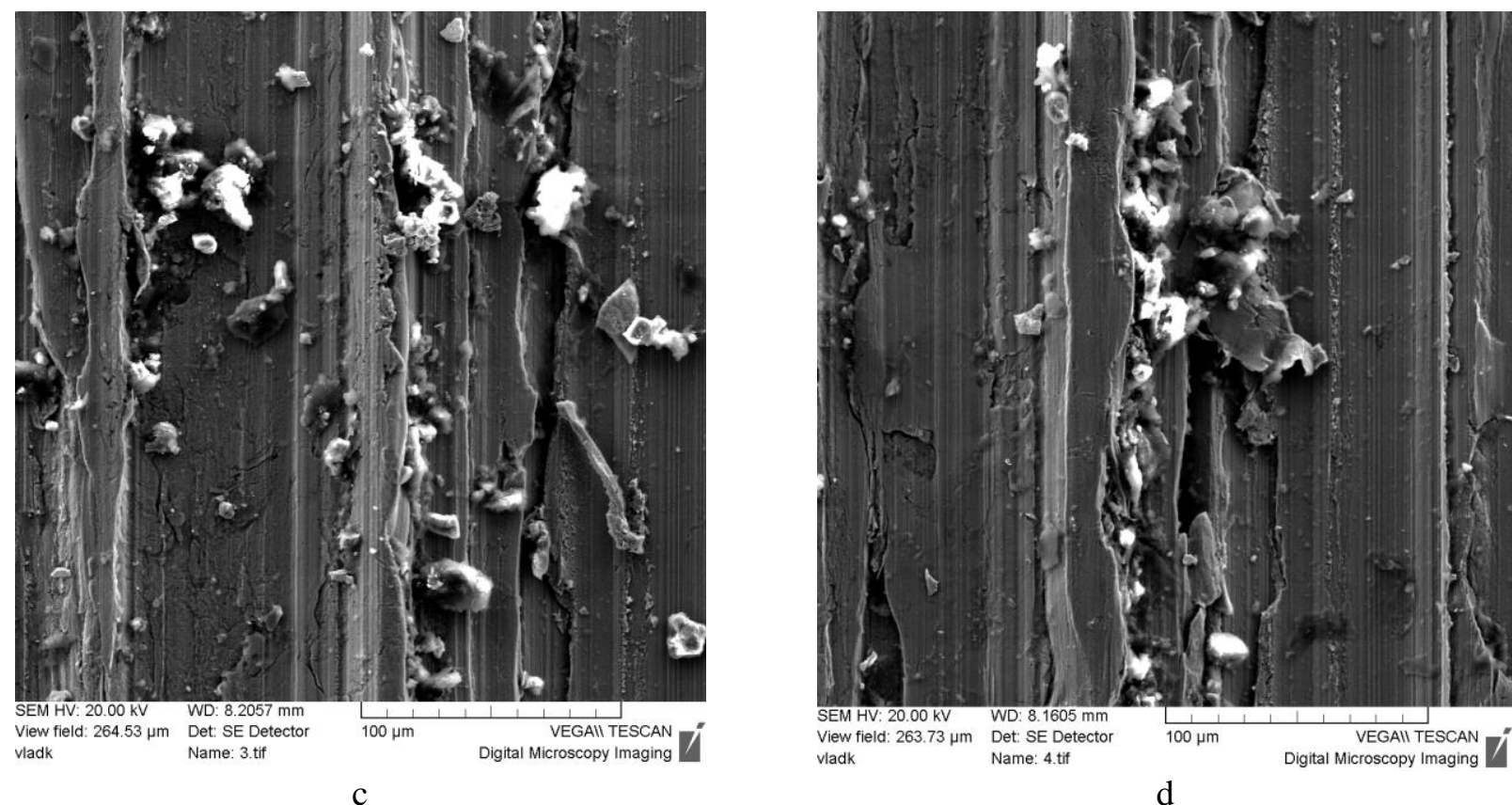

$a, b, c$ - the concentration of diamond grains in the composite material 50, 100, $125 \mathrm{rel} . \%$, respectively

Rice. 1. Morphology of the wear surface of steel after processing with diamond abrasive $(a, b, c)$ and abrasive wheels $(d)$

The grooves are less pronounced in relief, the particles of wear products are smaller, wider, and there are more flat areas (Fig. 1 a, c, d). The morphology of wear surfaces of diamond-abrasive composite materials with 50,100,125 rel. \% concentration of diamond grains represent a bunch with grooves and ridges oriented in the direction of processing against which diamond grains and particles of steel wear products are located in the form of island films. The presence of these particles was noted only on separate segments of the circles, both on the bond surface and on diamond grains. Differences in the morphology of the wear surfaces of composite materials are manifested in the number of diamond grains in the bond, their shape and size (Fig. $2 \mathrm{a}, \mathrm{b}, \mathrm{c}$ ).

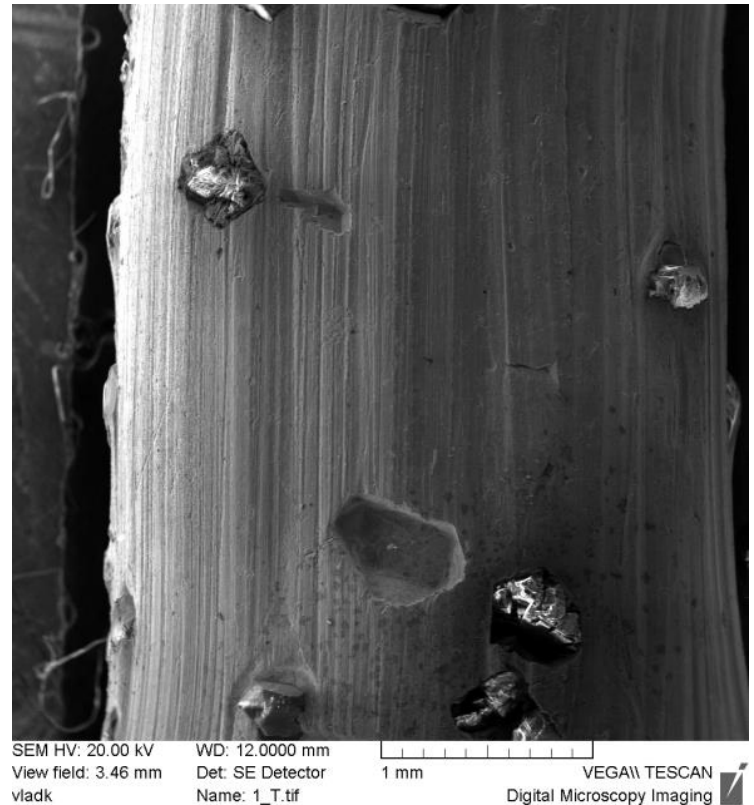

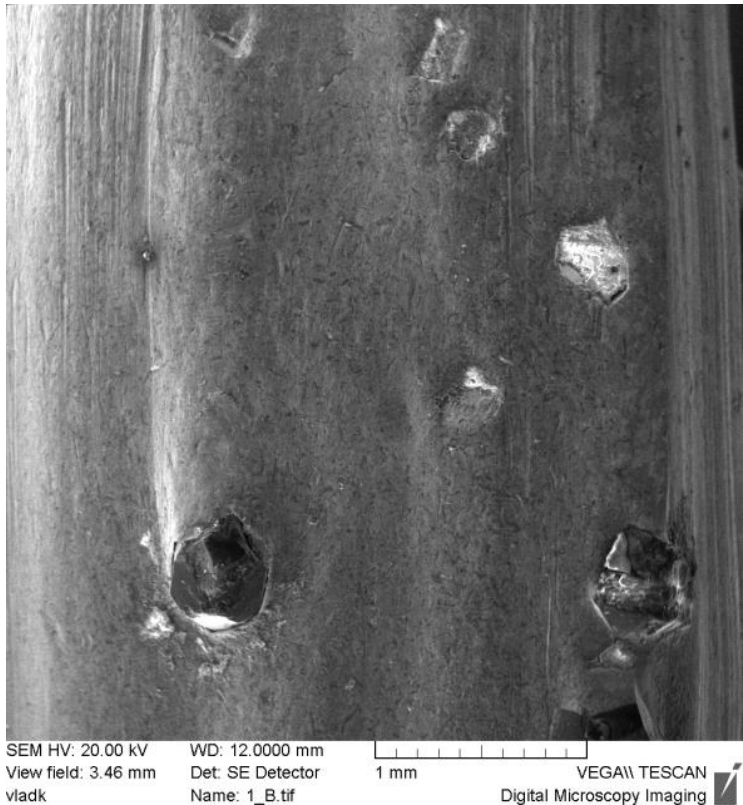

$\mathrm{b}$ 


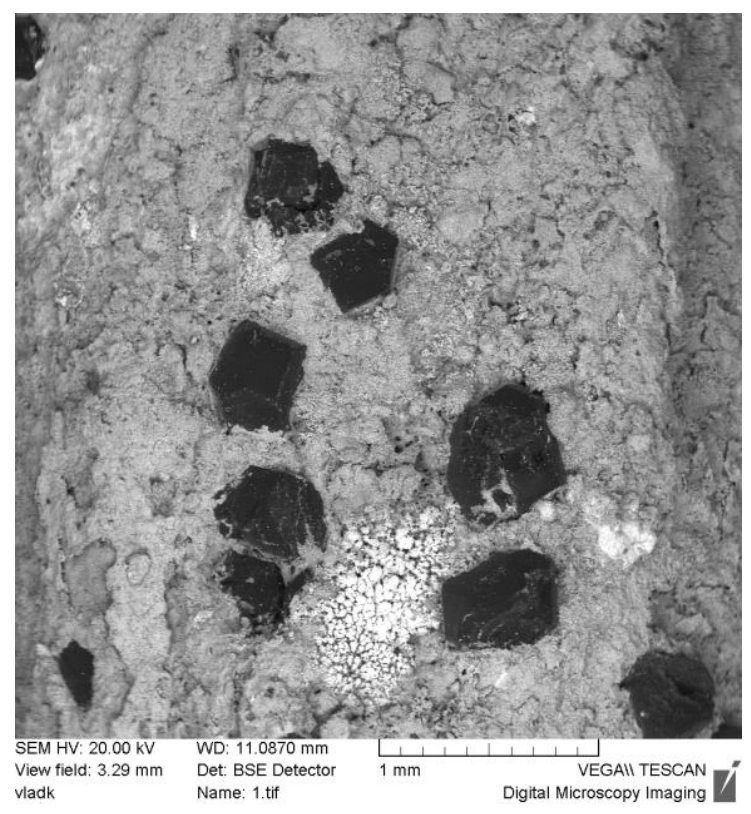

d

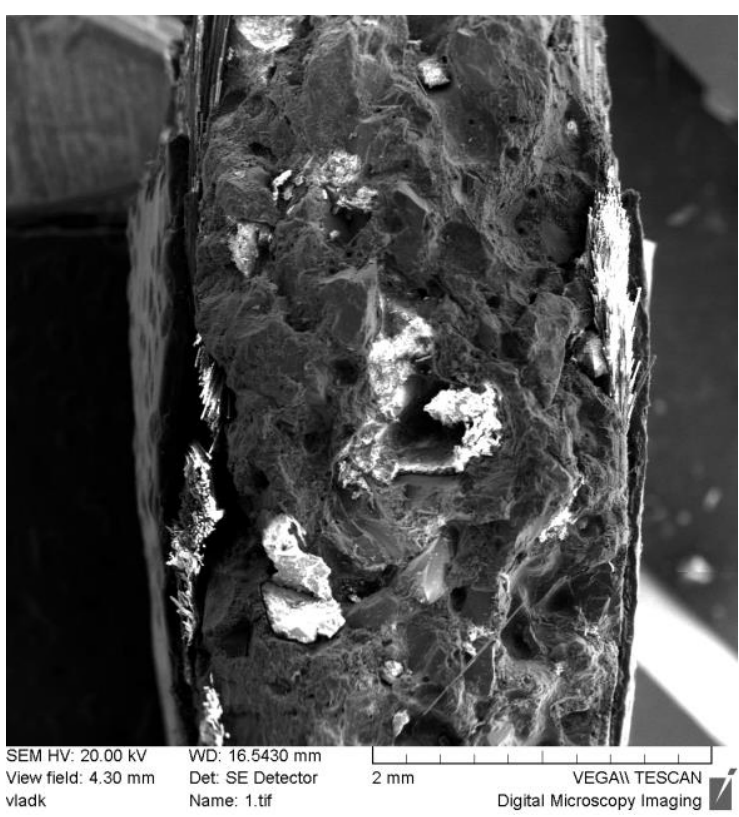

d

$a, b, c$ - concentration of diamond grains in composite materials with 50,100, 125 rel. \%, respectively Rice. 2. Morphology of wear surfaces of diamond-abrasive $(a, b, c)$ and abrasive $(d)$ composite materials after 6 cuts

The morphology of the wear surface of an abrasive composite material is represented by a set of different sizes of protrusions and depressions. The protrusions are the tops of whole or cleaved abrasive grains, and the depressions are sections of the bond, including in the form of imprints from torn out and fragments of destroyed abrasive grains (Fig. 2d).

Differences in the morphology of wear surfaces of diamond-abrasive composite materials with 50,100, and 125 rel. \% concentration of diamond grains, namely, their number, shape, size of diamond grains show that changes in their concentration in the composite material affect the conditions of contact interaction in the composite material - steel system.

On the wear surface of the composite material with 50 rel. \% concentration of diamond grains, most of the grains are destroyed by main cracks and are agglomerates of several fragments, on the surface of the matrix there is a relief of grooves and ridges with rounded tops and island films of glass wear products. On the wear surface of composite materials with 100 and 125 rel. \% concentration of diamond grains, the number of diamond grains on the surface is more, broken into several fragments (agglomerates) is less, the grain size is larger (Fig. 2 b, c). Diamond grains on the wear surface of a composite material with 125 rel. \% concentration of diamond grains, protrude above the bond to a lesser extent than in composite materials with 50 and 100 rel. \% concentration of diamond grains in the composite material, wear areas are formed on their surface (Fig. 2). Differences in the morphology of the wear surface of composite materials with 50,100,125 rel. \% concentration of diamond grains can be associated with different load on the grains. The greatest load on diamond grains will take place in a composite material with 50 rel. \% concentration of diamond grains, the smallest - in the composite material with 125 rel. \% concentration of diamond grains. The surface morphology of diamond grains in a composite material shows that the main mechanism of their wear is brittle fracture. The wear of composite materials with 50 and 100 rel\% concentration of diamond grains occurs due to brittle fracture of diamond grains and wear of the binder. However, regardless of the concentration of diamond grains, the wear of composite materials during steel processing does not occur in the so-called "self-sharpening" mode, in which the rate of bond wear correlates with the wear rate of diamond grains, ensuring the protrusion of lower grains from the bond (Loladze TN, 2002, Loladze TN, 1972). The morphology of the wear surfaces of composite materials with 50 and 100 rel\% concentration of diamond grains shows that the wear of the binder proceeds at an intensity insufficient to expose the unworn grains lying on the binder surface. In a composite material with 125 rel. \% concentration of diamond grains, the wear of the binder proceeds 
less intensively than in composite materials with a lower concentration of diamond grains, however, wear (destruction) of diamond grains is less pronounced: the wear areas of diamond grains are formed by multiple cleavages of small particles (Fig. 2c).

Thus, an increase in the concentration of diamond grains in the composite material reduces the load on the grains and reduces the nature of their wear. The wear of diamond grains in the composite material occurs as a result of multiple chips and the formation of small (5-20 microns) fragments, rather than the destruction of grains into several (2-3) parts by main cracks. The consequence of this is a higher cutting capacity of the composite material (diamond wheel) from 125 rel. \% concentration of diamond grains. However, the wear of diamond grains by the brittle fracture mechanism indicates the dynamic, impact nature of the interaction of the composite material with steel and is typical for the processing of brittle materials (granite, concrete, etc.), and not plastic ones (steel, aluminum, etc.) ... Wear (of steel) during abrasive (diamond abrasive) processing is considered in the model of multiple cutting with sharp edges (blades) of a single tool (grain). However, in diamond abrasive and abrasive tools, the grains are located randomly and are not oriented by sharp edges (edges, tops) to the surface to be treated.

Both flat and sharp peaks and edges of diamond grains, as well as the bond, come into contact with the surface. Therefore, wear during diamond abrasive machining can be considered, inter alia, as frictional contact interaction of two surfaces, the prevailing mechanism of which is the dispersion of the surface layer into fragments by single tools, which also has a frictional component (Loladze TN, 2002, Loladze TN, 1972). Regardless of the concentration of diamond grains in the composite material and the type of tool, wear surfaces of steel formed by them contain round-shaped wear products, some of which are morphologically related to the surface (Fig. 1). The shape of the wear products shows that their formation occurs at temperatures close to the melting temperature of the steel (both large and lower). An increase in temperature in the zone of contact interaction changes the mechanical characteristics of the near-surface layer of steel: its hardness decreases, and its plasticity increases. The flat tops of diamond grains also enter the "cutting" process: this is indicated by the values $(19.7 \mathrm{~g} / \mathrm{min})$ of the cutting ability of the composite material and the morphology of the wear surface of the steel (Fig. 1). The tops of diamond grains (including flat ones) deform the plastic (quasi-liquid) near-surface layer of steel, move and push part of it out of the frictional contact zone, forming characteristic surface microcracks in the form of alternating flat areas, ridges with rounded tops, grooves with beads at the edges (Fig. . $1 \mathrm{a}, \mathrm{b}, \mathrm{c}$ ). A similar morphology of the wear surface is also formed when steel is machined with an abrasive tool (Fig. 1d).

However, in contrast to diamond abrasive tools, abrasive tool wear proceeds in a mode similar to the "self-sharpening" mode: abrasive grains are destroyed by multiple chips and crumble or break out of the bond. The high (250 rel.\%) Concentration of abrasive grains in the composite material neutralizes the effect of the bond (with low hardness and strength) on the process of their frictional interaction with the steel surface.

As a result, on the surface of the abrasive wheel, in a certain area of cutting conditions, a developed bumpy relief is formed and exists, providing a constant value of the cutting ability. A slight decrease in the cutting ability of the abrasive wheel with an increase in the number of cuts is associated with the wear of its side surfaces.

The conditions for the frictional contact of the diamond-abrasive composite material with steel are optimal for the development of adhesion and tribochemical interaction of diamond with steel. In this case, on the surface of diamond grains, one should expect the formation of flat wear areas with bumpy microrelief and films of iron wear products (Lane BM, 2010). However, microreliefs formed on the surface of diamond grains have all morphological features characteristic of brittle fracture; island films of steel wear products are present only on the surface of individual grains (Fig. 2 a). The formation of such microreliefs on the diamond surface cannot be explained by its destruction due to repeated cycles of adhesive setting with iron and the subsequent removal of iron films from the surface: on the surface of diamond grains, only individual island films of steel wear products are present. The nature of the change in the cutting ability of composite materials with different concentrations of diamond grains, the 
morphology of the wear surfaces of composite materials shows that the brittle fracture of diamond grains is preceded by a stage of fatigue failure. Repeated cycles of diamond grain penetration into steel, accompanied by an increase in temperature, reduce the hardness of the diamond. In the temperature range 1275 - $1675 \mathrm{~K}$, the hardness of diamond is 4-2 GPa (Kruglov GA,1977, PWButler-Smith, 2011). A decrease in the hardness of the near-surface layer on diamond grains promotes the initiation of microcracks, then the formation of a network of microcracks (damaged layer). The destruction of grain, depending on the power parameters of processing, occurs by multiple chips,

Thus, brittle fracture is the leading wear mechanism for diamond grains, and the adhesion wear mechanism is concomitant.

The adhesive wear mechanism is the leading one during bond wear, despite the presence of scratches (grooves) on its surface oriented in the processing direction, characteristic signs of the abrasive wear mechanism. However, scratches on the bond surface are formed under the action of steel wear products on the composite material surface (Fig. $1 \mathrm{a}, \mathrm{b}, \mathrm{c}$ ). Therefore, the adhesive wear mechanism, being the leading one in bond wear, is also the leading wear mechanism of the composite material as a whole. An increase in the concentration of diamond grains in the composite material negates the effect of the adhesive wear mechanism on the cutting ability of the composite material and makes it possible to develop a specialized diamond-abrasive tool for steel processing.

\section{Conclusions}

Cutting steel with abrasive and diamond-abrasive wheels has a number of common features: single tools are grains (corundum, diamond) with sharp and flat tops; the cutting process is accompanied by frictional interaction of surfaces and an increase in temperature in the cutting zone (frictional contact). An increase in the concentration of diamond grains in the composite material reduces the frictional component of the cutting process, the load on the grains, which increases the cutting ability of the wheel. This shows that there is no fundamental limitation on the use of diamond grains in abrasive tools for machining steel. Cutting capacity of diamond abrasive wheel from 125 rel. \% concentration of diamond grains slightly differs from the cutting ability of abrasive.

\section{Literature}

DENKENA, B. et al., (2011). Wire Cutting Tool Concepts for Steel Machining / Advanced Materials Research, Vol. 325, pp. 238-243, 2011.

KRUGLOV GA, TARASEVICH I., K., (1977). Ways of intensification. diamond processing. In the book: Synthetic diamonds - the key to technical progress, hP, Kiev: Nauk.dumka. pp. 132-136.

LANE B., M., SHI M., DOW TA SCATTERGOOD, R., (2010) Diamond tool wear when machining Al6061 and 1215 steel // Wear. Vol. 268 . pp. 1434-1441.

LOGINOV, P., A., LEVASHOV, E., A., KURBATKINA, V., V., ZAITSEV, A., Z., SIDORENKO, D., A., RUPASOV S., I., (2013). Features of pressing and sintering of a mechanically doped refractory alloy $\mathrm{Cu}-\mathrm{Fe}-\mathrm{Co}-\mathrm{Ni}$, dispersion-strengthened by $\mathrm{WC}$ and $\mathrm{ZrO} 2$ nanoparticles. // III-rd All-Russian youth school-conference "Modern problems of metal science": Collection of works, Pitsunda, Abkhazia, September 10-13, 2013, Ed. House MISiS, 2013. pp. 112-123.

LOLADZE, T., N., BOKUCHAVA, G., V. (1972). Worn diamond wheels. - M. Metallurgy, 543 p.

LOLADZE, T., N. (2002) Cutting forces when grinding metals // Metalworking. No. 1. pp. 38.

BUTLER-SMITH, P., W., DAAXINTE, M. DAINE, (2011). Ordereddiamondmicro-arraysfor ultraprecisiongrinding - an evaluationinTi - 6Al - 4V, Int. J.Mach.Tools Manuf. 51 (1) (2011) 54-66.

ZAKHARENKO I., P., (1980). Diamond tools and machining processes. Kiev: Technique, p. 215.

ZOU, L., DONG, G., J.; ZHOU, M. (2013). Investigation on frictional wear of single crystal diamond against ferrous metals. Int. J. Refract. Met. Hard Mater. 41, 174-179. 
DOI: 10.36682/SSS_2021_2

\author{
Mgr. Juraj Cséfalvay, MBA \\ Department of Security Studies Department of Security Studies \\ Faculty of Political Science and International The Faculty of Political Science and International \\ Matej Bel University Matej Bel University \\ $\triangle$ Kuzmányho 1, 974 01, Banská Bystrica, Slovak republic \\ Email: csgeorgesk@gmail.com \\ doc. PhDr. Rastislav Kazanský, PhD., MBA \\ Department of Security Studies Department of Security Studies \\ Faculty of Political Science and International The Faculty of Political Science and International \\ Matej Bel University Matej Bel University \\ $\triangle$ Kuzmányho 1, 974 01, Banská Bystrica, Slovak republic \\ Email: rastislav.kazansky@umb.sk
}

\begin{abstract}
Annotation
The collapse of the bipolar world order in the 1990s provided an opportunity for the United States to gain a dominant position as a global security player. The paradigm of realism and neorelism, which were characteristic for maintaining security in the bipolar world, seemed useless by its disintegration. The state, as a key security player, despite the diverse prevailing security paradigm, will always play a primary role in ensuring security of the population, territorial integrity and sovereignty. The reason for this premise is that a relatively functioning international system still prevails at the international level, compliant to an acceptable extent of international law and recognizing the sovereignty, territorial integrity and legal equality of states. Due to the foreign policy direction of key security actors in the world, which are eg the Russian Federation, or the United States of America, a realistic security paradigm remains to be as an important research tool for understanding the decisions made by these actors in various situations. Methods of description, content and comparative analysis of used sources were applied to investigate the presented issue.
\end{abstract}

\title{
Key words
}

Realism, neorealism, international security relations.

\section{Introduction}

At present, there is no single world power with the capabilities and declared intention to ensure the unilateral global security of humanity. Despite the technological progress of the world, economic prosperity and the relative well-being of mankind, it is not expected that such a power will be able to establish itself on the international stage in the near future, given the opposing determinants of world globalization, regionalism and the constant efforts of state actors to maintain and increase power balance.

The collapse of the bipolar world order in the 1990s provided an opportunity for the United States to gain a dominant position as a global security player. For the study of the security of a state actor, the analysis of the regional security environment is currently preferred in order to maintain the relevant level of analysis. The paradigm of realism provides an opportunity to determine the factual state of power balance, ie the state that prevails and not which will prevail (Tarasovič et al., 2004). 
Recent conflicts in the world point to the still great importance of military force for the security of the state. The world has changed into a multipolar system and the selected actors are intensively promoting their interests in the form of proxy wars. The end of bipolarity was to bring about an end to the conflict that could have caused World War III. The paradox, however, is that the rate of local armed conflict is the highest since the collapse of bipolarity, and topics such as deterrence and the role of nuclear weapons are re-emerging. (Jurčák, Trebula, 2017).

\section{Theoretical basis for the study of the security paradigm}

The meaning of the word paradigm can most generally be established as a specific pattern or model that may be the result of spontaneous change, steady development, or multiple competing currents. However paradigm has been / is / will be created, it can be stated that such a process can be lengthy or otherwise determined in an extremely short time. Paradigms should help us understand the nature of international relations, how they affect or may affect e.g. to the development of security in a certain time and space. Figuratively speaking, they should help as scientific glasses, through which we perceive many indicators of world events and events in the immediate (local) vicinity.

During the 20th century, several fundamental paradigms of security were created:

- national security, which presupposes a threat to the state by other states, seeks to preserve its own independence and sovereignty, and the state is the highest value that requires protection,

- international security, which is the result of the Caribbean crisis, when the great powers were on the brink of nuclear war and the crisis showed how far the actors are willing to go (the reference object was the state),

- regional securitywhich reflects e.g. theory of security complexes,

- global security, where the provision of common security prevails, overcomes the security dilemma, includes not only ensuring the security of states, but also non-state actors,

- human security, when the essence is the protection of the individual, his life and rights.

This development is also shown in more detail on the timeline, see Figure no. 1 (Belan, 2015).

Among some significant paradigm changes in international security we can include e.g. the collapse of bipolarity in the 1990s as a result of rival currents, al-Qaeda's terrorist attack on the US in 2001 and subsequent international international crisis management military operations over the next twenty years as a result of steady development, protests during the so-called Arab Spring 2010-2010, the act of annexation of Crimea by the forces and resources of the Russian Federation (RU) in 2014 or the conclusion of a joint defense agreement between the United Kingdom of Great Britain and Northern Ireland (Great Britain), the US and the Commonwealth of Australia (Australia) in September of this year. year as a result of spontaneous changes. There would be many more examples, but the above paradigms of the last three decades have had and will continue to have a major impact on security developments at local, international,

In determining the security paradigm, it is proven to use established theories in international relations as methodological tools. SM Walt (1991) divides these into four paradigms: realism, liberalism, social constructivism, and critical theory. All these paradigms provide the essence of examining the paradigm of security in the international environment (Lasicová, Ušiak, 2012). In this case, the term paradigm refers to a theoretical and methodological concept that provides a particular research school with a focus on defining the most crucial questions and principles that should determine the study of selected topics. In this context, it is therefore possible to establish that the dividing line between realism and liberalism is the relationship to power. Idealists are trying to find an answer to

The state, as a key security player, despite the diverse existing security paradigm, will always play a primary role in ensuring the security of the population, territorial integrity, integrity and sovereignty. The behavior of individual states is determined mainly by their size. Small and medium-sized states at the expense of e.g. they integrate independence in decision-making into alliances, large states use their own power potential (Ušiak, Nečas, Dolinec, 2011). Depending on the position of the state at the international level, it has a direct impact on the causes of wars and conflicts. Security and peace are only possible if the sovereignty, independence and territorial integrity of states are recognized at international 
level. (Ušiak, Nečas, 2010). At the legal level, these are the features of the state, which are: territory, population, state power and sovereignty, ie sovereignty (Cibulka et al. 2017).

\section{Picture 1: The security paradigm}

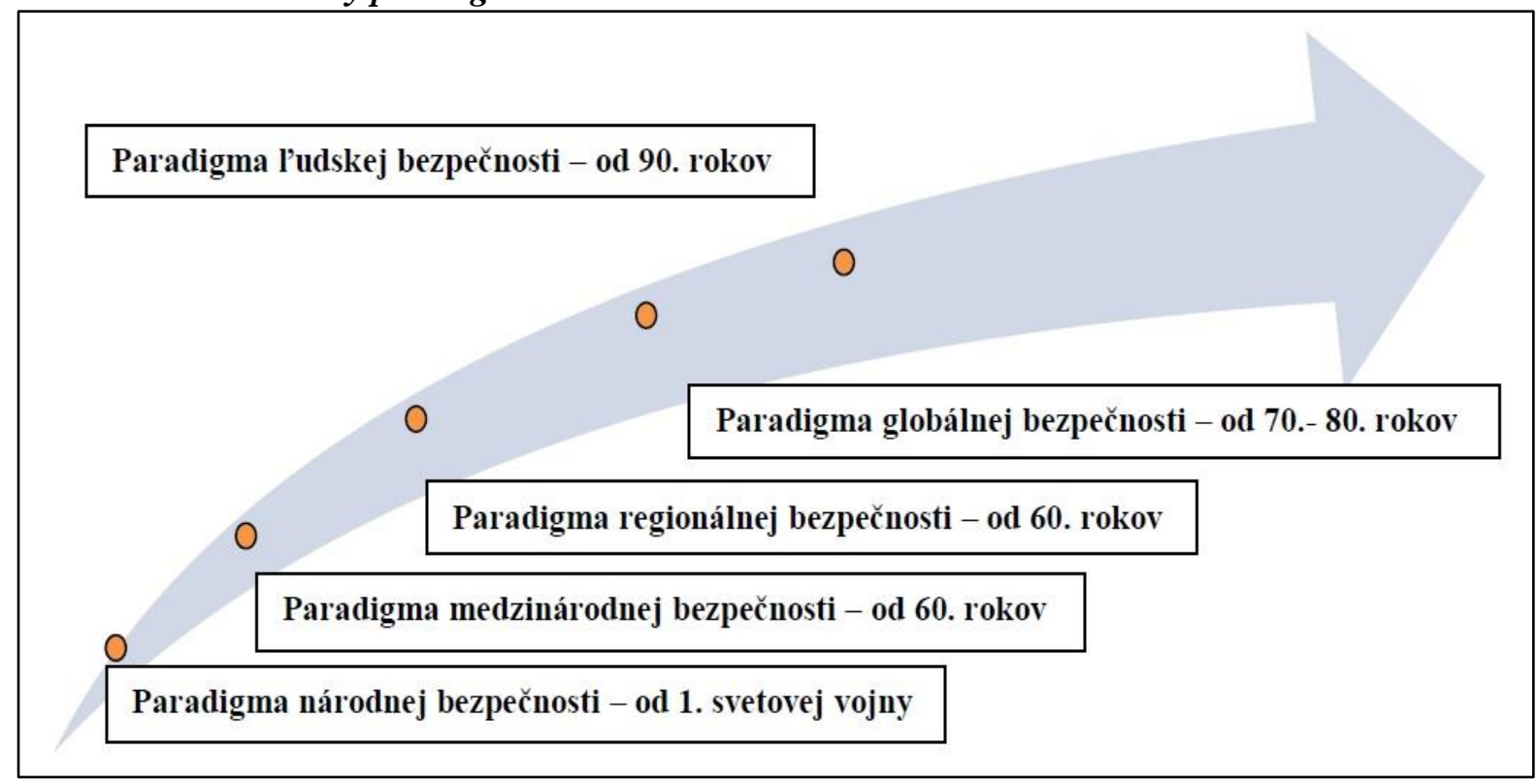

Source: Belan, 2015.

The reason why the state fulfills and probably will have to play the role of a decisive security actor within the security paradigm while maintaining the security of the population, territorial integrity, integrity and sovereignty is that humanity has not been able to exist without conflict since time immemorial. This condition is endemic to human beings to a greater or lesser extent. From a positivist point of view, conflict is necessary to ensure the development of human society, when after reaching the so-called deadlock on the escalation curve of the conflict, in principle, comes a period of change in the form when the new state will never be equal to the state from before the conflict began.

The causes of conflicts are various, such as based on human or group behavior, political reasons, competition for natural resources, ethnic origin, religious reasons or based on structural laws. In examining the causes of conflicts based on structural laws, it is possible to take into account the domestic regime of the state, the defense of the state or the balance of power. Within the paradigm of security at the level of realism, the balance of power is a fundamental factor in the position of the state determining the provision of security (Kazanský, Ivančík, 2015).

The security paradigm can be divided into different levels, such as: global, regional, local, system, subsystem, unit or sector. This division continues to legitimize the classical state-centered security theory with an emphasis on the military and political sector (Lasicová, 2006).

As mentioned in the above texts, the state represents and probably will continue to play a key role as a key security actor in international security relations in the medium term. The reason for this premise is that a relatively functioning international system still prevails at the international level, accepting to some extent international law and recognizing the sovereignty, territorial integrity, legal equality of states and, to a greater extent than not, interference in the internal affairs of the state. T. that the application of the paradigm of realism or neorealism provides the most relevant results of the determination of the real state of power balance. This condition is only applicable under the conditions as long as there is some relevance to the acceptance of international law by state actors as Azud (1998) states "International law, in short, is a set of legal rules governing relations between entities that are states and international governmental organizations. Compliance with these rules is ensured by states individually or collectively. " 
The oldest theoretical school of international relations, within which security paradigms have been established, is geopolitics, to which we can also owe the stabilization of political theories such as idealism and realism (Krejčí, 2010). The basis of realism, which arose in the 40s of the last century, is the emphasis on power policy and the pursuit of one's own (state, national) interests.

The initial premise of realism is that the state is a sovereign actor in the international system. In realism, there is no authority over the state in international politics, and relationships are created and maintained in a natural state, ie anarchy. Realism emphasizes the balance of power that, when disturbed, causes conflict (Heywood, 2008). The realistic tradition is based on a reference to Machiavelli's idea, which focuses on the interests and power of his own state (Wais, 2004). Realism is not a world of reform and radical change, but a world of repetition and an emphasis on the continuity of the nature of international politics. The realistic paradigm asserts the view that states are central actors in the international system (Jurčák et al., 2020).

The neorealism that arose in the 1980s is based on the structuralism of the international system, but retains the decisive nature of power. In reality, it is about establishing structures based on the interactions of states, where the balance of power arises from the instinct of survival and power is divided unevenly (Heywood, 2008). Neorealism is based on structuralism and works mainly with the so-called hard indicators of the balance of power between actors (states) such as: geographical distribution of actors, strategic depth of territory, economic and raw material resources, population size, level of capabilities of the armed forces (Eichler, 2017). The paradigm of the division of power in neorealism is formed by the premise that without inequality, disputes could not be settled, so inequality is a natural state.

The three basic assumptions of realism are:

- States and their representatives are decision-makers in the study of international relations,

- a strong difference between the domestic and foreign policy of the state,

- international relations are a struggle for power and peace (Krejčí, 2010).

The basic features of realism include: state centrism, the orientation to survival and the reliance of the state only on oneself.

The theses of neorealism are:

- the most important actors in world politics are states

- the state represents a single actor,

- the state acts rationally,

- national security is a cardinal issue for the state,

- the system determines the behavior of the state (Krejčí, 2010).

The axioms of neorealism are:

- the removal of a weaker state from a subordinate position (efforts to gain parity),

- the continental power must devote more resources to maintaining its status than the maritime power,

- the maritime power encounters a conflict situation when approaching a ground power (Eichler, 2017). 
Picture 2: Differences between $U S$ and $R U$ from the point of view of neorealism (note $R F=R U$ )

\begin{tabular}{|c|c|c|c|c|c|c|}
\hline & $\begin{array}{l}\text { Mocenský } \\
\text { status }\end{array}$ & $\begin{array}{l}\text { Geopolitické } \\
\text { postavení }\end{array}$ & $\begin{array}{l}\text { Ekonomické } \\
\text { postavení }\end{array}$ & $\begin{array}{l}\text { Způsob } \\
\text { vyvažování }\end{array}$ & $\begin{array}{l}\text { Způsob vyzbro- } \\
\text { jování }\end{array}$ & $\begin{array}{l}\text { Vojenské } \\
\text { postavení }\end{array}$ \\
\hline US & Námořní & $\begin{array}{l}\text { Expanze: } \\
\text { vojenské jed- } \\
\text { notky USA se } \\
\text { po roce } 1990 \\
\text { posunuly o dal- } \\
\text { ších } 1000 \mathrm{~km} \\
\text { na východ }\end{array}$ & $\begin{array}{l}\text { Nadřazenost } \\
\text { USA mají mno- } \\
\text { hem vyšší HDP } \\
\text { a také inovační } \\
\text { kulturu }\end{array}$ & $\begin{array}{l}\text { Vnější } \\
\text { (zahrnuje } 9 \\
\text { států post- } \\
\text { sovětského } \\
\text { prostoru) }\end{array}$ & $\begin{array}{l}\text { Pozitivní (kvali- } \\
\text { tativní i kvanti- } \\
\text { tativní náskok) }\end{array}$ & $\begin{array}{l}\text { Celkově } \\
\text { nadřazenost } \\
\text { podřadnost } \\
\text { pouze na hra- } \\
\text { nici s RF }\end{array}$ \\
\hline $\mathrm{RF}$ & $\begin{array}{l}\text { Kontinen- } \\
\text { tální }\end{array}$ & $\begin{array}{l}\text { Ústup: RF } \\
\text { vyklidila prostor } \\
\text { o rozloze } 1 \text { mil. } \\
\text { km². Své vojen- } \\
\text { ské jednotky } \\
\text { má na vlastním } \\
\text { území }\end{array}$ & $\begin{array}{l}\text { Podřadnost } \\
\text { RF ve všech } \\
\text { směrech zao- } \\
\text { stává a pouze } \\
\text { dohání ztrátu }\end{array}$ & $\begin{array}{l}\text { Vnitřní, RF } \\
\text { se spoléhá } \\
\text { především } \\
\text { na své } \\
\text { vlastní } \\
\text { zdroje }\end{array}$ & $\begin{array}{l}\text { Negativní (do- } \\
\text { hánění ztráty) }\end{array}$ & 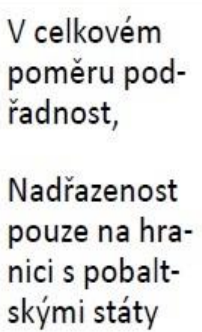 \\
\hline
\end{tabular}

Source: Eichler, 2017.

Realism is a doctrine based on the paradigm of the international system, where anarchism prevails, there is no sovereign institution and conflict is a natural phenomenon. As Jurčák and Trebula (2017) state, "problems of contemporary international securitynoare divided into two basic areas: military and nonmilitary '.. Conflict is an inherent part of human existence, and every state actually has a genome of behavior with more or less aggression, the aim of which is to protect its own interest. Without an understanding of the importance of the state as a decisive security actor in international relations, it is not possible to correctly understand the many ongoing conflicts in the international system.

\section{Neorealism in the form of balancing the influence of US and RU}

Given the foreign policy direction of key security actors in the world, which are e.g. RU or US, the realistic security paradigm remains an important research tool for understanding the decisions that these actors have applied in situations such as annexation of Crimea by the Russian Federation or the conclusion of a defense agreement between the US, Great Britain and Australia (so-called AUKUS). In the case of the annexation of Crimea, the idea has emerged that the continent of Europe can enjoy the status quo of sovereignty without threat, as was the case during the Cold War and other historical conflicts and wars that took place on the European continent.

In the context of the development of bilateral relations between the US and the RU after the end of the Cold War, it can be stated that the US has continuously strengthened its superior position as a naval power over the RU, which is a continental power. From this point of view, the US had and will have the advantage of being far from its opponents and from the place of possible confrontation in the military field. The US is more or less invulnerable and can lead a peaceful life despite the conduct of proxy wars, the military can focus more on the development of naval capabilities (eg aircraft carriers, expeditionary forces, long-distance projection), are not dependent on close allied pacts, and they can use the potential of their potential allies in a place of military conflict. On the other hand, a continental power such as the RU is always closer to possible adversaries (e.g. also at their national borders). RU must focus its military capabilities on ground forces and reduce forces and resources for the development of naval and air forces, and must rely in particular on its own capabilities (Eichler, 2017).

RU's constant interest is in consolidating to regain the status of a global power, and its activities are aimed at ensuring strategic stability and the benefits that arise from partnerships in a multipolar world. The RU considers nuclear deterrence and nuclear balance to be the main tools for ensuring strategic 
global stability. This approach is based on the justification that abandoning nuclear deterrence would allow for US dominance based on conventional weapons. RU still considers states in the post-Soviet space as a sphere of its influence (close abroad). RU perceives NATO's eastern enlargement as a direct threat because the defense of RU's territorial integrity is based on buffer zones made up of former postSoviet states (Procházka, Strojar, 2019).

RU has no tendency or reason to withdraw from the application of the neorealist security paradigm, concentrates its forces and resources on increasing the capabilities of its armed forces and strengthens its position as a balancer. It is based on this, as stated by Strojar et al. (2019) that the division of power at the global level between major security actors such as the US, RU and the People's Republic of China (China) is currently evolving and its final paradigm will have a major impact on the future spheres of influence of these actors. This fact confirms the crucial role of the state in international security relations to ensure the sovereignty and prosperity of its citizens and the realization of a balance of power on a global scale.

The annexation of Crimea by the Russian Federation in 2014 became one of the most decisive circumstances of international security relations (especially on the European continent) after the end of the Cold War. RU justified this step as the need to prevent the West (meant under the leadership of the US) from penetrating into the immediate sphere of influence of RU, the so-called near abroad. The subsequent involvement of the Russian Federation in the world has intensified, despite the fact that it is received very negatively in the Western international community and has the character of an unreliable and unpredictable security actor.

When annexing the Crimea, the RU used a hybrid method of conducting a military operation to balance its influence abroad, and did not explicitly use a declaration of war on the enemy to achieve its goal. In the context of conventional definitions, it is a matter of blurring the line between war and peace. This type of operation indicates that the security environment of the European continent has become somewhat unpredictable (Banasik, 2016). It is not empirically proven that the hybrid method of conducting operations is applied only to RU. If only RU operations were conducted by hybrid operations, it would be possible to study this type of operations only through RU operations. Nor is it empirically proven whether RU achieved its set goals within the annexation of Crimea (Käihkö, 2021).

If we compare RU's involvement in international security relations over the last decade, balancing (balancing forces - balance of power) is everywhere. As described by Korolev (2018), when the involvement of the Russian Federation in Georgia (2008), Crimea (2014) and Syria (2015 to date) is in stark contrast to the "theories of the absence of balance" in the professional security and political literature. after the end of the Cold War so popular. The commitment of the Russian Federation confirms its interest in taking on the role of a balancer actor and in reassessing the results of the Cold War.

Just as it is possible to define the annexation of Crimea by RU forces and means using a hybrid method of conducting operations as reviving a realistic paradigm on the European continent in terms of balancing, so the recently signed military-security agreement between the US, UK and Australia can be included in the realistic paradigm. also referred to with the acronym AUKUS. As Mohan (2021) analyzed this paradigm, the security actors of the Indo-Pacific region are not interested in seeking confrontation just to carry out, so to speak, Sizyfa work, which is balancing the influence of the growing superpower in the region in the form of China. However, AUKUS will bring a fundamental change in the region in the form of a new arms race and a reality for the US in the form of the possibility of China's security paradigm of balancing.

The arms race to ensure the security and influence of the actor was not ended by the Cold War. This is evidenced by the signing of the AUKUS agreement and stated in Grohmann's analysis (2021) that the agreement also has a technological-military dimension in that Australia will acquire at least eight nuclear-powered combat submarines from the US instead of twelve diesel-electric combat submarines from French. As a confirmation of the arms race, there is also the fact that Australia does not operate nuclear energy for civilian use and will thus become the first quasi-non-nuclear state with nuclear 
submarines. The AUKUS agreement can also be compared to the UKUSA agreement (initial form 1946, members of Great Britain and the US; adapted form, new members Canada, Australia, New Zealand), which according to Pfluk (2019) has a different focus, but with the same potential balancing of security relationships. UKUSA (also known as the Five Eyes Alliance) was originally aimed at gathering intelligence about the Soviet Union and sharing it with members.

\section{Conclusion}

The realistic paradigm in the security research approach had its greatest justification during the Cold War, at a time of bipolar division of the world into West and East. Actors in international security relations have long confirmed that this paradigm has not disappeared, but rather appears to be acceptable again, and tends to apply in the process of future division of the world order. The building of the future world order was accelerated by e.g. also unilateral decisions of a state actor in the form of annexation of a foreign territory. The greatest influence on the future of the world order will most likely be made by state actors, whose goal has always been and will be to preserve the security of the population, territorial integrity, integrity and sovereignty. This development cannot be realized without conflicts of interest and the need for balancing,

RU's action on the US on the European continent in terms of hybrid operations is a confirmation of the revival of a realistic paradigm. In the politico-military context, the realistic paradigm on the European continent is evident in particular by the extensive annual military strategic exercises, which began in 2020 in the form of DEFENDER-Europe (an exercise led by NATO member states and US-led partners). These exercises can be compared to the continuation of exercises of similar importance during the Cold War called REFORGER (Return of Forces to Germany), which lasted from 1969 to 1993. On the other side of the "barricades" are the Armed Forces, which in four-year cycles carry out strategic exercises alternately in the eastern part of the RU (Vostok), the central part (Centr), in the Caucasus region (Caucasus) and in the western part of the RU (West).

In practice, many decisions taken in the last decade in international security relations by key state actors confirm the propensity for balancing (the paradigm of neorealism). It is obvious that the world has changed in a given decade and the long-proclaimed focus of the US on the Indo-Pacific region (Bush, Obama, Biden) is becoming a reality in the form of e.g. signing security pacts such as AUKUS. What balancing looks like on the European continent is likely to be influenced by the US-led Eurasian paradigm.

\section{Literature}

AZUD, J., (1998). Fundamentals of international law. Banská Bystrica: Faculty of Political Science and International Relations, Matej Bel University. 350 s. ISBN: 80-8055-185-5.

BANASIK, M., (2016). A Changing Security Paradigm. New Roles for New Actors - The Russian Approach. Connections, vol. 15, no. 4, pp. 31-43. ISSN 1812-2973. https://doi.org/10.11610/Connections.15.4.02

BELAN, L., (2015). Security management, Security and risk management. Žilina: University of Žilina in Žilina / EDIS - ŽU Publishing Center. 193 s. ISBN: 978-80-554-1138-5.

CIBULKA, L. et al., (2017). State science. Bratislava: Wolters Kluwer. 358 s. ISBN: 978-80-8168-733 4.

EICHLER, J., (2007). Neorealism and current US-Russian military rivalry in the post-Soviet space. Military views. vol. 26, no. 2, pp. 89-105. ISSN 2336-2995, DOI 10.3849 / 2336-2995.26.2017.02.089105.

GROHMANN, J., (2021). FROMwest shakes: Australia buys US nuclear attack submarines - 2021 [online]. Prague: Internet magazine Armádní noviny, 2021, 17.9.2021 [cit. 2021-09-20]. Available from WWW: 〈https://www.armadninoviny.cz/australie-koupi-jaderne-utocne-ponorky.html>.

HEYWOOD, A., (2008). Political science. Pilsen: Ales Cenek. 537 s. ISBN: 978-80-7380-115-1. 
JURČÁK, V. et al., (2020). Theoretical approaches to security research. Ostrava: Key Publishing. 135 s. ISBN: 978-80-7418-358-4.

JURČÁK, V., TREBULA, M., (2017). On the relationship between security and strategic studies. Culture of Security. Science-Practice-Reflection, no. 28, pp. 94-105. DOI 10.24356 / KB / 28/3.

KAZANSKÝ, R., IVANČÍK, R., (2015). Theoretical basis of conflict investigation. Banská Bystrica: Belianum, Matej Bel University. 224 s. ISBN: 978-80-557-0857-7.

KÄIHKÖ, I. (2021). The Evolution of Hybrid Warfare: Implications for Strategy and the Military Profession. The US Army War College Quarterly: Parameters. vol. 51, no. 3. pp.115-127. ISSN: 00311723

KOROLEV, A. (2018). Theories of Non-Balancing and Russia's Foreign. Policy, Journal of Strategic Studies, vol. 41, no. 6, 887-912 pp., DOI: 10.1080 / 01402390.2017.1283614.

KREJČÍ, O., (2010). International politics. Prague: Ekopres. 751 s. ISBN: 978-80-86929-60-6.

LASICOVÁ, J., (2016). Security The security agenda of today. Banská Bystrica: Matej Bel University. 162 s. ISBN: $80-8083-352-4$

LASICOVÁ, J., UŠIAK J., (2012). Security as a category. Bratislava: Slovak Academy of Sciences. 263 s. ISBN: 978-80-224-1284-1.

MOHAN, CR, (2021). AUKUS, the Quad, and India's Strategic Pivot - 2021 [online]. Washington DC: FP Group, Graham Holdings Company, 2021, 23.9.2021 [cit. 2021-09-26]. Available from WWW: <https://foreignpolicy.com/2021/09/23/india-modi-biden-aukus-quad-summit-geopolitics/\#>.

Pfluke, C., (2019) A history of the Five Eyes Alliance: Possibility for reform and additions, Comparative Strategy, no. 38, vol. 4, pp. 302-315, ISSN 1521-0448. DOI: 10.1080 / 01495933.2019.1633186

PROCHÁDZKA, J., STROJAR, P. (2019). Papproach to the evaluation of the military potential of the state - the example of the Russian Federation. Military views. vol. 28, no.1, pp. 3-15. ISSN 2336-2995.

STROJAR, R., (2020). Security environment. Sectoral analysis and implications for the Armed Forces of the Czech Republic 2019. Brno: University of Defense in Brno. 26 s. ISBN: 978-80-7582-308-3.

UŠIAK, J., NEČAS, P., DOLINEC, V., (2011). Military security sector in the conditions of the Slovak Republic. In VITOVSKÁ J. (eds.). Proceedings of an international scientific conference. Podhájska: Department of Security Studies Faculty of Political Science and International Relations, Matej Bel University, 2011. pp. 218-225. ISBN 978-80-970277-6-6.

UŠIAK, J., NEČAS P., (2010). Napproach to state security at the beginning of the 21 st century. Liptovský Mikuláš: Milan Rastislav Sttefánik Armed Forces Academy. 166 s. ISBN: 978-80-8040-4017.

WAISOVÁ, Š., (2004). ABOUT national security to international security Copenhagen school at the crossroads of structural realism, English school and social constructivism. International Relations, vol. 34, no. 3, pp. 66-86. ISSN 2570-9429. 
Fires in Closed Spaces

DOI: 10.36682/SSS_2021_3

doc. JUDr. Miroslav Felcan, LL.M., PhD., Dr. hc

\author{
Žilinská univerzita $v$ Žilině University of Žilina \\ Ústav znaleckého výskumu a vzdelávania UNIZA Institute of Expert Research and Education UNIZA \\ $\triangle 1$ 1. mája 32, 01026 Žilina, Slovak Republic \\ E-mail:felcan.m@gmail.com
}

Annotation: Every year fires cause big damage to society, property, environment, buildings and infrastructure and pose a threat to life and helath of persons in endangered areas. The subject of the research are areas of fire origin, ie buildings.

Key words: fire, fires in closed spaces, fireraising, deliberately set fire, crime, the burning band

\title{
Introduction
}

Fire is a very complicated and complex phenomenon occurring in various environments under very variable conditions. It includes in particular combustion, heat radiation, turbulence, fluid dynamics and other physical and chemical processes. It causes damage to health and property every year and, last but not least, endangers natural ecosystems. There is an old phrase, but it is true that a deliberate fire is a crime that is easy to commit but harder to solve. Progress in arson investigations will play a key role in reducing this number. Fireplaces are like charred and blackened jigsaw puzzles, where no one starts with a complete picture, but anyone involved in uncovering arson can have its essential parts. Although everyone may have different roles, duties and responsibilities, it is essential for success that so that everyone is aware from the outset of the potential value of the contribution of other members and works together as a team so that they can put the whole picture together exactly. The police have a statutory duty to investigate crimes, and the fire and rescue service currently has statutory authority to routinely determine the origin and cause of fires. The fire and rescue service has a sufficient number of experienced experts and professional teams of fire-fighting providers who are trained to assist in the investigation of the location of the fire and its cause. In other cases, they rely on the professional experience of commanding officers, who have, inter alia, other responsibilities, such as, e.g. fire safety.

The police have a statutory duty to investigate crimes, and the fire and rescue service currently has statutory authority to routinely determine the origin and cause of fires. The fire and rescue service has a sufficient number of experienced experts and professional teams of fire-fighting providers who are trained to assist in the investigation of the location of the fire and its cause. In other cases, they rely on the professional experience of commanding officers, who have, inter alia, other responsibilities, such as, e.g. fire safety. The police have a statutory duty to investigate crimes, and the fire and rescue service currently has statutory authority to routinely determine the origin and cause of fires. The fire and rescue service has a sufficient number of experienced experts and professional teams of fire-fighting providers who are trained to assist in the investigation of the location of the fire and its cause. In other cases, they rely on the professional experience of commanding officers, who have, inter alia, other responsibilities, such as, e.g. fire safety. to assist in the investigation of the location of the fire and its cause. In other cases, they rely on the professional experience of commanding officers, who have, inter alia, other responsibilities, such as, e.g. fire safety. to assist in the investigation of the location of the fire and its cause. In other cases, they rely on the professional experience of commanding officers, who have, inter alia, other responsibilities, such as, e.g. fire safety. 
Based on the study of documentation on past fires, we can assume under what circumstances a fire will occur in a similar environment and under similar conditions. Subsequently, we can determine how the fire will spread in a given environment, how to locate it as quickly as possible, and then extinguish it. The spread of a fire itself is influenced by many different circumstances, including the environment, the surrounding climatic conditions, the type of fuel and its quantity. This can ultimately cause the fire to behave differently. For this reason, it is possible to determine the occurrence and spread of potentially imminent fires only to a limited extent, for objects and conditions of a similar type.

\section{Enclosed fires}

According to $\S 2$ of Act no. 314/2001 as amended is a fire (Act of the National Council of the Slovak Republic no. 314/2001 Coll.): 'Any undesirable burning resulting in damage to property, the environment or the death or injury of a natural person or a dead animal; a fire is also an undesirable burning in which the lives or health of individuals, animals, property or the environment are endangered.

The definition of fire includes the concept of burning, which is also important to clarify at the outset (Act of the National Council of the Slovak Republic no. 314/2001 Coll.): "Burning is a chemical reaction that releases light and heat. The course of combustion requires the presence of a flammable substance, oxygen and a source of ignition, the so-called components of the combustion triangle ', see Figure 1 .

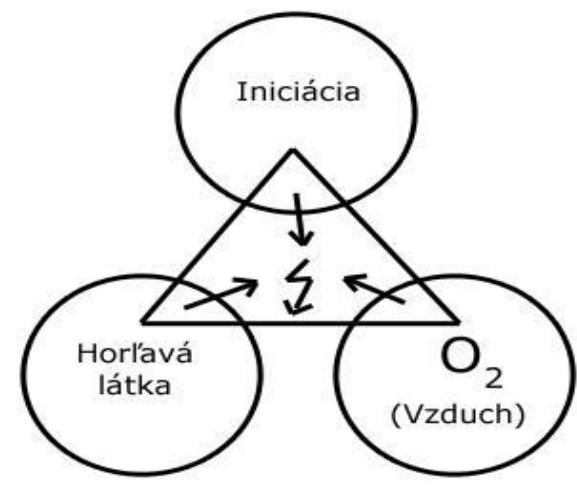

Figure 1: Burning triangle

\section{Burning can be:}

- homogeneous, thus flaming above the surface of a combustible substance, when gases released at high temperature burn,

- heterogeneous, which is combustion on the surface of a flammable substance that is not capable of forming flammable gases.

\section{We also divide combustion into:}

- perfect, whose products can no longer burn, the prerequisite is a sufficient supply of air, it produces carbon dioxide during combustion.

- imperfect, the products of which may still burn, takes place with insufficient access of oxygen to the combustion, and carbon monoxide is formed.

\section{Fire zones:}

The space in which the fire and its accompanying phenomena take place can be divided into three interrelated zones. See Figure 2 (Act of the National Council of the Slovak Republic no. 314/2001 Coll.):

- burning zone,

- preparation zone,

- smoke band.

Burning zone includes the part of the space in which the processes of thermal decomposition of solid flammable substances or conversion of flammable liquids into vapor, combustion of gases and vapors 
in the volume of the diffuse flame take place. The combustion zone represents the volume of vapors and gases bounded by the surface layer of the flame and the surface of the combustion substances. In some cases, the burning zone is delimited by structural elements of buildings, walls.

Training zone consists of a frequent environment in close proximity to the combustion zone, in which heat is exchanged between the surface of the flame and the surrounding structures and flammable substances. Combustible substances are being prepared for combustion and there is a real possibility of further spread of the fire.

Smoke band we call a part of the area near the combustion zone, which is filled with smoke, ie gaseous products of combustion in concentrations dangerous to the health and life of persons or complicating the operation of fire brigades. In the case of open fires, this zone depends on:

- the growth rate of the burning area,

- burn rate,

- meteorological conditions.

The growth of the burning area and the rate of burning have a greater effect on the volume of the smoke zone and meteorological conditions on the density of the smoke and the position of the smoke zone (Arioz, 2007).

The area and movement of the smoke zone in case of fires inside the building is affected by the gas exchange, which depends on the number, distribution and area of the openings. The burning zone, the preparation zone and the smoke zone differ for each fire in size, shape and also in the characteristics of the course (Babauskas, 2016). In fire tactics, the most important are those parameters that determine the amount of forces and resources needed to extinguish and other combat activities of units.

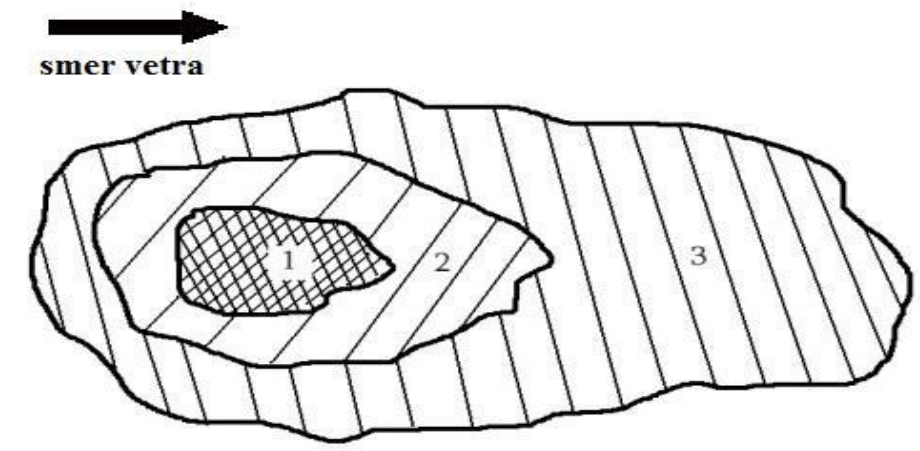

Figure 2: Fire zones: 1 Burning zone; 2. Training zone; 3. Smoke band

\subsection{Fire phases}

The intensity of fires changes during burning. The course of a fire is usually characterized by four phases, the length of which may vary depending on the amount of combustible materials, their firetechnical properties and other conditions that affect the course of the fire. In terms of time and temperature characteristics of the fire, we can divide its probable course into phases (Arioz, 2007):

- initiation,

- fire development,

- fully developed fire,

- interruption of the combustion process.

Initiation is the period from the start of a fire to the beginning of intense burning. According to statistics, it usually lasts 3-10 minutes and depends on the type of flammable substances and the conditions of fire development, Figure 3. Due to the fact that the intensity of combustion is relatively small (only part of 
combustible materials burn), this phase is most advantageous to start liquidation. fire. Disposal is easy and the damage is small.

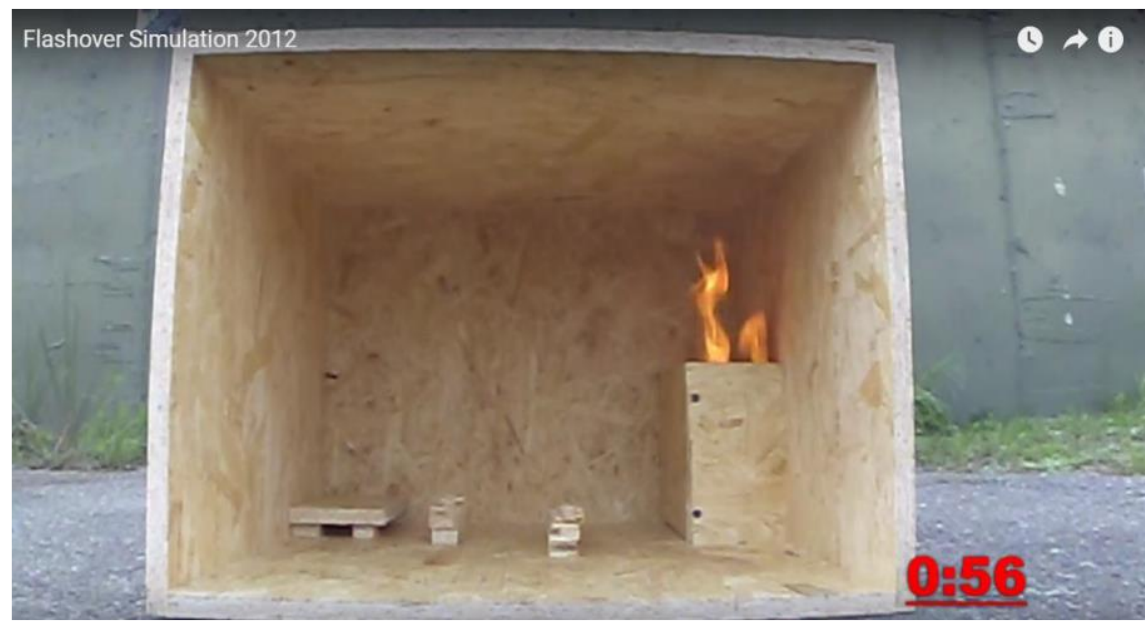

Figure 3: I. Phase of the fire (Bradáčová, et.al., 1999).

Fire development is the time period from the beginning of intense combustion until the time when all combustible materials and structures of the burning object are affected, Figure 4. This phase is characterized by a sharp increase in temperature and fire area, increase in gas exchange intensity and proportional increase in damage. The situation at the scene of a fire is difficult and requires high demands on the organization of firefighting work.

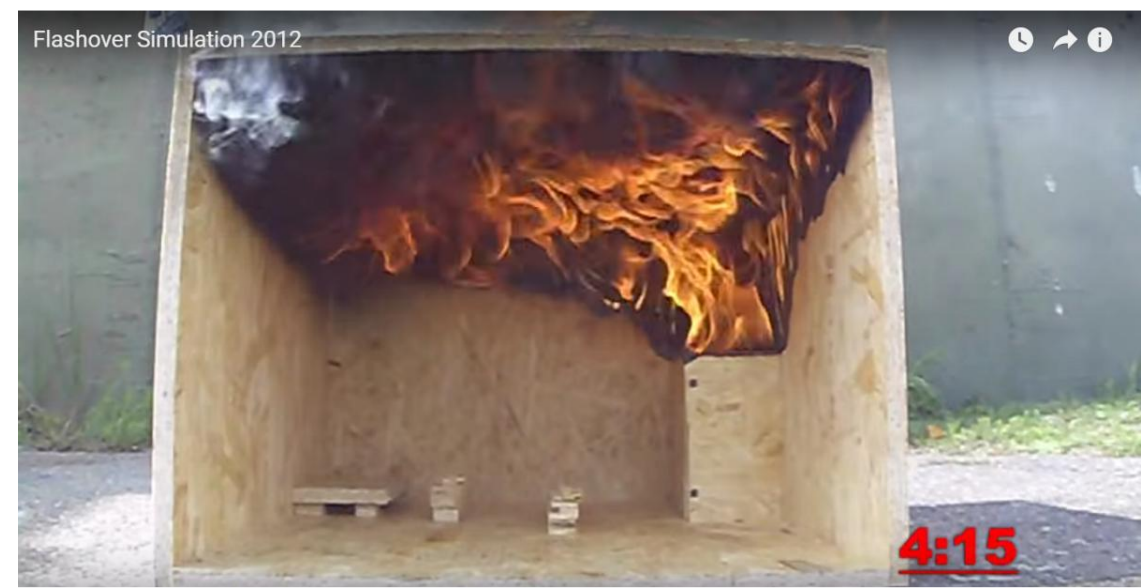

Figure 4: II. Fire phase (Bradáčová et.al., 1999).

Fully developed fire is the time period from the end of II. phase, ie in the given building all flammable substances burn and the intensity of combustion reaches a maximum until the beginning of the decrease of burning intensity, Figure 5. In this phase, other load-bearing elements are disturbed and the ceiling, truss, etc. collapse. The intervention of the units focuses on cooling and protection of the surrounding objects and it is up to the commander of the intervention whether he will perform the intervention on the burning object, or whether it will not be more appropriate to let the affected object burn. 


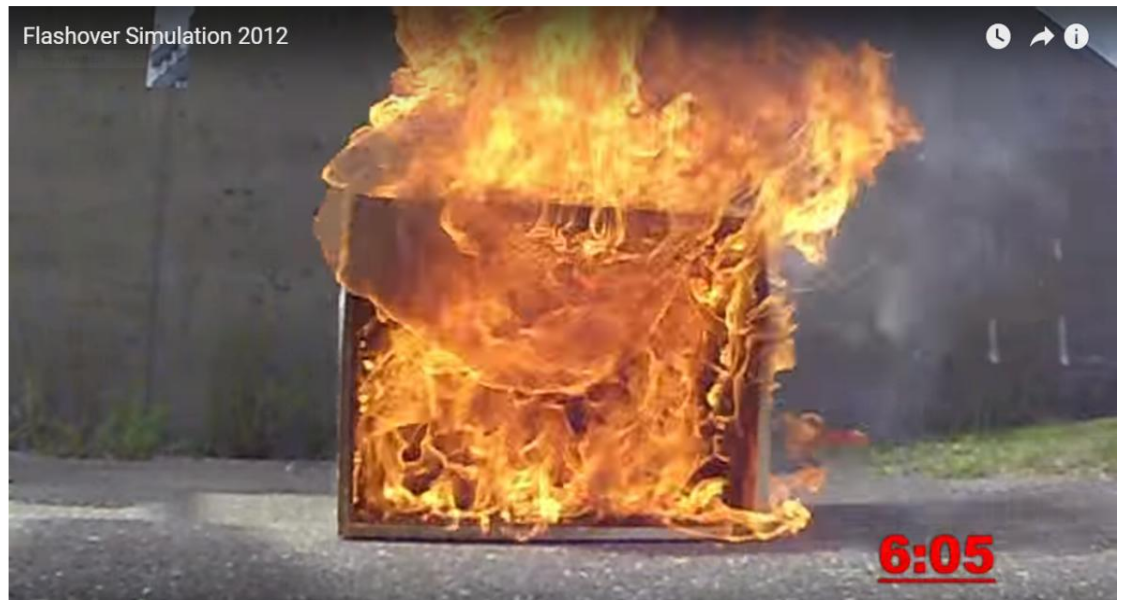

Figure 5 III .: Fire phase (Bradáčová, et.al. 1999).

Interruption of combustion is the period from the beginning of the reduction of the burning intensity until the complete burning of the flammable substances. In this phase, there is a risk of collapse of internal and peripheral masonry, chimneys, stairs, etc., Figure 6. The activity of the units is focused on exposing and extinguishing fire fires, unless the commander of the intervention has decided that only supervision will be carried out on the building until complete burnout.

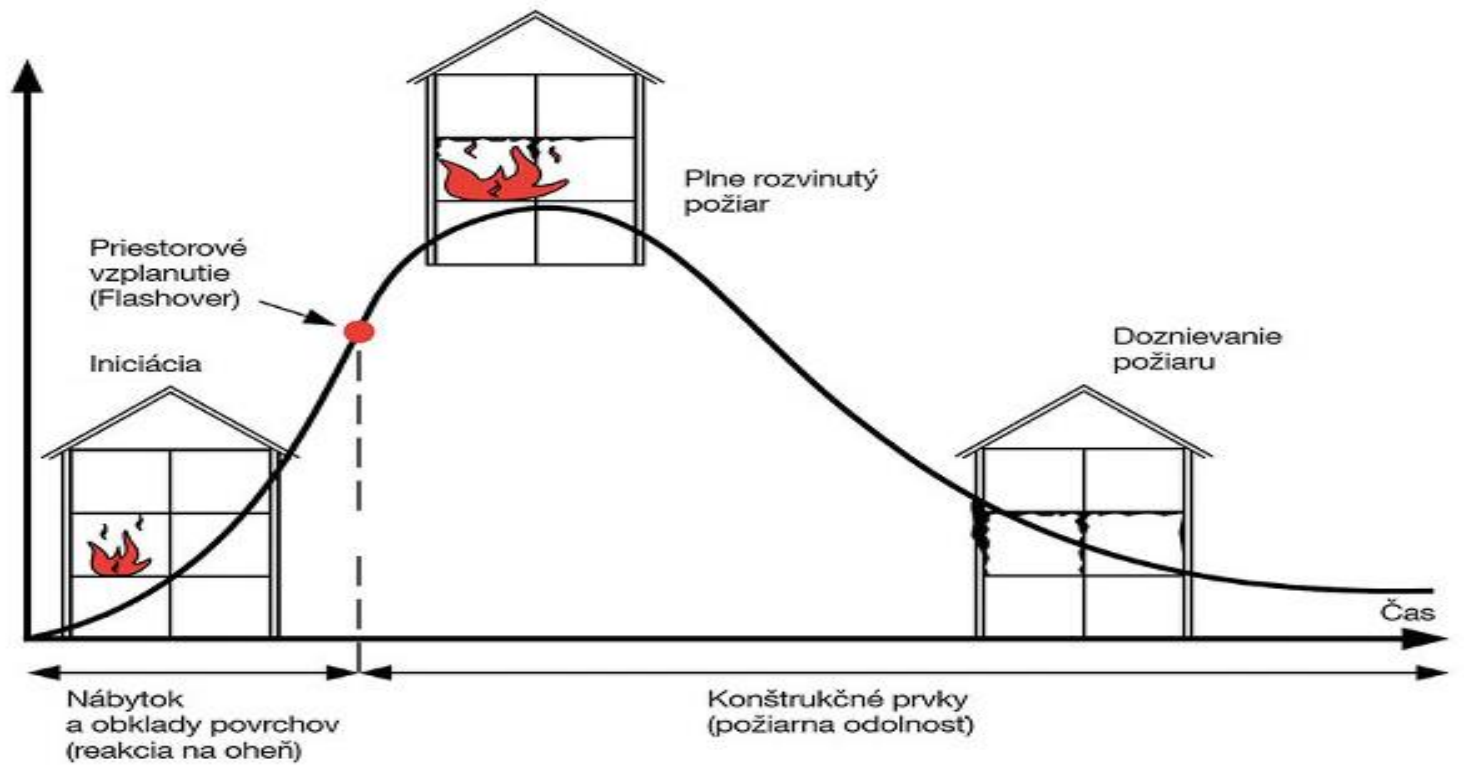

Figure 6: Phases of the fire

\subsection{Internal fires}

Internal fire jmay be defined as a fire which has occurred in an enclosed space of a building, killing persons, animals or directly endangering their health (BS EN ISO 13943 2010). An internal fire can also be considered a fire in which material damage occurred.

According to the detectability, we divide internal fires into (Vladimirovich, 2008):

- open (visible flame, smoke),

- $\quad$ hidden (fire that is not visible, shafts, pipes).

According to the cause of the fire, we divide them into:

- man-made (intentionally or through negligence),

- not caused by man (electrical short circuit).

Internal fire is a complex phenomenon involving many physical and chemical processes, such as: 
- combustion,

- radiation propagation,

- heat radiation,

- fluid dynamics,

- turbulent gas flow.

Fires in the interiors of residential buildings or family houses are characterized by the fact that they are very dangerous. They are characterized by high temperatures, dense smoke and the production of toxic combustion products. Fires of this type can spread very quickly, which is caused by a large amount of flammable substances in living spaces such as sofas, paintings, carpets or furniture, which can complicate emergency work and fire extinguishing (Vrábl'ová, 2015). The specificity of such fires is that they are bounded by building structures. Such fires then depend not only on the equipment of the premises (their fire load), but also on the dimensions, geometry, method of ventilation and oxygen supply (STN 73 0540-1: 2002).

An enclosed fire can therefore have several scenarios (Balog et al., 1999):

1. The fire will not spread to other flammable materials, the only thing that will burn will be the fuel.

2. Similar scenario as in the first point, but not enough oxidant is available.

3. The fire has sufficient ventilation and the amount of fuel. As a result, it develops freely in an enclosed space and the fire spreads to all combustible materials.

4. Flame burning is very slow, or only decay takes place. Combustible gases are formed containing a significant proportion of unburned flammable gases. Subsequent penetration of the oxidizing agent leads to reheating or even explosive combustion.

5. Flame combustion is very slow, or decay, where after the introduction of the oxidizing agent there is a new combustion of the fuel with subsequent spatial ignition. In this case, the fire has sufficient ventilation and fuel. This is followed by an extension to other combustible material in the area.

6. Breathing fire is a phenomenon where the fire is controlled by ventilation. It is caused by a decrease in the rate of heat release due to a limited amount of oxygen.

The speed of the spread of the fire (horizontal spread of the flame) depends mainly on:

- ignition temperature,

- thermal properties of materials,

- the intensity of the heat flux of the flame.

The speed of fire spread in the living room is approximately $0.7 \mathrm{~m} / \mathrm{min}$. In the case of a forest fire, it is $1.3 \mathrm{~m} / \mathrm{min}$. These are indicative data, as the actual speed depends on a number of factors. In the event of internal fires, there is also a risk of spreading through the openings to higher floors. The rate of combustion of the material depends on the chemical and physical properties of the substances, their distribution, gas exchange, etc.

A great danger, as already mentioned, is smoke and the associated formation of toxic combustion products and CO. In statistics, suffocation or poisoning is the most common cause of death in internal fires, followed by burns. That is why ventilation is an important activity, which the intervening units must provide in the interior, either by opening windows or doors, using a portable fan. As a result, they can reduce smoke and the concentration of hazardous emissions, increasing visibility to several meters.

In a smoky space under fire conditions, visibility can be literally zero and the intervening units only have to rely on the correct orientation in the space, while it is important that they maintain contact from the wall and communication with others.

\subsection{Development of internal fires}

The beginning of the fire in buildings corresponds to the course of a fire in an open space with limited climatic conditions. However, the combustion conditions in the room change rapidly. The conditions in 
which the combustion is initiated depend on the concentration of oxygen and fuel, the time when the ignition source (flame, spark, radiant heat) acts.

Due to the development of smoke, also with regard to the consumption of oxygen during combustion, its concentration and thus the course of combustion in an enclosed space is constantly decreasing. The interface between the smoke and air layer decreases towards the floor. It depends on the type and construction of the space and the course of the fire how the development of the fire will continue. The course of a fire in a room is also affected by the temperature with which the properties of building structures and the combustible materials used change. There is also an acceleration of the combustion process and also the conditions for the intervention of units deteriorate. Non-combustible materials and structures change shape due to high temperatures, or melt or change their state.

The exchange of gases, namely the number, size and location of openings, has a fundamental influence on the further course of the fire. Air exchange occurs due to the difference in temperature and pressure between the room and the environment and due to the action of the wind. In buildings with a minimum number of openings or where the air exchange is ensured by ventilation, flame combustion takes place at these openings. If all structures and hole closures have a sufficiently high fire resistance and are not deformed during a fire, the case may be interrupted by burning.

In other cases, there is a fire in buildings for fully but also partially open openings. With a large area of openings, a fire is characterized by a high rate of fire spread due to a sufficient supply of atmospheric oxygen. The predominant direction of movement of the combustion zone is the direction to the side of the open holes. In such intense combustion, the rate of development of decomposition products exceeds the rate of oxygen supply and mixing; decomposition products escape together with carbon monoxide, which is formed during imperfect combustion together with flue gases from the building and burns there in the open. Burning is manifested by the fact that flames whip out of the openings, which can cause the fire to spread to the surrounding environment. The course of a fire in buildings depends on the amount and properties of burning substances and the exchange of gases, which depend mainly on the size and position of the open holes. The course of flue gas and air exchange can also be affected by the installed ventilation equipment.

\section{Factors influencing the development of internal fires}

The development of a fire depends on several factors. In general, these are factors such as the characteristics of flammable substances (physical, chemical properties), gas exchange conditions, heat transfer conditions, explosions and explosions, fire propagation routes, structural resistance and meteorological situation (Reichel, 1981).

However, in the conditions of internal fires, the factors also differ slightly. Factors influencing the development of internal fires are (STN EN 73 0031: 1990):

- the size and location of the initiation source,

- type, location, size, quantity, orientation and surface area of the fuel,

- geometry of an enclosed space,

- the size and location of ventilation openings in the room,

- material properties of the boundary space.

A spark with a very low energy content, a hot heated surface or a flame can act as the initiating source. The source can be chemical, electrical or mechanical energy. The larger the initiation source, the faster the subsequent increase in the fire of combustible material. The method of combustion depends on the method of initiation. When initiated by a spark, there is usually a flameless burning, the flames will appear later. The moment when the flames appear can take a long time, because they usually form low temperatures and this combustion is accompanied by a large amount of 20 toxic gases. When initiated by a controlled flame, a flame burn usually occurs. The location of the combustion source is also important during initiation. This source can be placed close to burning substances, which would subsequently promote combustion in the room. Also, the lower the initiator, the faster the burning. 
Another and very important factor is the method of distribution of combustible material, their size, amount and surface area. The position of the flammable substance in the room is important, the position in relation to other flammable materials (their mutual distance). When spreading a fire in interiors, it is also necessary to take into account whether the walls are lined with flammable material, because vertically the fire spreads faster than horizontally. With the same weight of flammable substance, the area is important. The more fragmented the surface, ie the larger the area, the sooner the substance ignites. Rather, $1 \mathrm{~kg}$ of sawdust ignites as a whole piece of an equally heavy cube made of the same wood.In enclosed spaces, these are most often solid materials of interior equipment. Heavy wooden furniture causes a slow development of fire, but the fire reaches large dimensions compared to new modern plastic furniture. A rapid rise is much more dangerous than a large fire. It also depends on where the fuel is stored, whether it is stored near walls or in a room. This is because better access to cold air is possible in the space than with walls. The distances between combustible materials are also important, as this affects the rate at which the fire will spread. Flames propagate faster than flames propagating horizontally. Therefore, it depends on whether the walls and ceilings are lined with flammable materials. This can also cause a rapid fire to develop.

The material of the boundary surfaces of the enclosure can affect the temperature of the hot gases and thus the temperature of the flow to the burning fuel and other flammable substances. It is important what properties these materials have. The decisive properties are conductivity, density and heat capacity. The geometry of the enclosure also significantly affects the development of the fire. The geometry of the room is related to gas temperatures and the amount of air in the room Assuming that the two rooms have the same amount of flammable substance, it can be compared. With the geometry of the rooms, a lot depends on the floor area and the height of the ceiling. If the fire takes place in a small room, the temperature is high and rises rapidly. But when a fire takes place in a large hall, the same amount of fuel does not reach such a temperature if the space becomes smoky later. If one room had smaller dimensions and a lower ceiling, the fire would spread faster (more flammable substances are in the preparation zone). With a lower ceiling, the space smokes faster. Also, a low ceiling can cause the flames to feedback to the fuel and thus affect the burning rate. In rooms with a large floor plan and high ceiling, the fire spreads more by radiation from the fire to other flammable materials present; There is also an important placement of these items. If it burns in a medium-sized room that is closed or has very small openings, the fire begins to have very little oxygen and may go out or continue to burn very slowly (Reichel, 1981; Reichel, 1977). With a lower ceiling, the space smokes faster. Also, a low ceiling can cause the flames to feedback to the fuel and thus affect the burning rate. In rooms with a large floor plan and high ceiling, the fire spreads more by radiation from the fire to other flammable materials present;

There is also an important placement of these items. If it burns in a medium-sized room that is closed or has very small openings, the fire begins to have very little oxygen and may go out or continue to burn very slowly (Reichel, 1981; Reichel, 1977). With a lower ceiling, the space smokes faster. Also, a low ceiling can cause the flames to feedback to the fuel and thus affect the burning rate. In rooms with a large floor plan and high ceiling, the fire spreads more by radiation from the fire to other flammable materials present; There is also an important placement of these items. If it burns in a medium-sized room that is closed or has very small openings, the fire begins to have very little oxygen and may go out or continue to burn very slowly (Reichel, 1981; Reichel, 1977). There is also an important placement of these items. If it burns in a medium-sized room that is closed or has very small openings, the fire begins to have very little oxygen and may go out or continue to burn very slowly (Reichel, 1981; Reichel, 1977). There is also an important placement of these items. If it burns in a medium-sized room that is closed or has very small openings, the fire begins to have very little oxygen and may go out or continue to burn very slowly (Reichel, 1981; Reichel, 1977).

Gas flow in an internal fire, which is also typical of the release of heat and the formation of combustion products. Combustion products have a larger volume than the flammable substance. Thus, during an internal fire, the gas pressure increases. In the case of an internal fire, the combustion products rise upwards to the ceiling due to the rising temperature and also accumulate there. The volume of flue gases increases with the development of combustion and the space is filled with smoke after mixing with air. The neutral plane shows the interface between the smoky space and the clean environment. From the 
point of view of ventilation resp. ventilation, it is necessary to provide activities to systematically direct smoke and heat from the place where the fire is in the building (Valíček et al., 2012).

\subsection{Parameters of internal fires}

Individual models, when applied correctly and when entering all the required input data, are able to provide a comprehensive picture of certain fire parameters according to the purpose of the model. Some parameters of a fire in its certain phases can also be determined by calculation. These calculations are often simplified in practice due to the complexity of the fire process and also the possibility to apply them is limited by the changing values of the fire parameters in its individual phases.

\section{Heat release rate}

The heat release rate (HRR) is the energy released by a burning material per unit time. This quantity is the basic parameter for determining the burning intensity. It can be determined by oxygen calorimetry. The essence of this method is that most substances release a constant amount of energy per unit amount of oxygen consumed. This constant is $13.1 \mathrm{MJ}( \pm 5 \%)$ per kilogram of oxygen consumed (Blomqvist et al., 2004).

Another method of determining the rate of heat release is to calculate the mass burn rate and the effective calorific value according to the relationship:

$$
\dot{Q}=m \Delta H_{e f f}
$$

Where:

Q- heat release rate, HRR $(\mathrm{kW})$

m- mass burn rate (kg.s $\left.{ }^{-1}\right)$

$\mathrm{H}_{\text {eff }}$ - effective calorific value ( $\left.\mathrm{kJ} \mathrm{kg}^{-1}\right)$

Factors influencing the movement of gases in enclosed spaces

During the development of a fire, the pressure conditions in an enclosed space change. During a fire, heat is released and combustion products are formed, which is interesting in that they have a larger volume than the original combustible substance and in the space, the pressure of the gases increases. The temperature in the area where the fire takes place increases and with the temperature the volume of air and also the combustion products increase. Due to the increasing temperature and pressure of the gases, heat and gases are exchanged between the combustion chamber and the surroundings. In the case of a fire in an open area, due to the rising temperature of the combustion products and due to the pressure difference between the combustion area and the surroundings, the combustion products flow upwards (Smartfire Fire Field Modeling Environment, 2008).

In buildings, when burning, due to the rising temperature in the space, the combustion products rise upwards towards the ceiling, where they accumulate. With the development of combustion, the volume of flue gases increases and after mixing with air, the space is filled with smoke. INthus, an overpressure is created in the upper parts of the space, and an underpressure in the lower parts of the space. The boundary between the overpressure and underpressure part is formed by a neutral plane. At the point of the neutral plane, the pressure is atmospheric (Grosshandler, 1993). The position of the neutral plane at a known overpressure value can be determined according to the following relation (STN 92 0201-1: 2000):

$$
z_{n}=\frac{\Delta p_{i j}}{\left(\rho_{i}-\rho_{j}\right) g}
$$

Where:

zn - height of the neutral plane (m) 
drink - overpressure value $(\mathrm{Pa})$

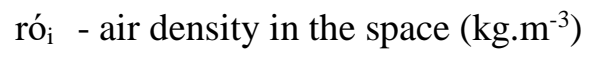

rój - air density in the space $\left(\mathrm{kg} \cdot \mathrm{m}^{-3}\right)$

g - gravitational acceleration $\left(\mathrm{m} \cdot \mathrm{s}^{-2}\right)$.

Pressure conditions and other factors in enclosed spaces are of less or greater importance in terms of gas movement. The basic factors affecting the movement of smoke in buildings can include:

- chimney effect,

- buoyancy,

- increasing gas volumes,

- wind,

- air conditioning equipment.

The exchange of gases through a vertical opening with two-way flow can be determined by the following relations:

$$
\begin{aligned}
& m_{i j}=\frac{2}{3} C_{D} \sqrt{2 \rho_{i}\left(\rho_{j}-\rho_{i}\right) g}\left(\frac{\left(\rho_{j} / \rho_{i}\right)^{1 / 3}}{1+\left(\rho_{j} / \rho_{i}\right)^{1 / 3}}\right)^{3 / 2} \mathbf{B}_{o}\left(H_{u}-H_{l}\right)^{3 / 2} \\
& m_{j i}=\frac{2}{3} C_{D} \sqrt{2 \rho_{j}\left(\rho_{j}-\rho_{i}\right) g}\left(\frac{1}{1+\left(\rho_{j} / \rho_{i}\right)^{1 / 3}}\right)^{3 / 2} \mathbf{B}_{o}\left(H_{u}-H_{l}\right)^{3 / 2}
\end{aligned}
$$

Where:

me- mass Amount of gases flowing through the opening from the i-th to the j-th space (kg.s

$\rho_{\mathrm{i}}$ - air density in the space (kg. $\left.\mathrm{m}^{-3}\right)$

$\rho j$ - air density in the space $\left(\mathrm{kg} \cdot \mathrm{m}^{-3}\right)$

$\mathrm{g}$ - gravitational acceleration $\left(\mathrm{m} \cdot \mathrm{s}^{-2}\right)$

CD - outflow coefficient (-)

$\mathrm{B}_{\text {about }}$ - width of the hole in meters (m)

$\mathrm{Hu}$ - height of the upper edge of the hole (m)

$\mathrm{H}_{1}$ - height of the lower edge of the hole (m)

\subsection{Gas temperature in the combustion chamber}

Technical practice often needs to know the approximate temperatures inside the combustion chamber during the various phases of a fire. Prior to volumetric ignition, the temperature is important, especially because of the persons present inside the combustion chamber. After volumetric ignition, when the fire spreads to most of the space, it is important to monitor the development of temperatures in the space in order to correctly determine the fire resistance of building structures (Müllerová, Vácval, 2016).

The fire resistance of the structure is evaluated by specified criteria and time in minutes (Decree of the Ministry of Interior No. 94/2004). The following criteria and symbols are used to evaluate the fire resistance of structures (Decree of the Ministry of Interior of the Slovak Republic No. 94/2004 Coll.):

- R - load capacity, stability.

- E - integrity. 
- I - thermal insulation.

- $\quad \mathrm{W}$ - radiation controlled insulation.

- M - mechanical resistance.

- C - self-closing.

- $\quad$ - smoke tightness.

- $\mathrm{G}$ - resistance to fire (burning) of carbon black.

- $\quad \mathrm{K}$ - fire protection capability.

\section{Gas temperature before volumetric ignition}

McCaffrey and his colleagues performed more than 100 experimental fires with cellulosic and synthetic materials or gaseous hydrocarbon fuels in rooms ranging in height from $0.3 \mathrm{~m}$ to $2.7 \mathrm{~m}$ and in floor areas ranging from $0.14 \mathrm{~m} 2$ to $12 \mathrm{~m} 2$ (McCaffrey et al., 1981). The test rooms also had different dimensions of windows, doors and the structures delimiting these rooms were made of different materials. From the results of experimental measurements, the following relationship of temperature increase in the burning space was determined (McCaffrey et al., 1981):

$$
\Delta T_{g}=6.85\left(\frac{\dot{Q}^{2}}{A_{o} \sqrt{H_{o}} h_{k} A_{T}}\right)^{1 / 3}
$$

\section{Where:}

$\mathrm{Tg}$ - temperature rise in the combustion chamber $\left({ }^{\circ} \mathrm{C}\right)$

$\mathrm{Q}$ - heat release rate $(\mathrm{kW})$

Ao - hole area $\left(\mathrm{m}^{2}\right)$

$\mathrm{H}$ - hole height (m)

hk - heat transfer coefficient $\left(\mathrm{kW} \cdot \mathrm{m}^{-2} \cdot \mathrm{K}^{-1}\right)$

AT - total area of structures in the PO excluding openings $\left(\mathrm{m}^{2}\right)$

\section{Gas temperature after volume ignition}

The temperature of the gases in the closed burning space after the volume ignition characterizing the development of the temperature in the fire section is most often described by temperature curves. The standard temperature curve is defined by various national standards organizations and is used to determine the fire resistance of building elements, Figure 7. (Müllerová, 2016). Its application is limited to the approximation of the fire temperature after a volume ignition.

$$
T_{g}=20+345 \log _{10}(8 t+1)
$$

Where:

$\mathrm{Tg}$ - gas temperature in the fire compartment $\left({ }^{\circ} \mathrm{C}\right)$

$\mathrm{t}$ - time (min.) 


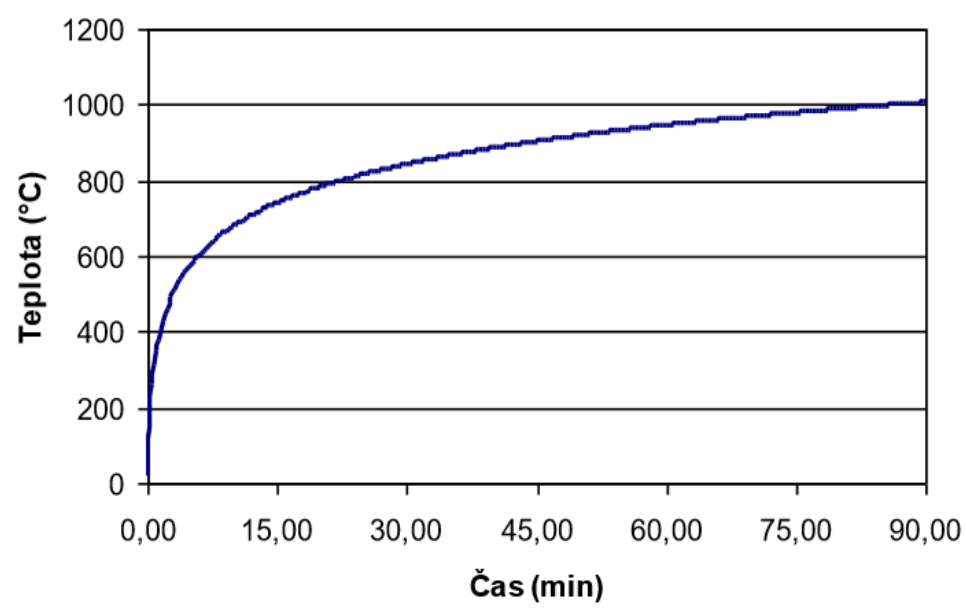

Figure 7 Standard temperature curve

In addition to the standard temperature curve, there is also a hydrocarbon curve allowing the simulation of a fire with a rapid increase in intensity. Fully developed fires of flammable liquids can be represented by this curve. The external fire curve is used to assess the thermal load of structural elements occurring outside the building. The application of a slow heating curve is suitable provided that the fire resistance of the element may be reduced by its exposed temperatures associated with the unfolding fire.

\section{CONCLUSION}

Fires have been a problem of every community since time immemorial. The fire selects victims for human lives, their health, property, endangering entire cities, but also ecosystems. For sufficient prevention, as perfect prevention is almost impossible, it is necessary to have as much knowledge as possible about fires and to know their behavior in the room and in the open. By understanding the spread of fire, we will be able to limit its consequences.

Slovak legal standards are focused on the development of fire safety of buildings on the basis of technical standards and decrees. This method is sophisticated and functional, and in general it can be stated that it is sufficient for almost all situations. Someone said that a fire could be one of the fastest and most devastating ways to stop a business. Nowadays, there are more fires in all kinds of businesses, whether industrial buildings or buildings intended for the public, from arson, which are intentionally started for any reason. These deliberate fires are often associated with the intrusion and masking of robbery. In order to avoid the closure of the company for these or other reasons, management must consider as an integral part of business planning, with each type of risk and must take such measures as to prevent their occurrence or reduce their effect. Planning measures against intentional fires must be part of management's safety policy to protect people and property from fires. Management responsibility is focused on the analysis of the risk of arson (ie the vulnerability of the company to arson from outside and inside), consideration of the effectiveness of various auxiliary measurements and their price, the relationship of risk analysis and auxiliary measurements to overall fire safety and safety program in the company.

The history of fire protection is as old as the very discovery of fire by humans. People quickly realized that if a fire got out of control or handled carelessly, it could endanger their own lives or property. Gradually, as the company developed, fire protection also developed. Legislation and Slovak technical standards shall indicate any undesirable burning in which the lives or health of natural persons or animals, property or the environment in which damage to property, the environment occurs or which results in injury or death of a natural person or animal are immediately endangered. the term "fire". In general, we say that a fire is a burning that takes place outside a designated area, ie a burning that causes material damage to society and loss of life of people and animals. 
The paper was processed as one of the outputs of "VVÚ No. 245/2019 - Modern technologies in the detection, documentation, evidence and prevention of crime in ensuring public order, safety and fluidity of land transport".

\section{LITERATURE}

Act of the National Council of the Slovak Republic no. 314/2001 Coll. on fire protection as amended.

ARIOZ, O. (2007). Effects of elevated temperatures on properties of concrete. In Fire safety journal, 42, 8 , p. $516-522$.

BABAUSKAS, V. (2016). Electrical Fires, SFPE Handbook of Fire Protection Engineering, Springer, New York, p. 662-704.

BALOG, K., KVARČÁK, M. (1999). Fire dynamics. Ostrava: SPBI, 96p. ISBN-80-86111-44-X.

BLOMQVIST, P., ROSELL, L., SIMONSON, M. (2004). Emission from Fires Part II: Simulated Room Fires. In Fire technology journal, ISSN 0015-2684, 2004, 40, 1, p. 59-73.

BRADÁČOVÁ, I. et.al. (1999). Buildings and their fire safety. Publisher information: Praha: ŠEL, 264 s. ISBN 80-902697-2-9.

BS EN ISO 13943 (2010). Fire Safety - Vocabulary.

Decree of the Ministry of Interior no. 94/2004 Coll., Which lays down technical requirements for fire safety during construction and use of buildings STN ISO 018200: 1991: Fire characteristics of substances. Terms and definitions.

GROSSHANDLER, W. (1993). RadCal a Narrow Band Model for Radiation Calculations in a Combustion Environment. NIST Technical Note 1402, National Institute of Standards and Technology, Gaithersburg, Maryland.

MCCAFFREY, BJ, QUINTIERRE, JG, HARKLEROAD, MF (1981). Estimating room temperatures and the likelihood of flashover using fire test data correlations. In Fire technology, No 17. No. 2. p. 98 119.

MÜLLER, J. (2016). Flashover fire modeling by real small-scale models. In: SGEM 2016: ecology, economics, education and legislation, Albena, Bulgaria. Volume II. - Sofia: STEF92 Technology, 2016. ISBN 978-619710556-8.

MÜLLEROVÁ, J., FELCAN, M. (2017). Modeling of internal fires 1st ed. - Hodonín: European Institute of Law and Forensic Engineering, 341 p. ISBN 978-80-906601-1-3.

MÜLLEROVÁ, J., VÁCVAL, J. (2016). Fire safety characteristic of oak wood and medium-density fiberboard In: Production management and engineering sciences. Leiden; London: CRC Press / Balkema; Taylor \& Francis Group. ISBN 978-1-138-02856-2. with. 207-211.

REICHEL, V. (1978). Designing fire safety of buildings, Part I, SNTL, ČSP, 1977, II. Part, VÚPS, Prague 1978.

REICHEL, V. (1981). Determination of requirements for building structures in terms of fire safety, 1st edition, Fire Protection Association of the Czechoslovak Socialist Republic, Prague.

SMARTFIRE (2008). Fire Field Modeling Environment. CFD Models Survey. [online]. Updated 2008 [cit. 2016-02-18]. Available at: http: //www.firemodelsurvey.com-/pdf/SMARTFIRE_2007.pdf.

STN 73 0540-1 (2002). Thermal technical properties of building structures and buildings. Thermal protection of buildings. Part 1: Terminology.

STN 92 0201-1 (2000). Fire safety of buildings. Common provisions. Part 1: Fire risk, size of fire compartment.

VALÍČEK J., MÜLLEROVÁ J., KUBĚNA K., KOŠTIAL P., HARNIČÁROVÁ M., MIKULÍK M. (2012). Emission distribution and regulation of local heat source, Diffusion in solids and liquids, 
Portugal, Trans Tech Publications Switzerland, 2012, pp.330-334, Emission distribution and regulation of local heat source, Diffusion in solids and liquids, Portugal, Trans Tech Publications Switzerland, pp.330-334.

VLADIMIROVIČ, S. (2008). Improving the training of members of fire brigades based on the technology of simulation modeling of fires in buildings. Dissertation, Moscow: AGPS. $113 \mathrm{~s}$.

VRÁBLOVÁ, L'. (2015). Modeling of risk situations in the simulator for nonlinear forms of fires. Dissertation, FBI, University of Žilina. 


\title{
Identification and Evaluation of the Important Objects within a Territory in the Context of a Blackout
}

DOI: 10.36682/SSS_2021_4

\section{PhDr. Tomáš Fröhlich, DiS.}

\author{
SECURU s.r.o. SECURU s.r.o. \\ Bezpečnostni poradenství Security Consulting \\ Katedra zdravotnických oborù a ochrany Department of Health Care and Population Protection \\ obyvatelstva Faculty of Biomedical Engineering \\ Fakulta biomedicinského inženýrství Czech Technical University in Prague \\ České vysoké učeni technické v Praze \\ $\triangle$ Vrbova 19, 147 00, Praha 4 - Branik, Česká republika \\ $\triangle$ nám. Sitná 3105, Kladno, Česká republika \\ E-mail: tomas.frohlich@securu.cz
}

Ing. Jiří Slabý, Ph.D.

SECURU s.r.o. SECURU s.r.o.

Bezpečnostni poradenstvi Security Consulting

$\triangle$ Vrbova 19, 147 00, Praha 4 - Branik, Česká republika

E-mail: jiri.slaby@securu.cz

doc. Mgr. Zdeněk Hon, Ph.D.

Katedra zdravotnických oborů a ochrany Department of Health Care and Population Protection obyvatelstva Faculty of Biomedical Engineering

Fakulta biomedicinského inženýrství Czech Technical University in Prague České vysoké učení technické v Praze

$\triangle$ nám. Sitná 3105, Kladno, Česká republika

E-mail: zdenek.hon@fbmi.cvut.cz.

\begin{abstract}
Annotation
The reliable and secure power supply is the key element, which substantially affects contemporary society. Excessive long-term power outage (also referred to as a power blackout) has in many cases irreversible socio-economic impacts. The infrastructure stops its operation; thus territory services are greatly limited. As the duration of the outage prolongs people tend to behave more instinctively rather than logically. The important goal is to avoid or significantly limit the impacts of such instinctive behavior by implementing adequate measures in advance. This article discusses the approach how to strengthen the resilience of the territory against power supply failure.
\end{abstract}

\section{Key words}

Power outage, Blackout, Resilience, Territory, Population, Important objects

\section{Introduction}

The energy sector and the services it provides are among the fundamental pillars of every community and every country. A particularly important and irreplaceable position within this sector is occupied by the electricity sector, which is an integral part of human existence. Especially today's post-industrial civilization and its constant technical and technological development of global dimensions is characterized by complete dependence on quality and reliable electricity supplies, literally in a 
continuous mode (Bell, 1996; Tůma et al., 2006; Mishra et al., 2021). However, the problem occurs when these supplies are disrupted or fail. This is followed by a cascading effect, the result of which is not only a reduction in the comfort we expect, but above all a reduction or even a direct threat to our interests and protected values (Mahdavian et al., 2020). The key importance of electricity is also confirmed by its classification as a critical infrastructure (Sonesson et al., 2021; Osei-Kyei et al., 2021) at the level of most developed countries in the Euro-Atlantic area (including the Czech Republic), as it is a prerequisite for all other segments. In the event of a long-term power outage, the supply of other commodities (water, gas, heat, oil), production (industry) and all services (health care, food supply, telecommunications services, etc.) may be gradually reduced or completely stopped (Haes Alhelou et al., 2019). For this reason, one of the basic conditions for the security of the state is to strengthen the security of electricity supply, including resilience in the event of a potential outage.

\section{The importance of the energy sector}

From the point of view of a comprehensive concept, it is necessary to perceive the importance and position of the energy sector in the following several levels, which, however, are very closely interconnected.

Geopolitical level - Energy security is not only a strategic, but above all a political and security issue that has accompanied our society since the beginning of its existence. The goal of each state is to provide the necessary energy and raw material resources, which are the main condition for its economic stability and growth. Therefore, in order to ensure energy security, various means are used from standard trade relations, diplomatic agreements to extreme negotiations in the form of armed conflicts. An illustrative example of this extreme solution is the Cold War, where a number of wars were caused by the desire to control energy resources (Operation Desert Storm 1991 and Iraqi Freedom 2003). A fundamental precondition here is the geographical location of the state where these resources are located, or their transit areas. According to the realistic view of some authors, energy security is a set of ever-increasing problems. This view is based on the assumption that individual states will use all their instruments of power at their disposal as part of their foreign policy to promote their interests. The reason for this is the distrust of the current form of the raw materials market and the possibility of securing long-term reliable supplies. Their argument is based on the current state of the world, which is full of terrorism and conflicts between the West and Islamic countries. In addition, where more than three quarters of the world's energy reserves are located in Muslim countries (Luft, Korin, 2009) that individual states will use all their instruments of power at their disposal as part of their foreign policy to promote their interests. The reason for this is the distrust of the current form of the raw materials market and the possibility of securing long-term reliable supplies. Their argument is based on the current state of the world, which is full of terrorism and conflicts between the West and Islamic countries. In addition, where more than three quarters of the world's energy reserves are located in Muslim countries (Luft, Korin, 2009) that individual states will use all their instruments of power at their disposal as part of their foreign policy to promote their interests. The reason for this is the distrust of the current form of the raw materials market and the possibility of securing long-term reliable supplies. Their argument is based on the current state of the world, which is full of terrorism and conflicts between the West and Islamic countries. In addition, where more than three quarters of the world's energy reserves are located in Muslim countries (Luft, Korin, 2009)

National level - the priority of each state is to fulfill its national policy, which consists primarily in ensuring its sovereignty, territorial integrity, economic and social development, including the protection of the health and lives of its citizens. The energy sector is also an integral and important part of this policy. Its main goal is to create suitable conditions for sufficient and sustainable domestic production of products and services with regard to the size of expected consumption. These conditions must be ensured not only in the current period, but also in the event of crisis situations. In the context of the national level, the role of the energy sector can be perceived from the perspective of the whole society or from the perspective of the individual and his individual needs.

$>$ Social aspect - the aim of this aspect is to ensure the operation of the energy sector for society as a whole. This view can also be called macroeconomic. Its purpose is to ensure energy supplies for all production activities and services provided in all branches of human activity, which are located in 
the territory of the state and which are dependent on these supplies. If these supplies are not secured, these activities will be limited or stopped, which will result in economic and subsequently social stagnation, which in the long-term absence can lead to destabilization across all segments in such territory (Hromada, Fröhlich, 2019).

$>$ Individual point of view - the aim of this aspect is to secure energy supplies for the final consumer. This view can also be called microeconomic. Its purpose is to satisfy the individual needs of the individual, which are based on the availability of products and services dependent on energy supply. Their absence results in a reduction in the expected comfort, and if they last longer, it can lead to a threat to its physiological functions. Damage to the human psyche is also a very dangerous and undesirable consequence. During the long-term effect of such a situation, there is a strong stressful and aggressive behavior of individuals, which gradually grows into non-respect of social norms due to the prevalence of soil behavior. In the event that the operation of the infrastructure is resumed within 24 hours, the situation is manageable from the point of view of protecting the population and maintaining public order. Otherwise, it can be assumed that after a few days, social communities will begin to disintegrate and citizens will take their destiny and right into their own hands in order to provide for the needs of their loved ones without any regard for legal or other norms. The key role here is also played by ensuring that the population is sufficiently informed about the current state of the situation, the method of solution and the prediction of future development.

Although the individual aspects mentioned above pursue different incentives and goals, they are all based on a common and key starting point. This starting point is security or ensuring a reliable and highquality supply of electricity to the final consumer.

\section{Blackout - a threat not only of the 21st century}

Power outages can vary in duration and extent. In terms of frequency of occurrence, we most often encounter local and short-term power outages. This condition usually lasts several minutes or tens of minutes and does not pose a significant danger from the point of view of both society and the individual. Today, most important operations, as well as citizens, are prepared for this situation and equipped to replace it with alternative sources of electricity (in the form of UPS batteries, power plants, etc.). A diametrically different situation occurs when there is an extensive and long-term power outage or socalled blackout. This is undoubtedly the worst variant of a power system failure, which also represents one of the biggest threats to the present and the future. In principle, this failure means a disturbance of the balance power balance, which goes beyond resource regulation. Therefore, if the difference between the immediate produced and consumed power cannot be eliminated immediately by using support services, operational interventions of dispatchers and with the help of other pre-prepared measures, nonstandard changes in frequency, power and usually voltage fluctuations will appear in the power system. Due to variously fast changes in frequency and voltage above the standard limits, the frequency and voltage protections will act, ie consumption and production will be disconnected. non-standard changes in frequency, power and usually voltage fluctuations begin to manifest in the electrical system. Due to variously fast changes in frequency and voltage above the standard limits, the frequency and voltage protections will act, ie consumption and production will be disconnected. non-standard changes in frequency, power and usually voltage fluctuations begin to manifest in the electrical system. Due to variously fast changes in frequency and voltage above the standard limits, the frequency and voltage protections will act, ie consumption and production will be disconnected.

The interconnected transmission system disintegrates, causing a subsequent "domino" effect that transmits the balance collapse to lower voltage levels. The end result will be the disconnection of all sources from the affected part of the electricity system and the voltage-free state at all voltage levels in this part of the electricity system. In the literature we can find different definitions of this phenomenon. From a technical point of view, blackout is perceived as a moment of disturbance of the balance between the production and consumption of electricity and as a result there is a threat to the reliability of supply of this commodity (Silvast, Kaplinsky, 2007). In general, a blackout is a complete power outage (Bruch et al., 2011). Pursuant to Commission Regulation (EU) 2017/1485 laying down guidelines for the operation of electricity transmission systems 
According to the severity, which is determined by the time range of power failure, it is possible to divide the blackout into three degrees (Beneš, 2015):

$>$ First degree blackout - it is a several-hour breakdown of the operation of the electricity system, without subsequent damage or only with minor destruction, which is quickly repairable. First-degree blackouts can occur due to an imbalance in electricity generation and consumption (for example, in the absence of ancillary services to ensure network stability in the event of a sudden increase in wind power output in northern Europe). The elimination time of such a blackout and the resumption of operation of the electricity system should be a matter of a few hours.

$>$ Second degree blackout - it is a breakdown of the electricity system, the duration of which is in the order of days, or one to two weeks. Its length depends on the complexity of the destruction. A typical case is blackout caused by extreme hydrometeorological phenomena. These are usually storms and hurricanes that can cause trees to fall on power lines, or directly destroy the power system poles, or extreme icing, which can also cause power lines to be pulled down. If more than one critical element of the electricity system is damaged (decommissioned), the repair of damaged lines or other components and the commissioning of the electricity supply can take several days to weeks.

$>$ Third degree blackout - the duration of this condition exceeds the limits of the previous stage. The breakdown of the electricity system would take more than two weeks. The third degree blackout can be caused by an intentional act, which eliminates those elements of the electricity system, the repair or production and replacement of which takes months. Transformers are an example of such an element. These are costly, high-performance devices that are not easy to manufacture, transport and replace.

One of the main and at the same time effective measures that lead to the minimization of the effects of blackout is the system of island operation (Marín-Jiménez et al., 2019). Island operation means the separation of a separate part of the electricity system that operates independently of this system (Máslo, Kolcun, 2014). The purpose of this measure is to create and ensure operation using local resources located directly in the affected area, or. its surroundings, which will be able to function until the entire electricity system can be restored. The decisive factors for the implementation of the island operation include not only the availability, but also the technical readiness of all involved components and entities for such operation. The common result is a limited supply of electricity to selected consumers in a crisis situation. This method of supply does not ensure the supply of electricity for the affected area in full, but is designed to maintain the minimum operational operation of the most important elements that provide the basic needs of its population in the area (Burdek, 2019; Čerňan et al., 2020). From a technical point of view, this measure does not represent any significant novelty for the current professional society. However, the weak point of this measure remains in the level of planned procedural preparation of the territory. Especially in the way of determining the preferences of individual elements on the part of end consumers. This problem consists in the systematic and objective definition of key consumption points (so-called safety-relevant objects), which will be included in the island operation. which provide for the basic needs of its population in a given area (Burdek, 2019; Čerňan et al., 2020). From a technical point of view, this measure does not represent any significant novelty for the current professional society. However, the weak point of this measure remains in the level of planned process preparation of the territory. Especially in the way of determining the preferences of individual elements on the part of end consumers. This problem consists in the systematic and objective definition of key consumption points (so-called safety-relevant objects), which will be included in the island operation. which provide for the basic needs of its population in a given area (Burdek, 2019; Čerňan et al., 2020). From a technical point of view, this measure does not represent any significant novelty for the current professional society. However, the weak point of this measure remains in the level of planned procedural preparation of the territory. Especially in the way of determining the preferences of individual elements on the part of end consumers. This problem consists in the systematic and objective definition of key consumption points (so-called safety-relevant objects), which will be included in the island operation. Especially in the way of determining the preferences of individual elements on the part of end consumers. This problem consists in the systematic and objective definition of key consumption points (so-called safetyrelevant objects), which will be included in the island operation. Especially in the way of determining the preferences of individual elements on the part of end consumers. This problem consists in the 
systematic and objective definition of key consumption points (so-called safety-relevant objects), which will be included in the island operation.

\section{Methodological approach to territorial security assessment \\ 3.1 Background}

Society in the narrowest sense is a diverse group of people living in groups that are interconnected in a common, defined and demarcated territory controlled by political power. These people share basic common values, follow common norms and behave according to established cultural patterns (Petrusek, 2018). The goal of every company is to strive for its overall development and to meet the basic needs of its members. These needs may vary not only depending on the area inhabited, but also on the nature and developmental stage of the society. The need itself is generally understood to mean the manifestation of a deficiency, the elimination of which is desirable for a person. If the need is not met in the long run, a situation may arise as the suffering of individuals and, worse, the suffering of society as a whole (Rosenfeld et al., 1992). The pyramid of needs is the basic orientation aid in defining the basic needs of the individual and thus of the whole society. Its author ranks human needs in the individual floors of the pyramid according to their importance. The most important and therefore the most basic needs are listed at the lowest level. These needs serve to ensure the very existence of man. If these needs are met, one begins to feel the need to satisfy the needs at the higher levels of this pyramid. All needs are divided into the following five areas (pyramid floors), which are then ranked from lowest to highest (Maslow, 1943): The most important and therefore the most basic needs are listed at the lowest level. These needs serve to ensure the very existence of man. If these needs are met, one begins to feel the need to satisfy the needs at the higher levels of this pyramid. All needs are divided into the following five areas (pyramid floors), which are then ranked from lowest to highest (Maslow, 1943): The most important and therefore the most basic needs are listed at the lowest level. These needs serve to ensure the very existence of man. If these needs are met, one begins to feel the need to satisfy the needs at the higher levels of this pyramid. All needs are divided into the following five areas (pyramid floors), which are then ranked from lowest to highest (Maslow, 1943):

$>$ Physiological needs - these are the basic needs of the human body (eg: breathing, drinking, excretion, physical activity, housing, heat, light, space, sleep, reproduction, etc.).

$>$ The need for safety and security - at a time when the above physiological needs are relatively met, there is an increase in safety and security needs (eg: physical security, health security, family security, job security, access to resources, well - being, emergency assistance, etc.) .

$>$ The need for belonging - after the fulfillment of physiological needs and security needs comes social needs (eg: friendship, partnership or the need to have a family, etc.).

$>$ The need for recognition - All people need to be respected, which includes the need to have adequate self-esteem and to succeed. Respect and recognition represent a typical human need to be accepted, valued and respected by others. Satisfying these needs leads to a sense of confidence and prestige.

$>$ The need for self-realization - in the last phase, it is an instinctive need to fulfill your abilities and strive to be the best person. One wants to fully realize one's talents and abilities.

It can be stated that the lowest or the first two mentioned floors of this pyramid represent the needs necessary for human life, while the remaining upper floors affect his quality (Maslow, 1943). The primary effort of every company is to ensure the safety of the needs of these lowest levels, which is significantly reflected especially in crisis situations. Only then is it possible to satisfy the needs of others.

Today's modern society is fully dependent on the flawless functioning of individual elements of infrastructure, which ensure the satisfaction of their needs. Some of these infrastructures are even marked as critical. However, the concept of critical infrastructure is clearly conceived by a centralist approach from the point of view of the state, or European Union. However, as a result of this approach, the position and needs of lower territorial units, which may be regions or even municipalities themselves, are completely neglected. It should be borne in mind that even these levels have the infrastructure on their territory that is specific to them, indispensable and absolutely essential in overcoming the effects of crisis situations. However, its composition may not always be completely identical to the concept of national or even transnational critical infrastructure. The reason for this dual view lies in the different needs and related priorities of the territory and its inhabitants. An illustrative example of this disparate 
perception is medical facilities with a small number of acute beds (eg up to 200 beds), which do not have an established emergency room. From the global point of view of the state in the provision of health care, this facility is not an element of critical infrastructure, as its capacity is negligible and the facility is relatively easy to replace. On the other hand, from the perspective of the municipality in which this facility is located, it is an infrastructure that is absolutely crucial for this area and its population. which do not have an urgent reception set up. From the global point of view of the state in the provision of health care, this facility is not an element of critical infrastructure, as its capacity is negligible and the facility is relatively easy to replace. On the other hand, from the perspective of the municipality in which this facility is located, it is an infrastructure that is absolutely crucial for this area and its population. which do not have an urgent reception set up. From the global point of view of the state in the provision of health care, this facility is not an element of critical infrastructure, as its capacity is negligible and the facility is relatively easy to replace. On the other hand, from the perspective of the municipality in which this facility is located, it is an infrastructure that is absolutely crucial for this area and its population.

In order to systematically and unambiguously define the basic needs for a specific area in relation to the threat of disruption of electricity supply, a model for assessing the security of the area was proposed. This model is based on two basic pillars, namely the process of identification and evaluation of safetyrelevant objects in the area. The aim of this model is to objectively assess and help define areas, including their infrastructural representation, which are necessary to ensure security in the area, including the setting of their priorities.

\subsection{Identification of safety-relevant objects}

The starting point for determining security-relevant objects is knowledge of the processes and activities that provide these objects. The main benefit of this approach lies primarily in its maximum possible objectivity, complexity and, above all, the ability to capture the relevant links and contexts. An illustrative example of a process approach can be demonstrated in the area of ensuring the supply of drinking water. One of the important facilities for ensuring the supply of drinking water to the final consumer is the water treatment plant. In this building, drinking water is produced from raw water, which is taken directly from the water source. However, the operation of this building will not in itself ensure the supply of drinking water. It is necessary that at the same time as the treatment plant operates, the operation of other facilities involved in the supply of this medium is ensured, such as pumping and pumping stations, reservoirs, etc. Only as a result of ensuring the operation of all necessary facilities within the entire process of ensuring the supply of drinking water is it possible to transport drinking water of the required quality to its destination, ie to the final consumer. This example clearly shows the need for process knowledge of the entire breadth of the research area, as a result of which it is only possible to define the actual security requirements and then determine the safety-relevant objects for the area. For this reason, the presented model for assessing the security needs of the area is based on a process approach. as a result of which it is only possible to define the actual security requirements and subsequently to determine the safety-relevant objects for the area in question. For this reason, the presented model for assessing the security needs of the area is based on a process approach. as a result of which it is only possible to define the actual security requirements and subsequently to determine the safety-relevant objects for the area in question. For this reason, the presented model for assessing the security needs of the area is based on a process approach.

\subsection{Evaluation of safety-relevant objects}

Based on the performed identification, we obtain a set of safety-relevant objects for the evaluated area. All objects in this set are equivalent. However, from the point of view of satisfying the basic needs of the population in the event of a power failure, this principle of parity is insufficient. The main shortcomings of this principle include disrespect for interdependencies between individual objects and especially the absence of perception of social preference of individual needs in relation to maintaining the integrity of the individual in the immediate threat to his life and health in real time. The need to satisfy individual needs always arises gradually and depends on the course of the crisis situation and the company's ability to withstand its effects. For these reasons, an integral part of the proposed model is the method of evaluating this set of security-relevant objects, whose aim is to set a clear order of their priorities in ensuring the basic needs of the population and related functions of the territory. Due to the 
fact that it is always necessary to carefully consider several aspects at the same time when assessing safety, an approach based on the method of multicriteria decision-making was chosen. It is a method of operational research that is used when deciding between multiple variants. These variants are expressed in the form of evaluation criteria. At the same time, however, the individual evaluation criteria are of varying degrees of importance. This different degree of importance can be demonstrated on a model example from the healthcare sector. There may be several medical facilities in the evaluated area at the same time, while not all of them are equally important from the point of view of ensuring life and health. Some only provide outpatient care, some urgent admission, some acute inpatient care, some only aftercare, etc. From this simple example, it is clear that it is necessary to set rules for determining the priorities of these facilities. The subject of the assessment is therefore the individual security-relevant objects and the final result is the determination of their priority order in terms of ensuring the security of the area in relation to the threat.

\section{Conclusion}

Blackout, or large-scale power outages, is one of the biggest security threats to today's world. The essence of the danger arising from this threat lies mainly in the seriousness of the impacts, which, without exception, cascading and fundamentally disrupt all economic and social areas of our society. The unique position of this threat stems from the fact that electricity is a key and at the same time essential commodity for all of us, both in the performance of work activities and in leisure activities. This methodological approach provides a solution to determine the basic set of necessary needs in the area before the threat of a major power outage. These needs are then prioritized in relation to maintaining the integrity of the individual in real time, by defining their infrastructural provision in the form of socalled safety-relevant objects. The output in the form of a clear and prioritized list of safety-relevant objects subsequently serves as a basis for energy companies, who according to these priorities direct the flow of available electricity in the event of a crisis within the island operation or similar measures in the area. In addition to the primary use for the preparation of island operations, this methodological approach can also be applied in the process of resumption of supplies from the public network after a massive outage. who, according to these priorities, regulate the flow of available electricity in the event of a crisis situation within the framework of island operation or similar measures in the given territory. In addition to the primary use for the preparation of island operations, this methodological approach can also be applied in the process of resumption of supplies from the public network after a massive outage. who, according to these priorities, regulate the flow of available electricity in the event of a crisis situation within the framework of island operation or similar measures in the given territory. In addition to the primary use for the preparation of island operations, this methodological approach can also be applied in the process of resumption of supplies from the public network after a massive outage.

The paper was prepared within the project VI3VS / 689 entitled "Increasing the resilience of the region to the threat of widespread power outages using new technologies and crisis management procedures." This project is implemented with the financial support of the Ministry of the Interior, within the security research program of the Czech Republic 2015-2022 (BV III / 1-VS).

\section{Literature}

BELL, D., (1996). The Cultural Contradictions of Capitalism. New York: Basic Book. 400 pp. ISBN: 9780465014996.

BENEŠ, I. (2015). Resistance to blackout - a fundamental pillar of human security [online]. National Security Institute, 2015, 8 July 2015 [cited. 2021-10-09]. Available from WWW: <http://vypadekelektriny.cz/odolnost-proti-blackoutu-zakladni-pilir-lidske-bezpecnosti>.

BRUCH, M., MÜNCH, V., AICHINGER, M., KUHN, M., WEYMANN, M., SCHMID, G., (2011). Power Blackout Risks [online]. CRO FORUM. November 2011 [cit. 2021-10-09]. Available from WWW: 〈https://www.preventionweb.net/files/24128_powerblackoutrisks1.pdf>.

BURDEK, Z., (2019). Blackout and Island Operations [online]. TZB-info, 2019, 10. 10. 2019 [cit. 2021- 
10-09]. Available from WWW: <https://energetika.tzb-info.cz/elektroenergetika/19683-blackout-aostrovni-provozy>.

ČERŇAN, M., MÜLLER, Z., TLUSTÝ, J., HALAŠKA, J., (2020). Methodology of Electricity Supplying of Critical Infrastructure in Crisis Situations. 21st International Scientific Conference on Electric Power Engineering (EPE), pp. 1-5. DOI 10.1109 / EPE51172.2020.9269257.

HAES ALHELOU, H., HAMEDANI-GOLSHAN, ME, NJENDA, TC, SIANO, P., (2019). A Survey on Power System Blackout and Cascading Events: Research Motivations and Challenges. Energies, vol. 12, no. 4. ISSN 1996-1073. DOI 10.3390 / en12040682.

HROMADA, M., FRÖHLICH, T., (2019). Starting points for ensuring a stable supply of electricity. The Science For Population Protection, vol. 11, no. 12, pp. 1-13. ISSN 1803-568X.

LUFT, G., KORIN, A., (2009). Energy security challenges for the 21 st century: a reference handbook. Santa Barbara, Calif. : Praeger Security International. 372 pp. ISBN 978-0275999971.

MAHDAVIAN, F., PLATT, S., WIENS, M., KLEIN, M., SCHULTMANN, F., (2020). Communication blackouts in power outages: Findings from scenario exercises in Germany and France. International Journal of Disaster Risk Reduction, vol 46. ISSN 2212-4209, DOI 10.1016 / j.ijdrr.2020.101628.

MARÍN-JIMÉNEZ, JD, CARVAJAL-QUINTERO, SX, SANTIAGO ARANGO-ARAMBURO, S., (2019). Implementation proposal for an ancillary service for Island Operation Capability in Colombia: A system dynamics approach. International Journal of Electrical Power \& Energy Systems, vol. 113, pp. 288-297. ISSN 0142-0615. DOI 10.1016 / j.ijepes.2019.05.035.

MASLOW, AH, (1943). A Theory of Human Motivation. Psychological Review, vol. 50, no. 4, pp. 370369.

BUTTER, K., KOLCUN, M., (2014). Load - frequency control management in island operation. Electric Power Systems Research, vol. 114, pp. 10-20. ISSN 0378-7796. DOI 10.1016 / j.epsr.2014.03.030.

MISHRA, DK, GHADI, MJ, AZIZIVAHED, A., LI, L., ZHANG, J., (2021). A review on resilience studies in active distribution systems. Renewable and Sustainable Energy Reviews, vol. 135. ISSN 1364-0321. DOI 10.1016 / j.rser.2020.110201.

COMMISSION REGULATION (EU) 2017/1485 of 2 August 2017 laying down a framework guideline for the operation of electricity transmission systems.

OSEI-KYEI, R., TAM, V., MA, M., MASHIRI, F., (2021). Critical review of the threats affecting the building of critical infrastructure resilience. International Journal of Disaster Risk Reduction, vol 60. ISSN 2212-4209. DOI doi.org/10.1016/j.ijdrr.2021.102316.

PETRUSEK, M., (2018). Society - Sociological Encyclopedia [online]. Institute of Sociology AS CR, vvi, 2018, 10. 11. 2018 [cit. 2021-10-09]. Available from WWW: <https://encyklopedie.soc.cas.cz/w/Spole\%C4\%8Dnost>.

ROSENFELD, P., CULBERTSON, A., MAGNUSSON, P., (1992). Human needs, a literature review and cognitive life span model [online]. Navy Personnel and Development Center. Program Element 0603707N, 1992 [cit. 2021-10-09]. Available from WW: <https://apps.dtic.mil/sti/pdfs/ADA250073.pdf>.

SILVAST, A., KAPLINSKY, J., (2007). White Paper on Security of European Electricity Distribution. UNDERSTAND research project funded by the European Union. $63 \mathrm{~s}$.

SONESSON, TR, JOHANSSON, J., CEDERGREN, A., (2021). Governance and interdependencies of critical infrastructures: Exploring mechanisms for cross-sector resilience. Safety Science, vol. 142. ISSN 0925-7535. DOI 10.1016 / j.ssci.2021.105383.

TŮMA, J., RUSEK, S., MARTÍNEK, Z., CHEMIŠINEC, I., GOŇO, R., (2006). Reliability in power engineering. Prague: Conte. 291 pp. ISBN: 80-239-6483-6. 
DOI: 10.36682/SSS_2021_5

\title{
PhDr. Vladimíra Hudecová
}

\author{
Katedra: Katedra správneho práva Department: Administrative Law \\ Univerzita: Akadémia Policajného zboru v Bratislave University: Academy of the Police Force in Bratislava \\ $\triangle$ Sklabinská 1835 17, Bratislava, Slovak Republic \\ E-mail: vladimira.hudecova@akademiapz.sk
}

\begin{abstract}
Anotace
The aim of the article is to refer to the EU road safety policy, which can positively influence the policy direction of individual member states. Although the level of responsibility for specific road safety actions is equally shared between the EU and individual Member States, EU action in this area is more than desirable. The harmonization of road traffic rules and the establishment of common procedures for sanctioning infringements can be included among the important prospects for reducing the number of victims on all EU roads. The article is the result of a scientific research task, which was part of the project "Analysis of transport systems for protection of persons and property with emphasis on the eCall project", covered by the Academy of the Police Force in Bratislava in 2015. The applied methods are based on the research of the literature, analysis of the knowledge gained through direct participation in webinars conducted by the European Commission, guided interviews with experts from practice. The output of the paper is a general overview of the issue in the context of current legislation.
\end{abstract}

\section{Key words}

Road Safety; Traffic Offences; Exchange of Information

\section{Introduction}

An important consequence of transport sustainability will be the improvement of the traffic safety. Among important factors, which create the improvement of the traffic safety may be included modern vehicles, equipped with a large number of electronic devices, secondly the modern and efficient infrastructure, and at least, but not last appropriate and effective legislation (Dirnbach, Kubjatko, Kolla, Ondruš, Saric, 2020).

Increasing road safety has been part of the EU agenda for decades. The latest EU thematic documents state targets of the "EU Road Safety Policy Framework 2021-2030" with the sub-heading "Next steps towards Vision Zero". This document outlines specific political action planned for the years 2021-2030, and builds on the EU Strategic Action Plan on Road Safety issued in May 2018. Significant factors affecting the level of road safety, particularly in quantitative terms, include traffic offences which, due to their cross-border scope, affect the road traffic of all member states. The share of responsibility for specific road traffic safety actions between the EU and individual member states is the same; however, road traffic policies at the EU level can positively shape the policy direction of individual member states It is clear that problems relating to road safety are equal in all EU member states, and EU bodies are fully aware of the ways in which they can help domestic governments through cooperation and the exchange of information.

The harmonisation of road traffic rules and the establishment of common procedures for imposing sanctions for infringements can be counted among promising tools for reducing the number of victims on all roads in the EU. The EU road safety programme is continuously developing. In 2011, the EU began working on a specific measure aimed at responding, in a targeted manner, to the necessity to develop a comprehensive legal basis for strengthening cross-border cooperation of police forces for 
dealing with traffic offences. Directive (EU) 2015/413 of the European Parliament and of the Council of 11 March 2015 facilitating cross-border exchange of information on road-safety-related traffic offences introduces a new type of modern and automated exchange of information between police forces about road users who fail to comply with applicable road traffic rules in member states in which they do not reside.

\section{The Direction of EU Road Safety Policy}

According to the European Commission, the number of road deaths dropped by $2 \%$ in 2019. In 2019, approximately 22,800 victims were recorded on roads in the $28 \mathrm{EU}$ member states. This is almost 7,000 fewer deaths in comparison with 2010, which can be expressed as a $23 \%$ decline. Compared to 2018, the number fell by $2 \%$. While the basic trend continues to decline, progress in most countries has slowed down since 2013, and the EU hasn't met the goal to reduce the number of road deaths by half by 2020 (compared to the starting value from 2010). Although assessments for 2020 predicted a decline in fatal road accidents, the circumstances brought about by the fight against corona virus were expected to have a greater impact on this decline (Frej, Ludwinek, 2020).

Each previous period of the EU struggle to influence the number of road deaths could be assigned by following headings: „2013-2018, A Period of Stagnation“, „2016, A Third Bad Year“, „2017, The Valletta Declaration“", „2010-2020, A Time of Unfulfilled Goals“, „2021-2030 (and up to 2050) A New Vision Zero“ and finally „2020, The Stockholm Declaration and Key safety performances indicators (KPI)“.

\section{Safe road use - 2021}

The newest part of the Europe on the Move package based on the Strategic Action Plan, proposed by the European Commission sets of themes for combating the largest road safety challenges, namely: 1. infrastructure safety; 2 . vehicle safety; 3 . safe road use including speed limit compliance, sober driving (without alcohol or drugs), undistracted driving, and the use of protective equipment; 4. emergency response.

"Safe road use" has been labelled as the third pillar in the prevention of road fatalities and serious injuries. Its specificity mainly stems from the fact that the human factor plays a key role in the observance of its principles. Although the agenda for improving the behaviour of road users is primarily the responsibility of the member states, the EU has decided to partially intervene in the development of this area by adopting legislation that intends to help all member states reduce fatalities and injuries, as well as property damage. This step can be more precisely identified as a new form of cooperation between police forces aimed at dealing with traffic offences.

Since the road safety is a very broad topic, it contains not only the technical safety of vehicles, but also the safety of the entire transport infrastructure, the behaviour of drivers (Arshad, Jantan, Abiodun, 2018) their skills, psyche. The documentation of traffic accidents (Böhm, Kubjatko, Paula, Schweiger, 2020), their subsequent analysis (Dirnbach, Kubjatko, Kolla, Ondruš, Saric, 2020), identification of causes (Kubjatko, Görtz, Macurova, Ballay, 2018) and adequate retrospective measures become crucial. In the future, it is a question of the security of digitization and data communication of vehicles, autonomous vehicles, intelligent transport systems, etc. Security education plays another important role (Kopencova, 2020). It is important to note, that the road safety is also often associated with a country's economic development (Rak, 2020).

\section{The path of a targeted legislation}

EU has intended to help all member states reduce fatalities and injuries by the adoption of the Directive 2011/82/EU of the European Parliament and of the Council of 25 October 2011 facilitating the crossborder exchange of information on road-safety-related traffic offences (hereinafter referred to as "Directive 2011/82/EU") in force from November 2013 (until May 2015), which could be defined as an essential pillar of cooperation between police forces of EU states targeting traffic offences.

\subsection{Less traffic offences $=$ Safer roads}


The main reason for adopting this directive was to find a way to deal with road traffic offences committed by vehicles registered in a member state other than the member state in which the offence was committed. The main impetus for the European Commission to develop this measure was the previously mentioned goal set in the European Policy Orientations 2011-2020, which was to "halve the number of road deaths in the EU by 2020 ". The reality on the roads was that in most cases, traffic offences could not be resolved by the police because identifying the driver of a vehicle registered in a different member state was almost impossible, and it was also not possible to verify the address at which the vehicle was registered (Poliak, Tomicová, Jaśkiewicz, 2020).

Prior to the adoption of Directive 2011/82/EU, there was no such instrument which would allow police forces to commence infringement proceedings for an offence committed by a vehicle registered in a different member state. The only existing ways to establish joint proceedings between police forces were Council Decision 2008/615/JHA, Council Decision 2008/616/JHA (the "Prüm Decision"), or the Vienna Convention on Road Traffic of 8 November 1968. However, the legal basis of existing agreements in the field of road safety lies mainly in cooperation covering criminal law, which means that infringement proceedings are not covered in a completely unambiguous manner.

When preparing Directive 2011/82/EU, the European Commission proceeded based on the fact that although so-called non-resident drivers account for specifically $5 \%$ of road users, this same group of drivers accounts for up to $15 \%$ of speeding offences. It also pointed out that drivers of foreign vehicles are up to three times more likely to commit traffic offences than resident drivers. In France, for example, where there is a high level of transit and tourism, speeding offences committed by non-resident drivers may account for $25 \%$ of the total number of offences, while at very busy times of year, this number may reach $40 \%$ to $50 \%$. In this regard, the positive impacts of the new legislation should be especially interesting for countries like Austria, Belgium, Luxembourg, France, Germany, Hungary, Italy, Poland and Spain. The new legislation should have a powerful deterrent effect, or more precisely should motivate drivers to observe the traffic laws applicable in their host country (Stanczyk, Jurecki, Jaskiewicz, Frej, Lagowski, Zuska, 2020).

\subsection{The Directive facilitating cross-border exchange of information}

The objective of Directive 2011/82/EU was defined in Article 1 as the intention to ensure a high level of protection for all road users in the EU by facilitating the cross-border exchange of information on road-safety-related traffic offences (or road-safety-related criminal traffic offences) and thereby the enforcement of sanctions in which the offences are committed with a vehicle registered in a member state other than the member state where the offence took place. The scope of this directive specified in Article 2 covers the following road-safety-related traffic offences: 1 .) speeding; 2 .) non-use of seatbelt; 3.) failing to stop at a red traffic light; 4.) drink-driving; 5.) driving under the influence of drugs; 6.) failure to wear a safety helmet; 7.) use of a forbidden lane; 8.) illegally using a mobile telephone or any other communication devices while driving. The directive does not aim to harmonise the nature of infringements, nor the type of sanctions imposed. Offences shall be assessed, and sanctions imposed under the national law of the country where an offence is committed. The directive only addresses financial penalties; it does not deal with proceedings related to driving licences and the revocation of licences.

\subsection{Change of the legal basis}

In January 2012, after Directive 2011/82/EU was adopted, the European Commission took legal action against the European Parliament and the Council for the annulment of the directive. By its application, the European Commission requests the court, first, to annul Directive 2011/82/EU and, second, should it annul that directive, to state that its effects are to be considered as definitive. The European Council mainly argued that Article 87(2) of the TFEU was not the correct legal basis for adopting the directive. That provision, which covers police cooperation between the competent services in relation to the prevention, detection and investigation of "criminal offences", may only be used as a legal basis for measures specifically related to the prevention or detection of "criminal offences". Thus, it cannot be inferred simply because an "offence" is punitive in nature or seeks to be a successful deterrent, automatically be regarded as a "criminal" offence within the meaning of Article 87 of the TFEU. That 
being so, the European Commission considers that both the goal and the content of Directive 2011/82/EU fall within the field of transport policy and, in particular, of Article 91 of the TFEU, which should therefore have been used as the legal basis of that directive.

By its judgement of 6 May 2014 in case SC-43/12, the Court of Justice ultimately ruled: 1. to annul Directive 2011/82/EU of the European Parliament and of the Council of 25 October 2011 facilitating the cross-border exchange of information on road safety related traffic offences;

2. to maintain the effects of Directive 2011/82/EU until the new directive will enter into force;

3. that the European Parliament and the Council of the European Union shall pay the costs of the proceedings;

4. that the Kingdom of Belgium, Ireland, Hungary, the Republic of Poland, the Slovak

Republic, the Kingdom of Sweden and the United Kingdom of Great Britain and

Northern Ireland shall bear their own costs.

With regard to the above, it should be noted that Directive 2011/82/EU remained in force for the duration of the proceedings on the legitimacy of its legal basis, which lasted approximately a year from its effective date. One of the important benefits of addressing the change in the legal basis of the directive was the expansion of the number of member states which, under the legal basis of Article 87(2) of the TFEU, could apply the derogation regime to police cooperation (the United Kingdom and Ireland could apply to opt-in within the meaning of Protocol 21 of the TFEU, and Denmark could apply to opt-out within the meaning of Protocol 22 of the TFEU), which meant that the proposed directive did not apply to three member states.

By introducing the new Directive (EU) 2015/413 of the European Parliament and of the Council of 11 March 2015 facilitating the cross-border exchange of information on road-safety-related traffic offences (hereinafter referred to as "Directive 2015/413") the member states intended to replace Directive 2011/82/EU by May 2015 according to an adjusted legal basis without any changes to the annulled directive (Directive (EU) 2015/413).

\section{Interim results- Automated Exchange of Information}

From the perspective of Police, the main benefit of the new directive lies in the Article 4 of Directive 2015/413, since it allows authorities of member states to access foreign vehicle registration databases via an electronic information systém (Kopencova, Rak, 2020), which makes it possible to identify potential perpetrators of traffic offences who do not have a residence in the particular country in cases where it is not possible to stop the vehicle or to identify the driver. After identifying a person suspected of committing a road-safety-related traffic offence (such as speeding or failing to wear a seatbelt), the member state in which the offence was committed shall make a decision on the initiation of proceedings. The directive specifies the manner in which the offence should be notified to the person concerned, and provides a (non-obligatory) model letter. This letter should be written in the same language as the vehicle registration document from the database or in one of the official languages of the member state in which the vehicle is registered.

\subsection{European Car and Driving Licence Information System}

In matters of automated information exchange, the implementation of Directive 2015/413 was based on the use of an already existing platform for the exchange of data on vehicles and vehicle owners/holders, the European Car and Driving Licence Information System (EUCARIS). In the interest of clarity, it should be noted that EUCARIS was originally created as an information system for exchanging information on vehicles and driving licences from the national registers of EU member states, who used it based on the EUCARIS Treaty. (Rak, Zrubak, 2012).

EUCARIS later became an EU technical platform for dealing with exchanges of information on vehicles, vehicle holders/owners, and driving licences based on adopted EU legislative act.

The functioning EUCARIS system does not act as a central database but as a system that allows participating countries to enter the vehicle registers and driving licence registers of other participating 
countries. Each participating country remains responsible for its own national records. EUCARIS is only a central node for the electronic exchange of road transport data.

\subsection{Slovakia and the module „CBE“}

Slovakia transposed the original Directive 2011/82/EU by amending Act No. 8/2009 Coll., on road traffic. In Slovak conditions, EUCARIS was functional at the time of the implementation of the directive in two modules - the EUCARIS module (vehicles and driving licences) from 25 September 2013, and the Prüm module from 2 December 2013. The module designated for the automated exchange of information pursuant to Directive 2015/413 was given the name CBE (cross-border enforcement), and Slovak Republic launched its productive operation on 26 August 2014.

The data provided by the Department of Documents and Registers of the Presidium of the Police Force (Figure 1) show that the citizens of the Slovak Republic committed in 2019 high number of traffic offenses in Austria, the Czech Republic, Hungary, Italy and Germany. The authors of this article believe that regular publication of these data may preventively effect the behaviour of drivers. Drivers should be aware of the CBE module capabilities and its ability given to the Police to monitor their behaviour abroad.

\section{Picture 1: Traffic offences of Slovaks}

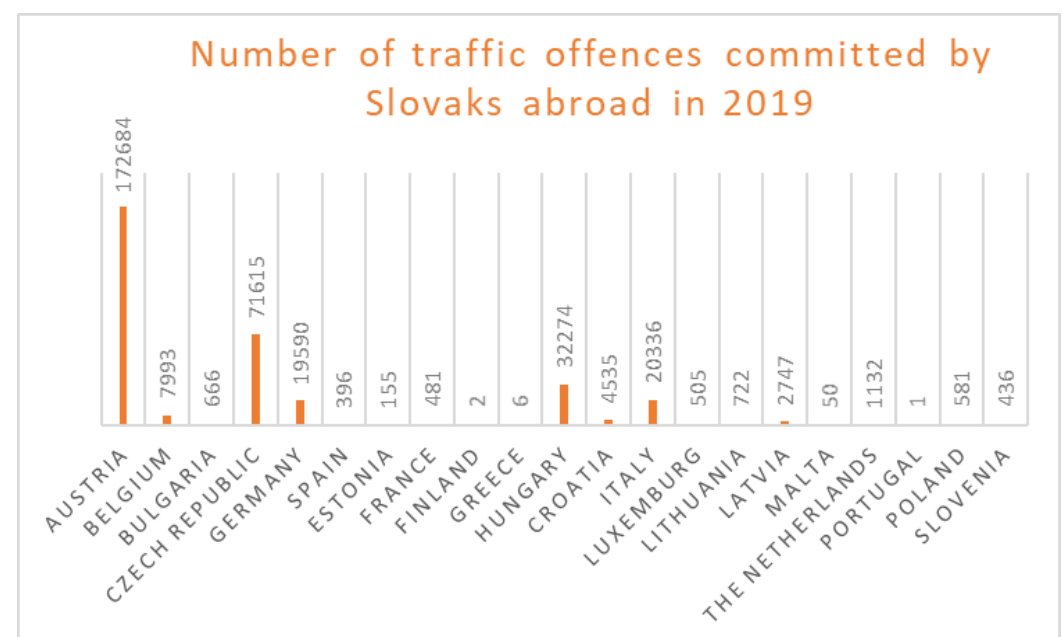

Source: Data provided by the Department of Documents and Registers of the Presidium of the Police Force, Slovakia.

The data provided by the Department of Documents and Registers of the Presidium of the Police Force (Picture 1) show that the citizens of the Slovak Republic committed in 2019 high number of traffic offenses in Austria, the Czech Republic, Hungary, Italy and Germany. The author of this article believe that regular publication of these data may preventively effect the behaviour of drivers. Drivers should be aware of the CBE module capabilities and its ability given to the Police to monitor their behaviour abroad.

Data regarding traffic accidents reveal another possible positive consequence of the Directive 2015/413 and thus, declining trend in traffic accidents from 2015 to 2016 in Slovakia.

\section{Improving the applicability of the Directive}

Since the adoption of either Directive 2011/82/EU or Directive 2015/413, the European Commission has registered hundreds or thousands of notifications of cases from member states where, for various reasons, it has not been possible to recover compensation for traffic offences. For many states, the procedures described in Decision 2005/214/JHA do not appear to be clearly applicable to infringement proceedings (or administrative/government proceedings). 
In 2019, in order to improve the practical applicability of Directive 2015/413, and thereby to make imposed penalties fully enforceable, which would fulfil the primary purpose of this legislative act, the European Commission developed a road-map initiative allowing anyone to comment on their experience with the directive and thereby to complement. the analysis of the impact assessment of the directive. Among other strategies two online seminars were held in June 2020 and January 2021 under the auspices of the European Union with interested parties from the member states who work directly with the directive. Based on the collected comments, the European Commission identified five main problems that member states face in connection with the application of Directive 2015/413:

1. Traffic offences are not investigated due to non-initiation or failure of an investigation.

2. There is insufficient recognition of rulings on financial penalties.

3. There are cases of the violation of fundamental rights and legal principles in road traffic cases where traffic offences are committed by non-residents.

4. There is insufficient information for evaluating the effects of Directive 2015/413.

5. There is insufficient cross-border enforcement of driving disqualifications.

The European Commission has further assessed that many member states request expansion of the scope of Directive 2015/413, particularly the addition of new road traffic offences which are directly or indirectly related to road safety, such as failure to maintain a sufficient distance, dangerous overtaking, dangerous parking, crossing the white line, failure to respect forbidden access, driving in the wrong lane or in the emergency lane, overloading of vehicles, failure to pay parking fees, violation of regulations on access to city vehicles, and failure to pay vehicle insurance. Member states have also pointed out that there is currently no legal instrument at the EU level that would help in the mutual recognition of an imposed driving ban, so that drivers who are banned from driving in their home country cannot drive abroad. For the year 2021, the European Commission has set itself the goal of incorporating all comments of member states into a comprehensive material called an external impact assessment study, which will form the basis for drafting a revision of Directive 2015/413.

\section{Conclusion}

Directive 2015/413 is an important contribution to the area of road safety as it can be defined as an effective tool for police cooperation in the cross-border investigation of (non-resident) traffic offenders. A change in the legal basis for the directive with regard to measures for improving road safety based on Article 91(1)(c) of the TFEU ensures a rapid and secure exchange of data on vehicles and vehicle owners/holders. It represents a tangible effort by the EU both to reduce the number of road deaths and to establish a precautionary measure against non-resident drivers that should motivate them to comply with road traffic rules in "host countries". There is the potential for its positive effects on road traffic safety to be even greater if the number of traffic offences dealt with by the directive is further increased. The harmonisation of traffic offences and the means of dealing with or punishing offenders between the member states could achieve the desired effect.

\section{Literature}

ARSHAD, H., BIN JANTAN, A., ABIODUN, O.I, (2018). Digital Forensics: Review of Issues in Scientific Validation of Digital Evidence. Journal of Information Processing Systems, vol. 14, no. 2, pp 346-376. DOI: 10.3745/JIPS.03.0095.

BÖHM, K., KUBJATKO, T., PAULA, D., SCHWEIGER, H.-G., (2020). New developments on EDR (Event Data Recorder) for auto_mated vehicles. Open Engineering, vol. 10, no. 1, pp. 140-146,. DOI: 10.1515/eng-2020-0007.

Directive (EU) 2015/413 of the European Parliament and of the Council of 11 March 2015 facilitating cross-bor_der exchange of information on road-safety-related traffic offences: https://eurlex.europa.eu/legal-con_tent/EN/TXT/PDF/?uri=CELEX:32015L0413\&from=EN [accessed on 202101-10]. 
DIRNBACH, I., KUBJATKO, T., KOLLA, E., ONDRUŠ, J., SARIC, Z., (2020). Methodology designed to evaluate accidents at intersec_tion crossings with respect to forensic purposes and transport sustainability. Sustainability, vol. 12, no. 5, pp. 72-84. DOI: 10.3390/su12051972.

FREJ, D. P., LUDWINEK, K., (2020). Analysis of road accidents in 2002-2019 on the example of Poland. The Archives of Automotive Engineering - Archiwum Motoryzacji, vol. 89, no. 3, pp. 5-18. DOI: 10.14669/AM.VOL89.ART1.

KOPENCOVA, D., (2020). Secondary education with security focus. 14th International Technology, Education and Technology and Development Conference. INTED2020 Proceedings, pp. 2477-2481, DOI: 10.21125/int_ed.2020.0755, https://library.iated.org/view/KOPENCOVA2020CZE.

KOPENCOVA, D., RAK, R., (2020). Issues of Vehicle Digital Forensics. 2020 XII International Science-Technical Conference AUTOMOTIVE SAFETY, pp. 1-6. DOI: 10.1109/AUTOMOTIVESAFETY47494.2020.9293516, ieee.org/document/9293516

KUBJATKO, T., GÖRTZ, M., MACUROVA, L., BALLAY, M., (2018). Synergy of forensic and security engineering in relation to the model of deformation energies on vehicles after traffic accidents. Transport Means Procedings of the International Conference, pp. 1342-1348.

POLIAK, M., TOMICOVÁ, J., JAŚKIEWICZ, M., (2020). Identification the Risks Associated With the Neutralization of the CMR Consignment Note. Transportation Research Procedia, vol. 44, pp. 23-29. DOI: /10.1016/j.trpro.2020.02.004.

RAK, R., (2020). Analysis of VIN Errors in Information Systems, Causes, Consequences and Solutions. Proceedings of 1st International Conference on Structural Damage Modelling and Assessment. Lecture Notes in Civil Engineering, Vol. 110, pp. 271-280. DOI: 10.1007/978-981-15-9121-1_21.

RAK, R., ZRUBAK, R., (2012). Project eCALL - Car in Emergency Situation. 7th Scientific International Conference on Crisis Management: Environmental Protection of Population. Proceeding paper, pp. 251-258. https://www.we_bofscience.com/wos/woscc/full-record/WOS:000394562600028. [accessed on 2021-01-10].

STANCZYK, T. L., JURECKI, R.S., JASKIEWICZ, M.J., FREJ, D., LAGOWSKI, P., ZUSKA, A., et al., (2020). Braking performance tests for different types of vehicles. 12th International ScienceTechnical Conference Automotive Safety, Automotive Safety 2020. DOI: 10.1109/AUTOMOTIVESAFETY47494.2020.9293532.

ZBOUKERCHE, A., SIDDIQUI, A. J, MAMMERI, A., (2017). Automated Vehicle Detection and Classification: Models, Methods, and Techniques. ACM Computing Surveys, vol. 50, no. 5. DOI: $10.1145 / 3107614$. 
DOI: 10.36682/SSS_2021_6

\author{
Mgr. Ivana Kabarová \\ Odbor zdravotnictví Department of Health \\ Krajský úřad-Moravskoslezský kraj Regional Authority-Moravian-Silesia Region \\ Katedra bezpečnosti práce a procesů Department of Occupational Safety and Processing \\ Fakulta bezpečnostního inženýrství Faculty of Security Engineering \\ Vysoká škola báňská - Technická univerzita Ostrava VSB - Technical University of Ostrava \\ $\triangle$ 28. ř́jna 117, PSČ 702 18, Moravská Ostrava, Ostrava, the Czech Republic \\ $\triangle$ Lumírova 630/13, PSČ 700 302, Výškovice, Ostrava, the Czech Republic \\ E-mail: ivana.kabarova@msk.cz \\ E-mail: ivana.kabarova@vsb.cz
}

prof. RNDr. Pavel Danihelka, CSc.

\author{
Katedra bezpečnosti práce a procesů Department of Occupational Safety and Processing \\ Fakulta bezpečnostniho inženýrství Faculty of Security Engineering \\ Vysoká škola báňská - Technická univerzita Ostrava VSB - Technical University of Ostrava \\ $\triangle$ Lumírova 630/13, PSČ 700 302, Výškovice, Ostrava, the Czech Republic \\ E-mail: pavel.danihelka@vsb.cz.
}

\begin{abstract}
Annotation
Capacity and functionality are one of inpatient medical facilities. However, they can fail or even collapse in some situations for many reasons, such as external disasters, internal dysfunctions and also because of the surrounding infrastructure malfunction or an overloaded health system. This vulnerability, often underestimated in the past, had shown to be critical during the COVID-19 epidemic but it can still manifest itself in a number of other crisis situations. The domino effect is also significant phenomenon, i.e. the spread of impacts on other facilities. Inpatient-oriented medical facilities thus have a function as infrastructure at the level of a large territorial unit and the experience with COVID-19 provides the knowledge that it is in fact a critical infrastructure. These conclusions are illustrated in the presentations by case-studies in the Moravian-Silesian Region.
\end{abstract}

Key words: risk management, inpatient medical facility, domino effect, threat

\title{
Introduction
}

Critical infrastructures are systems with complex links that directly interfere with disaster risk reduction and prevent not only life loss and damage to health but also provide the background to economic, physical, social, cultural and environmental society needs. But each system can, and even must, react with other systems in different ways, including by reacting to the possibility of cascading so-called ,failure chain" or ,domino effect“ (UNDRR, 2017).

Many states, cities, or municipalities can identify their critical systems, but only a few can understand how interconnected they are. Indeed, in an extreme case, it may also be ,infrastructure of infrastructures". Achieving critical infrastructure resilience requires efforts to identify and evaluate these links, but the required data may be in different ownership than, for example, the relevant authorities, i.e. another public authority or even the private sector. Critical infrastructure resilience must be treated as a process in which resilience levels change and are restored or degraded over time, if only because, for example, climate or societal changes occur. This means that "resilience" must be 
understood in terms of „resilience“ as an adaptive process and not in the often-used „resistance“ as a passive property. Therefore, all risks need to be regularly assessed and comprehensively assessed. Many developed nations thus include in critical infrastructure all risk areas that may threaten their populations, including health care (e.g. the US). In the Czech Republic the health sector belongs under the so-called crisis legislation, especially in Laws No. 240/2000 Coll., No. 241/2000 Coll., No. 239/2000 Coll., and on related regulations, implementing decrees and government regulations. The operator must then take a number of measures to ensure that the operation of such equipment is not interrupted, even in emergencies or emergencies. However, according to Government Regulation No. 432/2010 Coll., setting criteria for the identification of a critical infrastructure element, although the health service is not included there. Health is regulated only by the fact that the cross-cutting criteria are, among other things: „,impact on the public with the limit of a large reduction in the provision of necessary services or other serious interference in everyday life affecting more than 125000 people ". However, most regional hospitals, let alone even smaller health establishments, do not meet this criterion. Thus, formally it follows that an in-patient medical facility, e.g. with a catchment rate for perhaps 50,000 inhabitants, is not important. But according to the sectoral criteria of the regulation (point IV - health), when it is considered an element of critical infrastructure , medical establishment whose total number of acute beds is at least 2500." This raises questions: how many such inpatient health facilities do there exist in the Czech Republic? How are they interconnected and how are they connected to smaller devices? However, our health service has no officially critical infrastructure element and hospitals and/or inpatient health facilities do not then have to process Crisis Preparedness Plans which is in dramatic contrast to the experience of the COVID-19 crisis (Štěpán, 2018).

\section{Historical medical failures}

We present the great Lisbon earthquake from 1755 as the imaginary dividing line for determining the first modern disaster. This event was also the trigger for some of the first scientific research into the causes of earthquakes and whether these disasters can be predicted and thereby ensure greater population safety (Etkin, 2015). But historical records describe events that were associated with diseases or disasters and that ended in the death of large population numbers. Most often referred to as epidemics and often associated with religious overtones, they were the ,plague“ or „black death“ as a punishment of God.

One of the earliest descriptions of the epidemic, which is believed to be a real plague, was in 558 AD. These were so-called the Justinian Plague. Millions of people died in this epidemic, with 5-10,000 dying every day in the capital city of Constantinople alone, and the total collapse of the health service of that time. In the Middle Ages, the plague hit all Europe, and also the Czechs in three waves. The first documented wave hit Europe and also the Czechs in 1357-1363. The consequences were catastrophic. An estimated one-third to one-half of Europe's population has died. The second, stronger wave in Europe, which also affected the Czechs was in 1380-1382. Its effects were no longer as drastic for us but preserved records suggest tens of thousands of casualties. More plagues came in 1711-1715 and struck most of Europe. Around 200,000 people died with this disease in the Czech Republic alone. All these events were accompanied by the health service ceasing to perform its normal functions at the time level. After 1828, plague epidemics were no longer present in Europe, but other insidious diseases began to appear, such as cholera, which reached Europe by sea from India (Svoboda, 1995). In all the major plagues, the failure of health services has also proved to be part of the crisis. Modern pandemics in the 20th and 21st centuries include, without doubt, Spanish flu (1918-1920). Hospitals were hopelessly overcrowded during the epidemic and faced shortages of doctors and nursing staff. Only as many patients were admitted in a day as there were deaths. Other disciplines were closing, e.g. otorhinolaryngology, dentistry and specialists had to switch to general practice. People often died at home without medical care or assistance, which was also lacking due to wartime events. There were major shortages in medicines and raw materials necessary for the manufacture of medicines, mainly quinine at the time, and such as sweeteners, alcohol and preparations, or even lacking the necessary production aids, e.g. medical glass. Here is a parallel with the lack of oxygen at COVID-19 in the world. The lack of quinine was also due to the fight against malaria (Splenia). The unbearable situation occurred in the congestion of cemeteries, there were few gravediggers, carpenters, small morgues were overcrowded and some of the deceased remained outside. Due to the lack of coffins, the dead were buried in communal, so-called mass graves (Salfellner, 2017). Other pandemics in the world included 
e.g., Asian flu (1957-1958), Hong Kong influenza (1968-1969), swine flu pandemic caused by H1N1 influenza virus (2009-2010) and newly COVID-19 (SARS-CoV-2).

Disasters affecting the health service are innumerable, that is why we present only the small sample of selected disasters since the beginning of the 21 st century that have interfered with the activities provided by health services. This includes: floods that forced the evacuation of patients and led to the closure of critical services at Burkina Faso's main hospital in the capital Ouagadougou (9/2009). National and local health systems providing health services to millions of people have been affected by the damage and destruction of thousands of medical facilities in Gujarat, India (2001), the northern Indonesian province of Aceh (2004), Pakistan (2005) and Myanmar (2008) (DOH, 2013). The earthquake that struck China (2008) damaged or destroyed more than 11,000 medical facilities. In Haiti 2010, the earthquake left 230,000 people dead and cholera spread, killing 10,000 people and spreading then to the neighbouring Dominican Republic. In August 2021, another large earthquake occurred in Haiti, the local doctor reported: „We didn't have time to count the dead, we were just treating the wounded, of which there were many....There are cracks on the walls of the emergency department of the hospital. So we worked in the yard of the hospital for fear of collapse." (Kedroň, 2021). Attacking health workers and medical facilities, which tend to be targeted by attackers or terrorists. During the three-week emergency in the Gaza Strip in 2008-2009, 16 medical workers were killed and 25 injured in the line of duty, 15 hospitals, 41 primary health centres and 29 ambulances were damaged (Štětina, 2014). Hurricanes, typhoons: a typical example is Hurricane Katrina (2005), which damaged protective dams and completely flooded the town with water from the ocean and nearby Lake Pontchartrain. The city of New Orleans subsequently flooded. Before the impending catastrophe Failed to evacuate the city in time, there was a collapse of the infrastructure, including health care, and civil unrest. The lights in the hospitals were without spare resources, the use of toilets was forbidden, water had to be saved and every patient was equipped with a flashlight. Patients were given a zero dry diet and bottled water from reserves according to UNDAC (The United Nations Disaster Assessment and Coordination) standards (Baldwin, Robinson, Barlow, Fargason, 2006). About 432 medical facilities were damaged by Typhoon Haiyan (Yolanda) in the Philippines in 2013, including 296 Barangay Medical Stations, 97 rural health units, 38 hospitals in the Eastern Visayas region, including the office of the Ministry of Health (DOH of the Philippines, 2013). Tropical Storm (Allison, 2001) devastated southeast Texas. Most of the damage was in Downtown, where water flooded hospitals and other buildings. There were floods along Allison's passage, and the resulting electrical failure forced the evacuation of University Hospital Houston. The hospital had 450 adult's beds and 150 children's beds. 169 patients were discharged and 406 gradually evacuated to 29 hospitals (Cocanour, Allen, 2002). Nowadays there is a growing number of cyberattacks, including in the Czech Republic. It can therefore be summarised that in-patient healthcare facilities are generally vulnerable to a variety of disasters and events, and their possible dysfunction exacerbates the crisis.

\section{The importance of inpatient health facilities for the population and its protection}

The precise definition of health establishments and their function is formulated by the legislation in force in the Czech Republic, Act No. 372/2011 Coll., on health services and the conditions for their provision (Health Services Act), as amended, which clearly states that ,health facilities are spaces intended for the provision of health services". Health services can be divided according to the form and type of healthcare provided in health establishments. Bedside care is such healthcare that cannot be provided on an outpatient basis and patient's hospitalisation is necessary for its provision and is provided in the framework of continuous operation.

The buildings of medical facilities that are specific are also very important. These are often pooled outpatient facilities (policlinics), institutional care facilities (hospitals that form bed units with investigation and treatment units. And other necessary spaces for the functioning of the medical facility (warehouses, boiler rooms, garages, farm buildings etc). A large number of different ages people, who may be in critical conditions, are concentrated in health buildings, after severe surgery, not including immobile patients, the mentally ill, those under the influence of pharmacological treatment, parents and new-borns or neonatal children, at any hour of the day or night. Persons moving in these areas are not only patients, but also others who are not health professionals, but contribute to the running of the 
organization, e.g. non-medical staff of the facility, construction companies employees, maintenance, shops and also accompanying the sick, visits etc.

The function and importance of health facilities to the population is primarily to provide health care, which consists of a set of activities such as: prevention, detection and elimination of disease, maintenance, restoration or improvement of health and function, maintenance and prolongation of life and suffering, provision of palliative care, assistance in reproduction and delivery, provision of preventive, diagnostic, therapeutic, therapeutic rehabilitation, nursing care. Its other activities include: educational, scientific-research, economic, operational, technical, investment, administrative and pharmacy care provision.

Losses of function such as critical vulnerability of inpatient health facilities include threats that are external e.g.: floods, prolonged drought, extreme temperatures (heat waves), extreme wind, epidemics (COVID-19, influenza etc.) and disruption of large-scale electricity supply (blackout) or internal threats such as: fires, lack of qualified staff, inadequate logistical security (e.g., oxygen, pharmaceuticals, water, food, materials, etc). Other potential risks to the inpatient medical facility also include an attack by a hostile person, both physical and virtual (placement of a booby trap explosive device, violent crime with a weapon, where it may be directly a terrorist attack or a mentally ill person, or an attack on the hospital information system - a cyber-attack).

Inpatient medical facility not fulfilling its functions $\Rightarrow$ domino effect and its consequence in health care $=$ collapse of the system (depleted medical staff, until its devastation, filled capacity of beds, logistical collapse, economic impact in health care etc.

\section{Examples of vulnerability during the COVID-19 epidemic, including the domino effect}

Based on mapped data, it can be read that LZZ can be compromised by both external and internal risks, often leading not only to the failure of an individual hospital, but to the collapse of the entire health system, which can lead to fatal consequences, and so-called: ,a domino effect which leads to the possibility of increasing the likelihood of the occurrence or consequences of a major accident due to the proximity of devices, objects or groups of objects and the location of dangerous substances", as defined precisely by Law No. 224/2015 Coll., Major Accident Prevention Act (Section 2). In the current coronavirus epidemic, there is also a domino effect in health care. The result is then a collapse of the system and consequent problems such as: shortage of medical staff, lack of beds not only in intensive care units which are not sufficient in their capacity, but also dissecting rooms and morgues have problems. Doctors may find it difficult to choose which patients to provide artificial pulmonary ventilation or a bed, oxygen or medication. Other downstream health needs that are necessary to maintain activity and functionality are the supply of pharmaceuticals, food, medical supplies, especially sterile, laundry, waste collection and also energy supply (water, electricity, heat etc.) that will go into logistical meltdown.

By overloading incinerators, infectious waste from health care is increasing due to increased use of protective equipment during the epidemic, which will even rise by tens of tons. Infectious materials, surgical or bandage materials used, sharp objects, drug residues or protective equipment etc., which must be largely burned, are considered hazardous waste. At University Hospital Ostrava, for example, the amount of waste increased by seven tonnes. The collection company had to transport infectious waste even three times a day, in normal operation the waste is collected once or twice a day (Vlčková, 2021).

COVID-19 as a demonstration of the vulnerability of inpatient health facilities and its infrastructure

As a demonstration of the vulnerability of inpatient health facilities, I illustrate data from the application of the COVID-19 dashboard portal, created by the Moravian-Silesia Region, when up to 1013 standard beds were occupied by covid positive patients (Picture No. 1 - Chart 1), 189 intensive care beds and 120 machines for artificial lung ventilation (Picture - Chart 2) were in operation. 
Picture 1: Chart 1 Number of hospitalised patients and bed roundness COVID-19 standard in the Moravian-Silesia Region (period 29.11.2020 - 13.06.2021)

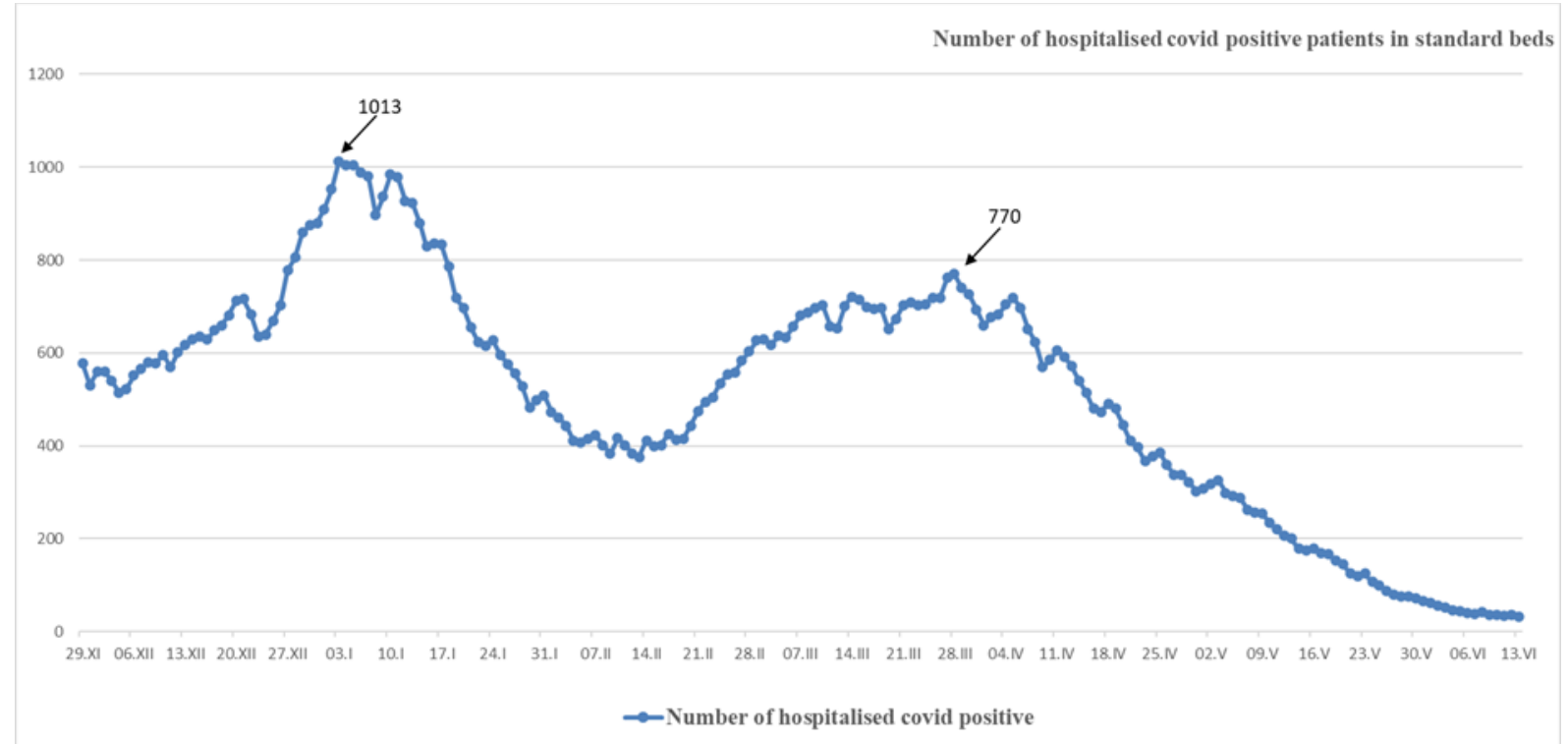

Source: the Moravian-Silesia Region, Department of Health, 2020

There are 22 in-patient health facilities providing acute in-patient care in the Moravian-Silesia Region, the total capacity of beds by the date 31.05.2021 was 6773 (updated by the Moravian-Silesia Health Department). According to the Czech Statistical Office, till 31.12.2020, there were 1192834 inhabitants in five districts in the territory of the Moravian-Silesia Region (ČSÚ, 2020). 
Picture 2: Chart 2 Number of patients hospitalised and bed obscurity - intensive care and artificial lung ventilation during COVID-19 in the Moravian-Silesia Region (period 29.11.2020-13.06.2021)

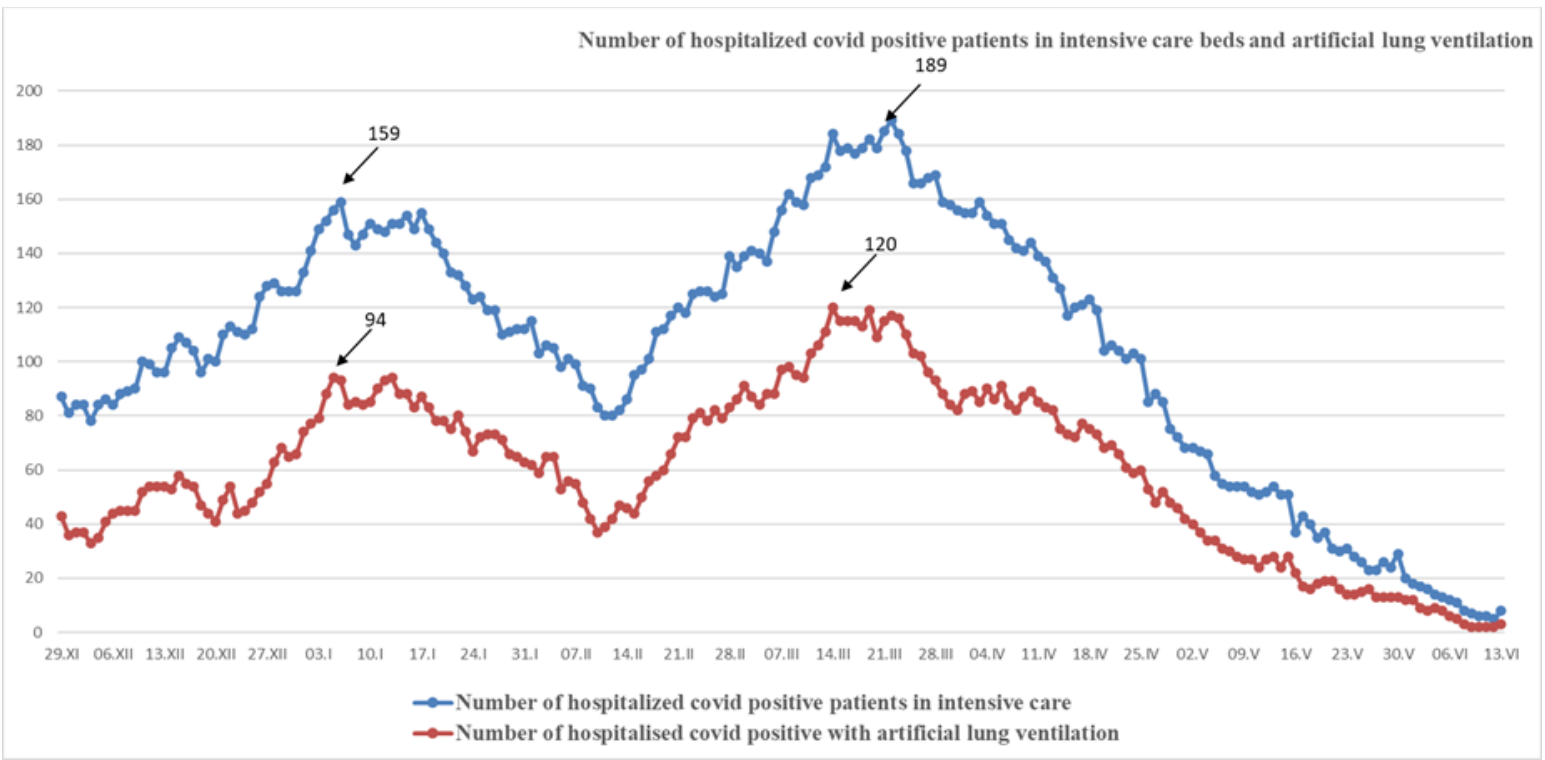

Source: the Moravian-Silesia Region, Department of Health, 2020

Another vulnerable link during the epidemic was the absence of medical staff in hospital beds due to COVID-19 (disease, quarantine, infirmary). Up to 149 doctors (Picture 3 - Chart 3) and 886 non-medical staff (Picture 4 - Chart 4) were absent in the Moravian-Silesia Region. In particular, there was also a monitored group of non-medical staff also involved in the functioning of the organisation.

Picture 3: Chart 3 Absence of medical staff due to COVID-19 - medical staff in the Moravian-Silesia Region in inpatient health facilities (period 29.11.2020-13.06.2021)

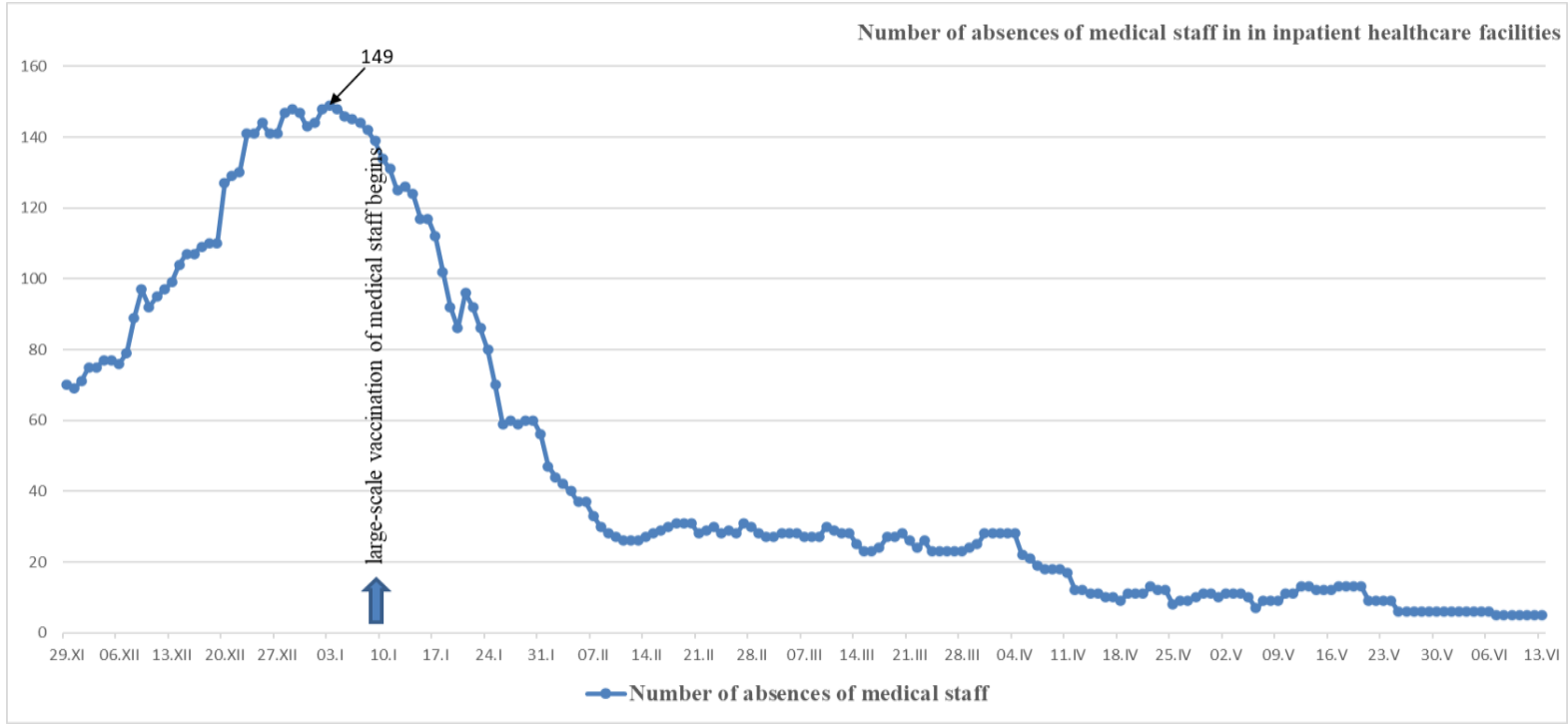

Source: the Moravian-Silesia Region, Department of Health, 2020 
Picture 4: Chart 4 Absence of medical staff due to COVID-19 - non-medical medical staff in the Moravian-Silesia Region in inpatient health facilities (period 29.11.2020-13.06.2021)

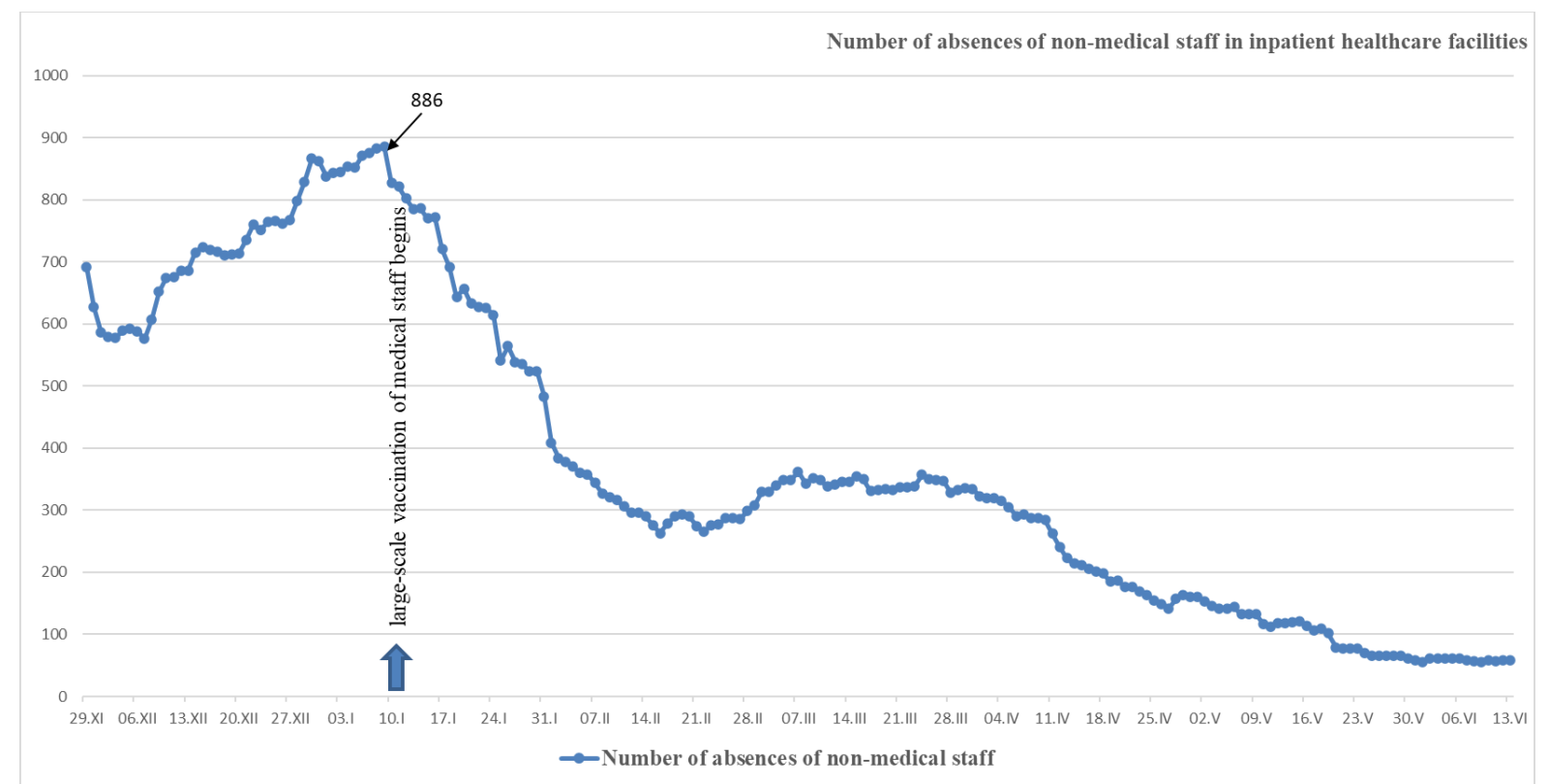

Source: the Moravian-Silesia Region, Department of Health, 2020

In-patient medical facilities there were no planned operational services, specialised departments were closed, staff were concentrated on acute beds or earmarked so-called "Covid departments". Only emergency care was provided by government order. Hospital visits were banned or individual visit exceptions (e.g., palliative care) were provided. In the first week of January 2021, the vaccination of medical staff began to increase and the absence from inpatient health facilities decreased sharply, as shown in both graphs 3 and 4. Despite vaccination of medical staff, non-medical staff remain absent in greater numbers during the spring months of 2021, due to the still persistent lockdown, closure of schools, nurseries and use of the infirmary, as non-medical staff are mainly composed of women.

Dashboard further processed data entered by medical devices from the portal application and drew attention to congestion. If the tile was tinted yellow, the capacity was filled to 80 per cent. If the tile turned red, capacity was exhausted. White paint indicated that capacities were within the norm.

The created application of the dashboard portal also presented other sections important for maintaining the activity of the network of inpatient health facilities in the Moravian Region, namely the already presented overview of bed aberrations of covid positive patients, including prospects, an overview of missing staff, a supply of protective work equipment and medical supplies, the number of COVID-19 tests performed and the workload of laboratories.

\section{Need for a systematic solution, including the inclusion of wider society = resilience}

For many decades, international organisations have sought to reduce the risks of disasters, for example by holding regular conferences. In 2015, the Third World Conference took place in Sendai, Japan, establishing the Sendai Disaster Risk Reduction Framework 2015-2030, which it calls for in its Priority 3 concept: invest in disaster risk reduction leading to resilience, aiming at investing in disaster prevention and reduction. That point Sendai Framework directly seeks to reduce disaster risks for inpatient healthcare facilities, which means improving the resilience of national healthcare systems, including integrating disaster risk management into primary, secondary and tertiary healthcare, especially at the local level; develop the capabilities of health professionals to understand disaster risks and implement disaster risk reduction approaches in their work, support and strengthen resources for disaster medicine training, while supporting health in communities on disaster risk reduction approaches in health programs= RESILIENCE (Sendai, 2015). In the Czech Republic, the Sendai Framework for Disaster Risk Reduction is implemented by the Ministry of the Environment (MŽP, 2020) and is also 
dedicated to environmental safety. The basic document consists of: Concept of environmental safety 2021-2030 with a view to 2050 .

Helping a society in crisis - concrete examples

The example of the possibility of helping the company is the RESIMAS Security Research Project. It includes the involvement of Local Action Groups and the creation of working teams to create a local disaster risk reduction platform. Verification of the crisis planning effectiveness by means of tactical exercises in regional hospitals of the Moravian Region (already conducted exercises in 2015-2019). Conducting analysis of the emergencies impacts on the population in the Moravian-Silesian Region and incorporating it into the Crash Plan. Further support large-scale process electronisation and projects (e.g., training of health professionals, ambulances) as the part of the current challenges in the MoravianSilesian Region. IT systems, construction of emergency revenue etc. Continue also to make further use of collaborations with scientists and doctors (e.g., Initiative Snow) or components of the Integrated Rescue System, the army of the Czech Republic and emergency plans in the Moravian-Silesian Region.

\section{Conclusion}

Bedside health facilities are the integral protection part of residents and critical infrastructure and should be understood as such. Governments wishing to implement the Sendai framework must keep many critical infrastructure systems operational, including health, which is essential for the country's population. Monitoring the health system is literally crucial for managing emergencies and evaluating risk areas. Equally important are human resources which form a strong link in the health service and their continuous education and ensuring their safety and quality which is essential for their work.

\section{Literature}

BALDWIN, S., ROBINSON, A., BARLOW, P., FARGASON, C., A. (2006). Interstate Transfer of Pediatric Patients During Hurricane Katrina. Pediatrics Volume 117, Number 5. [online]. May 2006, 416-420 pgs. [cit. 2006-05-29]. DOI: 10.1542/peds.2006-0099O. Available at WWW: https://pediatrics. aappublications. org/content /117/Supplement_4/S416.

COCANOUR, Ch., S.; ALLEN, S., et al.: (2002). Lessons learned from the evacuation of an urban teaching hospital. Arch Surg 2002; 137:1141-1145. DOI: 10.1001/archsurg.137.10.1141.

DEHNER, J., (2020). Krajská správa ČSÚ. Obyvatelstvo v Moravskoslezském kraji v 1. čtvrtletí 2020. [online]. Ostrava: Czech Statistical Office, [cit. 2021-10-04]. Available at WWW: https://www.czso.cz/csu/xt/obyvatelstvo-v-moravskoslezskem-kraji-v-1-ctvrtleti-2020.

ETKIN, D., (2015). Disaster Theory: Edition An Interdisciplinary Approach to Concepts and Causes. Publisher: Butterworth-Heinemann; Illustrated edition. 368 pgs. ISBN: 9780128002278.

KEDROŇ, R., (2021) Haiti drží třídenní státní smutek za oběti zemětřesení. Úřady evidují již téměř 2000 zemřelých. 2021. [online]. iROZHLAS. [cit. 2021-08-17]. Available at WWW: https://www.irozhlas.cz/zpravy-svet/haiti-zemetreseni-obeti-statni-smutek_2108172319_onz.

MINISTERSTVO ŽIVOTNÍHO PROSTŘEDÍ ČESKÉ REPUBLIKY. (2020). Koncepce environmentální bezpečnosti 2021-2030 s výhledem do roku 2050. [online]. Prague: Ministry of the Environment of the Czech Republic. 2020. Available at WWW: https://www.mzp.cz/cz/environmentalni_bezpecnost

SALFELLNER, H., (2017). Pandemie španělské chřipky 1918/19 se zvláštním zřetelem na České země a středoevropské poméry. [Dissertation]. [online]. Prague: Charles University in Prague 1st Medical Faculty. Available at WWW: https://is.cuni.cz/webapps/zzp/detail/147785/.

SENDAI, (2015). 3. Světová konference o snižování nebezpečí katastrof. Rámec pro snižování rizika katastrof Sendai 2015-2030. (2015). Sendai, Miyagi, Japonsko. 2015. [online]. Available at WWW:https://www.mzp.cz/C1257458002F0DC7/cz/environmentalni_bezpecnost/\$FILE/OKRramec_ snizovani_rizika_katastrof_sendai-20160606.pdf. 
SVOBODA, J., (1995). Historie morových pandemií. [online]. Magazine: Vesmír 74, 496, 1995/9 [cit. 1995-09-05]. Available at WWW: https://vesmir.cz/cz/casopis/archiv-casopisu/1995/cislo-9/historiemorovych-epidemii. html.

ŠTĚPÁN, M., (2018). Připravenost zdravotnických zařizení na mimořádné události. Nemocnice jako prvek kritické infrastruktury. 2018. [online]. Publish: České vysoké učení technické v Praze. Process: Fakulta biomedicínského inženýrství. [cit. 2021-20-08]. 27 s. ISBN 978-80-01-06510-5. Available at WWW: https://www.fbmi.cvut.cz/sites/default/files/2018-11-fotogalerie/Sbornik $\% 20 \% \quad 20 \mathrm{P} \%$ C3\%B8ipravenost \%20ZZ\%20na\%20MU.pdf.

ŠTĚTINA, J., a kol. (2014). Zdravotnictví a integrovaný záchranný systém při hromadných neštěstích a katastrofách. Prague: Grada Publishing, a.s., 584 pgs. ISBN 978-80-247-4578-7.

THE DEPARTMENT OF HEALTH. (2013). DOH goes full throttle for typhoon Yolanda victims. [online]. Ministry of Health of the Philippines. 2013. [cit. 2013-11-29]. Available at WWW: https://www.officialgazette.gov.ph/2013/11/29/doh-goes-full-throttle-for-typhoon-yolanda -victims/.

THE MORAVIAN-SILESIA REGION. (2020). Dashboard COVID-19. [online]. Ostrava: Department of Health. Available at WWW: portal.msk.cz/ aplikace/koronavirus-dashboard/

UNITED NATIONS OFFICE FOR DISASTER RISK REDUCTION. (2017). Critical Infrastructure and Disaster Resilience: Issue Brief by Private Sector (ARISE). 2017, 15.11.2017. 6 pgs. [online]. [cit. 2021-19-08]. Available at WWW: https://reliefweb.int/sites/ reliefweb .int/files/resource s/55922_55922critical infra structureanddisas.pdf.

VLČKOVÁ, T., (2021). Koronavirus vrší tuny odpadu navíc. Nemocnice jeho spalování mohou odkládat. Idnes.cz. [online]. [cit. 2021-01-14]. Available at WWW: https://www.idnes.cz/zpravy/ domaci/infekcni-odpad-pandemie-koronavirus-covid-19-spalovny-nemocnice-zdravotnicka zarizeni .A 201216 _145917_domaci_vlc 


\title{
Fire Prevention of Municipal Waste Landfills
}

DOI: $10.36682 / S S S \_2021 \_7$

PhDr. Stepan Kavan, Ph.D.

\author{
Hasičský záchranný sbor Jihočeského kraje Fire Rescue Service of South Bohemia \\ České Budějovice České Budějovice \\ $\triangle$ Pražská 52b, 37004 České Budějovice, Czech Republic \\ E-mail: stepan.kavan@email.cz \\ Ústav radiologie, toxikologie a ochrany obyvatelstva Institute of Radiology, Toxicology ad Civil Protection \\ Zdravotně sociálni fakulta Faculty of Health and Social Science \\ Jihočeská univerzita v Českých Budějovicich University of South Bohemia in České Budějovice \\ $\triangle J$. Boreckého1167/27, 370 11, České Budějovice, Czech Republic
}

\begin{abstract}
Annotation
Landfill fires with their character rank in most cases among large-scale fires, when the stored material burns on the surface and in most cases also subsurface burning. The second case is very complicated in terms of firefighting tactics. The article focuses on important rules for the operation of mixed municipal waste storage facilities, mainly from the point of view of fire and fire prevention. The problem is solved both in outdoor warehouses, where the main purpose is to store a large amount of waste in one place, where the waste will be stored for many decades and smolder under a layer of soil without further apparent processing, and in indoor warehouses, which is temporary storage. . The operation of the landfill is divided into three basic parts. The first part of the landfill operation is the operation of waste disposal facilities by depositing them at or below ground level. The second part of the landfill operation is the operation of facilities for the possible use of waste during the closure and reclamation of the landfill. The third and final part of the landfill operation is the operation of a facility not intended for waste management in order to ensure the subsequent care of the landfill after its closure. The complexity and complexity of firefighting procedures is presented on a specific example of a landfill fire.
\end{abstract}

\section{Key words}

Fire prevention, municipal waste, fire, landfill

\section{Introduction}

The article focuses on important rules for the operation of mixed municipal waste storage facilities, mainly from the point of view of fire and fire prevention. The problem is solved both in outdoor warehouses, where the main purpose is to store a large amount of waste in one place, where the waste will be stored for many decades and smolder under a layer of soil without further apparent processing, and in indoor warehouses, which is temporary storage.

In the case of outdoor mixed municipal waste storage facilities, from the point of view of fire safety, attention is paid to the preventive activities of the employees of the mixed municipal waste storage facility, especially with regard to the fire of the mixed municipal waste storage facility. it did not accumulate unnecessarily and thus a large part of the stored mixed waste did not lie in water (Pokorný et al., 2015; Brumar et al., 2018). This water could then pollute surface or groundwater sources, which would significantly damage the environment.

In the case of indoor storage of mixed municipal waste, fire safety deals with the temporary storage of mixed waste, as the indoor storage of municipal waste is one of the parts of the incineration process of mixed waste. In this case, fire prevention (Dušek, 2015; Becker, 2000) should guarantee that an uncontrolled fire does not occur in this warehouse and does not damage other parts that are connected 
to the warehouse. Furthermore, fire prevention guards the areas around the combustion boiler so that the fire from the combustion chamber does not spread uncontrollably further along the transporters transporting municipal waste to the boiler, and so that this fire does not cause property damage to other equipment or other adjacent buildings.

\section{Fire Protection and Fire Prevention}

A fire is "an undesirable burning operation in which persons or animals are killed or injured, damage to property or the environment, and an undesirable burning operation in which persons, animals, property, or the environment were immediately endangered." (Kvarčák, 2005).

Combustion is a chemical-physical process that always occurs under certain conditions. There are three basic combustion conditions, the first condition is a flammable substance, ie a material that can burn, the second condition is an oxidizing agent or oxygen, which allows a flammable substance to ignite and burn, and the third condition is an ignition source that allows us to ignite a flammable substance. Burning in enclosed spaces is completely different than in open areas. There is a rapid smoking of the enclosed space, a change in oxygen concentrations to other gases, and thus changes the combustion conditions. Holes, their distribution and number, and their opening or closing for the exchange of indoor air and pressures from the surroundings are important for combustion in enclosed spaces (Kvarčák, 2005; Kovářové et al., 2014).

Fire safety of buildings is "the ability of buildings to prevent loss of life and health and loss of property in the event of a fire; it is achieved by suitable urban integration with the measures of the building, its dispositional, constructional and material solutions, or safety devices and measures.

Fire safety of buildings is solved for all types of buildings, and according to the characteristics of their use individually (Kročová et al., 2019). Fire regulations contain requirements for individual groups for the solution of fire safety equipment. Examples of individual groups of buildings are, for example, school buildings, production facilities, historic buildings, office buildings, various warehouses, chemical plants, sports halls, residential buildings and more. Functional fire safety devices are installed in some buildings (Mytton, 1995).

Fire technical properties of building materials are the properties of the materials from which building materials are formed. When the exact properties of the materials used are known, the fire protection of the building can be precisely determined, and the choice of the materials used will also have a significant impact on the fire safety of the individual building structures. Important properties of the used structures, which affect the final quality of the construction, must be verified according to special regulations. The fire technical properties of building structures have the main property, namely the fire resistance of individual structures, which means how long the building structures will be able to withstand the effects of an emergency, in this case a fire. Building structures are always used according to the operation in individual buildings, when the specific building structure used must withstand, for a certain period of time, one or more limit states which may arise in the event of a fire. In the Czech Republic, the resistance time of a building structure ranges from 15 to 180 minutes (Šenovský, 2004).

Fire resistance of building structures is the ability of building structures to resist the effects of fire and retain their original properties, such as load capacity, integrity, insulation, and others (CS 73 7310).

\section{Waste Management}

According to the Waste Act, basic terms can be defined as (Act No. 185/2001 Coll.):

- Waste is any movable thing that a person disposes of or has the intention or obligation to dispose of.

- Municipal waste is all waste generated on the territory of the municipality during the activities of natural persons, and which is listed as municipal waste in the Waste Catalog.

- Waste similar to municipal waste is all waste generated on the territory of the municipality during the activities of legal entities or natural persons authorized to do business and which is listed as municipal waste in the Waste Catalog. 
- Waste management is an activity aimed at preventing the generation of waste, at the management of the waste generated, and at the care of the place where waste is permanently collected and these activities are controlled.

- Waste management is the trading of waste, the collection, collection, purchase, transport, transportation, storage, treatment, recovery and disposal of waste.

- Waste storage is the temporary concentration of waste in a dedicated facility for a maximum period of 3 years before its use or 1 year before its disposal.

- A landfill is a facility established in accordance with a special legal regulation and operated in three immediately consecutive phases of operation, including a facility operated by a waste producer for the purpose of disposing of his own waste and a facility intended for waste storage.

The operation of the landfill is divided into three basic parts. The first part of the landfill operation is the operation of waste disposal facilities by depositing them at or below ground level. The second part of the landfill operation is the operation of facilities for the possible use of waste during the closure and reclamation of the landfill. The third and last part of the landfill operation is the operation of a facility not intended for waste management in order to ensure the subsequent care of the landfill after its closure (Act No. 185/2001 Coll.).

\section{Fire Prevention in Outdoor Storage of Mixed Municipal Waste}

The fire prevention solution for this type of construction focuses on minimizing the risks and preventing the risks associated with the storage of municipal waste in cassettes.

The inclusion of operated activities according to the fire risk can be stated (Act No. 133/1985 Coll.):

- According to the degree of fire risk, the operated activities are divided into categories without increased fire risk.

- Activities not listed in paragraphs 2 and 3 shall be considered to be activities with an increased fire risk.

An open building is not divided into fire sections and is considered as one fire section. The whole landfill of this type will always consist of only one fire section, where these are parts that have not been closed and the reclamation process has not started.

The economic risk of a fire section is determined by the index of probability of fire occurrence and spread of fire with the index of probability of the extent of damage caused by fire. The values of the index depend on the type and nature of operation, fire safety measures, the size of the fire section, the number of floors in the building and the expected damage.

The probability index of the occurrence and spread of fire $\mathrm{P} 1$ is determined according to the equation:

$$
\mathrm{P} 1=\mathrm{p} 1 . \mathrm{c} \geq 0.11
$$

The probability index of the extent of damage caused by fire $\mathrm{P} 2$ is determined according to the equation:

$$
\mathrm{P} 2=\text { p2. S. k5. k6. k7. }
$$

Spacing distances

The distances are mainly used to prevent the transmission of fire from one building to another, or to prevent the transmission of fire from one fire section to another. The possibilities of transferring a fire from one fire section to another or from one building to another are by means of radiant heat, burning falling parts of the structure or flying burning particles. In this case, it is necessary to create a distance between buildings, which is defined by a fire hazardous area. In the case of free material storage, the distances are solved using ČSN 73 0804, paragraph 11.5.1. 
The distance is the perpendicular distance from the fire hazardous area, in this case the free warehouse of mixed municipal waste, to the boundary of the fire hazardous area. The smallest distance solved for free storage of flammable substances is $6.5 \mathrm{~m}$, unless other standards and laws stipulate a different distance. The required distance does not apply to buildings, unless they are free warehouses with a permanent or accidental fire load greater than $30 \mathrm{~kg} / \mathrm{m} 2$. Furthermore, no other free warehouses, open areas of other buildings or other fire compartments may be located in the fire hazardous area.

\section{Landfills and Incinerators in the Czech Republic}

In the Czech Republic, approximately 5,782,066 tons of mixed municipal waste was produced in 2018, which is the most municipal waste produced in the Czech Republic in the last seven years. This number has been steadily increasing in the last few years. Since 2011, the Ministry of the Environment has been publishing official yearbooks that have this information. In 2011, the inhabitants of the Czech Republic produced a total of 5,231,822 tons of mixed municipal waste. For the next two years in a row, ie 2012 and 2013, the production of municipal waste decreased. In total, it decreased to the value of 5,028,289 from 2013. Since 2014, the production of municipal waste in the Czech Republic has been growing every year (Statistical Yearbook, 2017).

There are 157 operated municipal municipal waste landfills in the Czech Republic. In the Capital City of Prague there is 1 operated landfill, in the South Bohemian Region there are 21 operated landfills, in the South Moravian Region there are 11 operated landfills, in the Karlovy Vary Region there are 4 operated landfills, in the Vysočina Region there are 9 operated landfills, in the Hradec Králové Region there are 7 operated landfills. There are 6 operated landfills in the Liberec Region, there are 17 operated landfills in the Moravian-Silesian Region, there are 13 operated landfills in the Olomouc Region, there are 12 operated landfills in the Pardubice Region, there are 13 currently operated landfills in the Plzen Region, there are 21 operated landfills in the Central Bohemian Region There are 13 operated landfills in the region, there are 9 operated landfills in the Zlín region.

Some municipal waste landfills are only small in size for the needs of municipalities, which transport waste from public bins, bins and similar small facilities to landfills. These landfills have annual volumes of only a few tens to hundreds of cubic meters of waste per year and operation at these landfills is limited to certain days and certain times, when mixed waste is collected here only from predetermined municipalities, mostly only from the municipality, which is the founder and operator. landfills and parts of municipalities that fall under the founding municipality. Mixed waste, which is collected from houses in cities and towns, then ends up in large landfills with volumes of several hundred thousand to millions of cubic meters per year.

As of 14 January 2020, there were a total of four mixed municipal waste incinerators in the Czech Republic. The energy from the combustion process, which is generated during the incineration of municipal waste, is also used, for example, to heat water into hot water pipelines. This water is then used for heating households in the suburbs, etc.

\section{Examples of Fire in Mixed Waste Landfills}

The fire at the municipal waste landfill in Černošín was reported at 15:34 as a waste fire on an area of $2000 \mathrm{~m} 2$. The reported emergency was then specified as a garbage can, container, waste fire. Immediately, the first level of fire alarm was announced by the Operations and Information Center. The units of the Černošín Voluntary Fire Brigade number of 14 firefighters and one piece of CAS mobile firefighting equipment, the Fire Brigade of the Pilsen Region of the Stríbro station consisting of 9 firefighters and three pieces of mobile firefighting equipment and the Volunteer Fire Brigade Unit came to the site of the emergency as the first fire protection unit. Silver consisting of 12 firefighters and two pieces of mobile fire equipment. These units arrived at the scene of the fire around 4 p.m.

An hour longer, after $5 \mathrm{pm}$, four more units arrived at the fire. Unit of the Fire and Rescue Service of the Pilsen Region Tachov station consisting of 12 firefighters and two pieces of mobile fire equipment, unit of the Fire and Rescue Service of the Pilsen Region with the station Pilsen - Košutka 1 firefighter and one piece of mobile fire equipment arrived went out in the composition of 4 firefighters and one 
piece of mobile firefighting equipment, but due to a breakdown on the vehicle did not reach the fire in full, three firefighters were transported to the scene by the Medical Rescue Service of the Pilsen Region, another unit of the volunteer fire brigade Kladruby arrived in the composition of 6 firefighters and one piece of mobile firefighting equipment.

After $6 \mathrm{pm}$, four more fire protection units arrived. A unit of the Svojšín volunteer fire brigade consisting of 5 firefighters and one piece of mobile fire equipment, a unit of the Tachov voluntary fire brigade consisting of 4 firefighters and one MPT unit, a unit of the Pilsen Region Fire and Rescue Service from the Regional Directorate arrived at the scene. a piece of mobile fire equipment, the Třemošná chemical laboratory and the Bor volunteer fire brigade unit consisting of 4 firefighters and one piece of mobile fire equipment.

On September 29, 2008, the Bor Volunteer Fire Brigade Unit, consisting of 4 firefighters and one piece of mobile firefighting equipment, arrived at the scene of the emergency again. From all the technology, it can be concluded that it was not a fire of the first degree fire alarm. After the arrival of the first units to the place of intervention, the commander of the intervention submitted a request for the announcement of II. fire alarm level to the Operations and Information Center. During the liquidation of the fire, the degree of fire alarm was increased to III. degree, when a mobile chemical laboratory from the village of Třemošná was also called. This chemical laboratory carried out measurements of air pollutant concentrations at the fire site and monitoring of the air condition during the next intervention.

The entire liquidation of the fire took three days, when on 28 September 2008 the emergency was reported to the Operations and Information Center and on 1 October 2008 the fire was handed over to the landfill owner for 24-hour supervision of the fire. A total of 15 mobile fire trucks, mostly CAS, and a total of 73 firefighters were involved in this emergency. Firefighters at the scene regularly took turns to extinguish the fire in order to avoid, as far as possible, excessive exhaustion and possible loss of human life. A total of 406,900 liters of water was used during the extinguishing.

Upon arrival of the Černošín Voluntary Fire Brigade Unit, work was carried out to prevent the further spread of fire in the area not affected by the fire. At the start of the firefighting work, the intervening firefighters used breathing techniques due to the thick smoke. Several attack $\mathrm{C}$ currents were created to prevent the spread of fire, and one CAS car was built, on which a rotating carriage jet was placed for better sprinkling of the fire. Next, the B hose was stretched, which was used to pump water from the overflow sump, which was again used to sprinkle the fire. During the first day, wheel loaders from the landfill operator were used to spread the fire and it was possible to achieve more effective extinguishing. At night, several units returned to their stations and wheel loaders were recalled. The Černošín volunteer fire brigade carried out monitoring and extinguishing outbreaks overnight. A water shuttle was also set up to the fire station, and a filling point was set up by the Stríbro Volunteer Fire Brigade Unit in the village of Černošín, where the fire tank was located. This tank was approximately $3 \mathrm{~km}$ away from the intervention.

On September 29, the Černošín volunteer fire brigade unit began further firefighting work, and wheel loaders were called again to open the landfill and to break off other fires. The fire site was handed over to the landfill operator on 1 October 2008 with mandatory 24-hour monitoring of the landfill. In the event of a fire, cooperation was conducted with the Police of the Czech Republic, the Municipal Council of the Municipality of Černošín, the Department of the Environment of the City of Stríbro, and the Mayor of the Municipality of Černošín.

During the fire, the pump on the CAS vehicle was damaged, the power plant, one piece of hose $\mathrm{C}$ and one piece of hose B were damaged, and the CAS unit of the Planá Volunteer Fire Brigade unit failed. The cause of the fire was evaluated as the self-ignition of flammable substances that were located in the storage area of the Černošín landfill. No material or other damage caused by the fire was found. 


\section{Conclusion}

Landfill fires with their character rank in most cases among large-scale fires, when the stored material burns on the surface and in most cases also subsurface burning. The second case is very complicated in terms of firefighting tactics.

In terms of determining the causes of fires, landfill fires are largely not investigated in accordance with the Instruction of the Director General of the Fire and Rescue Service of the Czech Republic and the Deputy Minister of the Interior No. 9/2003, which sets a uniform procedure for members of the Fire and Rescue Service the damage is zero and the protected values, due to the fact that it is no longer usable waste, are also zero.

If we look at this issue in terms of the time required for fire intervention, we find that the duration of the intervention is in many cases greater than the set limit of eight hours. The time complexity is followed by the complexity of deploying a large number of forces and resources. Although these costs are not reported as damages, in terms of fuel consumption, equipment renewal costs and labor costs for the activities of members of the Fire and Rescue Service of the Czech Republic and volunteer fire brigades, such interventions are very costly. Costs are not considered as damage incurred, but must be taken into account when evaluating interventions.

The impact of landfill fires on the environment is also very neglected and difficult to quantify. From the point of view of air protection and the impact of combustion products on the environment, these are often large-scale emergencies. It is necessary to choose the most appropriate procedure for assessing the impact on the state of the air and the quality of groundwater flowing out of the landfill and, in connection with the determined values, to take appropriate measures to reduce these effects on the environment and the surrounding population.

In relation to the surroundings of the landfill, in the vicinity of which there are smaller municipalities or cities, it is important to communicate with their representatives in the event of a fire and have a list of entities that can measure air pollutants and surface water contamination in a sufficiently short time. 2000). This measurement is important for subsequently informing citizens about the possible danger in connection with the fire and also for deciding on further activities in fire extinguishing. In good time, the population can be prepared to implement improvised measures to prevent the entry of gaseous pollutants into the building and measures can be prepared well in advance for the possible evacuation of the most endangered buildings.

\section{Literature}

BECKER, S., M., (2000). Environmental disaster education at the university level: an integrative approach In Safety Science, Elsevier BV, Vol. 35, Issues 1-3, 2000. DOI: 10.1016 / S0925-7535 (00) 00025-4.

BRUMAR, Jakub, BRUMAROVA, Lenka, POKORNY, Jiri. (2018). Airport integrated operational center. In: 2018 XIII International Scientific Conference - New Trends in Aviation Development (NTAD). Kosice: IEEE, 2018, pp. 25-29, ISBN 978-1-5386-7918-0, doi: 10.1109 / NTAD.2018.8551671.

ČSN 73 0810. (2016). Fire safety in buildings - Common provisions Prague: Office for Technical Standardization, Metrology and State Testing. 64 pp. ICS 13.220.50; 91.080.31.

DUŠEK, J., (2015). International Cooperation of Regional Authorities of the Czech Republic: History, Presence and Future. In Conference Proceedings "18th International Colloquium on Regional Sciences". Brno: Masaryk University - Faculty of Economics and Administration, pp. 300-305. DOI: 10.5817 / CZ.MUNI.P210-7861-2015-40. WOS: 000358536300040. 
Collective of authors (2000). Investigation of the causes of fires, Ministry of the Interior - Directorate of the Fire and Rescue Service of the Czech Republic in the FACOM publishing house, Jilové u Prahy, Prague.

KOVÁČOVÁ, L., VACKOVÁ M., (2014). Achieving of environmental safety through education of modern oriented society. In: 14th SGEM GeoConference on Ecology, Economics, Education And Legislation. SGEM 2014 Conference Proceedings. Vol. 2. DOI: 10.5593 / SGEM2014 / B52 / S20.001.

KROČOVÁ, Š., KAVAN, Š., (2019). Cooperation in the Czech Republic border area on water management sustainability In Land Use Policy. Volume 86, pp. 351-356. Elsevier. ISSN: 0264-8377. https://doi.org/10.1016/j.landusepol.2019.05.019.

KVARČÁK M., (2005). Basics of fire protection. 1st edition. Ostrava: Association of Fire and Safety Engineering in Ostrava. ISBN 80-86634-76-0.

MYTTON, J, GOODENOUGH, T., NOVAK, C. (1995). Children and young people's behavior in accidental dwelling fires: A systematic review of the qualitative literature In Safety Science, Elsevier BV, Vol. 20, Issues 2-3. ISSN: 0925-7535. DOI: 10.1016 / j.ssci.2017.03.019.

POKORNÝ, J., TOMÁŠKOVÁ, M., BALAŽIKOVÁ, M., (2015). Study of changes for selected fire parameters at activation of devices for smoke and heat removal and at activation of fixed extinguishing device. Prague: MM (Modern Machinery) Science Journal. pp. 764 - 767. ISSN 1803-1269 (Print), ISSN 1805-0476 (On-line). DOI: 10.17973 / MMSJ.2015_12_201558.

Statistical Yearbook of the Environment of the Czech Republic (2017). Ministry of the Environment. Prague: Czech Environmental Information Agency.

ŠENOVSKÝ M. et al., (2004). Basics of fire engineering. 1st edition. Ostrava: Association of Fire and Safety Engineering in Ostrava. ISBN 80-86634-50-7. 178s. 


\title{
Conceptualization of political extremism and radicalism:
}

\section{An outline of selected theoretical aspects of research}

DOI: $10.36682 / S S S \_2021 \_8$

\author{
Assoc. prof. PhDr. Rastislav Kazansky, PhD., EMBA \\ Department, institute Department of Security Studies \\ Faculty Faculty of Political Sciences and International \\ University Relations Matej Bel University \\ University \\ $\triangle$ Kuzmányho 1, 97401 Banská Bystrica, Slovakia \\ Email: rastislav.kazansky@umb.sk
}

Assoc. Prof. PhDr. Anton Hrubon, PhD.

\author{
Department, institute Department of Security Studies \\ Faculty Faculty of Political Sciences and International \\ University Relations Matej Bel University \\ University \\ Uz Kuzmányho 1, 97401 Banská Bystrica, Slovakia \\ Email: anton.hrubon@umb.sk
}

\begin{abstract}
Annotation
The presented paper follows selected approaches to the study of extremism and radicalization, which are an integral part of research into the conspiracy aspects. In our paper we deal with the specification and theoretical analysis of individual factors of radicalization and their interdependence. The aim of the paper is to synthesize the meaning of these phenomena, their conditionality, but also the differences. This research also aims to define the degree of security risk of extremism and radicalization.
\end{abstract}

\section{Key words}

Extremism, conspiracy, radicalization

\section{Introduction}

Technical terms used in security science, such as extremism and radicalism, are sometimes perceived as synonymous or confused. The fact that many scientists have linked radicalism to extremism is partly a direct consequence of the historical roots and trends of the concept.

If we look at the terms based on etymological research, the word "radical" entered the public debate in the 18th century, especially in connection with the French and American Revolutions and in the context of the Enlightenment (Schmid, 2013). The British politician Charles James Fox revived the Latin term "radix" and, emphasizing the turn to "original", used it to denote some of the far-reaching political reforms of the time. (Fadil et al., 2019) The term radicalism was used almost exclusively in the British and French revolutionary spheres, where it referred to anti-colonialism or even to antimonarchist ideas, phenomena or events, such as the independence of the United States or the Great French Revolution. In political science theories, the term radicalism later became entrenched as a phenomenon between the democratic center and extremist tendencies (Murinova, 2017).

It is noteworthy that the connotation of extremism does not appear to a greater extent in social and scientific discourse until the second half of the 20th century. Extremism is part of a long tradition dating back to antiquity in the history of political thought. In essence, it has existed since ancient times, and is 
defined by a marked deviation from the "middle", characterized as a measure of the extremes at both poles of the spectrum, which reject established rules and standards (Backes, 2006). Extremism finds its roots in Latin as "the most distant" or "most extreme" (Murínová, 2017).

One of the definitions of Slovak authors is the definition by Kotvanová (2013), according to which extremism is "an anti-systemic attitude, based on an extremely sharp ideology, which questions and destroys the existing democratic system of functioning society and attacks the system of fundamental rights and freedoms." (Kotvanová, 2013) Quite often this phenomenon is thematized in the media discourse in the typology of demonstrations by the media. Supporters of extremism oppose a democratic regime $^{1}$ in the country in which they are located. (Murínová, 2017) Political extremism is usually differentiated into right-wing in its various variations (otherwise also as the far right, ultra-right, neofascism and neo-Nazism) and left-wing (ultra-left). The terms mentioned above as the far right and the far left indicate a wide area of the constitutional-conformist margin, see Figure 1 below (Mikušovič, 2007). The former seeks to establish comprehensive rules that enshrine inequality, the superiority of race and specific citizenship, and authoritarianism. The ideas of left-wing extremism stem mainly from anarchism and communism, where the basis is equality and the liberation of man from government and other pressure. The aim is to build a society based on non-democratic principles,

Radicalization as a process in which its object gradually accepts radical ideology in the broadest sense of the word is unique for each individual. Radicalism questions the legitimacy of established norms and policies, which in itself does not yet lead to violence. The phenomenon includes, for example, individuals who reject the values of society but abide by the law and try to bring about change through political dialogue. However, the radicalization process tends to involve a combination of shared cognitive and behavioral characteristics or structural complaints. (European institute for peace, nd) For example, in recent years, Europe has seen attacks by both right-wing extremists and Islamist extremists. ${ }^{2}$ (Europol, 2020) The term radical became the equivalent of extremist right-wing politics and activism, which was partly motivated by anti-socialist ideas. For this reason, we should conclude that although the term "radical" originally referred to "the noble struggle for freedom against the oppressors," in the second half of the 20th century it became a term that could, so to speak, be identified with antiliberal views. The term is increasingly becoming a concept, referring to the extreme or extreme aspects of the political spectrum. In this sense, since the 1950s, the meaning of radicalism has become internally inadequate and dangerously intertwined with open extremism, which are two different concepts in terms of content (Frissen, 2019).

In terms of political practice extremism differs from radicalism, for example, in that extremists accept violence as a legitimate means of achieving political goals without necessarily using violence themselves (Murínová, 2017).

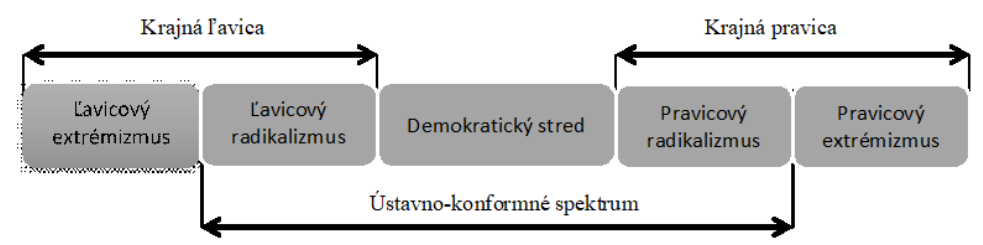

Figure 1: Constitutional-conformal spectrum according to R. Stöss modified by M. Mareš (Mikušovič, 2008)

\footnotetext{
${ }^{1}$ Extremists reject the equality of citizens, differ in their attitudes in major topics such as economics, secularization of society, do not respect the main principles of democracy (sovereignty, human rights and freedoms, plurality, etc.) (Murínová, 2017).

${ }^{2}$ In the case of right-wing extremists, we speak e.g. about Anders Breivik in Norway or neo-Nazis in Germany (Reuters, 2011) or Islamic extremists in Brussels (The Guardian, 2014) or Copenhagen (BBC, 2015).
} 
Extremism involves the categorical thinking we versus them, often driven by the dense closed environment of like-minded individuals. Approving the use of violence, even against the civilian population, can further alienate an individual from society. At the same time, it represents an important turning point in which an individual can psychologically prepare for the use of violence. (European Institute for Peace, nd - in our study the term violent extremism is also mentioned). ${ }^{3}$ This phenomenon involves violent behavior based on an ideology shared with at least a limited group of individuals. Violent extremism includes willingness, as well as training, preparation and the actual conduct of acts of violence against civilians. (ICSR, 2020) Many times it has been linked to terrorism. Terrorists show signs of strong disconnection from society and tend to degrade or dehumanize (victims) their victims. Historically, individuals have turned to terrorism when they have seen no other way to achieve a specific political goal (European Institute for Peace, nd).

Although terrorism is currently usually associated mainly with the right-wing spectrum (most often religious fanaticism), by way of illustration, Greece, Italy and Spain, for example, have been the epicenter of attacks by left-wing and anarchist terrorists in their development. (Europol, 2019) The most common targets of left-wing and anarchist terrorists and extremists were private enterprises, critical infrastructure and public as well as government institutions. In the vast majority of cases, the perpetrators remained unknown. The number of arrests on suspicion of left-wing or anarchist terrorism in 2019 has more than tripled compared to previous years. Most of the arrests were linked to violent demonstrations and confrontations with security forces in Italy. The detention was due to a suspicion of preparing for and committing a terrorist attack, often in combination with membership in a terrorist group. The men arrested made up the largest group of the total number of arrests, see graphic Figure 2 (Europol, 2020).

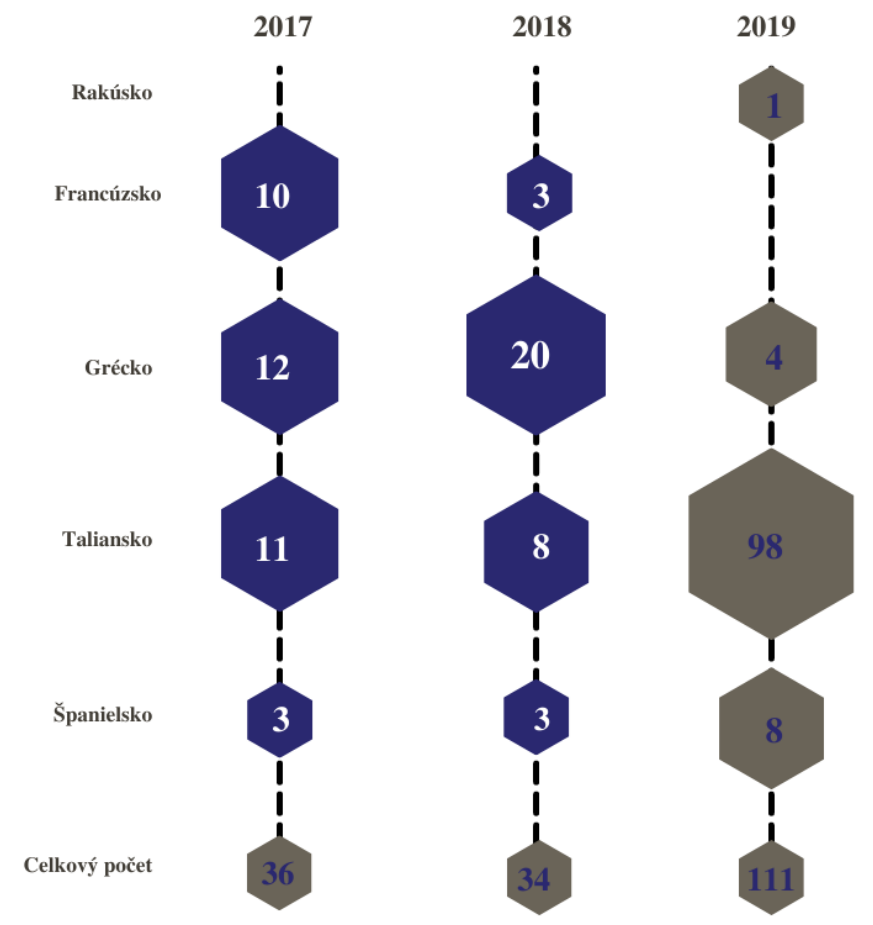

Figure 2: Attacks by right-wing and anarchist terrorists during 2017-2019 (Europol, 2020)

\section{Factors leading from radicalization to violent extremism}

Radicalization as a phenomenon does not necessarily lead to violence, but is one of several risk factors required for this transition process (Horgan-Braddock, 2010). It thus includes global, sociological and political factors, as well as individual and psychological causes. (European Institure for Peace, nd) Hogan and Braddock announce that it is a process of gradually experiencing a commitment to extremist political or religious ideology (Horgan-Braddock, 2010). There is no hierarchy of factors that would

\footnotetext{
${ }^{3}$ In the English original violent extremism.
} 
automatically lead to violence. The causes vary from individual to individual. However, in the process of radicalization, there are several common factors, mediators, and events that may (but may not) result in violent extremism (Awan et al., 2011).

The European Institute for Peace has defined four factors and causes that potentially lead from radicalization to violent extremism (European Institure for Peace, nd):

- Structural factors (SF). These are long-term, fixed factors that bring a sense of injustice to the minds of individuals. These include, for example, demographic imbalances, poverty, inequality, discrimination or the polarized environment and transition societies. These conditions - whether real or perceived - create a favorable environment for radicalization. ${ }^{4}$

- In addition, there are facilitating or accelerating causes (UF) that facilitate the radicalization process by simply accessing information and other resources (eg the Internet).

- Motivating factors $(\boldsymbol{M F})$ through indoctrination they bring the individual closer to extremism. This category includes, for example, radical political leaders or radical preachers who incite hatred or intolerant beliefs or ideologies. In this phase, the environment of the individual creates the so-called the Manichaean gap between "us" and "them". By creating these black and white differences, radicalization can contribute to the fundamental polarization of society and social conflicts.

- The final decision to engage in violence requires further personal transformation. Research has highlighted the importance of triggering events (SUs) - these are key actions that have an intense emotional impact on an endangered individual. These events can encourage someone to take the last step on the path to violent extremism. ${ }^{5}$ This is considered when an individual chooses to commit violence as a means of expressing his or her faith. (European Institure for Peace, nd) We will characterize the mentioned groups of factors in more detail in the following article, which will show how radicalization can occur and what impulses we can change, resp. eliminate imminent radical behavior.

\section{Risk factors leading to radicalization}

According to Frissen, not only institutions but also scientists have identified a diverse set of individual, group and socio-communication mechanisms as potential root causes of radicalization. (Frissen, 2019) Ricolfi emphasizes that the motivation to engage in suicide missions, for example, can be found in a "cocktail of feelings" that includesa desire for revenge, resistance and a sense of responsibility towards the victims. (Ricolfi, 2005) In the process of radicalization, stretch marksda several complex so-called risk factors. No single factor can be described as causal. A combination of risk factors is always needed to explain radicalization (Precht, 2007). These can be divided into three categories:

- push factors (individual or "life cycle" characteristics that increase the likelihood of radicalization),

- pull factors (characteristics of an extremist group or context that make radicalization attractive),

- catalysts (so-called event accelerators)

Push and pull factors and catalysts form the breeding ground for radicalization (see Table 2). These risk factors are typical of many individuals, but only a very small percentage of them eventually become fully radicalized (Precht, 2007). According to Pauwels, there is also no deterministic relationship between certain risk factors and violent extremism. Risk factors affect the likelihood of escalating into violent extremism, but do not in themselves explain why some individuals become radicalized and others do not in similar situations. Due to push factors, individuals are prone to radicalization, which can also be of the violent type. In particular, identity appears to be a central factor that can be a strong determinant towards (violent) radicalization. Factors that can "pull" individuals come from the external environment. Catalysts are elements that accelerate action, in this case radicalization. They mostly contribute to (violent) radicalization by confirming existing beliefs. Compared to long-term push and

\footnotetext{
${ }^{4}$ At the same time, it is important to emphasize that not all individuals who have this feeling of injustice are becoming radicals. Few are inclined to violent extremismand even less to terrorism. This makes the start of the radicalization process "difficult to predict". (European institute for peace, nd)

${ }^{5}$ It can be the death of a neighbor, emotional events that cause anxiety in a person.
} 
pull factors, catalysts can start and accelerate the contracted radicalization process very quickly (Pauwels, et al., 2014).

Table 2: Overview of risk factors of violent extremism identified in the literature (Pauwels, et al., 2014)

\begin{tabular}{|c|c|c|}
\hline \multirow{9}{*}{ 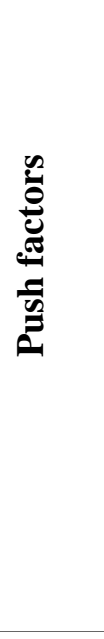 } & \multirow{3}{*}{$\begin{array}{l}\text { Individual } \\
\text { characteristics and } \\
\text { features }\end{array}$} & Psychopathological features \\
\hline & & $\begin{array}{l}\text { Socio-demographic features (age, } \\
\text { place of residence, sex }, . . \text { ) }\end{array}$ \\
\hline & & Personality traits \\
\hline & \multirow{3}{*}{$\begin{array}{r}\text { Socio- } \\
\text { psychological } \\
\text { mechanisms }\end{array}$} & $\begin{array}{cc}\text { Perceived } & \text { injustice } \\
\text { (discrimination, deprivation) } & \end{array}$ \\
\hline & & $\begin{array}{l}\text { Perceived group threat (loss of } \\
\text { group identity) }\end{array}$ \\
\hline & & Perceived uncertainty \\
\hline & \multirow[t]{2}{*}{$\begin{array}{l}\text { Social } \\
\text { mechanisms }\end{array}$} & $\begin{array}{l}\text { Searching for social inclusion } \\
\text { (loneliness) }\end{array}$ \\
\hline & & Searching for identity and meaning \\
\hline & Emotions & $\begin{array}{l}\text { Fear, frustration, hatred, anger, } \\
\text { contempt, desire for revenge ... }\end{array}$ \\
\hline \multirow{2}{*}{ 三 } & Extremist groups & $\begin{array}{l}\text { Meeting social and psychological } \\
\text { needs }\end{array}$ \\
\hline & $\begin{array}{l}\text { The system of } \\
\text { radical faith }\end{array}$ & Ideological recognition \\
\hline \multirow{4}{*}{$\overbrace{\frac{n}{n}}^{\frac{\pi}{\pi}}$} & Trigger events & Change of personal or social events \\
\hline & Violence & The need for excitement and kicks \\
\hline & $\begin{array}{l}\text { Biographical } \\
\text { availability }\end{array}$ & Lack of social ties \\
\hline & Important people & $\begin{array}{l}\text { Beliefs from friends, family, } \\
\text { influencers }\end{array}$ \\
\hline
\end{tabular}

The factors identified by the European Institute for Peace in the previous subchapter can be explicitly extended to the views of authors dealing exclusively with radicalization. Their observations will deepen and expand the issue of variables created by Precht (2007). Based on Sageman, it is important to note that numerous analyzes of the socio-demographic environment of radicals and terrorists (ie the micro level) have shown that radicals are neither poor nor rich, that they are not exclusively men, and that education levels are not important prerequisites for radicalization (Sageman, 2004b).

One of the authors dealing with these issues is Kruglanski, who analyzed radicalization from an individual-psychological point of view. This is the lowest level (micro level), where we talk about pressure factors that force a person to change. Models in this area of research focus primarily on psychopathological, cognitive and emotional traits that contribute to the process of radicalization of the individual. ${ }^{6}$ According to Kruglanski, studies of radicalization through psychology and psychiatry are more specifically aimed at mapping psychological vulnerabilities that make an individual prone to gradually engage in a tangle of violent extremism or terrorism (Kruglanski et al, 2014).

${ }^{6}$ Previous research in this area has been carried out by Kruglansky. In his work "Suicide Bombers' Motivation and the Quest for Personal Significance"various motivations are defined. Several authors emphasize exceptional motivations.For example, Sageman's 2004 work on terrorist networks highlighted the desire for emotional and social support for Muslims in European diasporas who feel rejected and alienated by local societies. In 2005, Pape highlighted opposition to foreign occupation as a major motivating force. Spekhard and Akhmedova attributed this role to personal loss and trauma. Nasra Hassan concluded that the main motivation for Hamas terrorists was to enter the "Paradise... Presence in the Prophet Muhammad and harvest the harvest for participating in the Holy War." (Kruglanski, et al., 2009) 
An intuitive first reaction to the discussion of violent extremism and terrorism is that perpetrators must be mentally disturbed or at least psychologically abnormal. (Silke, 2008) Studies range from analyzes of ideological indoctrination to elements such as childhood trauma, (sexual) abuse and adolescent development patterns. (Frissen, 2019) A substantial set of individual psychological causes has been widely criticized for proving inconsistent. (Borum, 2011a) Nevertheless, there are several fundamental concepts at the individual psychological level, about which there is consensus in the literature. For clarity, let's summarize them in the following points:

- Terrorism expert Kruglanski argues that the process of radicalization can vary from individual to individual. The search for personal meaning is a general motivating force that is the basis of all radicalization processes, ie "the basic desire to have meaning, to be someone, to have respect". So we are talking about the so-called searching for meaning ${ }^{7}$ (Kruglanski et al, 2014, p. 73).

- Another typical individual psychological cause, which is well substantiated in the literature and which is to some extent related to the previous one, is the cognitive opening hypothesis ${ }^{8}$. Cognitive opening refers to a mental state in which a person is highly receptive to certain, new, radical, or extremist ideas. It is the result of a personal crisis, disappointment or even a loss of significance (King-Taylor, 2011). Like the search for meaning, cognitive openness is considered part of all radicalization processes. Recent studies indicate e.g. to link cognitive opening with religion in a broader sense, specifically with Salafist jihadism (Frissen, 2019).

- The growing number of recorded cases leads to discourse in the discourse to claim that criminal crime coincides with terror. The analysis of terrorist profiles increasingly suggests that criminal behavior precedes many cases of current radicalization. ${ }^{9}$ In a recent publication, Gartenstein-Ross and Blackman (2019) made very similar observations. They found that in some cases of radicalization, individuals did move from one form of violent extremism to another. They called this phenomenon "marginal fluidity"10. As they state, "edge smoothness" is, in fact, so common that it should be seen as an independent and important path to radicalization. Specific examples of the fluidity of margins are when individuals transform from neo-Nazism to militant Islamism (Gartenstein-Ross \& Blackman, 2019). ${ }^{11}$ Nevertheless, these findings are still too premature to fully understand this marginal path of "fluidity" of radicalization. Therefore, the phenomenon needs to be further investigated with a view to the future (Frissen, 2019).

- A well-established concept at this level is also the process of self-radicalization ${ }^{12}$. As Frissen points out, self-radicalization (the name is also self-radicalization) can be thought of as a process in which an individual radicalises in isolation at home. ${ }^{13}$ through the pursuit, acceptance, and mastery of extremist ideology (Frissen, 2019). This phenomenon has become known as "bedroom radicals" or

\footnotetext{
${ }^{7}$ English original - significant quest. The motivational analysis of suicidal terrorism is rooted in the concept of the search for meaning. It is proposed that heterogeneous factors be identified as personal causes of suicidal terrorism (eg trauma, humiliation, social exclusion), various ideological reasons that justify it (eg liberation from foreign occupation, defense of a nation or religion) and social pressures. (Kruglanski, 2009)

${ }^{8}$ From the English original cognitive opening.

${ }^{9} \mathrm{An}$ analysis by Basr and the 2016 team found that $65 \%$ of the people in their database were in fact involved in violent crime before being radicalized as terrorists. One example referring to the link between crime and terror is the el-Bakraoui brothers and the network responsible for the attacks in Paris and Brussels on 13 November 2015 and 22 March 2016 (Basra, et al, 2016) Also Van Ostaeyen (2016) he said that "the history of Zerkani's potential newcomers to petty crime and gangsterism naturally provided them with better trade operations in covert operations that helped them travel easily to and from Syria." (Van Ostaeyen, 2016)

${ }^{10}$ English original fringe fluidity.

${ }^{11}$ These authors argue that before an individual can make a real transition, there must be sufficient ideological convergence between the margins. However, as they add, it is still not clear how much "overlap" is exactly necessary to allow such a transition. One hypothesis is that a shared external group is crucial. It is clear that the rejection of the center, the common foundations, and especially the common hostility toward Jews, lie at the epicenter of cases of Nazi-jihadist "fluency." (Frissen, 2019)

${ }^{12}$ English original self-radicalization.

${ }^{13}$ The process of self-radicalization can be understood as a process in which individuals with minimal (perhaps even no links to terrorist networks) are drawn into extremism or terrorism through a bottom-up rather than a "topdown" recruitment process. (Frissen, 2019)
} 
"bedroom radicals" (Ahmed-George, 2016). In this context, it is said that self-radicalization is mainly driven by online information search behavior, which means that individuals actively seek out radical and extremist content on the Internet and increasingly align their personal worldviews with views on literature and videos they reflect. The Internet and current information and communication technologies are seen as tools that play a crucial role in this (Frissen, 2019).

- One last but very strong aspect at the individual level from a psychological perspective is Dean's development of tools for assessing neurocognitive risks (RAT for short). This RAT ${ }^{14}$ The tool is designed to facilitate the early detection of individuals who may have the potential to engage in violent extremist acts such as terrorism (Dean, 2014). However, Frissen emphasizes that the neurobiological data in this state of knowledge are still too embryonic to thoroughly predict and explain radicalization ${ }^{15}$ (Frissen, 2019).

If we move on to the last group of factors, which are catalysts, compared to push and pull factors, they can start very quickly and accelerate the radicalization process. These are, for example, triggering events that give the impression of intense injustice. Silke emphasizes that they can provoke great anger and a strong desire for revenge and retaliation (Silke, 2008). Some events can be so impressive that participating individuals need to rethink their place in society. (Pauwels, 2014) The risk assessment of radicalization via the Internet offers four considerations that not only enrich our understanding of progress in radicalization in the online world, but also guide us in identifying relevant (already mentioned) factors and indicators (Neo et al., 2017). These are the following points:

1. The first reflection on the individual examines the motivations and belief systems that encourage the individual to engage in behavior related to online radicalization (eg identification of complaints based on perception). Motivation can take many forms and provide important information about an individual's susceptibility to terrorist stories.

2. The second consideration of the online environment defines the informational, instrumental, and emotional support that the Internet provides to the individual, while interacting with radical content and like-minded individuals online.

3. The third consideration is the interactions between the individual and the online environment. Factors in this consideration are compiled based on how individuals interact in terrorist online communities.

4. Finally, the last consideration of the security element examines the factors that reduce the likelihood of an individual advancing on the path of radicalization. The theoretical argument is that not all individuals become radicalized after being exposed to radical online propaganda.

\section{Conclusion}

Overall research on radicalization now generally recognizes that radicalization (or extremism or terrorism) is not the result of psychopathology, such as depression or mood disorders, nor is it exclusive to emotionally disturbed individuals or lunatics. After all, as Pauwels emphasizes, carrying out a terrorist attack requires a high level of self-control, discipline and rationality (Pauwels, 2014). Psychotic behavior, trauma, or personality disorders make individuals less suitable for working in a highly demanding organization (Sageman, 2008). This does not mean that these individuals are never part of extremist movements, but only exceptionally and are usually denied a central position in it. Only for the so-called of lone wolves and loners, the picture may differ. Radicalization is an individual long time frame and within it there can be a radical change in personality traits. However, in the words of psychiatrist Jerrold Post, it is not individual psychopathology, but group, organizational and social psychology with a special emphasis on collective identity that provides the strongest lens through which to understand terrorist psychology and behavior (Post, 2007).

\footnotetext{
${ }^{14}$ This work is important because Dean (2014) suggested that RAT is able to reliably distinguish between violent and nonviolent radicalization by distinguishing individuals who only talk about violent extremism from those who are determined to take violent action. (Dean, 2014)

${ }^{15}$ According to Frissen, the studies carried out have tried to understand what happens in the brain during the process of radicalization. It is typical of the paradigm of individual psychological research that most studies in this area have a solid foundation in the tradition of radicalization of the faith. At the end of the study, some researchers argued that given brain data should be considered neuro-biological support for Kurglanski's (2014) meaningfinding hypothesis, as personal meaning or self-worth may be associated with self-presentation, sensitivity to reward, and sacred values. (Frissen, 2019)
} 
That is why the group-level model is given as an alternative to an individual-centered approach. Studies following this research agenda emphasize concepts such as collective identity, collective complaints, their norms and values, and group recruitment. Indeed, according to Spears, numerous studies have suggested that social ties, interpersonal networks, and intergroup influences are central to the radicalization of individuals, and can be said to be pull factors. It is the collective identity that can be very generally understood as the subjective feeling of identifying people with a group (Spears, 2008). More specifically, collective identity can be defined as the process by which social actors recognize themselves and other actors recognize them as part of wider groupings and develop emotional ties to them (Della Porta-Diani, 2006). Collective identity is constructed on the basis of known symbols, worldviews, lifestyles and stories. Studies in this area of research claim that collective identity creates strong bonds between sympathizers in the group, while differentiating itself from members from other social categories. (Singerman, 2004) As a result, collective identity has become a crucial precursor to engaging in (collective) action and (violent) radicalization. (Della Porta-Diani, 2006) In this case, the pull factor can be easily identified as a factor of extremist groups that often saturate basic social and psychological needs (Bjørgo, 2002, 2012): First, it is not very likely that someone will join to an extremist group when he is satisfied with the current personal or political situation and when the social status quo does not provoke his frustration. Secondly, extremist groups need to offer something

Wiktorowicz proposed a "supply and demand chain" applied to an extremist group, where, on the one hand, complaints such as insecurity, group threats and a lack of social integration, which form the breeding ground, are perceived. Sometimes these demands can be so urgent that personal resistance to violent extremism begins to fall apart and create so-called cognitive opening. This suggests that individuals are becoming prone to new ideas and perspectives, including extremist views that would otherwise be immediately rejected. If the nature of the (perceived) complaints coincides with what some extremist groups have to offer, radicalization can take place. (Wiktorowicz, 2004) Pauwels emphasizes that the use of language and symbols places radical demands on a certain interpretive framework. At the same time, they seek to align their frameworks with perceptions and complaints, which already exist in the target population. Successful extremist frameworks offer alternative and simple ideological explanations for perceived wrongs, point to causes and consequences, and emphasize one's own political and social effectiveness. They are very well aware of the complaints of potential members and offer them a response by placing these feelings in a broader extremist picture. These groups are attractive to seeking and frustrated individuals because they seem to offer answers to all their questions and problems (Pauwels, 2014). Also, the particular ideology of an extremist group is usually not a central factor leading to violent extremism. The real reasons for joining an extremist group are, in principle, of a social nature. In fact, most individuals who join an extremist group ${ }^{16}$ (Sageman, 2004).

The main focus of interest in the current wave of radicalization research is the role played by the Internet, conspiracies and their role in the radicalization process. According to some authors, the Internet and social networks have the main responsibility for the radicalization of individuals (Alava, et al, 2017). In any case, radicalization is an increasing security challenge. Thanks to new technologies and the growing polarization of society, this is a serious threat throughout the European Union.

This work was supported by the Agency for the Support of Research and Development on the basis of Contract no. APVV-20-0334.

\section{Literature}

AWAN, AN et al. (2011). Radicalization and media: Connectivity and terrorism in the new media ecology. New York: Routledge. 168 s. ISBN 978-0-415-64199-9.

\footnotetext{
${ }^{16}$ According to Roy (2008), the success of organizations like Al Qaeda is not based on their development as a political organization drawing on a particular ideology, but rather on the creation of a story.
} 
BACKES, U. (2006). Limits of political freedom in democratic constitutional states: a comparative study on Germany, France and the USA. In the Journal of Totalitarianism and Democracy. [online]. 2006. p. 265- 283 [cit. 2021-06-03]. Available online: <https://www.ssoar.info/ssoar/bitstream/handle/document/31061/ssoar-2006-2-backeslimits_of_political_freedom_in.pdf?sequence=1>. ISSN 1612-9008.

DEAN, G. (2014). Neurocognitive Risk Assessment for the Early Detection of Violent Extremists. Cham: Springer, 2014. 112 p. ISBN 978-3-319-06719-3.

DELLA PORTA, D. (2009). Social movement studies and political violence. In The Center for Studies in Islamism and Radicalization. [online]. 2009 [cit. 2021-21-03]. Available online: <https://pure.au.dk/portal/files/32769489/H_fte_>. ISBN 978-87-92540-05-8.

EUROPOL. (2018). European Union terrorism situation and trend report. [online]. 2018. [cit. 2021-2602]. Available online: <https://www.europol.europa.eu/activities-services/main-reports/europeanunion-terrorism-situation-and-trend-report-2018-tesat-2018>. ISBN 978-92-95200-91-3. DOI 10.2813 / 00041. QL-AJ-18-001-EN-N

EUROPOL. (2019). European Union terrorism situation and trend report. [online]. 2019. [cit. 2021-2602]. Available online: <https://www.europol.europa.eu/activities-services/main-reports/terrorismsituation-and-trend-report-2019-te-sat>. ISBN 978-92-95209-76-3. DOI 10.2813 / 788404

EUROPOL. (2020. European Union terrorism situation and trend report 2020. [online]. 2018. [cited 2021-19-04] .Available on the Internet: <https://www.europol.europa.eu/activities-services/main reports / european-union-terrorism-situation-and-trend-report-te-sat-2020> .FADIL, N. et al. 2019. Radicalization: Tracing the Trajectory of an "empty signifier" in the Low Lands. Radicalization in Belgium and the Netherlands, Critical perspectives on Violence and Security, Leiden: Leiden University, 2019. DOI 10.5040/9781788316187.0007, 10- 34 p.

FRISSEN, T. (2021). Internet, the great radicalizer? Exploring relationships between seeking for online extremist materials and cognitive radicalization in young adults: výzkumná práca. Leuven, KU, 2021. $13 \mathrm{p}$.

GARTENSTEIN- ROSS, D.- BLACKMAN, M. (2019). Fluidity of the Fringes: Prior Extremist Involvement as a Radicalization Pathway. In Studies in Conflict \& Terrorism. [online]. 2019, vol. 0, no.0 [cit. 2021-16-04]. Available online: 〈https://doi.org/10.1080/1057610X.2018.1531545>. HORGAN J.- BRADDOCK, K. (2010). Rehabilitating the terrorists ?: Challenges in assessing the effectiveness of de-radicalization programs. In Terrorism and Political Violence. 2010, Vol. 22, no. 2 p. 267-291. [cit. 2021-10-03]. Available online: <https://doi.org/10.1080/09546551003594748

KRUGLANSKI, A. et al. (2009). Fully committed: Suicide bombers' motivation and the quest for personal significance. In Political Psychology. [online]. 2009, vol. 30, no.31 [cit. 2021-15-04]. Available online: 〈https://doi.org/10.1111/j.1467-9221.2009.00698.x>.

MIKUŠOVIČ, D. (2007). Non-parliamentary far right in Slovakia: bachelor thesis. Brno: Masaryk University, 2007. $62 \mathrm{p}$.

MURÍNOVÁ, Z. (2017). Political extremism in our country. Basic information about current extremism in Slovakia. [online]. FICE Slovakia, 2017. 23 p. [cit. 2021-07-03]. Available on the Internet: <http://prevenciaad.sk/wp-content/uploads/2013/11/Politick\%C3\%BD-extr\%C3\%A9mizmusun\%C3\%A1s-z\%C3\%A1kladn\%C3\%A9 -inform\% C3\% A1cie-os\% C3\% BA\% C4\% 8Dasnom-extr\% C3\% A9mizme-na-Slovenska-2.pdf

NEO, SL (2020). Detecting markers of radicalization in social media posts: the role of personcentric and psychosocial risk factors, and protective factors: diplomová práca. Singapore: Nanyang Technological University, 2020. 305 p.

PAUWELS, L. et al. (2014). Explaining and understanding the role of exposure to new social media on violent extremism: an integrative quantitative and qualitative approach. In Academia Press. [online]. 2014. p. 233 [cit. 2021-11-04]. Available online: <http://hdl.handle.net/2078.1/156547>. ISBN 978-9038-22398-8 
PRECHT, T. (2007). Home grown terrorism and Islamist radicalization in Europe: research report. Copenhagen: Danish Ministry of Justice, 2007. 98 p.

SAGEMAN, M. (2004a Understanding terror networks. Pennsylvania: University of Pennsylvania Press, 2004. 232 pp. ISBN-10: 081-2-23808-7.

SAGEMAN, M. (2008). Leaderless Jihad: terror networks in the twenty-first century. Pennsylvania: University of Pennsylvania press, 2008. 209 p. ISBN-13: 978-0-8122-4065-8.

SILKE, A. (2008). Holy wars: Exploring the psychological processes of Jihadi radicalisation. In European Journal of Crimininology. [online]. 2008, vol. 5, no. 1 [cit. 2021-14-04]. Available online: <https://doi.org/10.1177/1477370807084226>.

SCHMID, AP (2013) Radicalization, De-Radicalization, Counter-Radicalization: A Conceptual Discussion and Literature Review. In ICCT Research Paper. [online]. The Hague. 2013. [cit. 2021 -0403]. Available on the Internet:https://www.icct.nl/download/file/ICCT-Schmid-Radicalisation-DeRadicalisation-Counter-Radicalisation-March-2013.pdf

WIKTOROWICZ, Q. (2004). JOINING THE CAUSE: AL-MUHAJIROUN AND RADICAL ISLAM. [online]. 2004 [cit. 2021-22-03]. Available online: <https://securitypolicylaw.syr.edu/wpcontent/uploads/2013/03/Wiktorowicz.Joining-the-Cause.pdf >. 


\title{
Practical and Epistemiological Basis for Research into the Security Threats of Terrorism and Radicalization in the Online Space
}

DOI: 10.36682/SSS_2021_9

\author{
Assoc. Prof. PhDr. Rastislav Kazansky, PhD. \\ Department, institute Department of Security Studies \\ Faculty Faculty of Political Sciences and International \\ University Relations Matej Bel University \\ University \\ $\triangle$ Kuzmányho 1, 97401 Banská Bystrica, Slovakia \\ Email: rastislav.kazansky@umb.sk
}

Assoc. Prof. PhDr. Lucia Rysova, PhD.

\author{
Department, institute Department of International Relations \\ Faculty Faculty of Political Sciences and International \\ University Relations Matej Bel University \\ University \\ $\triangle$ Kuzmányho 1, 97401 Banská Bystrica, Slovakia
}

Email:lucia.rysova@umb.sk

Mgr. Nina Mijoč

Department, institute Department of Security Studies

Faculty Faculty of Political Sciences and International

University Relations Matej Bel University

University

$\triangle$ Kuzmányho 1, 97401 Banská Bystrica, Slovakia

Email:nina.mijoc@unidu.hr

\begin{abstract}
Annotation
The paper deals with the definitive basis for research on terrorism and radicalization, with emphasis on the evolution of the content of the term and terminological refinement. The aim of the paper is to find and identify research bases for research into online space and the penetrating radicalization and connection with terrorism. Through analysis, synthesis, comparison and deduction, we try to identify the main research issues in this security threat.
\end{abstract}

\section{Key words}

radicalization, terrorism, terminology, typology of terrorism

\section{Introduction}

Discussions on how to define the phenomena of terrorism and radicalization are often limited by normative and politicized ideas. It is the fragmentation of the social sciences that points to a serious obstacle to the unification of the joint research agenda. The social sciences are not strictly exact sciences. Nevertheless, a precise definition of socio-scientific concepts is essential, as G. Dean points out in his work Neurocognitive Risk Assessment for the Early Detection of Violent Extremists, which suggests the need for precise definitions because, as something is defined, it is shaped by how applied in practice (Dean, 2014). Looking at the definitions of key terms used in the thesis, we notice that the concepts of radicalization, terrorism and extremism are vaguely vaguely inaccurate, inconsistent and controversial. This brought with it a set of ontological, methodological and ideological problems and challenges in the 
study of these concepts and specifically their interrelationships. Often these concepts are interchanged in practice due to their small differences, and therefore it is necessary to find different features but also the connection and interaction between the concepts (Frissen, 2019). Terrorism and the persistent issue of definition in the 21 st century.

Perhaps most generally but less precisely, we could determine that terrorism involves the use of violence or the threat of its use as a means of achieving some effect in a political context. (Horgan, 2005) This vague lesson points to the complexity of definition and controversy in the literature, as it is extremely difficult to grasp what the term clearly represents. (Dean, 2014, p. 15) This deficit is especially visible on a practical level, namely in the security strategies of states where there is no uniform definition of terrorism, only its various types such as environmental terrorism, cyberterrorism, ideological terrorism, etc. (Ivančík- Nečas, 2019).

This aporema of terrorism has been explored as a discipline plagued by an epistemic, socio-structural, and semantic crisis since its first publication in the 1970s (e.g., Crenshaw in 1972). It was often heard that this area got stuck in the so-called a political game in which the term terrorist is referred to as a pejorative sign for a political opponent and does not coincide with the dominant political discourse of those responsible for seeking a definition (Frissen, 2019). Terrorism is a French word derived from "terrorism", and if we look deeper, the roots of the word are found in Latin as "fear" or "horror" (SinghAgarwal, 2017). Terrorism can therefore be described as the unofficial or unjustified use of violence and intimidation in pursuit of political objectives. It could also be noted as the use of violence and threats for intimidation and coercion, especially for political purposes. Terrorism can also be seen as an asymmetric form of conflict, as it offers coercive force with many of the benefits of military force at a fraction of the cost (Dictionary, 2021).

The first recorded evidence that terrorism is being heard by politicians and society has been in the French vocabulary since the 14th century, and since the 16th century we have seen that the term is reaching various languages around the world. The historical event of the explosion of the church in the village of Teror, located on the island of Gran Canaria at the beginning of the 18th century, also contributed to the seriousness of this phenomenon. Thanks to this act, destruction, paralysis of society and an increase in fear have been attributed (Ivančík, Nečas, 2019). That terrorism gets into the language of politicians and societies are already in the French dictionary during the 14th century, in addition to the 16th century we perceive that the term is getting into various languages around the world. The historical event of the explosion of the church in the village of Teror, located on the island of Gran Canaria at the beginning of the 18th century, also contributed to the seriousness of this phenomenon. Thanks to this act, destruction, paralysis of society and an increase in fear have been attributed (Ivančík-Nečas, 2019). that terrorism gets into the language of politicians and societies are already in the French dictionary during the 14th century, in addition to the 16th century we perceive that the term is getting into various languages around the world. The historical event of the explosion of the church in the village of Teror, located on the island of Gran Canaria at the beginning of the 18th century, also contributed to the seriousness of this phenomenon. Thanks to this act, destruction, paralysis of society and an increase in fear have been attributed (Ivančík-Nečas, 2019).

\section{Stages of terrorism development}

Several subjective opinions and views on the definition differ from the profession, the sphere of interest of the authors and, of course, the period when the definition was classified. In the literature by Ivančík and Nečas, we noted several proposals for the classification of the definition according to historical contexts divided into five stages (Ivančík, Nečas, 2019):

1. stage has been depicted since ancient times, where the notion of terror prevailed as a tool against the individual in an effort to incite fear in society, such as in conquests, civil wars or in an effort to suppress rebellions and uprisings. This stage ends with the Great French Revolution, a major breakthrough in the understanding of terrorism. The main tools were verbal forms of coercion such as intimidation, followed by a system of punishing offenders and, last but not least, political deliberate killing. A form of so-called state terrorism, where citizens have become the target. It was 
at this stage that, for the first time, the steady use of the term terror in dictionaries was noted as a regime where the main goal was the continuous intimidation of citizens (Singh, Agarwal, 2017).

2. stage it covers the period up to the beginning of the Second World War and is visible not only on the European continent, but also worldwide. We study the departure from the state terrorism prevalent in France to the anti-state terrorized by anarchic radical organizations such as the Irish Republican Army, the terror promoted by the so-called They are waiting ${ }^{17}$ or the Ku-Klux-Klan. However, in the interwar period, the already mentioned state terrorism was reborn. Terrorism has been reinforced by technological developments, which have brought new weapons on the one hand, but also tools to combat it on the other.

3. stage visibly strengthened state terrorism, especially in Germany, where the Japanese, for example, were later inspired to use the methods of terrorism with catastrophic consequences on the lives of civilians. The main characteristics were the cruelty of the armies, the perversity of racism, rude methods of fighting, the looting of the country, and the dead civilians of hostile societies seemed to be legitimate targets that were not found guilty.

4. stage is the next stage of development in response to the end of World War II, which did not secure peace or stop terrorism. The Cold War era, accompanied by decolonization and nationalist influences in Africa, Asia and the Middle East, was the cradle of international terrorism. Several terrorist organizations have established themselves on each continent ${ }^{18}$, whose activities have spread to neighboring countries and have begun to consolidate power in various violent ways.

5. stage pointed to unresolved disputes between ethnic groups and religious groups in the former Soviet Union. The noticeable features for this phase are the strengthening of state terrorism, financial support, the readiness of terrorist groups, the target are civilians whose security was no longer certain, and the main intention is to provoke global fear with an impact on the individual. It is the primary source that "citizens who do not trust their own government and political system because they believe they cannot protect them are becoming easy prey for various forms of extremism and radicalism." (Ivančík, Nečas, 2019, p. 37) It is this stage that points to a new form of terrorism, where individuals or the so-called lone wolves who are not part of a terrorist group,

The selected evolutionary line pointed to the fact that terrorism is a historical phenomenon that is constantly evolving and improving the mechanism affecting the psyche of the individual. The phenomenon, which has improved and gained strength over the centuries, still threatens society today as it did in the past. (Ivančík- Nečas, 2019) Terrorism does not know the scope of its scope and is spreading rapidly. (Baričičová- Ivančík, 2019) Institute for Economics and Peace (IEP) ${ }^{19}$ sees the issue of defining the term terrorism as not a very simple matter. "There is no single internationally accepted definition of what constitutes terrorism, and the terrorist literature is rich in competing definitions and typologies." (IEP, 2020, p. 9) Despite its existence, no definition has yet been found that is internationally recognized and respected.

The first attempt to codify the clear wording of the definition of terrorism dates back to 1937, when, at the signing of the League of Nations Prevention and Suppression of Terrorism Agreement, only India ratified it. The complication occurred when there was no consensus on a broad definition ${ }^{20}$ terrorism. As we announced above at the beginning of the subchapter, there are several subjective definitions of this phenomenon and the process of finding the right definition was portrayed as a "jungle of definitions" (Frissen, 2019, p. 7) or as a "search for the Holy Grail" (Ivančík-Nečas, 2019 , p. 59) However, the most

\footnotetext{
${ }^{17}$ Čeka, or otherwise known as the All-Russian Extraordinary Commission for Combating Counter-Revolution and Sabotage at the National Commissioners' Council, was a body serving as a security service in Russia. She became the predecessor of the KGB (State Security Committee).

${ }^{18}$ Black September, Hamas, Hezbollah, the Italian but also the Japanese Red Guards, the French Direct Action, the American Weather Underground, the Irish Liberation Army, the Basque Country and Freedom in Spain, the death squads in Latin America and others (Ivančík-Nečas, 2019).

${ }^{19}$ The IEP is an independent, impartial, non-profit think tank that focuses on world peace as a positive, achievable and tangible measure of human well-being and progress. The IEP achieves its goals by developing new conceptual frameworks for defining peace; providing metrics for measuring peace and others. (IEP, 2020) ${ }^{20}$ The controversial part was the extensive delimitation of the definition, which included all criminal acts directed against the country in order to develop fear against specific citizens of the state (Ivančík-Nečas, 2019).
} 
appropriate definition is the definition adopted by the United Nations in 1999, which was also ratified by the Slovak Republic in 2002, where terrorism is "any other act intended to cause death or serious injury to a civilian or any other person not actively participating in hostilities in the event of armed conflict, if the purpose of the act was, by reason of its nature or context, to intimidate the population or to compel the government or international organization to act or to refrain from any action' (Ministry of Foreign Affairs of the Slovak Republic, 2002, Article 2, paragraph 1 b). Slovakia also accepts, as part of the European integration project, the definition adopted in the document Common Position of the Council of the European Union on the application of special measures to combat terrorism 2001/931/CFSP. clarifies that a terrorist act "means one of the following intentional acts which, by its nature or context, may seriously harm a country or an international organization as defined as a criminal offense under national law ..." (EUR-Lex, 2021, Art. 1 (3).

Documents adopted by international organizations and states always respond to the current situation at the global, regional or national level. That is why 2001 marks the beginning of the massive adoption of resolutions to protect its citizens in the fight against terrorism. The international community has witnessed a brutal terrorist attack on a shopping center in New York and has negated the view that regional problems are spreading rapidly over short distances. In this case, terrorism has no defined geographical boundaries and, with each global challenge, it brings new, more sophisticated methods of intimidation. Today's globalized and interconnected world gives us many opportunities to move forward, but hand in hand with this progress come threats in the online space like cyber attacks. ${ }^{21}$, cyberbullying $^{22}$, cyber espionage ${ }^{23}$, cyberterrorism ${ }^{24}$, cyber jihad ${ }^{25}$ etc. Terrorism has three main effects at its core: the immediate effect of killing or injuring those who are considered a forbidden target; the medium-term effect of intimidation of the larger population, which influences their political behavior; and the overall effect of the disturbance of the overall public policy. (Merl, 2001) The supporters of terrorist acts are mainly terrorist groups, and we will select those that have been most remembered. It is therefore essential that states and regional organizations respond quickly and effectively to new security threats and adapt strategies to protect the environment and lives (Slovak Republic 2021, European Union 2020).

\section{Profiling of selected terrorist groups}

As part of the research question, we will work with two types of terrorist organizations. This subchapter identifies transnational ${ }^{26} \mathrm{Al}$-Qaeda terrorist organizations ${ }^{27}$ (hereinafter referred to as Al Qaeda) and the

\footnotetext{
${ }^{21}$ According to the NATO Cooperative Center of Excellence for Cyber Defense, a cyber attack is considered to be "a cyber operation, whether of the offensive or defensive type, where there is a reasonable presumption that it may cause injury or death or damage or destroy objects". (Fabián- Melková, 2016, p. 25)

${ }^{22}$ UNICEF offers a definition of cyberbullying to protect children online. It is bullying that uses digital technologies. It can take place on social networks, messaging platforms, gaming platforms and mobile phones. It can be about spreading lies or posting embarrassing photos of someone on social networks, sending malicious messages or threats through messages, impersonating someone, or sending bad messages to others on their behalf. Cyberbullying leaves a digital mark as evidence. (UNICEF, 2021)

${ }^{23}$ The Tallin Manual defined cyber espionage "as any act committed in secret or under false pretenses that uses computer technology to gather information with the intention of communicating with the other party." The act must take place in the territory controlled by the party to the conflict. (Tallinn Manual, 2013, p. 193)

${ }^{24}$ This term is considered to be "a criminal offense committed using computer and telecommunications equipment, leading to violence, destruction and / or disruption of services. The aim is to create fear by causing confusion and uncertainty in a given population, in order to influence the government or the population to adapt to a specific political, social or ideological agenda. "(Fabián-Melková, 2016, p. 28) a lesser-known act of leadership under the control of a terrorist organization, as the main problem is the lack of instruments and experts. (Fabián- Melková, 2016)

${ }^{25}$ It is a war organized through the Internet. (Singh- Agarwal, 2017)

${ }^{26}$ According to the extent of terrorist activity, terrorism is being categorized into national, international / transnational and global levels. (Ivančík- Nečas, 2019)

${ }^{27}$ The Arabic word qaeda can be translated as the basis of an activity or base, or alternatively as a prescription or method. Islamic militants have always understood the term in a second sense. In 1987, Abdullah Azzam, a leading ideologue of modern Sunni Muslim radical activists, called on al-qaeda al sulbah (translated as the front line of
} 
Islamic State (hereinafter referred to as IS) and the global network of Salafist-jihadist terrorists with which it is operationally connected and ideologically inspired. These do not state ${ }^{28}$ actors use terrorist tactics to promote religious, political and cultural goals dictated by their ideology. Subsequently, we will show their participation on the European continent through the use of propaganda, a form of influence.

Al Qaeda ${ }^{29}$ has become a complex entity with associated cells around the world since its inception in 1979 in Afghanistan. (Ivančík- Nečas, 2019) Although al Qaeda suffered great damage after September 11, 2001, the professional core of leaders, ideologues and agents remains (McDonald, 2010). Al Qaeda includes trained amateurs directly recruited into the organization, along with others who have participated in training exercises or received funding or weapons support. Their attacks target targets, including Western civilians, embassies and soldiers. They spread fear and intimidation among the public, which acts as a coercive tool and message intensifier. Ideologically, al-Qaeda is considered to be the leader of the jihadist call ${ }^{30}$ and seeks to motivate others who pursue common goals. McDonald draws attention to the fact that many groups have been part of a global network that Al Qaeda has supported since 1990. But a growing number of them, especially those from the Muslim diaspora, have no connection with the organization, but consider it to be source of inspiration (McDonald, 2010). The organization's priority is to build a caliphate (Muslim state) in the Arabian Peninsula, the rise of Islam, expel Western citizens and non-believers, and depose leaders of non-Islamic political regimes. The United States, some European states (especially Great Britain) and supporters of American armed missions (Ivančík-Nečas, 2019) are portrayed as rivals for them.

Al Qaeda is described as part of the "new terrorism". The term refers to a diverse group of actors who use a wide range of terrorist tactics to support the multiple goals of Salafist jihadism. (McDonald, 2010)This group was one of the first terrorist organizations to recognize the importance of the media and use it to its advantage. One of the infamous cases that continues to be reminiscent of the group's cunning is the continuous broadcasting of Osama bin Laden's audio and video tapes in Al Jazeera, which the terrorist group has chosen as its preferred network to spread its message to a wider audience. Al Qaeda's communication strategy consists of a three-tier system in which top leaders exchange messages through password-protected gateways; on Wednesday, other important jihad figures discuss strategy issues in forums that can also be password protected, yet have a slightly more open approach to potential newcomers.

Despite the fact that the group clearly relies on modern technologies and the Internet, it is one of the pioneers in this field and has created a well-known "brand" for itself. However, her current efforts have not been as successful as her rival. In the case of al-Qaeda's branch in the Islamic Maghreb (AQIM) in particular, its use of social media platforms such as Twitter has even been portrayed as a complete failure. Researchers attribute this occurrence to the group's ideological goals, as Al Qaeda tends to target a distant enemy (West) and is more likely to attract passive supporters rather than active willing travelers (EFSAS, 2020).

One of the most popular modern terrorist organizations that we will examine is the Islamic State, also known as the IS in Iraq and Syria (hereinafter referred to as ISIS). It was on June 29, 2014 that ISIS

the strong). It is assumed that men who act independently will set an example for the rest of the Islamic world, thereby encouraging the ummah (global community of believers) against its oppressors. (Burke, 2004)

${ }^{28}$ Non-state terrorism receives support from donors, and pressure is exerted on government officials without giving a reason. These can be unauthorized secret organizations as well as non-governmental groups. (Ivančík- Nečas, 2019)

${ }^{29}$ Until 2011, Osama bin Laden, the leader of the Sounni Islamic terrorist network, was shot dead by American troops. (Clarke- Lister, 2019)

${ }^{30}$ The English original is jihad. Jihad (Arabic meaning "fight" or "effort"). INIslamit means a meritorious struggle or effort. The exact meaning of the term jihad depends on the context. In the West, it has often been mistaken for a "holy war." Jihad, especially in religious andethicalThe area primarily refers to the human struggle to promote what is right and what is wrong.It is an extremist version of Islamism. Only fighting can restore the caliphate. (Britannica, 2020) 
announced that it had established a caliphate.ISIS has undoubtedly established itself as the greatest pioneer in the extensive use of virtual space for the purpose of conducting its operations and consolidating its influence and control. Since its inception, members of the extremist organization have begun to use online platforms to promote their ideology and to support others, especially young individuals deprived of their rights, to support their affairs, travel to the Middle East and participate in terrorist acts. (EFSAS, 2020) The caliphate's statement was accompanied by a wave of propaganda in which ISIS called on all Muslims in the world to swear allegiance to the self-proclaimed caliph Abu Bakr Baghdad and settle in territory under his control (BBC, 2019). Around the announcement of the Caliphate, the group also launched its media campaign documenting the conquest of Mosul. Following the announcement, ISIS released a series of media editions, including an audio recording of Abu Bakr al Baghdadi announcing the caliphate, videos entitled Breaking the Borders and The End of Sykes Picot, and the first issue of its Dabiq magazine (Leppink, 2017). ISIS is often described as more dangerous than $\mathrm{Al}$ Qaeda in terms of the threat it poses to many countries in the world (Arosoaie, 2015). Although the strength, attractiveness and longevity of the group have often been intensively discussed, ISIS remains at the forefront of the jihadist movement. His struggle focuses on building and expanding a selfproclaimed entity (General Intelligence and Security Service, 2016). Fishman's words state that the ISIS territory is depicted as a peaceful coexistence with strict rules of fundamentalist interpretation of its religion (Fishman, 2016). A bizarre element that is being promoted is that in this idyllic world of its propaganda, every home where there is enough good food, waste is regularly collected, and the availability of excellent medical care is regularly collected. ISIS also likes to give the impression that it serves the Syrian and Iraqi people, and that any violence it uses in doing so is purely defensive (General Intelligence and Security Service, 2016). This fact will be a relevant element for us in the study of recruitment narratives (Leppink, 2017). ISIS shares the same ideology as Al Qaeda ${ }^{31}$ (Arosoaie, 2015).

It is important to note that the approach to violence is also different for both groups. Al Qaeda, especially Bin Laden's initial communication, depicted defensive jihad, a battle to support and protect the ummah or the global Muslim community from the onslaught of the West. While there must have been unforgivable violence and attacks on civilians, there have also been some attempts in rhetoric to justify or even limit the consequences. In contrast, ISIS seems to enjoy its savagery, and hostile treatment and killing of hostages seems to attract other new members, even if it disgusts the world (Fink-Sugg, 2015). Monaci (2017) identifies three key assets of the ISIS media strategy based on its analysis of the online magazine IS Dabiq - synergistic storytelling, imaginary world creation and semantic launch .. (Monaci, 2017).Propaganda production has been increasing since the announcement. The exact number is difficult to measure due to the large amount that is protected on the site by authorized access. These publications are on the ISIS website and in journals (see subchapter 2.3). They are available in a variety of languages including Arabic, English, French, Turkish, Russian and German. The increase, together with the first issue of its English magazine Dabiq, suggests that ISIS was willing to make greater efforts to recruit foreign fighters (see Chapter 3). The propaganda is disseminated by various local media departments, which are responsible for different regions and types of propaganda. Publications are often professional and all seem to be highly organized (Leppink, 2017).

The next research group we identify in the research are jihadist Salafists. Salafista ${ }^{32}$ advocates a return to tradition (Habeck, 2019). Jihad refers to the internal spiritual struggle that a Muslim undergoes in the conduct of a godly life, which can also be used as a war act to defend Islam. (Sedgwick, 2015) It is this idea that has taken on a special shape in recent years. This global network was established around 1990 when it was adopted by Al Qaeda. The technical definition of this matter stems from the captured

\footnotetext{
${ }^{31}$ This is most evident in relation to key Islamic concepts, namely "al-wala, wa al-bara", takfir and jihad. The concept of al-wala "wa al-bara", translated as loyalty and rejection. It aims to strengthen solidarity between individuals in a particular group and at the same time to make a clear distinction between members of another group. The concept basically tends to distance itself from individuals on the basis of whether they are good or bad. Jihads-Salafi can then excommunicate individuals through takfir (excommunication) and label them as a suitcase (unbeliever), which then legalizes the shedding of their blood. (Arosoaie, 2015)

${ }^{32}$ In practice, the Salafist argues that Muslims should only rely onQuran (a religious work on Islam), sunnu (part of Islamic law, includes the traditions and deeds of the Prophet Muhammad) and the consensus of salaries, ignoring the rest of Islamic teaching. (Habeck, 2019)
} 
primary documents and the jihadist discourse over the Internet, which has the same message. (Spencer, 2018) Jihadist Salafists initially believe that the ummah needs to be defended against blasphemous regimes in the Muslim world. By not rejecting modernity and implementing sharia (Islamic law), these regimes have diverted Muslims from their true path. Leading the jihad with the sword against these regimes and dismantling their social and political order will pave the way for the restoration of the caliphate. Proponents of this trend believe that other countries are involved in the global conspiracy against Islam as a religion, culture and way of life (McDonald, 2010). Its enemies are the United States along with other "Christian crusader" countries. ${ }^{33}$, their allies, democracy, sewing and Sufism as Islamic mysticism that must be destroyed. Salafiji jihadists seek to take over religion and lead it to extremist diversion (Habeck, 2019).

Jihadist Salafism is also famous for its global propaganda. Since the 1990s, ideologues and terrorist organizations have skillfully used the Internet to spread this interpretation of Islam among younger generations of Muslims, but not only among them, many of whom attract attacks on Western ideologies. Jihadist works are readily available in several languages ${ }^{33}$ around the world. Followers include mainly al Qaeda leaders, religious scientists, strategists, affiliated and unrelated cells, and thousands of supporters. Al Qaeda is trying to achieve its goals with a pen and a sword. It is a source of violent jihad (led by terrorist attacks) and ideology, which inspires the global movement, especially in the online space (McDonald, 2010).

The terrorist groups just mentioned also occur in the European Union. The jihadist background in Europe consists of loosely connected networks. Extremist environments in Europe, both physical networks and online communities, provide space for social and religious activities in which individuals can radicalize. In the online space, we have recorded sites such as Sharia4UK, Sharia4Belgium, etc. Between 2017 and 2019 , there was a slight decrease in attempts at terrorist attacks. Based on data from the European Union (hereinafter referred to as the EU) between 2017 and 2019, we identify a reduction in attacks from 205 through 129 to 119 (453 in total). Of the total number (78) of jihad-related incidents in the EU, their quantity decreased slightly (21 in 2019 and 24 in 2018), but jihadism continued to spread geographically. It is remarkable that for the second year in a row the number of failed (14) jihadist conspiracies significantly exceeds the number of completed (3) and unsuccessful (4) jihadist attacks. (Europol, 2020) However, in 2018, all but one of the seven completed or unsuccessful attacks were incidents committed by individuals acting alone, while most failed (16) conspiracies involved more suspects (Europol, 2019). The potential of ethnic-nationalist and separatist groups in particular is becoming a matter of concern while most of the failed (16) conspiracies involved more suspects (Europol, 2019). The potential of ethnic-nationalist and separatist groups in particular is becoming a matter of concern while most of the failed (16) conspiracies involved more suspects (Europol, 2019). The potential of ethnic-nationalist and separatist groups in particular is becoming a matter of concern ${ }^{34}$, where out of 453 , more than 137 incidents are attributed to this group in 2017. The following two years of attacks by this group dropped by 80 incidents.

The majority of attackers (almost 70\%) were between the ages of 20 and 28. The youngest offenders were 16 and 17 years old. Although the majority of jihadist terrorists were men (85\%), the eight perpetrators were women. Map 1 shows the quantity of attacks (red) and arrests (blue) in EU countries. They were arrested last year ${ }^{35}$ more than 1004 attackers, where Belgium, France, Italy, Spain and the

\footnotetext{
${ }^{33}$ The English original is Christian crusader (McDonald, 2012, p. 10)

${ }^{34}$ Ethno-nationalist and separatist terrorist groups are motivated by nationalism, ethnic origin or even religion. Separatist groups seek to divide the state from a larger country or annex territory from one country to another. Left-wing or right-wing ideological elements are not uncommon in these types of groups. The Republic of Ireland (IRA) and the Basque ETA fall into this category. (Europol, 2020)

${ }^{35}$ The most common crimes leading to arrest were, regardless of gender, for membership in a terrorist group and participation in a terrorist conspiracy, aiding and abetting and financing terrorism. 3057 jihadist suspects arrested since 2015 (Europol, 2020)
} 
United Kingdom ${ }^{36}$ captured the largest number ${ }^{37}$ In more than $70 \%$ of arrests for which citizenship was reported to Europol (242 out of 335), the country of arrest and the citizenship of the offender were the same (Europol, 2020). This group, which organizes terrorist attacks in Europe, is mainly linked through networks. They are rooted in the wider Muslim extremist environment, which can act as a means of leading terrorist attacks. The networks are mostly domestic and without organizational ties to terrorist groups such as Al Qaeda or the so-called Islamic State. In addition, it has been shown that some individuals or small groups become radicalized mainly on the Internet, without being part of wider networks (Europol, 2020). Online communication has exponentially increased the ability of terrorists and violent extremists to communicate across borders.

\section{Terrorism and the Internet as a dangerous symbiosis}

The threat of terrorist acts is currently one of the most debated topics, as it is a very important media topic and easily reaches the print media and the Internet. Using the simplest algorithm ${ }^{38}$ Searching by simply typing the word "terrorism" into a search engine will generate 130,000,000 hits ${ }^{39}$ (Lang, 2018).

The last two decades have shown a trend towards a beneficial relationship between terrorist organizations and the media (Rohner-Frey 2007). Like some notable terrorist attacks in Europe ${ }^{40}$ or on other continents, terrorist architects use the Internet for their operational efficiency, information gathering, recruitment, fundraising, and propaganda scheme. (Bilgen, 2012) The terrorist use of online platforms is not new. Following the events of $9 / 11$ and the ensuing counter-terrorism campaign, a large number of terrorist groups moved into cyberspace and set up thousands of websites to promote their news and activities (Weimann, 2014).

The Internet ${ }^{41}$ from its innocent beginnings exploded as the primary source of global communication. There are currently more than 5 trillion users online on the Internet. These figures represent $65 \%$ of the world population that is connected - the data are from 2020 (Internet world stats, 2020). It seems very likely that the greatest benefit of the Internet is social networks as a communication tool also used by terrorist organizations. The Internet has prepared a living ground for terrorists but also for the media. In return, this receives a great deal of public attention, which is essential for their existence and the benefits of a large audience. In short, just as terrorism must be communicated in order to be effective, the media must cover incidents in such a way that to benefit from the public's eagerness to obtain information on terrorist attacks (Seib-Janbek 2011). In Frissen's research article, we find that "terrorism is communication"42 (Frissen, 2019, p. 72). In this context, Jenkins says that terrorists "want many people to watch and not many people dead" (Jenkins, 1985, p. 4). Terrorism has a serious mass psychological aspect. It needs to effectively maintain an atmosphere of heightened fear, insecurity and psychological excitement, as this gives terrorists the power they want. Therefore, it is often said that terrorism is a form of sophisticated psychological warfare (Horgan, 2005), in which the impact goes beyond the victims themselves and the violence of the immediate event. Therefore, in this spirit, it is argued that terrorism is a tactical communication tool (Frissen, 2019).

\footnotetext{
${ }^{36}$ However, the United Kingdom is no longer a member of the EU until 31 January 2020. The UK applied Article 50 of the Treaty on European Union, which it announced on 29 March 2017, based on the results of the 2016 referendum. (MFA, 2021)

${ }^{37}$ There are 86 arrests reported by Belgium and 281 arrests reported by the United Kingdom, but does not include 147 other arrests in Northern Ireland. (Europol, 2020)

${ }^{38}$ The Oxford Advanced Learner's Dictionary defines an algorithm as a set of rules that must be followed to solve a particular problem (Oxford Learner's Dictionary, 2021).

${ }^{39}$ Updated record in March 2021.

${ }^{40}$ Based on information from Europol, vIn 2019, there were 119 terrorist attempts in Europe, counting those that were successful and those that failed or were thwarted. Of these, 21 are attributed to jihadist terrorism. For example, the attack in Lyon, Paris, London and Utrecht. (European Parliament, 2020)

${ }^{41}$ The Internet was originally developed by the US Department of Defense in the early 1960s as a means of exchanging information for scientists and academics. Until the mid-1990s, the communication medium was maintained by the National Science Foundation.

${ }^{42}$ English form of expression terrorism is communication.
} 


\section{Conclusion}

How do terrorist organizations benefit from the progress of social networks? Social media has brought benefits in many different areas of operation, and has therefore become a very beneficial modern benefit for terrorist organizations (Bertram, 2016). Even in the publications of esteemed scientists on terrorism and radicalization, there are surprisingly informal and uncritical claims about the functions and effects of the Internet. For example, in a famous article by Alex P. Schmid in 2013, he stated that "there is no doubt that the low-cost, easy-to-access, high-speed, anonymous, decentralized, large-scale, global connectivity, and weak or absent Internet has played an important role in disseminating radical messages. The question is not whether the Internet has an impact. We know for sure that it has a large and diverse impact on many of its users" (Schmid, 2013, pp. 33-34). New communication technologies are relatively inexpensive and accessible, creating highly interactive platforms through which individuals and communities share, co-create, discuss and modify content (Weimann, 2014). Online communication has exponentially increased the ability of terrorists and violent extremists to communicate across borders ${ }^{43}$ (Europol, 2020). There are several reasons why terrorists use social networks. First, these channels are by far the most popular with their equally intended audience, allowing terrorist organizations to be part of the mainstream. Second, social media channels are user-friendly and reliable. Finally, social networks allow terrorists to reach their target audience and practically knock on their door (Weimann, 2014). Commercial platforms tend to offer a wider reach than dedicated areas created by the terrorists themselves, but are more likely to be monitored by their owners, most of whom oppose the hosting of terrorist content (Europol, 2020). The Internet has become a major domain for terrorist activities, offering more opportunities and a considerable amount of material available.

The paper was published within the project VEGA no. 1/0320/21 "The role of universities in building the knowledge economy".

\section{Literature}

AROSOAIE, A. (2015). Doctrinal Differences between ISIS and Al Qaeda: An Account of Ideologues. In International Center for Political Violence and Terrorism Research. [online]. 2015, vol. 7, no. 7, p. 31-37. [cit. 2021-24-02]. Available online: 〈https://www.jstor.org/stable/pdf/26351374.pdf〉.

BARIČIČOVÁ, L'.- IVANČÍK, R. (2019). Terrorism - one of the most serious threats to European security in the 21 st century. In Current problems resonating in Europe (legal-security aspects). Bratislava: Akadémia Policajného zboru v Bratislave, 2019. ISBN 978-80-8054-826-1, p. 19-31.

BURKE, J. (2004. Al Qaeda. In Foreign Policy. [Online]. 2004, no. 142, pp. 18-26. [Cited 2021-2102]. Available online: <www.jstor.org / stable / 4147572> . ISSN: 00157228

CLARKE, CP-LISTER, CH. (2019). Al Qaeda is ready to attack you again. In RAND [online]. 2019. [cit. 2021-22-02]. Available online: <https://www.rand.org/blog/2019/09/al-qaeda-is-ready-to-attackyou-again.html>.

DEAN, G. (2014). Neurocognitive Risk Assessment for the Early Detection of Violent Extremists. Cham: Springer, 2014. 112 p. ISBN 978-3-319-06719-3

DICTIONARY. (2021. Terrorism. [Online]. 2021. [cited 2021-19-02]. Available online: <https://www.dictionary.com/browse/terrorism>.

EUROPOL. (2018). European Union terrorism situation and trend report. [online]. 2018. [cit. 2021-2602]. Available online: <https://www.europol.europa.eu/activities-services/main-reports/european-

\footnotetext{
${ }^{43}$ Current terrorist groups have communication experts among their members and work with sophisticated computers and video recording and editing equipment, as well as hiring media experts. For example, in October 2005, Asharq al-Awsat, a London-based pan-Arab daily, reported that al-Qaeda had placed an "we are looking for help" advertisement on a website describing jobs in the communications sector. (Shuaibi, 2015)
} 
union-terrorism-situation-and-trend-report-2018-tesat-2018>. ISBN 978-92-95200-91-3. DOI 10.2813 / 00041. QL-AJ-18-001-EN-N

EUROPOL. (2019). European Union terrorism situation and trend report. [online]. 2019. [cit. 2021-2602]. Available online: <https://www.europol.europa.eu/activities-services/main-reports/terrorismsituation-and-trend-report-2019-te-sat>. ISBN 978-92-95209-76-3. DOI 10.2813 / 788404

EUROPOL. (2020). European Union terrorism situation and trend report 2020.[online]. 2018[cit. 2021-1904]. Available online: <https://www.europol.europa.eu/activities-services/main-reports/europeanunion-terrorism-situation-and-trend-report-te-sat-2020>.

FISHMAN, BH (2016). The Master Plan: ISIS, al-Qaeda, and the Jihadi Strategy for Final Victory. New Haven: Yale University Press, 2016. 354 p.ISBN 978-0-300-22149-7

FRISSEN, T. (2016). (Hard) wired for terror: unraveling the mediatized roots and routes of radicalization: dizertačná práca. Leuven: KU, 2019. 381 p.

FRISSEN, T. (2021). Internet, the great radicalizer? Exploring relationships between seeking for online extremist materials and cognitive radicalization in young adults: výzkumná práca. Leuven, KU, 2021. $13 \mathrm{p}$.

HABECK, M. (2019). How to Identify Jihadi-Salafists Through Their Ideology, Practices, and Methodology [online]. 2019. [cit. 2021-24-02]. Available online: <https://westminsterinstitute.org/events/how-to-identify-jihadi-salafists-through-their-ideology-practices-and-

methodology/>.

HORGAN, J. (2005). Psychology of Terrorism. New York: Routledge. 2005. 206 p. ISBN 9780415698023.

HORGAN J.- BRADDOCK, K. (2010 (. Rehabilitating the terrorists?: Challenges in assessing the effectiveness of de-radicalization programs. In Terrorism and Political Violence. 2010, Vol. 22, no. 2 p. 267-291. [ cit. 2021-10-03] Available on the Internet: <https://doi.org/10.1080/09546551003594748>.

HORGAN, J. (2005 (. Psychology of Terrorism. New York: Routledge. 2005. 206 pp. ISBN 9780415698023.

IVANČÍK, R.- NEČAS, P. (2019 (. Terrorism: global security threat. Ostrava: KEY Publishing, 2019. 163 pp. ISBN 978-80-7418-319-5.

EUROPOL. (2018). European Union terrorism situation and trend report. [online]. 2018. [cit. 2021-2602]. Available online: <https://www.europol.europa.eu/activities-services/main-reports/europeanunion-terrorism-situation-and-trend-report-2018-tesat-2018>. ISBN 978-92-95200-91-3. DOI 10.2813 / 00041. QL-AJ-18-001-EN-N

EUROPOL. (2019). European Union terrorism situation and trend report. [online]. 2019. [cit. 2021-2602]. Available online: <https://www.europol.europa.eu/activities-services/main-reports/terrorismsituation-and-trend-report-2019-te-sat>. ISBN 978-92-95209-76-3. DOI 10.2813 / 788404

EUROPOL. (2020). European Union terrorism situation and trend report 2020.[online]. 2018[cit. 2021-1904]. Available online: <https://www.europol.europa.eu/activities-services/main-reports/europeanunion-terrorism-situation-and-trend-report-te-sat-2020>.

JENKINS, BM (2017). Recruitment Propaganda of the Islamic State: Recruiting Narratives in the Islamic State's Propaganda: bakalárska práca. Utrecht: Universiteit Utrecht, 2017. p. 29.

MONACI, S. (2017). Explaining the Islamic State's Online Media Strategy: A Transmedia Approach. In International Journal of Communication [online]. 2017. [cit. 2021-24-02]. Available online: <https://www.researchgate.net/publication/324774136_MONACI_SARA_2017_Explaining_the_Isla mic_State's_Online_Media_Strategy_A_Transmedia_Approach_INTERNATIONAL_JOURNAL_OF _COMMUNICATION>. 
MONACI, S. (2017). Explaining the Islamic State's Online Media Strategy: A Transmedia Approach. In INTERNATIONAL JOURNAL OF COMMUNICATION. [online]. 2017 [cit. 2021-25-04]. Available online: <https://www.researchgate.net/publication/324774136_MONACI_SARA_2017_Explaining_the_Isla mic_State's_Online_Media_Strategy_A_Transmedia_Approach_INTERNATIONAL_JOURNAL_OF _COMMUNICATION>.

MCDONALD, LZ (2012). Engaging Young People within a Counter-Terrorism Context. In: Spalek B.[online]. 2012 Available on the Internet: Available on the Internet: <http://icct.nl/app/uploads/2019/03/Marone-Vidino-Italys-Foreign-Fighters-March2019.pdf>.

MERL, SR 2001. Internet Communication Standards for the 21st Century: International Terrorism Must Force the US to Adopt "Carnivore" and New Electronic Surveillance Standards. In Brooklyn Journal of International Law. [online]. 2001. vol. 27, no. 1, p. 246- 261. [cit. 2021-20-02]. Available online: <https://core.ac.uk/download/pdf/228605045.pdf>.

ROHNER, D.- FREY, B. (2007). Blood and Ink! The Common-Interest-Game Between Terrorists and the Media. In Researchgate [online]. 2007. [cit. 2021-01-03]. Available online: <https://www.researchgate.net/publication/303547342_Blood_and_Ink_The_Common-InterestGame_Between_Terrorists_and_the_Media>. DOI:10.2139/ssrn.900353.

SEDGWICK, M. (2015). Jihadism, Narrow and Wide: The Dangers of Loose Use of an Important Term. In Terrorism Research Initiative [online]. 2015, vol. 9, no. 2, p. 34-41. [cit. 2021-25-02]. Available online: <https://www.jstor.org/stable/26297358\#metadata_info_tab_contents>.

SEIB, P.- JANBEK, DM (2011). Global terrorism and New Media: The post- Al Qaeda Generation. New York: Routledge, 2011. 156 p. ISBN 9780415779623.

SEIB, P.- JANBEK, DM (2011). Global Terrorism and New Media: The post-Al Qaeda generation. [online]. 2011. [cit. 2021-16-04]. Available online: <https://www.researchgate.net/publication/291943215_Global_Terrorism_and_New_Media_The_Post -Al_Qaeda_Generation>. ISBN 9780203845370. DOI:10.4324 / 9780203845370.

SINGH, HP- AGARWAL, A. (2017). Role of Social Media for Propagating and Countering Terrorism. In Mumukshu Journal of Humanities. Saudi Arabia: University of Hail. 2017. p. 9-11. ISSN 0976-5085.

SINGH, J. - KERR, P.- HAMBURGER, E. (2016). Media and information literacy: reinforcing human rights, countering radicalization and extremism. Paris: United Nations Educational, Scientific and Cultural organization, 2016. 324 p. ISBN 978-92-3-100177-2.

SPENCER, R. (2018). The history of Jihad. [online]. 2018. [cit. 2021-24-02]. Available online: <https://westminster-institute.org/events/robert-spencer/>.

WEIMANN, G. (2014). New Terriorism and New Media. [online]. Washington, DC: Commons Lab of the Woodrow Wilson International Center for Scholars, 2014. 20 p. [cit. 2021-01-03]. Available online: $<$ https://preventviolentextremism.info/sites/default/files/New\%20Terrorism\%20and\%20New\%20Med ia.pdf $>$. 
DOI: 10.36682/SSS_2021_10

\author{
Mgr. Jitka Kosáčková \\ Department of Health Sciences and Population Department of Health Care and Population \\ Protection Protection \\ Faculty of Biomedical Engineering Czech Technical Faculty of Biomedical Engineering Czech Technical \\ University in Prague University in Prague \\ $\triangle$ U.S. Sitná 3105, Kladno, Czech Republic \\ Email:jitka.kosackova@gmail.com
}

Mgr. Renata Havrankova, Ph.D.

\author{
Department of Health Sciences and Population Department of Health Care and Population \\ Protection Protection \\ Faculty of Biomedical Engineering Czech Technical Faculty of Biomedical Engineering Czech Technical \\ University in Prague University in Prague \\ $\triangle$ U.S. Sitná 3105, Kladno, Czech Republic \\ Email: renata.havrankova@fbmi.cvut.cz.
}

\author{
Department of Radiology, Toxicology and Population Institute of Radiology, Toxicology and Civil \\ Protection Protection \\ Faculty of Health and Social Studies Faculty of Health and Social Sciences \\ University of South Bohemia in České Budějovice University of South Bohemia in České Budějovice \\ $\varangle$ J. Boreckého, 370 11, České Budějovice, Czech Republic
}

\begin{abstract}
Annotation
Protection of medical facilities that are easily accessible public places with a quite high level of luctuation of people and low level of security against violent attacks is a current issue. The common goal of these attacks is to purposely injure people present in the facilities, so-called "soft targets". Easy accessibility leads to the fact that these places can be entered by a dangerous person who might not be adequately controlled. Medical staff is often attacked by aggressive individuals, including a possible attack by an armed attacker, so-called "active shooter". In addition to the threat or loss lives of staff or patients, also a property can be threatened. In these days, great emphasis has been placed on medical facilities preparedness regarding to these incidents so that the staff would possibly be able to quickly and adequately react. The work focuses on the issue of aggressive behavior towards medical staff. Above all, emphasis must be placed on readiness of employees in order of their ability of adequate response. The aim is to make up a solution model for particular security incidents and to plan other necessary steps towards the overall security level improvement within the protection of medical facilities as soft targets.
\end{abstract}

Key words: medical facilities, soft target, security, protection possibilities, aggressor

\title{
Introduction
}

In general, soft targets can be defined as places with a high concentration of population and at the same time a low level of security against violent attacks. The Terminological Dictionary of the Ministry of the Interior of the Czech Republic (MV ČR, 2016) defines soft targets as publicly frequented places, easily attackable objects or places of a non-military nature that are not permanently guarded by armed forces or otherwise, or are not guarded at all. These places and buildings are characterized in particular by a permanent or temporary high concentration of people or a significant part of the state's infrastructure, the disruption of which has a negative impact on the functioning of the state system and thus on society. 


\section{Soft target protection concept}

Both closed spaces and open spaces to which the public has free access can be included in the category of soft targets. A common feature is the high concentration of people moving in a given place, which is also an attractive target for entities committing violent acts or terrorist attacks. If such an attack on a soft target is carried out, a high number of victims can easily cause health and life, which results in the promotion of their own goals, attracting the attention of the general public and media and at the same time has a significant impact on the psyche of the population (MV ČR, 2017).

Among the soft goals according to the Concept of protection of soft goals for the years 2017-2020 (2017) we generally rank:

- bars, clubs, discos, restaurants and hotels;

- cinemas, theaters, concert halls, entertainment centers;

- community centers,

- cultural, sporting, religious and other events;

- religious monuments and places of worship;

- shopping malls, markets and shopping complexes;

- hospital;

- parks and squares;

- political rallies, parades, demonstrations;

- sports halls and stadiums;

- school facilities, dormitories, canteens, libraries;

- tourist monuments and attractions, museums, galleries;

- public institutions;

- major transport hubs, train and bus stations, airport terminals;

- other symbolically significant places or events;

- and more.

In order to create protection of soft targets, it is always necessary to take into account several basic principles that should lead to the emergence of full-fledged protection (Ministry of the Interior of the Czech Republic, 2017):

- The first principle of the approach to protection is the realization that the security of soft targets is a matter for the actors concerned, not just the state. Therefore, the basic components of the integrated rescue system and the Ministry of the Interior of the Czech Republic, as well as other relevant ministries, central administrative authorities, local government, but also owners or operators of soft targets must participate in comprehensive protection.

- The second principle is a proactive approach to the protection of soft targets. It is an active approach on the part of the state and the soft targets in question. It is necessary to realize that although these may be isolated violent attacks, it is necessary to prepare for them in the long term and systematically. It is impossible to only wait and react until these attacks occur. This is usually a very serious situation. It is therefore appropriate for the initiative to be visible primarily on the soft target side. Only the cooperation of the soft target and the state can ensure a higher degree of security.

- The third principle is synergy. To successfully solve a problem, mutual knowledge and cooperation between the soft target, its personnel and the relevant security forces is required. Whether it is any serious violent incident with different variability of motivation and type, usually of short duration, close cooperation is necessary. Furthermore, cooperation between the soft target and entities located in the immediate vicinity is important. It is crucial that there is mutual familiarity and functioning communication channels between soft targets and the relevant components.

- The last fourth principle is the use of practical experience. Only investment in material equipment and technology does not have to increase the durability and safety of a soft target. Disorganization and incoordination are often central issues. Therefore, for effective protection, the correct setting of communication processes, organization and coordination of the activities of persons, ie personnel, their preparation and determination of the division of labor in the event of emergencies, etc. is necessary. 
In this context, the state develops activities related to the protection of soft targets. At the moment, it offers soft targets several ways to strengthen its security and envisages further steps in the future. These are (MV-Ǧ̌ HZS ČR, 2019):

- ongoing methodological activities (methodological publications that can be freely downloaded from the website of the Ministry of the Interior of the Czech Republic - Fundamentals of Soft Target Protection, Threat Assessment, Standardization of Security Plans) and seminars for the professional and lay public;

- assistance in creating security (personal consultations of members of the Police of the Czech Republic or the Ministry of the Interior of the Czech Republic, establishment of a police telephone line for soft targets, etc.) and training of police specialists for soft targets;

- increasing the preparedness of all components of the integrated rescue system for possible intervention in a terrorist attack;

- unified management and unification of the procedure of all stakeholders (including, for example, the introduction of sending SMS alerts to citizens);

- the establishment of subsidy programs to support the protection of soft targets (the programs in the first period focus on non-investment actions, which should be used in particular for risk assessment, creation of security plans and procedures, training, exercises and exercises);

- systems for actively informing soft targets through an alert system (SMS, mobile applications); a similar system has been introduced by the Ministries of the Interior in France and Spain, and has also been operating in Israel for a long time.

\section{Medical devices as a soft target}

Medical facilities are publicly accessible places with a higher incidence of people and a low level of security against violent attacks. Their easy accessibility means that a really dangerous person can come to these areas without the possibility of adequate control. In addition to physical attacks, which can occur without a weapon or with a weapon, it can be arson, an attack with an explosive substance or booby trap, an attack on infrastructure or a dangerous threat (Nemocnice České Budějovice, as, 2020). In addition to endangering or destroying the human lives of employees or patients, property may also be endangered. Recently, therefore, great emphasis has been placed on the readiness of medical facilities for these situations, so that employees can respond quickly and adequately.

The legal environment for the protection of soft targets in healthcare facilities in the Czech Republic is currently practically identical to the legal environment for all natural and legal persons and other organizations that need to secure themselves against serious infringements. So far, however, there is no specific standard that specifically addresses the protection of soft targets of these devices. The essence of effective measures to increase the security of soft targets does not lie in legal institutes or their use, but in factual preventive and reactive measures of an organizational, security, rescue or communication nature. When assessing the threat, it is necessary to clarify what I want to protect, against whom I want to protect my values and how these individual sources of threats attack (Kalvach, 2016).

There are no accurate statistics and research on assault and violence in hospitals in the Czech Republic. One of the reasons for the absence of numbers is also the non-reporting of adverse events by healthcare professionals. Non-physicians are most at risk in healthcare facilities, as they are the first to come into contact with a patient and are more likely to be in contact with patients in the ward than in doctors. Aggression aimed at staff, which has an emotional impact on them, can result in problems in their personal and professional lives. Employers often, for fear of gaining a bad reputation for their facilities, are reluctant to deal with emergencies, including violence. For many employees, this may also be a reason to leave health care. Incidents cannot always be completely prevented, but it is important to focus on the prevention of violence, to protect employees as much as possible with the help of a security agency, to introduce prevention programs in the hospital, install security cameras, take strategic steps to reduce violence and enable employees to train in self-defense. It is important to report and analyze adverse events related to employee attacks and threats. Provide psychological help or intervention to health professionals. 
Unfortunately, healthcare professionals themselves are responsible for some of the aggressive manifestations of patients due to inappropriate, unprofessional behavior, incorrect verbal and nonverbal communication, poor ordering system (long waiting for examination), increased bureaucracy and more. It is therefore necessary to focus, within the training of employees, on appropriate communication, to teach health professionals with an aggressive patient, or to communicate professionally with his family not only verbally, to train them how to manage tense situations and how to face danger. Healthcare professionals must have procedures in place to prevent crisis situations and who to contact in the event of a threat.

\section{Violence in health care and its types}

Violence in health care has been defined by many authors of professional publications. In general, the most well-known is the broad definition of violence as the use of force against someone to overcome their resistance. The Health Services Advisory defined violence as "any incident in which an employee is verbally abused, threatened or attacked by a patient or relative in occupational circumstances" (Haškovcová, 2004, p. 13). In healthcare, contact with aggressive patients and their relatives cannot be avoided. When they examined the incidence of violence in various professions in the United Kingdom, they found that health professionals were three to four times more vulnerable than other professions (Háva, 2004).

Healthcare professionals working under great pressure, under constant stress, in an atmosphere of fear, insecurity and anger, really cannot do their best. Negative effects on the health care organization can be manifested by the increasing absence of employees at work, deteriorating employment relationships, declining motivation, reduced quality of care provided, staff turnover and difficulties in recruiting new employees. In medical facilities, we can theoretically encounter all kinds of violence that we generally know. These include physical violence, verbal assault, sexual harassment, racial humiliation and mobbing. Repeated and, in the long run, offensive behavior manifested by invectives, cruel or malicious attempts to humiliate or ridicule an individual or a group of employees (Háva, 2004).

Violent behavior always takes place against a certain background of too high or socially unacceptable demands and expectations, which cannot be met in the normal way. R. Montau mentions five motivations for the emergence of aggression with subsequent violence (Poněšický, 2004):

1. Tension caused by frustration, increasing stress without the possibility of a solution.

2. Violence that is an expression of resentment and protest - chronic frustration.

3. Violence as a means of gaining self-esteem, self-confidence, pride, as the only way to show courage, to prove oneself.

4. Violence as a motive for social inclusion and group status.

5. Trying to actively achieve something, thus being convinced of the influence and effect of one's own behavior.

In medical facilities as elsewhere, we can encounter two types of rapists. Most aggressors belong to the category of emotionally reactive type of rapist. There is a characteristic fury, easy flammability or explosiveness and a rapid transition to an impulsive reaction with a small internal or external stimulus. Aggression arises here because such individuals are easily provoked because they are emotionally irritable. And the instrumental type of rapist exercises his aggression if he consciously wants to satisfy his needs, to achieve some goal such as gaining power, status and money. The rapist is convinced that aggression will pay off. He acts coldly and deliberately, tactically and thoughtfully. Planning aggressive behavior and choosing aggressive means to achieve a goal or decision to commit aggressive acts are among the basic equipment of an instrumental aggressor. At the same time, recognizing the possible consequences of aggression can be a regulatory mechanism. Cognition is therefore an integral part of aggressive behavior. If we want to avoid being attacked by an aggressive client, we should be vigilant and try to assess the risks of being attacked. The risk of an aggressive attack can be determined at first sight without knowing anything about it. It is enough to read carefully the non-verbal signals of aggression (Novák, 1996). 
The principles of how to behave and deal with an aggressive client must be known and followed, as they protect healthcare professionals, help the client to calm down and know the motives for his inappropriate behavior. If the aggressive client cannot be calmed down and we want to prevent injury to health and destruction of property, all that remains is to use means of restricting the movement of the aggressive client. Means of restricting movement (restrictive means) include (Balická, 2005):

- physical means - hand grips (physical intervention);

- mechanical means - courts, stirrups, belts, clamping jackets, isolation rooms;

- chemical agents - sedatives, neuroleptics.

We consider physical intervention to be any method of responding to problem behavior that involves the use of some degree of direct physical force to restrict movement or mobility. The use of physical intervention is appropriate if we want to prevent injury (Balická, 2005):

1. the client himself;

2. nursing staff;

3. other clients;

4. and to prevent the destruction of property.

Physical interventions are used in the current situation of endangering the health or life of the client or another natural person and are one of the extreme measures. Stress reduction for clients must be achieved primarily through prevention, access, communication, environmental modification, risk prevention. The correctness of physical intervention is increased by thorough training, rehearsal and requires the necessary number of employees. Each intervention must be documented after completion (Balická, 2005).

\section{Prevention of violence}

Violence prevention takes place on two levels. At the first level, the aim is to prevent or at least reduce the occurrence of violent acts. At the second level, if a violent act occurs, support must be provided for the person who experienced the event. This support should aim to minimize the harmful consequences of the incident for the victim. In this context, it is important not to leave the victim alone immediately after the incident and to provide psychological support immediately after the incident and later if posttraumatic stress disorder occurs. Provide assistance with administrative and legal steps related to the incident. Each event should be investigated, from which consequences should be drawn if we want to improve preventive measures and learn lessons for the future (Háva, 2004).

The aim is prevention through hazard identification, risk assessment and the adoption of preventive measures, taking into account the working environment where the work takes place. Important preventive measures in health care facilities include (Háva, 2004):

- staff training - health professionals should be able to recognize the initial signs of aggression and impending violence, correctly assess the situation, be able to defend themselves, be able to communicate, be able to prevent conflicts, know how to manage stress, know the procedures designed to protect employees;

- ensuring the environment - sufficient lighting of entrances, stairs and waiting rooms, a pleasant and soothing environment in waiting rooms, comfortable seats and armchairs, providing information on delays;

- installation of security features - take into account physical security measures, such as alarms, camera systems, controlled and restricted public access, door locks, escape routes, locking of tools and medicines;

- work organization - limiting work in solitude, sufficient number of employees, motivation of employees, reduction of stress in the workplace, observance of breaks for food and rest, regulation of queues and provision of information about delays.

\section{Staff training}

The basic prerequisite for ensuring safety is the knowledge, skills and habits of employees at all levels. Some employees are familiar with the issue to a very limited extent, some are currently familiar with 
the issue. It is necessary to focus on the basic equipment of knowledge of a wider group of employees and in selected cases to provide specific training (corresponding to the needs in specific operations and positions). The needs of employees in this case differ to some extent, so different groups go through different training formats.

The knowledge and information gained during the training should be verified on practical model situations. In this case, there are two types of training. The first type of training was to be carried out with the active participation of the Police of the Czech Republic (simulation of an attack on the reception department). The second type of training would then be carried out under the supervision of the Police of the Czech Republic (activities and communication of the security team, attacks on the hospital premises, attacks on the hospital infrastructure, etc.). The course of all exercises should be uniformly structured (preparation of documentation, self-study of participants, technical support, briefing of participants, implementation of exercises, evaluation and feedback to participants). For the practice of the model situation of the hospital, a typical event that combines several possible security incidents seems to be especially useful. With regard to it regarding to it,

The specifics of the hospital are especially the requirements for possible evacuation of patients. In the case of an active shooter, it is important to evaluate the situation by hospital staff. In some cases, there will be a dilemma whether to stay with patients or not. Training in model situations in staff training shows that it is not entirely clear how staff should behave in a given situation, especially with regard to the rule: run / hide / fight. It is the training directly on the premises that should clearly show where there is room for improvement in the protection of the hospital as a soft target.

\section{Conclusion}

The issue of securing soft targets, especially medical facilities, is highly topical and complex. It is necessary to preserve all the freedom of the individual given by the legislation, but also to ensure his safety in the medical facility. It is important that soft target security plans have a crucial role to play in prevention (especially safety awareness and staff training) and in the event of a security incident until the components of the integrated rescue system take control of the situation. As terrorist attacks and other cases of active shooters have shown, the first minutes and preparedness for these emergencies play a crucial role in mitigating the impact of an incident.

The paper was prepared within the ČVUT Student Grant Competition SGS21 / 180 / OHK4 / 3T / 17.

\section{Literature}

BALICKÁ, K., (2005). Working with a client at risk in behavior: a good practice guide manual. Vyd. 1. Prague: Ministry of Labor and Social Affairs, ISBN 80-86878-27-9.

HAŠKOVCOVÁ, H., (2004). Manual on violence. 1st ed. Brno: National Center for Nursing and NonMedical Health Sciences, ISBN 80-7013-397-X.

HÁVA, P., (2004). Workplace violence in the field of health and social services in the Czech Republic: an initial theoretical study. Kostelec nad Cernymi lesy: Institute of Health Policy and Economics, ISBN 80-6625-21-4.

KALVACH, Z. et al., (2016). Basics of soft target protection - methodology. Version 1. Prague: Ministry of the Interior of the Czech Republic.

Ministry of the Interior of the Czech Republic. Terminological dictionary of terms from the field of crisis management, population protection, environmental security and state planning. Prague 2016. 129 p. [feeling. 2021-09-21]. Available from: Terminological Dictionary - Crisis Management and State Defense Planning - Ministry of the Interior of the Czech Republic (mvcr.cz). 
Ministry of the Interior of the Czech Republic, 2017. Concept of protection of soft targets for the years 2017-2020. [feeling. 2021-09-21]. Available from: http://www.mvcr.cz/soubor/koncepce-ochranymekkych-cilu-pro-2017-2020-pdf.aspx.

MV - DG HZS CR. MODULE - E; internal security and public order and selected chapters of crisis management. 2019. ISBN 978-80-7616-031-6.

Hospital of České Budějovice, as. 2020. Soft target coordination plan. Czech Budejovice.

NOVÁK, T., CAPPONI, V., (1996). Alone against aggression. Prague: Grada, ISBN 80-7169-253-0.

PONĚŠICKÝ, J., (2004). Aggression, violence and psychology of power. Vyd. 1. Prague: Triton, ISBN 80-7254-593-0. 
Fire Protection as Part of an E-learning Course on Security Issues at the Faculty

of Education of the Charles University

DOI: 10.36682/SSS_2021_11

PhDr. Miroslava Kovaříková, PhD.

$\begin{array}{cl}\text { Katedra pedagogiky } & \text { Department of Education } \\ \text { Pedagogická fakulta } & \text { Faculty of Education } \\ \text { Univerzita Karlova } & \text { Charles University } \\ \triangle \text { Magdalény Rettigové 4,116 39, Praha 1, Czech Republic } \\ \text { E-mail: Miroslava.Kovarikova@pedf.cuni.cz }\end{array}$

Mgr. František Hřebík, PhD.

\author{
Institut ekonomických studii Institut of Economics Studies \\ Masarykův ústav vyššich studii Masaryk Institute of Advanced Studies \\ České vysoké učení technické v Praze Czech Technical University in Prague \\ $\triangle$ Kolejni 2637/2a, 160 00, Praha 6, Czech Republic \\ E-mail: Frantisek.Hrebik@cvut.cz
}

\begin{abstract}
Annotation
The paper presents the evaluation of pilot verification of a module e-learning course on security issues for students of the follow-up master's programme. The paper brings information on the structure and contents of the course, as well as experience from the first year of its implementation. The text brings information on the results of a survey conducted among students who completed the course. The conclusion summarizes the results of the survey and their use for updating the course.
\end{abstract}

\title{
Key words
}

Fire protection, e-learning, security issues, evaluation of importance of the course, evaluation of difficulty of the course, evaluation of interest in the course.

\section{Introduction}

Inclusion of security issues to university education of teachers at the Faculty of Education of the Charles University takes place on the basis of implementation of the Government Decree No. 734, document "Incorporation of the topics Protection of people in extraordinary events, health care and road safety education to study programmes of faculties of education", although the current wording of the above decree is not binding in terms of implementation. The module e-learning course "Training before teaching practice" was launched at the Faculty of Education of the Charles University in winter semester of the academic year 2018/2019 (Note: hereinafter referred to as the course).

\section{Starting points}

In the academic year 2017/2018, the preparation of a course on security issues focused on common risks and extraordinary situations at school for undergraduate students of the Faculty of Education of the Charles University was launched. It was necessary to create the contents of the course, as well as prepare study texts for individual modules of the e-learning course. The preparation of the course was based on the recommendations of the European Agency for Safety and Health at Work (EU OSHA). The publication "Occupational safety and health and education: a whole-school approach" (Bruck, 2013) lists recommendations for successful inclusion of security issues to teachers' undergraduate training (Kovaříková, 2018). The following recommendations were used to create the course. 
1. Security education must be limited to key aspects using actual cases, problem-solving methods and active learning.

2. To incorporate the issue, use existing courses as updates of current subjects, in particular in common pedagogical preparation.

3. Make use of the possibilities of e-learning courses which offer students the option of individual fulfilment.

4. Cooperate with the Integrated Rescue System during the course preparation and implementation.

5. Cooperate with other universities engaged in teacher preparation and share materials on security issues.

As for the first point of the recommendation concerning the definition of key aspects of the issue, topics were defined based on discussion of selected academic staff with members of the inter-sector expert working group for security topics (Kovaříková, Hřebík, 2016). The following topics were determined:

- Common risks at school (injuries, first aid)

- Traffic safety

- Emergency situations (fire protection)

- Amok, armed attacker in school

- Selected school safety legislation

- Information security

As for the second point of the recommendation, on the use of existing courses, the courses Continuous Professional Practice at Primary School and Continuous Professional Practice at Secondary School were used for implementation. The course was presented as an update of the current texts for students in Moodle and was redesigned to e-learning structure, not as an introduction of a new course. (see recommendation no. 3). The course is completed with a certificate which the student prints themselves on the basis of an immediately automatically evaluated control test. The test includes control questions from all modules. Printed certificates are added to students' portfolios from professional practice. In creating the contents of the e-learning, we cooperated with professionals from the respective units of the Integrated Rescue System, particularly for the purpose of reviewing individual parts. (see recommendation no. 4) The course has currently been adopted and used by the Hussite Theological Faculty in Prague and negotiations with other institutions are underway. (see recommendation no. 5)

The course was opened to students in the academic year 2018/19. Students were trained before entering continuous professional practice.

\section{Methodology}

Data were collected electronically during May and June 2019. Individual modules of the course were anonymously evaluated by respondents in terms of selected criteria. The questionnaire included both closed and open-ended questions. Questions were focused on subjective evaluation and reflection of the course. This included the fulfilment of participants' expectations, usefulness and practical applicability of individual topics. We also learned about satisfaction with organization of education, methods used and professional level of education. Open-ended questions allowed to pass any recommendations for implementation. It was also examined how individual participants perceive tangible benefits of education for their work. We received a total of 148 questionnaires. The questionnaire measured 21 parameters evaluated by respondents on a 1 to 10 scale.

\section{Objectives of the survey}

To learn the evaluation of the new course in terms of its importance for actual teaching practice, evaluation of difficulty of individual topics in study and evaluation of interest in individual topics.

To use the data obtained to modify the course and learning curriculum of security issues and used educational methods, as well as for final text editing and creating methodology of security issues.

Hypotheses:

1. Respondents from practice (students of combined studies) generally evaluate the importance of the course and its benefits for practice at school as more important. 
2. Respondents from practice (students of combined studies) generally evaluate the importance of individual parts of the course as more important.

3. Respondents from practice (students of combined studies) generally evaluate the benefits of the course for practice at school as more important.

4. Number of years of experience affects the evaluation of total importance of the course.

5. Number of years of experience affects the evaluation of importance of individual parts of the course. 6. Number of years of experience affects the evaluation of benefits of the course for practice at school.

7. Among women, the total importance of the course was generally evaluated as more important.

8. Among women, the total importance of individual parts of the course was generally evaluated as more important.

\section{Methods}

Descriptive statistics and nonparametric statistical methods were used for the analysis. Mann - Whitney test, Spearman's Rank correlation coefficient and Somers' D coefficient. (HEBÁK, 2013). Data were tested to meet the assumption of normal distribution which was rejected based on the Shapiro-Wilk test. Since the data from the questionnaire are also ordinal, nonparametric statistical methods were used for further analyses.

Mann - Whitney test for two independent samples, the test compares medians, or the whole distribution of variables, and tests their conformity. As it is based on ordering of all measured values in ascending order of their size, it can also be used for ordinal variables. The test criterion $U$ is the number of all cases in which the values of one selection precede the values of the other. The hypothesis can be verified by comparing the resulting P-value with the significance level, usually chosen as $\alpha=5 \%$. If the P-value is greater than 0.05 , we cannot reject the tested hypothesis of the same level in the groups. On the contrary, it can be rejected at a value lower than 0.05 which proves dependence of the level on the factor observed (PECÁKOVÁ, Iva, 2011).

Spearman's Rank correlation coefficient

The Spearman's coefficient measures the intensity of dependence of the order of the characters of the variable observed. It is used to measure the association of two ordinal variables for which non-parametric testing is required. It takes values between $<-1 ; 1>$; extreme values denote absolute dependence, the sign indicates the direction: plus for direct, minus for indirect dependence. Lower values mean weak or moderate dependence. The statistical significance of this coefficient is verified using the test and its respective P-value. If it is lower than the selected significance level, often 0.05 , the dependence measured by the coefficient is considered statistically significant. The strength of the correlation is determined by the value of this coefficient (HEBÁK, Petr et al., 2013).

\section{Somers' D coefficient}

The Somers' coefficient measures the relationship between two ordinal variables. Its asymmetric variant can also take into account the direction of dependence. The extreme values from $\langle-1 ; 1\rangle$ indicate the strength of the association. The statistical significance of this coefficient can also be observed using the test and its respective P-value (HEBÁK, Petr et al., 2013). 


\section{Evaluation, descriptive statistics}

The sample of respondents consists of one tenth of men, the rest being women.

Graph 1: Gender of respondents

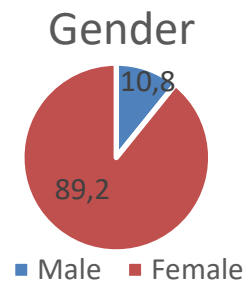

Source: Own research

Further identification data observed included type of studies. More than half of respondents has full-time studies, others study in combined studies. Only two respondents specified both types of study.

Graph 2.: Types of study.

Types of study

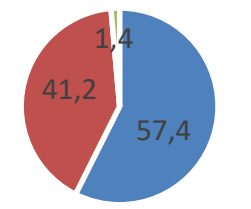

- Full time $=$ Combined $=$ Full time and combined

Source: Own research

In the introductory part of the questionnaire, respondents were asked whether the perceive the course as beneficial for teaching practice. According to $83.8 \%$ of respondents, the course is beneficial for teaching practice.

Graph 3: Perceive the course

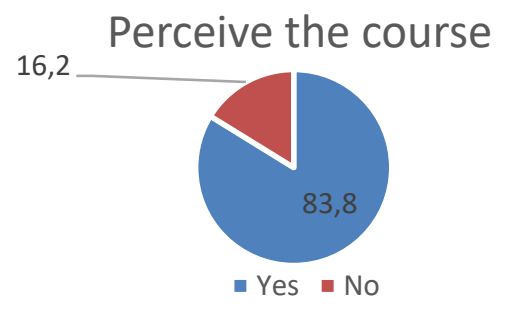

Source: Own research

Average time spent by studying the course was 4 hours, the middle median value of the coordinated set is 2 hours. The time ranges from 0 to 80 hours.

Evaluation of importance of the course:

The course was further evaluated in terms of importance for teaching practice, difficulty and interest in its contents. These three parameters were chosen as the key factors for students' motivation to study the course. (for more details, see for example Hrabal, Pavelková "Jaký jsem učitel"). Average evaluation of the course importance was 45.5 , with 29.7 for difficulty and 37.6 for interest. The middle median value 
of the coordinated set was 47 for importance, 30 for difficulty and 38 for interest. The most common modal value is for importance and 30 for both difficulty and interest. The ratings always range from 6 to 60 .

Tab.: 1 Evaluation of importance of the course

\begin{tabular}{|l|l|l|l|}
\hline & Importance & Difficulty & Interest \\
\hline Average & 45,5 & 29,7 & 37,6 \\
Middle median & 47 & 30 & 38 \\
Modus & 60 & 30 & 30 \\
Standard deviatic & 11,277 & 12,228 & 12,687 \\
Minimum & 6 & 6 & 6 \\
Maximum & 60 & 60 & 60 \\
\hline
\end{tabular}

Source: Own research

Graph 5: Evaluation of importance of the course

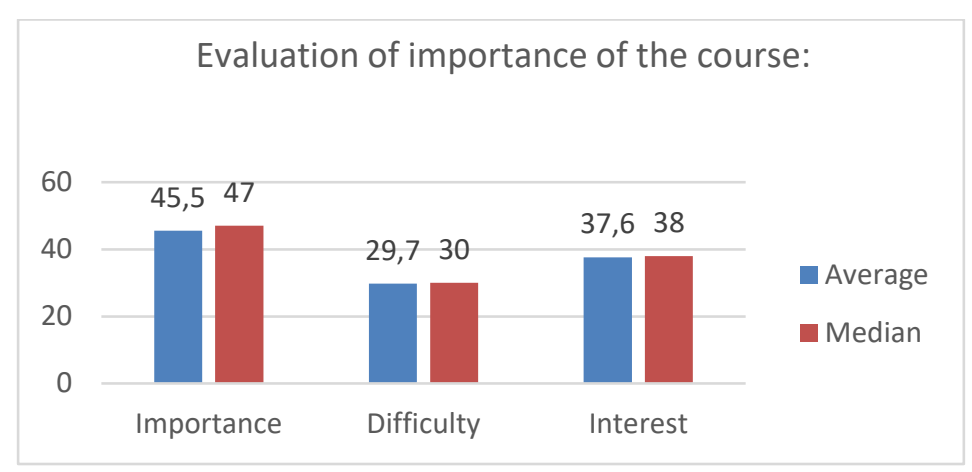

Source: Own research

Evaluation of difficulty of the course

The highest average evaluation of difficulty of the course is 5.4 for school legislation, 5.2 for information security and 5.0 for active shooter.

Graf 6: Evaluation of difficulty of the course

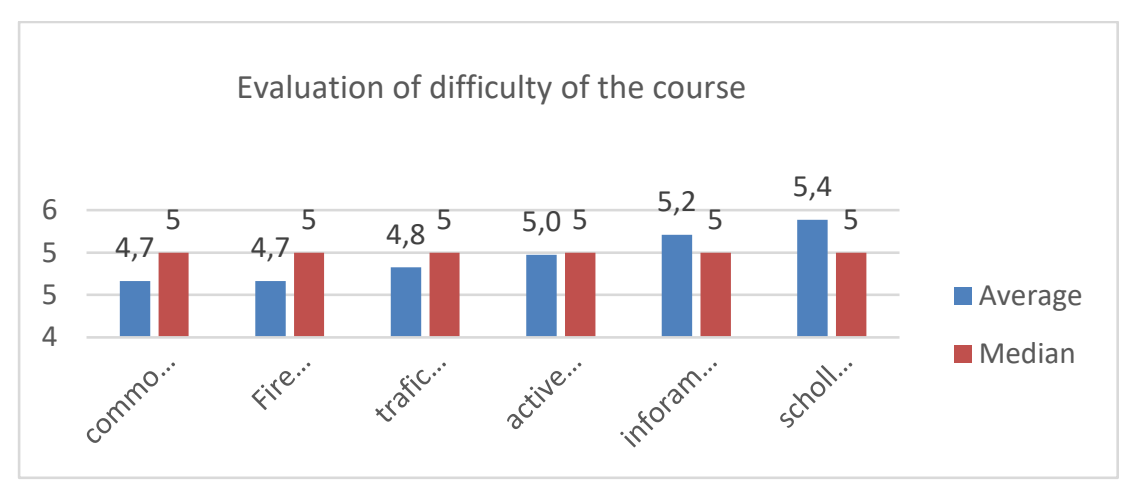

Source: Own research

Evaluation of interest in the course

The highest average evaluation of interest in the course is 7.0 for active shooter, followed by 6.6 for traffic safety and 6.6 for common risks at school. 
Graf 7: Evaluation of interest in the course

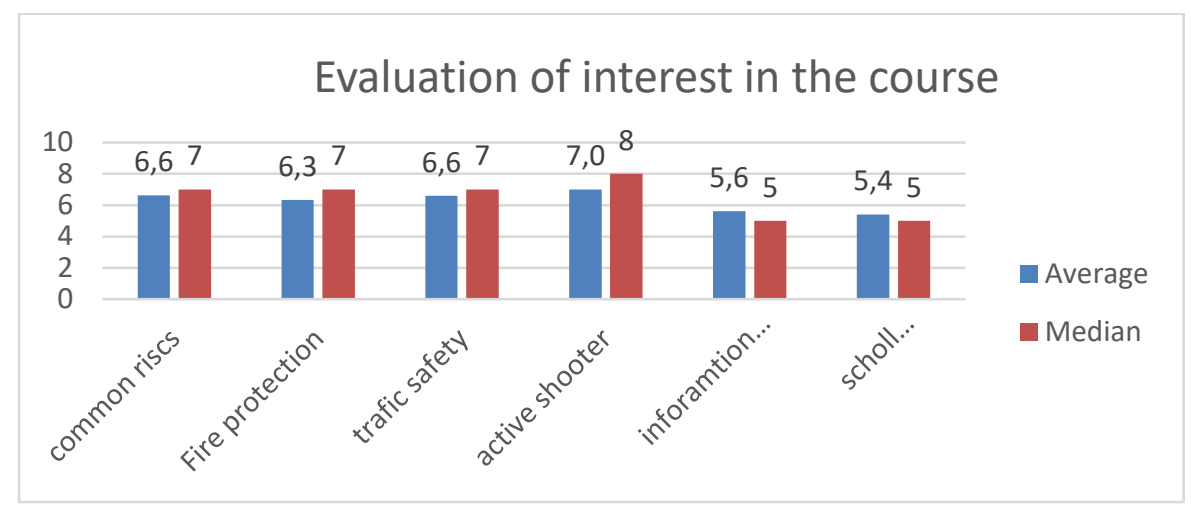

Source: Own research

\section{Testing of hypotheses}

Hypothesis 1: Respondents from practice (students of combined studies) generally evaluate the total importance of the course as more important

According to both average and median values of total evaluation of importance, students of full-time studies indicate higher importance. According to the Mann-Whitney test, however, the difference is not statistically significant as the resulting P-value is higher than 0.05 . Moreover, even according to Somers' $\mathrm{D}$, there was no statistically significant dependence of importance evaluation on the type of studies.

The hypothesis that respondents from practice (students of combined studies) generally evaluate the total importance of the course as more important was therefore not proven.

Tab.:2 Total importance

\begin{tabular}{|lll|l|}
\hline & & \multicolumn{2}{c|}{ Total importance } \\
& Average & Median \\
\hline \multirow{2}{*}{$\begin{array}{l}\text { Types } \\
\text { study }\end{array}$} & of Full time & 46,4 & 49 \\
\cline { 2 - 4 } & Combined & 45,0 & 46 \\
\cline { 2 - 4 } & total & 45,5 & 47 \\
\hline
\end{tabular}

Source: Own research

Tab.: 3 Test Statistics

\begin{tabular}{|ll|}
\hline Test Statistics & \\
& \\
& Importance \\
\hline Mann-Whitney U & 2230,000 \\
\hline Wilcoxon W & 4121,000 \\
\hline Z & $-1,440$ \\
\hline Asymp. Sig. (2-tailed) &, 150 \\
\hline & \\
\hline a. Grouping Variable: study & \\
\hline
\end{tabular}

Source: Own research 
Tab.4: Directional measures

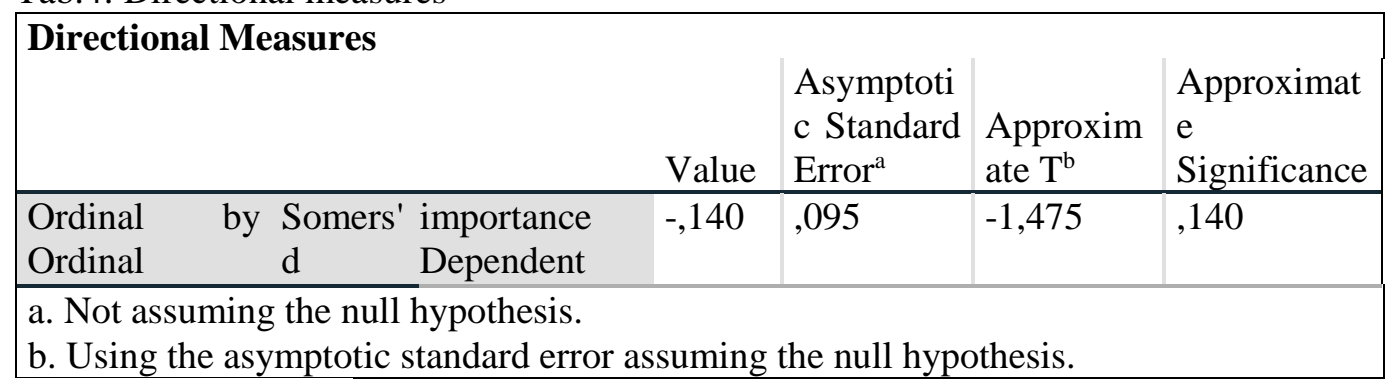

Source: Own research

Hypothesis 2: Respondents from practice (students of combined studies) generally evaluate the importance of individual parts of the course as more important

According to both average and median values of evaluation of importance, students of full-time studies indicate similar evaluation of importance as students of combined studies in all parts of the course apart from "Information security, GDPR", where students of combined studies indicate much lower importance. In this part only the difference according to the Mann-Whitney test was statistically significant as the resulting P-value is lower than 0.05. Also, according to Somers' D, in this part only there was a statistically significant dependence of importance evaluation on the type of studies with students of combined studies usually indicating lower evaluation of importance. However, according to the coefficient value of 0.325 , this dependence is very weak.

The hypothesis that respondents from practice (students of combined studies) generally evaluate the importance of individual parts of the course as more important was therefore proven only for the "Information security, GDPR" part.

Tab.5: Test Statistics

\begin{tabular}{|lll|l|l|l|l|l|}
\hline & $\begin{array}{l}\text { Common risks } \\
\text { at school } \\
\text { Average }\end{array}$ & $\begin{array}{l}\text { Fire } \\
\text { protection } \\
\text { Average }\end{array}$ & $\begin{array}{l}\text { Trafic } \\
\text { safety } \\
\text { Average }\end{array}$ & $\begin{array}{l}\text { Armed } \\
\text { attacker } \\
\text { Average }\end{array}$ & $\begin{array}{l}\text { Informatio } \\
\text { n security } \\
\text { Average }\end{array}$ & $\begin{array}{l}\text { School } \\
\text { legislatio } \\
\text { Average } \\
\text { Avtics }\end{array}$ & Averang \\
\hline $\begin{array}{l}\text { Types } \\
\text { of study }\end{array}$ & Full time & 8,4 & 7,8 & 7,9 & 7,2 & 7,9 & 7,3 \\
\cline { 2 - 8 } & Combined & 8,2 & 8,0 & 7,9 & 7,2 & 6,4 & 7,3 \\
\hline
\end{tabular}

Source: Own research

Tab.6: Test Statistics

\begin{tabular}{|c|c|c|c|c|c|c|}
\hline Test statistics & $\begin{array}{l}\text { Common risks } \\
\text { at school } \\
\text { Median }\end{array}$ & $\begin{array}{l}\text { Fire } \\
\text { protection } \\
\text { Median }\end{array}$ & $\begin{array}{l}\text { Trafic } \\
\text { safety } \\
\text { Median }\end{array}$ & $\begin{array}{l}\text { Armed } \\
\text { attacker } \\
\text { Median }\end{array}$ & $\begin{array}{l}\text { Informatio } \\
\text { n security } \\
\text { Median }\end{array}$ & $\begin{array}{l}\text { Schoo } \\
1 \\
\text { legisla } \\
\text { tion } \\
\text { Media } \\
\mathrm{n} \\
\end{array}$ \\
\hline \multirow{3}{*}{$\begin{array}{l}\text { Types of } \\
\text { study }\end{array}$} & 9 & 8 & 8 & 8 & 8 & 8 \\
\hline & 9 & 8 & 8 & 7 & 6 & 7 \\
\hline & 9 & 8 & 8 & 8 & 8 & 8 \\
\hline
\end{tabular}

Source: Own research 
Tab.7: Test Statistics

\begin{tabular}{|l|l|l|l|l|l|l|}
\hline Test Statistics $^{\mathbf{a}}$ & $\begin{array}{l}\text { Common risks } \\
\text { at school }\end{array}$ & $\begin{array}{l}\text { Fire } \\
\text { protection }\end{array}$ & $\begin{array}{l}\text { Trafic } \\
\text { safety }\end{array}$ & $\begin{array}{l}\text { Armed } \\
\text { attacker }\end{array}$ & $\begin{array}{l}\text { Informatio } \\
\text { n security }\end{array}$ & $\begin{array}{l}\text { School } \\
\text { legislation }\end{array}$ \\
\hline Mann-Whitney U & 2351,500 & 2580,000 & 2536,000 & 2542,500 & 1749,000 & 2591,500 \\
\hline Wilcoxon W & 4242,500 & 6235,000 & 4427,000 & 4433,500 & 3640,000 & 4482,500 \\
\hline Z &,- 998 &,- 051 &,- 231 &,- 201 & $-3,389$ &,- 004 \\
\hline $\begin{array}{l}\text { Asymp. Sig. (2- }, 318 \\
\text { tailed) }\end{array}$ &, 959 &, 817 &, 840 &, 001 &, 997 \\
\hline a. Grouping Variable: study & & & & & & \\
\hline
\end{tabular}

Source: Own research

Tab.8: Test Statistics

\begin{tabular}{|c|c|c|c|c|}
\hline \multicolumn{5}{|l|}{ Directional Measures } \\
\hline Ordinal by Ordinal Somers' d & Value & $\begin{array}{l}\text { Asymptotic } \\
\text { Standard } \\
\text { Error }^{\mathrm{a}}\end{array}$ & $\begin{array}{l}\text { Approxim } \\
\text { ate } T^{b}\end{array}$ & $\begin{array}{l}\text { Approximate } \\
\text { Significance }\end{array}$ \\
\hline $\begin{array}{l}\text { Common risks at school } \\
\text { Dependent }\end{array}$ &,- 093 &, 092 & $-1,006$ & 315 \\
\hline $\begin{array}{l}\text { Fire protection } \\
\text { Dependent }\end{array}$ &, 005 & ,093 &, 052 & ,959 \\
\hline $\begin{array}{l}\text { Trafic safety } \\
\text { Dependent }\end{array}$ &,- 022 & ,094 &,- 233 & ,816 \\
\hline $\begin{array}{l}\text { Armed attacker } \\
\text { Dependent }\end{array}$ &,- 019 &, 095 &,- 203 & ,839 \\
\hline $\begin{array}{l}\text { Information security } \\
\text { GDPR Dependent }\end{array}$ &,- 325 & ,092 & $-3,521$ & ,000 \\
\hline $\begin{array}{l}\text { School } \\
\text { legislation } \\
\text { Dependent }\end{array}$ &,- 038 & ,094 &,- 405 & ,685 \\
\hline
\end{tabular}

Source: Own research

Hypothesis 3: Respondents from practice (students of combined studies) generally evaluate the benefits of the course for practice at school as more important.

According to average values of evaluation of the course benefits, students of combined studies usually indicate somewhat higher importance (in $90 \%$ of cases). According to the Mann-Whitney test, however, the difference is not statistically significant as the resulting P-value is higher than 0.05. Moreover, even according to Somers' D, there was no statistically significant dependence of benefit evaluation on the type of studies.

The hypothesis that respondents from practice (students of combined studies) generally evaluate the benefits of the course for practice at school as more important was there not proven.

Other results observed.

Hypothesis 4: Number of years of experience affects the evaluation of total importance of the course.

The hypothesis that the number of years of experience affects the evaluation of total importance of the course was not proven.

Hypothesis 5: Number of years of experience affects the evaluation of importance of individual parts of the course. 
The hypothesis that the number of years of experience affects the evaluation of total importance of the course was proven only for the "Information security, GDPR" part.

Hypothesis 6: Number of years of experience affects the evaluation of benefits of the course for practice at school.

The hypothesis that the number of years of experience affects the evaluation of benefits of the course for practice at school was not proven. Another monitored dependence was the relationship between the importance and benefit evaluation by gender.

Hypothesis 7: Among women, the total importance of the course was generally evaluated as more important

The hypothesis that among women, the total importance of the course was generally evaluated as more important, was proven.

Hypothesis 8: Among women, the total importance of individual parts of the course was generally evaluated as more important.

The hypothesis that among women, the total importance of individual parts of the course was generally evaluated as more important, was proven for three parts: "Common risks at school", "Fire security" and "Active shooter".

\section{Conclusion}

The results of the questionnaire survey showed that students evaluate the course on security issues as important for practice and interesting. Since the course is perceived as not difficult, it can be assumed that the chosen form of e-learning course enabled all students to complete the course with an average duration of four hours. In the short period of one year, this form allowed to provide basic training in security issues to a total of $89 \%$ of all students of the follow-up master's studies. A total of $22 \%$ of all trained students provided feedback.

The first year of the course showed the necessity of further updating existing topics of the course and adding more module units to the course. A new module focusing on pupils' trips abroad, overnight events, safety during specific activities and other extraordinary situations is currently planned.

It is pleasant that the Faculty of Education of the Charles University takes security issues for teachers as integral part of undergraduate training and the proposed new accreditation includes these issues in direct teaching of common basis.

\section{Literature}

BRUCK, K., (2013). Occupational safety and health and education: a whole-school approach. Bilbao: EU-OSHA. Facts 82, Luxemburg.

HEBÁK, P. a kolektiv. (2013) Statistické myšlení a nástroje analýzy dat. 1.vyd. Praha: INFORMATORIUM. ISBN:978-80-7333-105-4

KOVAŘIKOVÁ, M., MARÁDOVÁ, E. (2020) Didaktika výchovy ke zdravi a bezpeči v kontextu kutikulární reformy a učitelského vzdělávání. Praha: Pedagogická fakulta Univerzity Karlovy.182 s. ISBN 978-80-7603-142-5

PECÁKOVÁ, I. (2011) Statistika v terénnich pri̊zkumech. 2. dopl. vyd. Praha: PROFESSIONAL PUBLISHING EAN 9788074310393 
KOVAŘIKOVÁ, M., (2018) Evropské tendence ve vzdělávání v oblasti podpory zdraví a bezpečnosti. In MUŽÍK, V.(eds.) Život ve zdraví 2018.Brno: Pedagogická fakulta Masarykovy univerzity, 2018 s.5356 ISBN 978-80-210-9176-4

KOVǍ̌IKOVÁ, M., HŘEBÍK, F. (2016) Prevention of Armed Assaults at schools and Universities in the Czech Republic. International Advances in Economic Research. vol. 22, no. 3, pp. 2 ISSN 10830898. DOI 10.1007/s11294-016-9609-5 
DOI: 10.36682/SSS_2021_12

\author{
doc. Ing. Otakar Jiri Mika, CSc. \\ Department of Crisis Management Department of Crisis Management \\ Faculty of Security Management Faculty of Seurity Management \\ Police Academy of the Czech Republic in Prague Police Academy of the Czech Republic in Prague \\ $\triangle$ Lhotecká 559/7, PO Box 54, 14301 Praha 4, Czech Republic \\ Email: mika@polac.cz \\ doc. Ing. Jozef Sabol, DrSc. \\ Department of Crisis Management Department of Crisis Management \\ Faculty of Security Management Faculty of Seurity Management \\ Police Academy of the Czech Republic in Prague Police Academy of the Czech Republic in Prague \\ $\triangle$ Lhotecká 559/7, PO Box 54, 14301 Praha 4, Czech Republic \\ Email: sabol@polac.cz.
}

\begin{abstract}
Annotation
Professional discussions about missing The National Strategy and the National Action Plan for Protection against CBRN Threats aimed at population protection and general preparedness for CBRN issues. The necessary improvement of interconnected chain of preventive, protective, rescue, mitigation, response and recovery measures in the conditions of the Czech Republic. Academic reflections, expert discussions dealing with the above-mentioned areas in the Czech Republic with presenting serious technical points focused on CBRN terrorism. Conclusions and recommendations how to improve the current situation including suggestions for basic methodological procedures of the first responders.
\end{abstract}

\title{
Key words
}

CBRN threats, CBRN protection, CBRN preparedness, national strategy, national action plan, population protection, first responders, rescue workers

\section{Introduction}

CBRN incidents are on the rise and threats, vulnerabilities and modus operandi of offenders need to be clearly understood for reliable prevention and rapid, effective and reliable response. CBRN incident management, both prevention and response, is a matter for multiple government institutions and agencies seeking to coordinate with each other and have a clear understanding of the rules and jurisdictions. Any response must be swift and coordinated to prevent victims and prevent the escalation of such an adverse event.

The Czech government and the Czech authorities consider security issues to be key issues in the state's internal policy. The concern is justified because, for example, the Metro system is in a closed environment and is an easy target for terrorists. In 1995, Japan's Aum Shinrikyo attacked the Tokyo subway with sarin and caused 13 deaths and nearly 7,000 injuries (Tu 2002, Tu 2018).

Therefore, it is important for the Czech Republic to seriously consider protection against chemical, biological and radiological terrorism in vulnerable public places (for example in the Prague metro), but also in all possible CBRN scenarios. 


\section{CBRN Threats in the Czech Republic}

It can be stated that the Czech Republic has not lagged behind in such an important area as CBRN protection. Among other things, the solution of the state scientific research project for the Ministry of the Interior from 2002 to 2003 entitled New Terrorist Threats - Chemical, Biological, Radiological and Nuclear Terrorism is a clear proof of this. (Matoušek 2003) On the basis of this scientific and research grant, student texts were prepared and published in time at the University of Defense in Brno in 2005 (Matoušek 2005).

Brand new specialized publications entitled Nuclear, Radiological and Chemical Weapons, Radiation and Chemical Accidents (Vičar 2020) and Protection against Weapons of Mass Destruction in the Czech Republic (Sabol 2021) were published at universities in the Czech Republic.

The issue of the executive and control body, which in the Czech Republic is the State Office for Nuclear Safety (State Office for Nuclear Safety 2021), is also crucial. It could escape the uninformed that the state authority, which has nuclear safety in its name, also includes the following three major professional areas, such as:

- Non-proliferation,

- Prohibition of chemical weapons,

- Prohibition of biological and toxin weapons.

In another case, the habilitation thesis from 2011 (Mika 2011) includes only the issue of protection of the population against chemical terrorism, where a total of 91 different measures were proposed in specific parts: preventive measures, repressive measures, rescue and protection measures, liquidation measures and recovery.

Good preparedness of all persons (rescuers, rescuers, medical personnel, police, special hospitals, special units from the army, population, etc.) Emergencies, especially to manage their consequences, including possible terrorism CBRN attacks require in particular the following necessary procedures (Mika 2011):

- Systematic preparation of control units and bodies for the possibilities of CBRN terrorism;

- Sufficient knowledge of CBRN terrorism acquired by the population (awareness of the population about possible emergencies and emergencies at the place of residence or work, including terrorist attacks; specification of warning methods and protection of the population; answers answered, etc. by administrative authorities at the place of residence);

- Basic equipment of the population with written instructions on CBRN terrorism and proper response of the population (description of possible emergencies on the spot, including terrorist attacks; method of warning the population; shelters for the population and protection system; improvised protective equipment and aids evacuation);

- Practical training of residents for cases of CBRN attacks; drilling activities and the use of various personal protective equipment and aids; production of improvised protective equipment; evacuation baggage training; evacuation training; shelter training; comprehensive training of acquired skills and habits; training the population in response to possible emergencies and emergencies);

- Theoretical training of rescuers and police officers for CBRN attacks (gaining the necessary basic knowledge of the problems);

- Practical training of intervening persons, rescuers and police officers on training grounds and in CBRN terrorism exercises (acquisition of the necessary skills and habits for operations in emergencies and emergency situations [terrorist attacks]), and

- Systematic, regular and comprehensive verification of knowledge, skills and habits of rescuers through not only written tests, but also practical verification in the field.

Overall civilian preparedness for emergencies, emergencies and their adverse effects is a very complex, complicated and long-term matter. In the Czech Republic, a system of preparation of all groups of the population for extraordinary events and emergencies has not yet been created (only very partially for 
primary school pupils and secondary school students). An integral part of such preparation must be regular and systematic preparation of the population for possible CBRN attacks.

Terrorist groups are constantly exploring all possible ways to cause mass attacks on certain targets owned by the West and the United States, especially to disrupt the Western way of life. A massive attack on crowded public places such as airports, large supermarkets, sports stadiums, etc., would not only cause hundreds of casualties and injuries, but would also cause other major damage. However, terrorists can easily smuggle large amounts of toxic substances or explosives into the above-mentioned public places, leading to a mass terrorist event. Terrorists could easily misuse dangerous biological agents or radioactive materials for their purposes.

Just imagine what could have happened at the capital's airport if the attacker had not been armed only with automatic weapons, but simply used a bottle of sarin [cyclosarin, soman, tabun]. How would we deal with such a terrible chemical event?

Many countries have already begun to prepare for prevention and response, although most have not been prepared for CBRN threats. Usually, the response is based on the capabilities of the guards and local first response services.

\section{National Strategy and National Action Plan for CBRN Protection}

The current situation in the field of CBRN in the Czech Republic is at a relatively good level, but the state of preparedness needs to be constantly improved. On the other hand, the Czech Republic still does not have a developed national strategy and national action plan for the protection of the CBRN, which would focus mainly on the protection of the population, the protection of intervening rescuers, etc.

The Czech Republic has gradually developed so-called several large and detailed type plans (emergency response plans) for the main important areas of the CBRN, as set out below:

- Response to the abuse of biological warfare agents and biological agents against the population (General Directorate of the Fire and Rescue Service of the Czech Republic, Type Activity 2006),

- Reaction to a dirty bomb or other dangerous radioactive materials (General Directorate of the Fire and Rescue Service of the Czech Republic, Type Activity 2015),

- Reactions to the misuse of chemical warfare agents and toxic industrial chemicals in Metro i (General Directorate of the Fire and Rescue Service of the Czech Republic, Type Activity 2013).

Despite the fact that the above-mentioned Emergency Response Plans cover the CBRN area relatively comprehensively, we still see certain professional gaps. Therefore, it would be very useful and beneficial to create a National CBRN strategy in the Czech Republic and subsequently a National CBRN action plan for the protection of the population and professional rescuers, etc.

The great advantage is the indisputable fact that many developed countries have such documentation created and are mostly publicly available (an example of Canada is given below). The already created documentation can be very inspiring for the Czech Republic to a large extent.

In the previous several professional works, including the mentioned habilitation thesis, various detailed and variant scenarios of chemical terrorism are presented. (Mika 2011)

It may seem that such expert and relatively detailed scenarios can be inspiring and, in a way, a kind of guide to carrying out a terrorist attack. On the other hand, the necessary main and fundamental reason for creating possible terrorist scenarios must be seen. To find the best, fastest and most reliable ways to rescue and protect against CBRN terrorism, we must cleverly create fictitious but realistic terrorist attack scenarios that will be the basis for countermeasures throughout a complex and interconnected chain of action.

Here we should list chronologically the areas from prevention, detection, identification and monitoring of hazardous substances, through evacuation, protection, rescue, medical care, safe and rapid care of 
victims, hospitalization of affected persons and rescuers to decontamination, restoration and reconstruction of affected and contaminated areas.

Basic proposal of the CBRN strategy for the fight against CBRN terrorism and protection of the population in the conditions of the Czech Republic, which was published in 2015 at the CSCM - World Congress on CBRN Science and Consequence Management in Croatia (Mašek 2015):

1. Distribute a small brochure on the main threats to CBRN and CBRN defense [at several different levels: for the public and for all the different members of the rescue services, rescue staff, hospital staff]. 2. Equip selected crowded public places [such as the metro, airports, large supermarkets, sports stadiums, concert halls, large cinemas] with fast and reliable detection devices for chemical, biological and radiation detection.

3. Train security and local professional staff in handling CBRN events and the immediate steps necessary to survive such an event.

4. Provide escape masks to local personnel as part of their professional uniforms and standard equipment.

5. Train and train guards and other security personnel in the use of escape masks and their immediate distribution to vulnerable persons at the site of a CBRN incident.

6. Prepare simple and clear messages in advance as warning notices [for each emergency: chemical, biological and radioactive], which instruct and guide the affected population to evacuate buildings as quickly as possible.

7. Train and train local medical teams (paramedics and hospital staff) to perform rapid clinical identification of the incident and possible medications that are used for rapid and reliable treatment.

8. Prepare and test local escape systems and professional personnel for rapid evacuation of the entire population to a safe area.

9. Improve preparedness for dealing with people within and around contaminated areas.

10. Create a combined doctrine involving all participating organizations on site and with local rescuers. 11. Establish command and control of rescue operations in a protected and clean environment until the transfer of responsibilities to the basic and other components of the integrated system, including the decontamination of rescuers and victims outside the contaminated area.

12. Train and train all local guards, agencies and organizations and improve their knowledge, experience and preparedness for CBRN events.

Useful models and inspiration can be found in developed foreign countries, such as Canada. Some older strategies and action plans are as follows (see these examples, which can be found on the website):

- CBRNE Strategic Plan 2011 - 17 pages (Her Majesty the Queen in Right of Canada and 2011); and

- CBRNE Action Plan 2011 - 12 pages (Her Majesty the Queen in Right of Canada b 2011).

We can expect that in addition to Canada, which was mentioned, strategic and action plans for CBRN in other developed countries, including the Czech Republic, have been and will be prepared, discussed, implemented and used.

The problem of dealing with emergencies and emergencies is at a very high level in Canada. In addition, various manuals, aids, instructional documents, recommendations, management plans and videos are easily accessible on the website. Why not learn from the experienced, why not use what has already been done and what has worked? It might be useful to establish fruitful international cooperation in this area (Mašek 2015).

The most important element of the whole process is the reliable collection of the most accurate information about the CBRN event for the authorities. This will create the necessary conditions for a quick and correct decision on the need to take various measures. Obtaining the necessary information about the location of the event, the nature of the event and the results of the first measurements, as well as information about the number of victims and injured and affected persons, the extent of contamination and other damage is undoubtedly very important. In addition, the correct and fast evaluation of the event by the control center is crucial (Mašek 2015). 
Slow, erroneous and incorrect evaluation of information leads to incorrect and erroneous conclusions and thus to incorrect deployment of forces and equipment. This can result in higher casualties, injuries to human health and higher damage. In such a case, higher costs for resolving the CBRN event can be expected.

Based on the results of the evaluation, it is then possible to determine the size of the contaminated area, where it is necessary to use personal protective equipment.

The extent of the CBRN event is another very important indicator. Depending on the scope of the CBRN action, it is then decided whether to strengthen forces and equipment from the level of other regions, from the governmental level (central) or to request international assistance. To that end, it is appropriate to request immediate international assistance in the form of immediate contact with the Joint Emergency and Information System (CECIS). It is an exchange of information between the affected area and CECIS, but also an exchange of information and specific assistance from other countries in managing the CBRN event (Mašek 2015).

The following are typical and necessary equipment for rescue teams and groups to intervene and manage CBRN events:

- Detection, identification and monitoring equipment for the detection of dangerous substances or for the determination of the presence of radiation or contamination (based on the type of CBRN event);

- Individual respiratory protection equipment and individual body protection equipment according to the type of CBRN event (eg protective mask, respirator, protective clothing, protective footwear, protective gloves, etc.);

- Special sample sets for the safe collection of dangerous substances for subsequent thorough analysis to confirm previously found data on the radiological, chemical and biological situation;

- Decontamination solutions and mixtures for the decontamination of intervention and rescue teams, namely personnel, equipment and materials used and for the decontamination of contaminated areas;

- Safe and reliable equipment for marking and clear marking of decontaminated (dangerous) area;

- Communications and means of transport; and

- Additional specific equipment of the group according to the CBRN event (Mašek 2015).

\section{Conclusion}

Terrorism is a global threat that has increased in importance since 11 September 2001. The current situation calls for the introduction of globally applicable measures aimed not only at defeating terrorists but also at alleviating the poverty of nations that is being exploited by terrorists to achieve their goals. However, the causes of terrorism are not easy to fully and thoroughly identify. (Kysilko 2015)

Cruel, brutal and violent terrorist acts are planned to act in public and to provoke shock and stress throughout nations. Negative experiences resulting from the horrors and memories of dead and affected victims will have a lasting impact on all those affected by the attack, as well as their families and relatives, friends and acquaintances (Kysilko 2015).

State and intelligence services, together with the police and state authorities, must thoroughly and purposefully focus on exposing any preparations for terrorist attacks in order to prevent such acts of violence around the world. In particular, great attention must be paid to important CBRN issues and the related rapid and reliable protection of the population, as well as to rescuers, hospital staff in the Czech Republic and in other countries. CBRN terrorism could cause a very large number of victims. It is clear that new terrorist threats will not escape the Czech Republic.

If the proposed management system would save a single human life (however, it can protect and save tens, hundreds, if not thousands), it is undoubtedly worth it. The Czech Republic has many important professional publications that could be a good support in the creation of the National Protection Strategy 
in the field of CBRN and the National Action Plan for this area created in connection with it (Fišerová 2010).

It is important to emphasize that an experienced team of selected CBRN experts is the germ of a necessary temporary working group that could analyze, evaluate and discuss the area and propose a comprehensive solution. This can be implemented both as a public contract of the Ministry of the Interior of the Czech Republic and as a national security project within the public tender in the field of security at universities or other research and development workplaces and organizations in the Czech Republic.

A number of foreign professional monographs (Richardt 2013) as well as many important foreign journals specializing in CBRNe, such as the British trade journals Chemical, Biological, Radiological, Nuclear and Explosice World (abbreviated CBRNe World, ISSN 2040-2724) or Chemical Biological and Nuclear Warfare (abbreviated CBN Warfare, ISSN 2051-6584). In the last issue, the latter professional magazine brought, among other things, interesting and useful information about the socalled "escape masks" (Williams 2021), or about modern detection systems. (Mallet 2021).

The contribution was processed within the framework of the grant VI20192022171 (VI3VS / 716).

\section{Literature}

General Directorate of the Fire and Rescue Service of the Czech Republic, (2006) STČ 05 / IZS Finding of a subject with suspected presence of B-agents or toxins, Type activity, Prague.

General Directorate of the Fire and Rescue Service of the Czech Republic, (2015) STČ 01 / IZS Špinavá bomba, Typová činnost, Praha.

General Directorate of the Fire and Rescue Service of the Czech Republic, (2013) STČ 13 / IZS Reaction to chemical attack in the metro, Type activity, Prague.

Her Majesty the Queen in Right of Canada a, (2011) Chemical, Biological, Radiological, Nuclear and Explosives Resilience Strategy for Canada, ISBN 978-11-100-17623-9.

Her Majesty the Queen in Right of Canada b, (2011) Chemical, Biological, Radiological, Nuclear and Explosives Resilience Action Plan for Canada, ISBN 978-11-100-17649-9.

FIŠEROVÁ, L., MIKA, OJ, (2010) Current Crisis Management and Emergency Planning in the Czech Republic, Brno University of Technology, Faculty of Chemistry, Brno, ISBN 978-80-214-4085-2.

KYSILKO, P., MIKA, O., J., VIČAR, D., (2015) Protection against Chemical Terrorism in the Prague Subway. NBC-2015 Symposium Proceedings - How does the land scape envolve? Association for Protection, Rescue, Security and Safety, pp. 33-38, Helsinki, ISBN 978-952-93-5587-7.

MAŠEK, I., MIKA O., J., VIČAR, D., (2015) CBRN Issues in the Czech Republic, Conference Proceedings from the CSCM - World Congress on CBRNe Science and Consequence Management, 1217 April 2015, Zagreb, Croatia.

MAŠEK, I., MIKA, O., J., PRINC, I., VIČAR, D., (2020) Nuclear, radiological and chemical weapons, radiation and chemical accidents [specialized monograph], Tomas Bata University in Zlín, Faculty of Logistics and Crisis Management, Uherské Hradiště, ISBN 978-80-7454-947-2.

MATOUŠEK, J., MIKA, O., J., NAVRÁTIL., T., (2003) New threats of terrorism: chemical, biological, radiological and nuclear terrorism [state security project], ISATech, sro Pardubice.

MATOUŠEK, J., MIKA, O., J., VIČAR, D., (2005) New threats of terrorism: chemical, biological, radiological and nuclear terrorism [textbook], University of Defense, Brno 2005, ISBN 80-7231-037 2 .

MALLET, G., (2021) A bubble for armored vehicles, Chemical Biological and Nuclear Warfare, No. 2, 2021, pp. 47-50, ISSN 2051-6584. 
MIKA, O., J., (2011) Protection of the population against chemical terrorism in the Czech Republic [habilitation thesis], Brno University of Technology, Faculty of Chemistry, Brno.

RICHARDT, A., et al. (2013) CBRN Protection, Managing the Threat of Chemical, Biological, Radioactive and Nuclear Weapons, WILEY-VCH Verlag GmbH \& Co. KGaA.

SABOL, J., MIKA, O., J., POLÍVKA, L., ŘIIHA, M., ZEMAN, M., (2021) Protection against weapons of mass destruction in the Czech Republic [professional monograph], Police Academy of the Czech Republic in Prague, Faculty of Security Management, Department of Crisis Management, ISBN 97880-7251-511-0.

State Office for Nuclear Safety, 2021, 30.9.2021 [cited. 2021-09-30]. Available from WWW http://www.sujb.cz/

TU, A., T., (2002) Chemical Terrorism: Horrors in Tokyo Subway and Matsumoto City, Alaken, Inc .: Fort Collins, Colorado, USA, ISBN 1-880293-10-2.

TU, A., T., (2018) Chemical and Biological Weapons and Terrorism, CRC Press, ISBN-13: 978113803-33-82.

WILLIAMS, T., (2021) Portable Protection, Chemical Biological and Nuclear Warfare, No. 2, 2021, pp. 54-56, ISSN 2051-6584. 
DOI: 10.36682/SSS_2021_13

\title{
Prof. Ing. Roman Rak, Ph.D.
}

Katedra: Bezpečnosti a práva Department: Security and Law Univerzita: Ambis, Vysoká škola University: Ambis University. $\triangle$ Lindnerova 575/1, 18000 Prague 8-Liben, Czech Republic E-mail:Rak.Roman@seznam.cz

\section{JUDr. Dagmar Kopencová, Ph.D.}

Katedra: Bezpečnosti a práva Department: Security and Law Univerzita: Ambis, Vysoká škola University: Ambis University. $\triangle$ Lindnerova 575/1, 18000 Prague 8-Liben, Czech Republic E-mail: Dagmar.Kopencova@seznam.cz

Doc. JUDr. Miroslav Felcan, PhD., LL.M., dr. h. c.

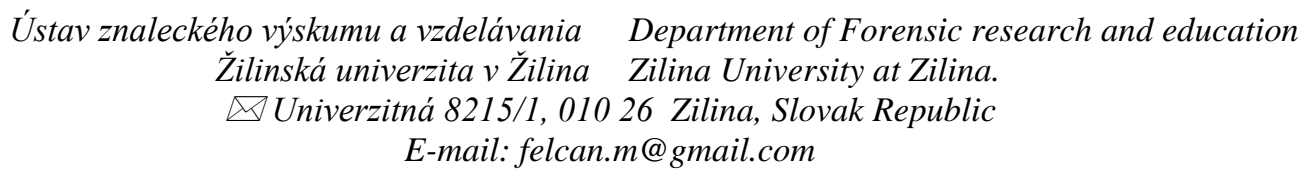

Ing. Frantisek Vlach, Ph.D., MBA, LL.M., Ing-Paed IGIP

Katedra: Bezpečnosti a práva Department: Security and Law Univerzita: Ambis, Vysoká škola University: Ambis University. $\triangle$ Lindnerova 575/1, 18000 Prague 8-Liben, Czech Republic E-mail:FVlach@avs.justice.cz

\begin{abstract}
Annotation
The paper describes the solution of the eCALL rescue system in the conditions of the Czech Republic. The use of a VIN decoder type application in the architectural solution of the overall implementation concept is presented and justified. The aim of the solution was to design a robust, safe and reliable PSAP (Public Safety Answering Point) system for providing basic information about vehicles in the event of their accidents or emergencies. The VIN Decoder is basic method of solving demanded targets. The VIN Decoder application is a knowledge-based application about the structure of the VIN (Vehicle Identification Number), which is independent of government information systems. In case of their unavailability or data errors, the VIN decoder is the basic source of information on the technical characteristics of the vehicle. The paper also describes how VIN decoder applications can be used to control the quality of the VIN in government and private critical infrastructure information systems in order to minimize errors in key vehicle object identifiers. The authors, by inspecting various information systems, concluded that an error in the VIN occurs in $8-10 \%$ of identifiers in some government information systems. Therefore, it is necessary to look for ways to reduce this error rate. One of them is the use of a VIN decoder application, especially for critical infrastructure applications. VINdecoder, named VINexpert, is part of eCALL implementation in Czech Republic.
\end{abstract}

\section{Key words}

eCALL, Vehicle Identification Number, VIN decoder, EUCARIS, critical infrastructure, vehicle, emergency. 


\section{Introduction to eCALL project}

One of the main tasks of the European Commission under the name "eSafety" within the flagship program "Intelligent Car" was to launch the so-called eCall project on a European scale two years ago. The general objective of this project is to provide automatic "emergency", electronic ("e") calls for vehicles in the event of an accident or other danger to the vehicle crew to the PSAP (Public Safety Answering Point) operations centers of the integrated rescue system 112 (Matouskova et all, 2015).

Fig. 1. Scheme of the basic idea of the eCALL project.

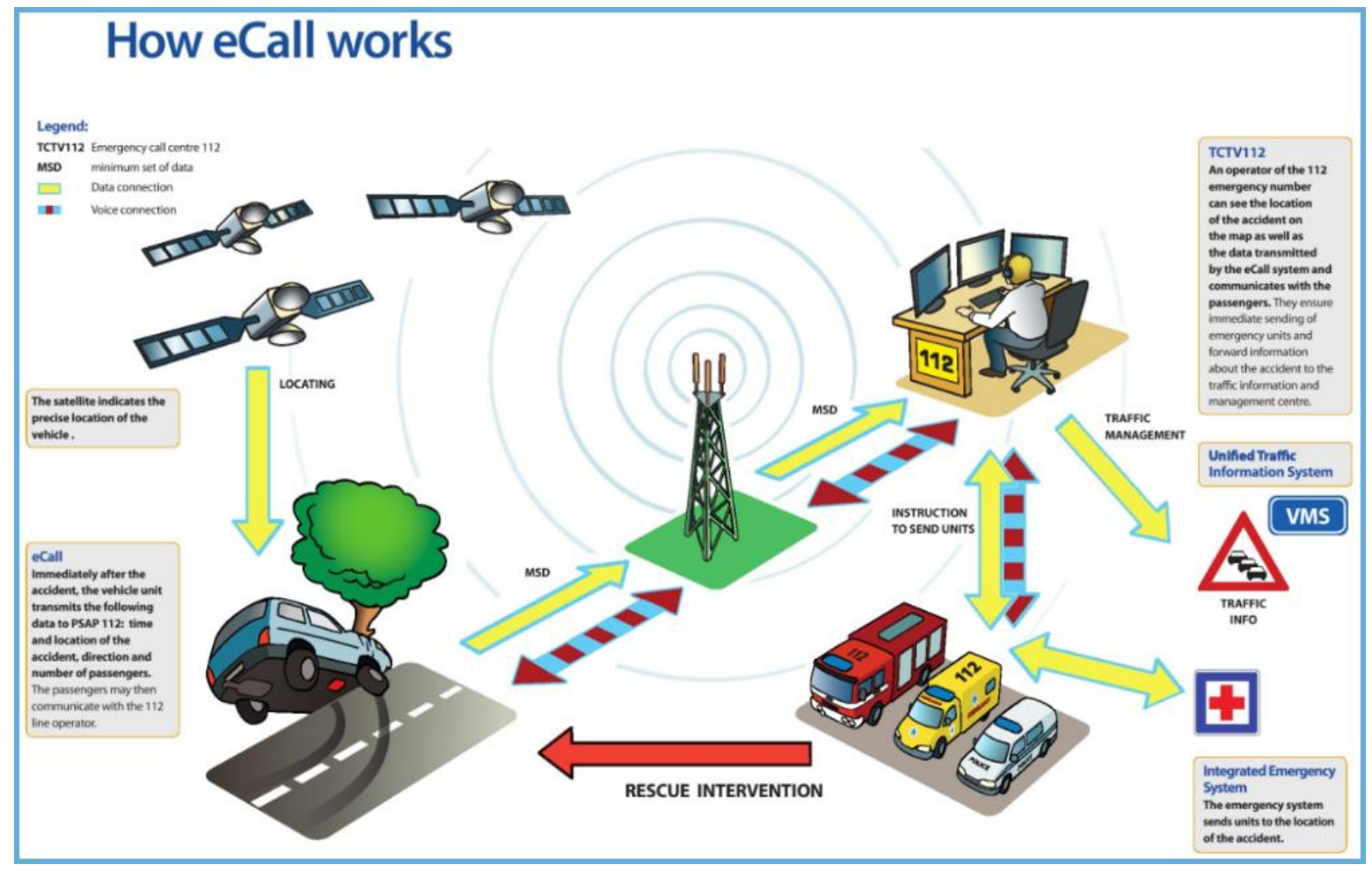

Source: Matouskova et all, 2015.

Each vehicle, homologated after 2018, is located by GPS and basic information about the vehicle in need is transmitted to the PSAP operations center in a uniform telecommunications and data standard binding on the EU through the so-called MSD (Minimum Set of Data) standards, which contains location data and time of the accident, telecommunication parameters and the most basic data about the vehicle (VIN ${ }^{44}$, vehicle category, fuel used, indication of how the device is activated - automatically or manually, number of seat belts fastened at the time of the accident). Each vehicle is also automatically equipped with a voice communication means ("mobile phone"), so that a connection is immediately established between the vehicle in distress and the relevant operations center via emergency number 112. In this way, anyone in the vehicle crew is able to provide accident details (Kubjatko et all, 2018).

In addition to determining the position of the vehicle (which is displayed in the operations center on "digital maps") is calculated, for example, mainly in connection with legacy state (government) information systems, i.e. specifically to national (central) vehicle registers and to EUCARIS technology (European Car and Driving License Information system). This makes additional technical data on the crashed vehicle available, so that the operations officer is immediately informed, for example, what type of vehicle, category and other technical data (dimensions, weights, etc.) it is and it does not matter where the vehicle originates. The available information is then used for optimization, higher efficiency of intervention units (technical equipment, its quantity, specifics, etc.), so the solution of mass, chain

\footnotetext{
${ }^{44}$ Vehicle Identification Number
} 
accidents, accidents at night, when there are no witnesses who would help to call for help hard injured or stressed participants in traffic accidents, etc., is automated, ie the vehicle can "help" to call for adequate rescue when the airbags are activated or after pressing the vehicle's emergency button. Information and communication technologies will also help to eliminate language barriers, where many people on the roads have died in the past simply because they have not been able to say their location (Dirnbach et all, 2020).

One of the decisive factors for the technological solution of the entire eCall project, apart from the technologies of telecommunication and data transmission, special SW, is the vehicle identification according to the VIN (Vehicle Identification Number).

From the VIN identifier it is possible to find out the basic type identification data of the vehicle (make, brand, basic model, type of engine and its volume, power, body shape, year of manufacture, production plant, etc.) (Ahmed, 2018), (Kolitschova et all, 2018).

Fig. 2. Basic architecture of VIN decoder application connection to the eCALL project in the Czech Republic.

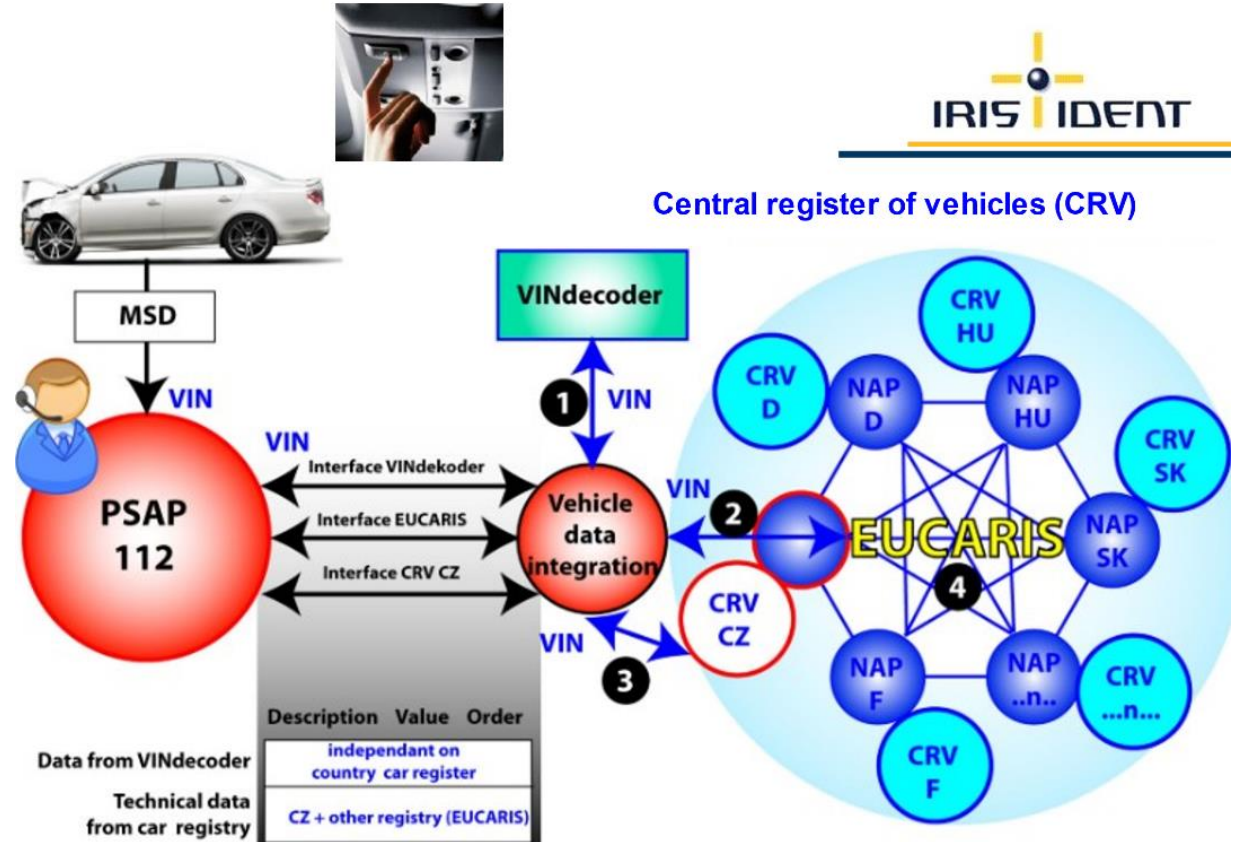

NAP - National access point to EUCARIS

Source: Roman Rak, 2020.

At the same time, VIN in the terminology of computer scientists is the only primary identification key for access to other related vehicle records (Bohm,2020), (Rak et all, 2005), from which other necessary data can be obtained - vehicle registration number, its color (which is a very important visual identification mark when rescue services arrive at the scene), dimensions, weights, volumes of transport spaces (to ensure adequate rescue equipment or the necessary capacities for the safe transfer of transported material from the crashed vehicle and removal from the accident site).

\section{Target and used methods: VIN decoder as a part of Intelligent Transport System eCall in the Czech Republic}

During the discussions, project intentions, initial proposals of the eCall architecture in the Czech Republic, the question of how to transfer as much technical information about the vehicle as possible to the rescue services from the transmitted vehicle unit to the Integrated Rescue System (IRS) operation center was addressed to they had good information for deciding on the composition and technical equipment of the intervening fire brigade. In view of the requirements for a reliable telecommunication 
connection between the vehicle in distress and the operations center, it has been decided that the transmitted message (MSD) must be as short as possible (Boukerche et all, 2017). With "long", dataintensive transmissions, there is a risk of transmission failure in the field. Therefore, it was not possible to include any extensive technical information about the vehicle in this data report.

Fig. 3. Appearance and location of the VIN on vehicles. The VIN is also stored in the eCALL electronic control unit for a vehicle homologated after 2018.

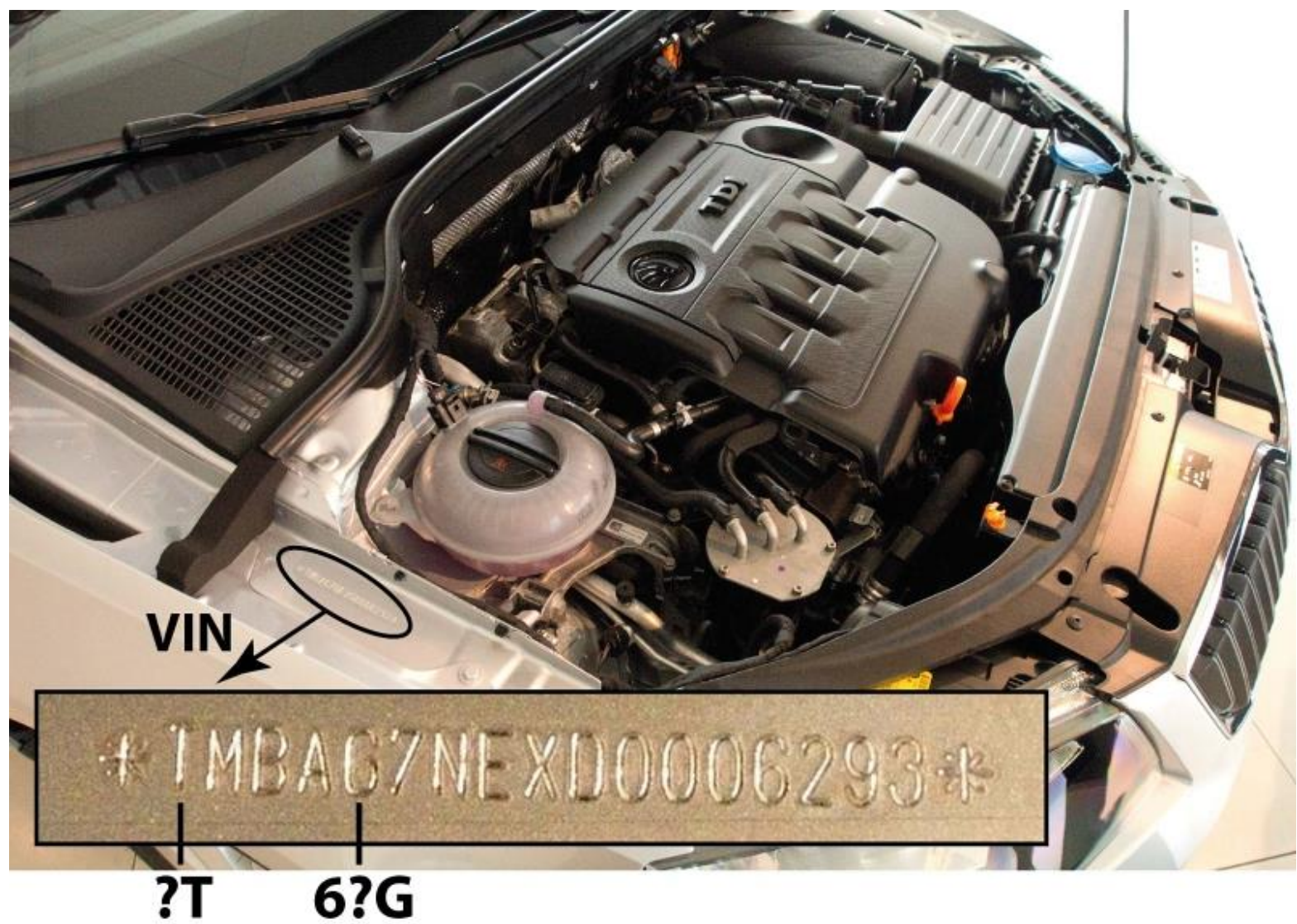

Source: Roman Rak, 2021.

It was decided to incorporate a globally unique VIN (Vehicle Identification Number) into the MSD structure, which on the one hand determines the individual identity of the vehicle, it is possible to read basic information about the vehicle (brand, basic model, category, manufacturer, usually also), body shape and / or engine type, model year, production plant, or other information) and also serves as an interconnection, the so-called database key to various vehicle registers and databases (and further information can be obtained from here) (Dirnbach, 2020). In this way, the condition for reliable data transmission was ensured and at the same time the preconditions for obtaining additional information about the vehicle were created. However, this secondary information is no longer obtained by transmission from the crashed vehicle, resp. vehicles in need (which can be seriously damaged), but from databases that are connected directly to the SW of the operations center. In other words, the source of additional technical-administrative information about the vehicle is not the vehicle itself (it provides primarily to the MSD structure only the VIN, vehicle category and fuel type), but external databases, records, vehicle registers (Rak, 2019), (Rak, 2021).

During the initial considerations of eCall to ensure vehicle identification, it was also necessary to address the international interoperability of eCall, ie obtaining at least basic information about vehicles in need (Casey, 2014). Considerations were still taking place at a time when the EUCARIS interface for the international exchange of vehicle information was not sufficiently publicly known, and the Internet was not entirely common. The only source of information about the vehicle at that time was only the VIN. Therefore, basic vehicle information was required to be extracted from the VIN. 
The method, process of obtaining this information is generally called vindecoding, and the tool itself is a VIN decoder. The term VIN decoder means a SW tool for online decomposition of the VIN structure of individual vehicles, i.e. obtaining basic information about the vehicle from the VIN, which has been entered into its structure by the manufacturer.

Fig. 4. Demonstration of decoding the correct VIN for the Peugeot 5008 vehicle.

\begin{tabular}{|c|c|}
\hline $\begin{array}{l}\text { VF30A5FV8FS097964 } \\
\text { WMI OK Deco ed }(: 0,110 \mathrm{~s}) \\
\text { VF3 Peugeot } 5008(0), \text { categ. }\end{array}$ & 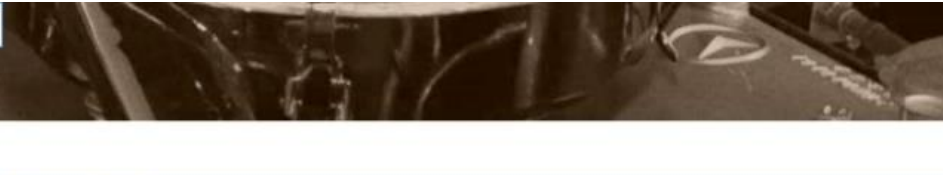 \\
\hline Family of the vehicle & Peugeot 5008 \\
\hline Body & 5 door MPV, 5 seats \\
\hline Engine & EP6CDT / 5 F02 (5FV), 1.6i 156 HP 16V Turbo (1 $598 \mathrm{~cm} 3), 115$ kW @ 6000 RPM, L4, petrol \\
\hline Transmission and emission specification & 6MT / 6MTR: (Stop and Start); Euro 5 \\
\hline Model year & 2015 \\
\hline Assembly plant & Sochaux, France \\
\hline Serial production number & 097964 \\
\hline Production period & $2009-2016$ \\
\hline VF3 & Automobiles Peugeot S.A., Paris, France (passenger car, utility vehicle) \\
\hline Last global homologation & e2*2007/46*0004*20 \\
\hline Destination region & Europe \\
\hline \multicolumn{2}{|l|}{ Remark } \\
\hline MPV & Multi Purpose Vehicle \\
\hline HP & Horse Power \\
\hline $16 \mathrm{~V}$ & 16 valves (total) \\
\hline RPM & Revolutions Per Minute \\
\hline L4 & 4 cylinders in line \\
\hline $6 \mathrm{MT}$ & 6 Manual Transmission \\
\hline 6MTR & 6-speed Manual Robotized gearbox \\
\hline Stop and Start & Stop and Start (engine switching on/off) \\
\hline
\end{tabular}

\section{Interconnection of vehicle application using VIN}

The exchange of vehicle information between all entities of a national and international nature (which work professionally with cars) in information systems (IS) is carried out only through the world-unique VIN (Vehicle Identification Number). It is basically the birth number of the vehicle and during its life (with minimal exceptions) is unchanged, unlike the registration number of the vehicle, which in most European countries changes together with the car owner, in connection with changing the owner's address between territorial units etc. VIN was defined by standards ISO 3779: 2009 (STN ISO 3779: 2013), ISO 3780: 2009 (STN ISO 3780: 2013). These standards are based on standards approved in 1983, ie ISO 3779: 1983 and ISO 3780: 1983.

Current vehicle information checks check information from many reference databases, in which the VIN is usually entered manually. These are national central vehicle registers, information (search) police systems at the national and international level (Schengen, Interpol), information systems of insurance companies, leasing companies, Ministry of Transport, technical or emission control offices, originality or registration checks, executors, services, vehicle dealers, assistance services, etc. In these situations, there is a real danger that the inspection of vehicles from different information sources (with different manual methods of entering VIN) without additional checks on the correctness of VIN, has a potentially high error rate and inspection results may not always correspond to expected reality.

\section{Consequences of VIN errors}

Due to an error in the VIN when searching the reference databases, the required vehicle is not found. But what does this mean in practice? It depends on how we ask how the negative information about the occurrence of the vehicle is methodically treated when querying the vehicle reference database, how we 
work with the returned information, what we expect and whether we are aware of any possible negative impacts.

The information "there is no information about the vehicle of the given VIN" means, for example, that the vehicle was not stolen (not in search records), has no information registered to liquidate the insured event at various insurance companies (it was never crashed), is not execution blocked (not in court records), execution blockages), etc. However, if we entered the wrong VIN without realizing it, it means that the vehicle actually appears in these records and therefore we did not receive the relevant information, on the basis of which an incorrect decision was subsequently made. For example, it was wrong to decide on the purchase of a vehicle, securing a financial lease, transfer to another owner, etc. As a result, a considerable amount of damage occurs, so a certain entity is seriously damaged. A vehicle that has been stolen in another country is registered in the national register, the buyer has bought a stolen vehicle or a vehicle on which a court block is imposed, which can then be confiscated by the police or the insurance company repeatedly pays the insurance fraudster a fraudulent traffic accident, etc.

The fact that the error rate in vehicle records is, for example, $10 \%$, does not in fact mean that the resulting error rate is also $10 \%$. If there is a mutual exchange of information between two entities, resp. their information systems (in which, for example, there is a $10 \%$ error rate), then there are errors "on both sides" and the yield of information already has a $20 \%$ error rate. The error rate adds up. In other words - every fifth vehicle tested has an uncertain, very risky answer!

\section{Conclusion - VIN decoder is one of the very effective tools for increasing the quality of VIN}

During the eCALL solution in the Czech Republic, the VIN decoder was incorporated into the SW architecture of the project solution as one of the key sources of information about the crashed vehicle for the following reasons:

VIN decoding time is less than $1 \mathrm{sec}$. During this time, the operations officer will obtain immediate information on the basic characteristics of the crashed vehicle.

Obtaining information from the VIN via a VIN decoder does not depend on the quality of the connection to other information systems (central vehicle register), which may be unavailable in some critical situations.

There may be errors in the 17-digit VIN in the Central Vehicle Register. In this case, there would be no recovery, finding the vehicle in an emergency. Rescue services would not receive any information about the vehicle and its owner or operator. The probability of such an event is almost $8 \%$.

In the event of a vehicle accident from a European country that is not connected to its national vehicle register via the eCALL module of EUCARIS technology, the rescue services will not receive any information about the crashed vehicle. Currently, only 6 EU countries are involved in the eCALL system from the point of view of international information exchange.

The VIN decoder is application-independent, and in eCALL technology it is able to cooperate with Russian GLONASS-type satellite systems, so that a crashed vehicle using this technology is provided with the same information support as all EU vehicles.

The paper was processed as one of the outputs of "VVÚ No. 245/2019 - Modern technologies in the detection, documentation, evidence and prevention of crime in ensuring public order, safety and fluidity of land transport".

\section{Literature}

AHMED, WAQAS, ARAFAT, SYED YASSER, GUL, NAUMAN, A., (2018), Systematic Review on Vehicle Identification and Classification Techniques, 21st IEEE International Multi-Topic Conference (INMIC), Hamdard Univ, Fac Engn Sci \& Technol, Karachi, Pakistan, ISSN 978-1-5386-7536-6 
BÖHM, K., KUBJATKO, T., PAULA, D., SCHWEIGER, H. G. (2020). New developments on EDR (Event Data Recorder) for automated vehicles. Open Engineering, 10(1), pp. 140146, ISSN: 23915439, DOI: 10.1515/eng-2020-0007

BOUKERCHE, A., SIDDIQUI, A.J, AND MAMMERI, A. (2017). Automated Vehicle Detection and Classification: Models, Methods, and Techniques. ACM Comput. Surv. 50, 5, Article 62 (November 2017), 39 pages. DOI: https://doi.org/10.1145/3107614

CASEY, E., (2004). Digital Evidence and Computer Crime, Academic Press Elsevier, 2nd edition, London, 677 pp., ISBN 0-12-163104-4

DIRNBACH, I., KUBJATKO, T., KOLLA, E., ONDRUŠ, J., ŠARIĆ, Z. (2020). Methodology designed to evaluate accidents at intersection crossings with respect to forensic purposes and transport sustainability. Sustainability (Switzerland), 12(5), 1972 ISSN: 20711050, DOI: 10.3390/su 12051972

KOLITSCHOVA, P, KERBIC P, RAK, R. (2018) Forensic and technical aspects of vehicle identification labels 11th International Scientific and Technical Conference on Automative Safety, Casta Papernicka, Slovakia, Apr 18-20, 2018. Proceedings Paper IEEE Xplore, INSPEC Accession Number: 17823676, DOI: 10.1109/AUTOSAFE.2018.8373340, UT WoS 000435296000046.

F KUBJATKO, T., GÖRTZ, M., MACUROVA, L., BALLAY, M,. (2018). Synergy of forensic and security engineering in relation to the model of deformation energies on vehicles after traffic accidents (Conference Paper) Transport Means - Proceedings of the International ConferenceVolume 2018-October, pp. 1342-1348, 22nd International Scientific on Conference Transport Means 2018; Trasalis - Trakai Resort and SPAGedimino p. 26, Trakai; Lithuania; 3 October 2018 through 5 October 2018; Code 140271,. ISSN: 1822296X

MATOUSKOVA, I., MORAVCIK, L., RAK, R. (2015), eCall - Intelligent Transport System: (legal, technical, information and psychological aspects), Bratislava: Magnet Press, Slovakia, 2015, 683 pp, ISBN 978-80-89169-31-3

RAK, R. (2019). Vehicle Identification Number - anatomy of error occurance (2019), MEIE 2019, $2^{\text {nd }}$ International Conference on Mechanical, Electric and Industrial Engineering, Conference Proceedings, 25-27 May 2019, Hangzhou, China, published on line, 2 September 2019, Journal of Physics: Conference Series (IOP Publishing: JPCS), Volume 1303 (2019) 012146, Online ISSN 1742-6596, Print ISSN 1742-658, doi:10.1088/1742-6596/1303/1/012146, https://iopscience.iop.org/issue/1742$6596 / 1303 / 1$

RAK, R. (2021). Analysis of VIN Errors in Information Systems, Causes, Consequences and Solutions. In: Abdel Wahab M. (eds) Proceedings of 1st International Conference on Structural Damage Modelling and Assessment. Lecture Notes in Civil Engineering, vol 110. Springer, Singapore. ISBN 978-981-159120-4. https://doi.org/10.1007/978-981-15-9121-1_21

RAK, R., MESAROS, M. AND PORADA, V. (2005). The Personality of a Safety Manager. Communications - Scientific letters of the University of Zilina. 7, 3 (Sep. 2005), pp. 12-19, ISSN 1335-4205 
The impact of non-repayable financial contributions on the progressive

development of the infrastructure of the Fire and Rescue Service

DOI: 10.36682/SSS_2021_14

\author{
Col. doc. JUDr. Mgr. Jana Simonova, PhD.
}

\author{
Department of Police Sciences Police Sciences Department \\ Academy of the Police Force in Bratislava Academy of the Police Force \\ $\triangle$ Sklabinská 1, 83517 Bratislava, Slovak republic \\ Email: jana.simonova@akademiapz.sk
}

mjr. Ing. Marian Suja, PhD.

\author{
Department of Public Administration and Crisis Public Administration and Crisis Management \\ Management Department \\ Academy of the Police Force in Bratislava Academy of the Police Force \\ $\triangle$ Sklabinská 1, 83517 Bratislava, Slovak republic \\ Email: marian.suja@akademiapz.sk
}

\begin{abstract}
Annotation
It is financial policy and public finances that can radically indirectly influence the achievement of the purpose pursued by a specific intervention, eg eliminate fire. From the point of view of this contribution, we are interested in examining the direction of current transfers in public administration to the expenditure of public funds in the form of subsidies, which are allocated from the state budget for the area of HaZZ services. The relevance of providing financial resources for the innovation of HaZZ infrastructure has an increasing tendency and is de facto irreplaceable.
\end{abstract}

\title{
Key words
}

Fire and rescue service, subsidy, state budget.

\section{Introduction}

A risk to life, health or property due to accidents, incidents, natural disasters or catastrophes cannot be ruled out. The provision of urgent assistance in endangering life, health or property is in the public interest and is guaranteed by the Constitution of the Slovak Republic. Urgent assistance is inextricably linked with the activities of the rescue services, in particular the Fire and Rescue Service, the Rescue Medical Service, the Mining Rescue Service, the Mountain Rescue Service and the necessary participation of the Police Force. Other legal entities, natural persons - entrepreneurs, voluntary civic associations or institutions with a humanitarian mission also take part in providing assistance, especially in the event of a crisis situation. It took humanity many years to realize that a successful fire fight is possible by associating in societies, in a more efficient systemisation of equipment and armaments and, last but not least, in the issuance of regulations in the field of fire protection. Not only an adequately trained and trained member of the Fire and Rescue Corps, or the so-called volunteer firefighter guarantees the success and effectiveness of the intervention. It is financial policy and public finances that can radically indirectly affect the achievement of the purpose pursued by a specific intervention, such as eliminating fire.

\section{Legal status of the Fire and Rescue Corps}

The basic legal framework for the area in question is Act No. 315/2001 Coll., On the Fire and Rescue Service (hereinafter referred to as "HaZZ"), as amended, which regulates the position and tasks of HaZZ and Act No. 314/2001 Coll. on fire protection, as amended. The said legislation creates conditions for 
ensuring effective preventive measures in preventing fires and effective operational and technical measures for fighting fires and carrying out rescue activities - saving lives and health of people and property. Decree of the Ministry of the Interior of the Slovak Republic 611/2006 Coll.

According to the ISO 8421-8: 1990 standard, we define fire brigades as:

- $\quad$ Private firebrigade: "A fire brigade established and funded within an organization to provide fire protection for its property and personnel."

- $\quad$ Public firebrigade: "A fire brigade established by law to carry out fire-fighting, rescue and other emergency services and, in some cases, fire prevention services in a given community." (STN ISO 8421 8 (92 0002): 2001)

The legal status de lege lata divides the fire brigade as follows:

- $\quad$ fire brigade HaZZ, which is composed of members of HaZZ, / member of HaZZ /

- a company fire brigade, which is composed of employees of a legal entity or a natural person entrepreneur / employee /,

- $\quad$ a racing fire brigade, which is composed of employees of a legal entity or a natural person entrepreneur / member /,

- $\quad$ voluntary fire brigade of the municipality, which is composed of citizens of the municipality / member $/$.

Municipalities are obliged by the Fire Protection Act to set up a voluntary fire brigade (hereinafter "DHZO") to fight fires and carry out rescue work in emergencies in the municipality (or set up a joint fire brigade based on an agreement with the district directorate HaZZ). It does not have to do so if its population is less than 500 or in the case of an agreement with HaZZ or a legal entity or natural person - an entrepreneur based in the municipality, on the basis of which their fire brigades will perform the role of DHZO. ( $\$ 33$ paras. 1 to 4 of Act No. 314/2001 Coll.) When determining the number of employees / members of the fire brigade and its material and technical support, the municipality (city) takes into account local realities, eg size of built-up area, capacity of resources fire-fighting water, natural conditions,

HaZZ is one of the basic rescue services, which has an important place in the hierarchyintegrated rescue system (hereinafter "IRS"). As follows from Act No. 129/2002 Coll., On IRS, and Act No. 315/2001 Coll., On HaZZ, one of the main tasks of HaZZ is to provide assistance in cases of endangerment of life, health of persons and property of legal entities and natural persons. as well as the environment.

In order to ensure the fulfillment of tasks and the performance of individual intervention activities, services are set up in HaZZ, which can be divided into:

- services ensuring the ability to operate and the operation of firefighting equipment and means (machinery, anti-gas, connecting),

- services involved in emergency activities (fire rescue service, flood service).

\section{Impact of non-repayable financial contributions for the development of $\mathrm{HaZZ}$ infrastructure}

The intervention activities of fire brigades in the Slovak Republic consist not only in fighting fires, but also in carrying out other interventions to save the life and health of people, property and the environment. In the last decade, the development of intervention activities of fire brigades is characterized by a significant increase in activities aimed at performing rescue work in natural disasters, road traffic accidents and other accidents, as well as increasing the number of technical interventions of various kinds. Sufficient expertise and resources must be provided to carry out these activities effectively. Closely related to this is the increased need to provide innovative technology for which funds are irreplaceable.

Among the significant transfers of current expenditures through current transfers from the point of view of the application of the redistributive function of public expenditures is their provision in the form of special-purpose, resp. non-earmarked grants and various types of financial contributions. One of their meanings is that they serve to finance the various public needs of the citizens of the state. A certain part 
of subsidies within the budget system is allocated from the state budget to the budgets of individual local governments, specifically for the implementation of regional policy. From the point of view of the contribution in question, we are interested in examining the direction of current transfers in public administration to the expenditure of public funds in the form of subsidies, which are allocated from the state budget for HaZZ services. Special,

The organizational classification of the budget classification offers the identification of budget operations according to the chapters of the state budget and public administration entities. Transfers for general utility services and public benefit purposes are provided from the budget chapter of the Ministry of the Interior of the Slovak Republic. It is mainly non-repayable financial assistance in the form of subsidies on the basis of an application, in our area it will be mainly for the purposes of:

- professional preparation, preventive - educational and vocational - training activities,

- for material - technical support and activities in saving life, health, property and the environment to entities operating in saving life, health, property and the environment in the field of IRS,

- in fire protection sections.

Allocation of funds: (https://www.minv.sk/?dotacie-1)

- for $2011 \quad$ EUR 2083 135,

- for 2012 EUR 2122300 ,

- for 2013 EUR 6,477,906,

- for $2014 \quad$ EUR 6,514,654,

- for $2015 \quad$ EUR 5292800 ,

- for 2016 EUR 5,304,909,

- for 2017 EUR 6,604,712,

- for 2018 EUR 40,394,699,

- for 2019 EUR 7,970,759,

- for $2020 \quad$ EUR 7,970,759.

It is typical for the functioning of subsidies from the point of view of fiscal law that they have an irreversible and non-equivalent character. Thus, subsidies "to a decisive extent finance non-market activities of the state and individual articles of territorial self-governments." (Balko, 2007, p. 11.) As Marková (2007) mentions, According to her, we know two types of subsidies that are provided to municipalities:

- subsidies (contributions), which are allocated in connection with the relationship of the state budget to the municipal budget and subsidies (contributions) for the delegated performance of state administration,

- subsidies of investment and non-investment nature, which cannot be divided in advance into the respective territories and are provided from the chapter General Treasury Report (Marková, 2007, p. 116).

Subsidies belonging to budgetary - legal institutes are provided in the form of a non - repayable financial contribution. In connection with subsidies, it is possible to speak of non-repayable financial assistance, the essence of which is the provision of interest-free funds to legal and natural persons for a specific purpose, which these entities are not obliged to repay. The legislator defines subsidies in Section 8a of Act No. 523/2004 Coll., On Budgetary Rules of Public Administration, as amended. On the other hand, there is also a repayable financial obligation, which is based on the reimbursement of funds provided. There is no legal claim to both forms of financial assistance unless provided for by law. The subsidy may also be provided in connection with European Union funds.

- Mediated form - implementation through a payment or certification body - within the legal definition of EU funds, the Ministry of Finance of the Slovak Republic, which is also a certification body, takes over the role of the paying authority for the Structural Funds and the paying authority for the Cohesion Fund,

- Direct form - implementation through so-called grant schemes, source grants, provided by the EU directly to the final beneficiary (Harušt'áková, 2016, pp. 30 - 31.). EU funds according to 
$\S 2$ letter e) of the Act represent a comprehensive part of public funds, which are provided from the general budget of the EU through the certification body ${ }^{45}$.

On the margin of HaZZ financing, we would like to emphasize first of all that HaZZ also draws funds from EU sources, which represents the so-called additional sources of financing. Their use is identified in the renewal and modernization of infrastructure facilities, material and technical equipment of the flood rescue service, etc.

The most frequent and most dominant form of funds provided from the state budget in the form of subsidies include subsidies defined in accordance with the provisions of $\S 8 \mathrm{a}$ par. 1 of Act No. 523/2004 Coll., On budgetary rules of public administration, as amended, included in the presented block of subsidies provided from public funds categorized as classic subsidies. The classic subsidies also include subsidies provided from the budget chapter of the Ministry of the Interior of the Slovak Republic, regulated by Act No. 526/2010 Coll., On the provision of subsidies. The Ministry of the Interior of the Slovak Republic, in the position of the subsidy provider, determines and defines the range of areas falling within its material scope. From our point of view, it is important to talk especially about the provisions of $\S 2$ par. 1 letter a) and b), according to which funds are provided to support the defined activities of entities belonging to the IRS.

We refer to this area as specialized activities, including in particular the preparation, preventive education activities and training of these entities, as well as the improvement of all material and technical means available to these components, ie. infrastructure area. Funds are earmarked for all activities related primarily to the provision of technical infrastructure of these entities, which includes the procurement of project documentation, construction, acquisition, technical improvement and repairs of buildings and structures of the fire station and armory. In a similar way, funds are reserved for elements of material and technical equipment for the needs of providing firefighting equipment. In accordance with the purposes defined according to $\S 2$ par. 1 letter

The relevance of providing financial resources for the innovation of HaZZ infrastructure has an increasing tendency and is de facto irreplaceable. In the years 2016 to 2018, subsidies allocated in accordance with $\S 3$ a for the needs of the DPO SR provided mainly financing of voluntary fire brigades of municipalities, which used these funds mainly for the improvement of construction infrastructure, material and technical equipment and personal protective equipment. It was mainly about providing work and emergency suits, work shoes, gloves, helmets, hoses, nozzles, pumps, syringes, generators, saws, lighting equipment and axes. They were also used to reimburse the cost of fuel consumption, DHZO, which intervened outside their municipality (Presidium HaZZ, 2017). HaZZ and other fire brigades forming a single unit.

The term "infrastructure of non-commercial rescue services" has its origins in the Regional Operational Program from the programming period 2007-2013, financed from the European Regional Development Fund. The sub-program was one of the basic areas of regional social infrastructure, which also provides the public with fire protection services. The main purpose of this program was a permanent increase not only in the overall quality, but also in the accessibility of services provided by social infrastructure facilities to a wide range of the public. HaZZ services are of a public nature and are funded by national or EU public resources. The public nature of these services presupposes that they will be used for a defined purpose of a public nature, without their use for other gainful activity or investment of entities, which have them at their disposal. Given the irreplaceable nature of emergency services in society, there is a need for due attention and state intervention in this area. This concerns in particular the provision of a high-quality and accessible infrastructure network, in particular the construction of fire brigades, as well as their material and technical equipment (http://www.rokovania.sk/File.aspx/ ViewDocumentHtml / Mater-Dokum-183297? prefixFile $=\mathrm{m}_{-}$). The above-mentioned Regional

\footnotetext{
45 The financial management system of the Structural Funds and the Cohesion Fund for the 2007-2013 programming period defines a certifying authority as a national, regional or local public authority or body designated by a Member State to certify statements of expenditure and payment claims before they are sent to the European Commission.
} 
Operational Program emphasized the need to increase funding for infrastructure development by increasing public funding not only from the state budget but also from the EU budget in the context of guaranteeing greater actionability and success of interventions.

The request and subsequent provision of funds was determined by a defined range of activities that the entity could carry out after obtaining resources:

- activities that resulted in the process of modernization, reconstruction and expansion of existing buildings owned by the entity,

- activities that resulted in the construction of new buildings (exit stations Košice and Trnava),

- activities connected with the provision of their equipment, including information and communication technologies, with the exception of the procurement of means of transport,

- activities associated with the provision of flood rescue service facilities in the conditions of HaZZ

The entities that could obtain the allocated funds include:

- Fire and Rescue Corps,

- municipalities as the founders of DHZO,

- Mountain Rescue Service (Rapporteur: Fire Protection and Rescue Service, 2011, p. 35).

HaZZ modernized or reconstructed 78 fire stations in the amount of $€ 55,657,863.07$ with NFP. DHZO and the Mountain Rescue Service modernized or reconstructed buildings in the amount of $€$ $38,459,783.93$, which were provided to the NFP. Total amount for non-commercial rescue services NFP $94117647 €$. From the point of view of HaZZ, the implementation of the sub-program "non-commercial rescue services" was quite successful in the overall evaluation, because it created the preconditions for subsequent start-up processes that allowed gradual modernization and reconstruction of 78 fire stations owned by HaZZ, which represents about $2 / 3$ of the total number of 116 fire stations that are currently owned by HaZZ (Implementation of HaZZ projects financed from the resources of the Regional Operational Program, 2015, p. 2).

In the framework of the Operational Program "Environmental Quality", implemented by the European Regional Development Fund, a call was announced in 2015 focused on streamlining the management of emergencies affected by climate change, which was included in Priority Axis 3 - Support for risk management, emergency management and resilience. against emergencies affected by climate change. The basic goal was to build risk assessment and early warning systems, strengthen intervention capacities for emergency management at the local and regional level, and support specialized rescue modules. HaZZ focused its attention on the implementation and building of specialized rescue modules, while the HaZZ Presidium in the position of the organizational unit of the Ministry of the Interior of the Slovak Republic ensures the implementation of three projects.

From the point of view of the impact of non-repayable funds on the development of infrastructure, we see, for example, an air fire extinguishing module using helicopters with a total value of almost $€ 47$ million. It will include the provision of 5 pieces of technological equipment to eliminate risks related to climate change, such as helicopters and a flying platform for air monitoring of the situation at the scene. The aim is to provide technical and technological equipment and appropriate training of HaZZ members (training and education) with subsequent certification of the module and its inclusion in the CECIS database. It is through this module that the effective protection of life and health of citizens, their property, protection of social and economic infrastructure, as well as protection of the environment will be ensured. The secondary impact is identifiable in increasing the protection of members of the intervening units and in fighting forest fires more efficiently and quickly. The second example of the operational program in question is the establishment of technical and institutional support through the establishment of a temporary emergency camp (ETC), through which the emergency accommodation of persons affected by the consequences of an adverse event will be provided. The module will include the procurement of 132 facilities to eliminate risks related to climate change, in particular containers containing everything needed for the construction and operation of the camp and automotive equipment for the transport of containers and HaZZ service personnel. The last of the mentioned modules is the socalled GFFF-V (ground firefighting of forest fires), whose development of the infrastructure will be 
focused on the procurement of 25 pieces of specialized automotive technology to eliminate risks related to climate change, such as high-capacity and off-road tanker car sprayers, or special vehicles with high off-road capacity. This technique, together with the training of HaZZ members, will provide the Slovak Republic with such capacities that will enable it to provide assistance to any EU Member State in the event of a crisis situation (www.minv.sk).

\section{Conclusion}

The requirement to ensure a sufficient level of protection in relation to every citizen of a given state puts him in a position in which he has to face various challenges. The above also applies in the security environment of the Slovak Republic, which is exposed to security threats of various kinds. It is up to the state to deal with these risks, which pose a security threat to its citizens, then. These aspects will subsequently be reflected in the initiative of the state to support those components whose task is to ensure the required level of protection of the population of this state.

The level of fulfillment of basic tasks and provision of services of these rescue units, and thus the level of protection of individual citizens will depend primarily on the quality of their personnel equipment and material and technical support. In this regard, it is a necessary requirement for the state to ensure for the above specific activities the optimal use of funds for the progressive development of the HaZZ infrastructure. As the modus operandi, climatic conditions change dynamically, the HaZZ infrastructure needs to be innovated similarly and promptly.

An important finding was also the fact that the period from 2016 shows a tendency to increase the volume of funding in the form of non-repayable financial contributions, earmarked primarily for DHZO. At the same time, we came to the conclusion that the activities of the state leading to the mentioned processes were an encouraging stimulus for the municipalities to meet all the requirements and subsequently obtain these funds. In view of all the above facts and findings, we have come to the conclusion that the overriding interest of the state and its representatives in relation to its overall security should be to pay sufficient attention to the development of the rescue system, which is a guarantee of its activities. These visions should be reflected not only in HaZZ as a whole, but also in relation to DHZO, which are becoming increasingly important over time.

\section{Literature}

BALKO, L., (2007). Expenditure policy and strategy of public administration expenditures with an emphasis on financing social needs. In: Meeting of financial lawyers. Bratislava: Akadémia Policajného zboru, 2007. pp. 9-23. ISBN 978-80-8054-410-2.

HARUŠŤÁKOVÁ, I., (2016). Act on Budgetary Rules of Public Administration: Commentary. Wolters Kluwer. 368 pp. ISBN: 978-80-8168-436-4.

MARKOVÁ, H., (2007). Contributions and subsidies in the financial management of municipalities. In: Meeting of financial lawyers. Bratislava: Akadémia Policajného zboru, 2007. pp. 115-121. ISBN 97880-8054-410-2.

Ministry of Transport, Construction and Regional Development. Regional Operational Program In: Negotiations of the Government of the Slovak Republic [cit. January 22, 2019]. Available on the Internet: 183297?prefixFile $=m_{-}$. http://www.rokovania.sk/File.aspx/ViewDocumentHtml/Mater-Dokum-

Ministry of the Interior of the Slovak Republic Presidium of the Fire and Rescue Corps, (2011). Rapporteur: Fire Protection and Rescue Service, p. 35. Volume XLI, ISSN 1335-9975.

Ministry of the Interior of the Slovak Republic Presidium of the Fire and Rescue Corps, (2015). Implementation of Fire and Rescue Corps projects financed from the resources of the Regional Operational Program, p. 2.

Ministry of the Interior of the Slovak Republic, (2018). program In: Ministry of the Interior of the Slovak Republic [cit. February 13, 2019]. Available on the Internet: https://www.minv.sk/?dotacie-1. 
Presidium of the Fire and Rescue Corps. (2017). Commentary on the settlement of financial relations with the state budget for the years 2015-2017, p. 1.

STN ISO 8421-8 (92 0002): 2001, Fire protection. Dictionary. Part 8: Deadlines for fire-fighting, rescue services and handling of hazardous materials.

Decree of the Ministry of the Interior of the Slovak Republic 611/2006 Coll., On fire brigades, as amended.

Act No. 129/2002 Coll., On the integrated rescue system, as amended.

Act No. 314/2001 Coll., On fire protection, as amended.

Act No. 315/2001 Coll., on the Fire and Rescue Corps, as amended

Act No. 523/2004 Coll., on budgetary rules of public administration, as amended.

Act No. 526/2010 Coll., On the provision of subsidies within the competence of the Ministry of the Interior of the Slovak Republic, as amended. 
DOI: 10.36682/SSS_2021_15

Ing. Vladimir Sulc, Ph.D.

\author{
Department, institute Department of Security and Law. \\ University Ambis University, as \\ $\triangle$ Lindnerova 575/1, 180 00, Prague, Czech Republic \\ Email:vladimir.sulc@ambis.cz.
}

\begin{abstract}
Annotation
The paper presents not only the latest trends in cyber security, but also describes what the coming period in the field of cyber threats, attacks and protection options will bring. Because of the current COVID19 pandemic, we are beginning a decade of profound changes in the physical world and cyberspace. People will be socially distant and will make more use of virtual space to communicate and build relationships. The protection of individuals, businesses and organizations in the use of cyberspace will tend to move from traditional network and information security to a broader concept encompassing content and services over the next decade. So what do individuals, businesses and organizations have to worry about in the field of cyber security and what to look out for? The aim of the paper is to answer these questions with scientific methods and to analyze and systematically express the latest trends in cyber security.
\end{abstract}

\title{
Key words
}

The latest trends, cyber security, cyber threats, cyber attacks.

\section{Introduction}

The new trends we encounter in the field of corporate IT have their pros and cons. It always depends on the angle of view. The financial department will have a different opinion, which, for example, can optimize financial costs by migrating IT infrastructure to the cloud, while the department responsible for IT security will have the opposite view. New challenges also represent new security threats that need to be covered and eliminated. From time immemorial, corporate security has been based on four cornerstones of legislative, organizational and technical measures, which complement a crucial area that needs to be focused on, and that is the human factor (Shackelford, Russel, Kuehn, 2016). Many studies and security audits have long shown that the human factor is the weakest link in any corporate cyber security strategy. According to Kaspersky's "The Human Factor in IT Security ..." report (2017), more than half of companies fear security breaches coming from within. According to the report, employees accounted for $46 \%$ of all cyber security incidents that companies were forced to face last year. Therefore, we can practically do without a detailed overview of what is happening inside the perimeter in the future.

As part of legislative measures, the situation is relatively legible for selected companies. The Cyber Security Act clearly states what legal requirements I have to adopt as a company falling into one of the listed categories $(\$ 3,205 / 2017$ Coll.), And what appropriate steps I will have to address in order to prevent security risks (see Decree No. 82 / 2018 Coll.). If we want to implement cyber security in any organization, we must first clarify what we want to protect and why we want to protect it. For companies working with information, such as government, IT services, software companies or telecommunications operators, it is appropriate to precisely define the scope and boundaries of the information security management system and apply the ISO 27001 standard, which is aimed at managing the security of information trust for employees. processes, IT systems, but it also touches on corporate strategy (Doucek, 2011). Within the framework of legislative measures, companies most often make mistakes in the ordinary handling of sensitive information (Polčák, Harašta, Stupka, 2016). 
Typical examples are documents of a sensitive nature left on the table and within reach of everyone around, or documents forgotten elsewhere, such as removable media such as USB flash, etc. With the advent of GDPR, the most common offenses also included insufficient security and handling of information and personal data in cyberspace.

\section{Who is responsible for cyber security?}

If we want to face new security challenges, we need to get rid of the most common misdemeanor in terms of organizational measures - when asked who in the company is responsible for IT security, we often learn from management that the IT department. It is a mistake that this is implicitly assumed, without being explicitly stated. If it is to be an IT department, someone needs to be dedicated to IT security there full-time and with sufficient powers. Likewise, the importance of other organizational measures in the form of corporate guidelines, procedures, or methodologies is often underestimated (Kane, 2019). It is also good to mention the need for risk analysis, crisis scenarios or regular backup testing, etc. Decree No. 82/2018 Coll. gives a clear idea of what organizational measures a company should take: "Many organizations back up data, but no longer operating systems. Not to mention the recovery test.

\section{It will be increasingly important to know what is going on in the network.}

A large amount of security resources are still devoted to technical security against external attacks, often ignoring threats coming from within the organization. "Companies are investing $90 \%$ of their security budget in perimeter protection, although only $25 \%$ of attacks are directed there," said Newe (2016), director of systems engineering at F5 Networks. It is therefore very important to know what is happening inside the network. Today, the analysis of data flows, so-called flow data, is best used for this (Shostack, 2014). This technology for modern network traffic monitoring provides detailed statistics on network communication, ie who communicates with whom, when, for how long and often, how much data has been transferred, on which ports the communication takes place, what protocols it uses and other TCP / IP information. communication from layers L3 - L4 (Graham, Howard, Olson, 2011).

\section{Beware of threats using encrypted communication.}

Paradoxically, the growing volume of encrypted communication represents another security challenge for corporate security. The encryption created a gray zone with unlimited space for attackers. Dangerous malware can successfully hide its activities here. Whether in the initial phase when it needs to download additional malicious code or in subsequent communication with the control server (Kane, 2019). Therefore, the importance of tools that can analyze encrypted communication will grow. Particularly suitable are those that solve the situation in a non-invasive and passive way from the point of view of the network. By analyzing metadata from layers L2, L3 and L4, and using probes, they can extract other necessary information for SSL / TLS traffic from application layer L7 (Graham, Howard, Olson, 2011). For example, they will help with the management of certificates, warn of security risks associated with a short encryption key and more.

\section{The cloud is the biggest challenge of the future.}

The number of companies deciding to move their corporate infrastructure to the cloud is growing every year (Trend Micro, 2019). The cloud environment usually brings companies cost optimization, greater flexibility, scalability, as well as new access options. However, the truth is that migrating to the cloud brings with it entirely new challenges for network and application monitoring and diagnostics, because the existing tools we are used to are simply not able to provide that. It is therefore necessary to consider a new approach and methods that will help us regain lost confidence and visibility even in a hybrid cloud environment.

The reasons why traditional monitoring approaches fail are obvious. The main problem is the lack of access to information from the L2 network layer in the public cloud environment. Traditional noninvasive approaches using the SPAN port do not work here and statistics from active network elements are also missing (Graham, Howard, Olson, 2011). Therefore, these cloud blinds may seem to make it impossible to analyze critical data that addresses security threats and performance issues. So far, there 
are few companies in the world that can cope with this limitation and offer a central view of all network traffic data consolidated across infrastructure. They mainly use flexible network probes, which enable different ways of deployment across environments such as on-premise, private cloud or public cloud, and at the same time provide identical data from these different environments.

These ways are currently used to ensure visibility in the public cloud. One of them is an agent solution installed on monitored servers - so-called Virtual taping. It intercepts communication between virtual machines and delivers packets to third-party monitoring tools. Another of them is port mirroring at the L3 level and delivery of a copy of network traffic to monitoring tools via the so-called GRE tunnel. Some solutions can also terminate the ERSPAN / GRE tunnel and do not need any interlayer. Another approach is the ability of platforms to directly deliver the necessary data from the public cloud environment to monitoring tools (European Union for Network and Information Security, 2015).

The most advanced way to ensure visibility in the public cloud is the native means of accessing network traffic provided directly by the platform. Microsoft Azure is now the furthest in this field with a technology called vTAP. It allows to transfer a copy of data traffic between virtual machines, including communication within the VM (so-called east-west traffic) to selected monitoring tools. Virtual TAP eliminates blind spots in a virtual network and allows you to analyze important data related to security and performance issues (Shostack, 2014).

\section{Internet of Things and SCADA / ICS.}

In the future, the operators of industrial networks and SCADA / ICS systems and the world around the Internet of Things, for example within Industry 4.0, will not do without the analysis of data flows. The transition to traditional network communication of previously strictly separate systems and their interconnection with commercial IT exposes this environment to a great security risk and opens up new opportunities for attackers. The consequences of a cyber attack on SCADA systems can often be devastating for society, as demonstrated, for example, by the Industroyer malware in 2016 during an attack on Ukraine's energy network. SCADA / ICS systems have the advantage of more or less stable data flows (Kaspersky, 2019).

Thanks to this, it is possible to quickly detect data and react to any anomalies using suitable monitoring technology working with data flows. It is the increased demands on security that are the reason why major manufacturers of monitoring tools are also interested in this environment. For example, one of the best known in its latest version of its solution offers native visibility to the IoT environment and industrial systems, represented by the CoAP and IEC 104 protocols (Kane, 2019).

\section{Employees will continue to be the target of attackers.}

The human factor has been, is and always will be a major weakness in corporate IT security. Especially in the case of targeted attacks, it is probably the weakest place in the overall cyber security of companies. Attackers like to use the methods of phishing and social engineering (Šulc, 2018), which will not change in the coming years. The risk of human error is highest, especially for smaller companies that lack a cyber security expert. In most cases, this is directly related to the lack of information and training of employees. The study mentioned in the introduction by Kaspersky (2017) pointed out that only $12 \%$ of employees know the rules for the company's cyber security. New trends in the form of BYOD and corporate laptops (Trend Micro, 2019) only deepen this weakness.

\section{Development trends in the field of cyber security.}

Anect has published a brief summary of cyber security trends for the coming period (IT Systems Magazine, 2019). According to her, what will the coming year bring in terms of cyber threats, attacks and protection options? What should companies be afraid of and what should they be careful about?

a) Enhanced phishing and social engineering.

Data obtained from leaks and combined with other publicly and non-publicly available information will become an input for artificial intelligence, language recognition and will lead to a new wave of fully 
automated and highly effective phishing attacks based on much more sophisticated social engineering (Trend Micro, 2019).

b) Cyber-terrorist attacks target more infrastructure.

With "crimeware-as-a-service", it will become easier and more sophisticated to attack than with ransomware, which has been essentially the most popular and effective tool for hackers to date. The ability to disable the operation of companies, but also public infrastructure, will be one of the fundamental goals that cyberterrorist organizations will want to achieve (Smejkal, 2018). Attacks directly supported by some states will not be an exception. An attack on service providers, whether hardware or software (Trend Micro, 2019), will also be a popular and very dangerous tool, as fundamentally weak links will still appear there.

c) Cloud $=$ a tool for harm and benefit.

There will be no radical changes in the area of cloud solutions either. However, the cloud is now in many forms part of business and among end users (Shackelford, Russel, Kuehn, 2016), so in the future there will be an increasing emphasis on cloud and cloud application security, secure and audited data storage and management, and efficient management of all deployed clouds that companies (but really individuals) have. As massive password leaks continue to occur after hackers, it will be even more important to protect everything consistently and correctly. Problems with the use of the cloud will be exacerbated by the increasingly frequent transition to agile methods of development and immediate deployment in production (so-called Dev-Ops) and the use of container technologies (Trend Micro, 2019).

d) Login with a password is still the least suitable alternative.

The security of online accounts and services based on the classic login using a username and password has been a major security issue for the last few years. Although the following period will not bring an end to passwords on a larger scale, it is a good reason to deploy two-factor authentication and other more advanced login methods, including biometric methods or cryptographically based hardware keys (Šulc, 2018).

e) Artificial intelligence on the good and bad sides.

Artificial intelligence (abbreviated AI), mainly in the form of machine (ML) and in-depth learning, will help both the good and the bad. While this is not hot news, however, with increasing computing capacity and better availability of the necessary software and hardware, virus and malware creators will be even more looking for help in AI / ML protection against detection (Trend Micro, 2019). All protection systems will behave in the same way. It will typically be a game of cat and mouse. It will also help indepth learning and more efficient ways of analyzing large amounts of data, which can again be used for both good and bad purposes. Also important is the fact that these technologies will significantly strengthen efforts for payment card fraud, online payments and online advertising (Smejkal, 2018).

f) A never-ending series of massive leaks of passwords and personal data.

It is certain that in the coming years there will be further leaks of hundreds of millions of passwords and user data, including complete data on credit cards and other data, which will be misused for identity theft and phishing attacks. To find a cautious example, just look at the end of 2018, when there was a data leak from Marriott, which was also accompanied by the fact that hackers in the systems operated undisturbed for up to 4 years (Kaspersky, 2019).

g) Attacks on IoT devices, infrastructure and transmitted data.

In the coming years, attacks on the Internet of Things (IoT), a platform based essentially on inappropriate and misplaced protocols, will also intensify. The classic attacks on infrastructures, attacks on domestic and corporate routers will also continue. There will also be new creative ways to use the infected devices for attacks on transmitted data. An ever faster infrastructure will facilitate larger DDoS attacks (Trend Micro, 2019).

h) Privacy will still be the focus, but there will be no change. 
After a series of scandals connected mainly with Facebook and unprotectable privacy (Kaspersky, 2019), the effort to return users control of their information will be very strong in the coming years, but it will not have any major results. The European GDPR regulation, which came into force in May 2018, will make it possible to detect and punish some fundamental sinners, but most of them will remain undetected for several more years.

i) The arrival of $5 \mathrm{G}$ will open a new field for attacks.

Extremely fast mobile networks will make hacker attacks even easier in terms of speed and capacity. However, the ever-growing share of 5G (and 4G) devices in a fixed form, ie the gradual replacement of fixed data lines (Internet connections), will be crucial. The number of 5G IoT devices will also increase, moving from behind Wi-Fi routers to a directly attackable position (Trend Micro, 2019).

j) Legislation and regulation will lag behind again.

Efforts to correct privacy, data leaks, and other issues described above through legislation or regulation will fail. The work with regard to the existence of a global environment in which it is not possible to achieve agreement and unity, but also by the fact that the time from the design of adjustments to their actual deployment is so long that the originally solved problems and conditions will no longer apply. So it looks like another bad period in terms of information and cyber security. At the same time, reducing risk is still only a matter of complying with the basic rules, which include in particular (Kostopoulos, 2013):

- have order in your own network (know its content, how vulnerable the individual elements are and be able to remove the most critical holes in time);

- $\quad$ keep order in your own users (train and train all users, manage administrators, etc.);

- $\quad$ keep your data in order (know which ones are the most critical and where they are located);

- common sense (constant assessment of changing risks).

\section{Conclusion}

Cybercrime and legislation of the Czech Republic and the EU bring the need to design a cyber security architecture as a large-scale active, sophisticated solution, which is not limited to passive responses to possible cyber attacks, but actively discourages potential attackers from their offensive efforts and intentions (Smejkal, 2018). The basic principle of this solution is to obtain a detailed overview of events in its internal network and events on perimeters as interfaces through which the internal network communicates with the external environment. Another principle is the need for quality evaluation of cyber security events and timely response to them at the time of the occurrence of an anomaly that would mean a cyber security incident. The ever-increasing dependence on the cyber environment is still greatly underestimated and downplayed.

In this paper, I have briefly expressed the essential ideas and conclusions of my research work in the field of cyber security and presented the latest trends in this field. The contribution by scientific methods not only presents the latest trends in cyber security, but also provides answers to the questions of what individuals, businesses and organizations in the field of cyber security should be afraid of and what to look out for? The aim of this paper was not only to answer these questions with scientific methods and analyze and systematically express the latest trends in cyber security, but also to expand the information base on cyber security issues and increase public security awareness.

\section{Literature}

BAYUK, JL, Healey, J., Rohmeyer, P., Sachs, MH, Schmidt, J., Weiss, J., (2012). Cyber security policy guidebook. Hoboken. NJ: John Wiley. ISBN 978-1-118-02780-6.

DOUCEK, P., (2011). Information security management. Prague: Professional Publishing. ISBN 97880-7431-050-8.

European union agency for network and information security, (2015). Cyber Security Information Sharing: An Overview of Regulatory and Non-regulatory Approaches. ISBN 978-92-9204-131-1. 
Evasive Threats, Pervasive Effect.[online]. Trend Micro, 2019 [cit. 2021-09-15]. Available from WWW:http://www.trendmicro.com/vinfo/us/security/research-and-analysis/threatreports/roundup/evasive-threats-pervasive-effects

GRAHAM, J., HOWARD, R., OLSON, R., (2011). Cyber Security Essentials. CRC Press. ISBN 9781439851234.

IT threat evolution Q3 2019 statistics. [online]. Kaspersky, 2019 [cit. 2021-09-15]. Available from WWW:http://securelist.com/it-threat-evolution-q3-2019-statistics/95269

KANE, A., (2019). New challenges for enterprise security. [online]. IT Systems Magazine, 2019 [cited. 2021-09-15]. CCB spol. s ro ISSN 1802-615X. Available from WWW: https://m.systemonline.cz/itsecurity/nove-vyzvy-pro-zajisteni-podnikove-bezpecnosti.htm

KOSTOPOULOS, GK, (2013). Cyberspace and cybersecurity. Boca Raton, Fl .: CRC Press. ISBN 14665-0133-2.

NEWE, G., (2016). What The WADA Hack Proves About Today's Threat Landscape. [online]. DARKReading, 2016 [cit. 2021-09-15]. Available from WWW: https://www.darkreading.com/attacksbreaches/what-the-wada-hack-proves-about-today-s-threat-landscape

POLČÁK, R., HARAŠTA, J., STUPKA, V., (2016). Legal issues of cyber security. Brno: Masaryk University. ISBN 978-80-210-8426-1.

SHACKELFORD, SJ, RUSSEL, S., KUEHN, A., (2016). Unpacking the International Law on Cybersecurity Due Diligence: Lessons from the Public and Private Sectors. Chicago Journal of International Law. 2016, 17 (1). ISSN 1529-0816.

SHOSTACK, A., (2014). Threat modeling: Designing for security. John Wiley \& Sons. ISBN 978-1118-80999-0.

SINGER, PW, FRIEDMAN, A., (2013). Cybersecurity: What Everyone Needs to Know. USA: Oxford University Press. ISBN 0199918112.

SMEJKAL, V., (2018). Cybercrime. Pilsen: Ales Cenek. ISBN 978-80-7380-501-2.

ŠULC, V., (2018). Cyber security. Pilsen: Ales Cenek. ISBN 978-80-7380-737-5.

The Human Factor in IT Security: How Employees are Making Businesses Vulnerable from Within.[online]. Kaspersky, 2017 [cit. 2021-09-15]. Available from WWW: https://www.kaspersky.com/blog/the-human-factor-in-it-security/

TOP 10 - What will 2019 bring in the field of cyber security?[online]. IT Systems Magazine, 2019 [cited. 2021-09-15]. CCB spol. s ro ISSN 1802-615X. Available from WWW: https://www.systemonline.cz/it-security/top-10-co-prinese-rok-2019-v-oblasti-kybernetickebezpecnosti.htm

Decree No. 82/2018 Coll., Decree on security measures, cyber security incidents, reactive measures, requirements for filing in the field of cyber security and data disposal (Decree on cyber security).

Act No. 205/2017 Coll., Amending Act No. 181/2014 Coll., On cyber security. 
College of European and Regional Studies Department of Law and Security Studies

INTERNATIONAL CONFERENCE SAFE AND SECURE SOCIETY 2021

\author{
Edited by \\ Štěpán Kavan
}

Publisher:

College of European and Regional Studies Žižkova tř. 6, České Budějovice

Czech Republic, 2021

www.icsss.eu

DOI DOI: 10.36682/SSS_2021

ISBN 978-80-7556-097-1

ISSN 2533-6223 